
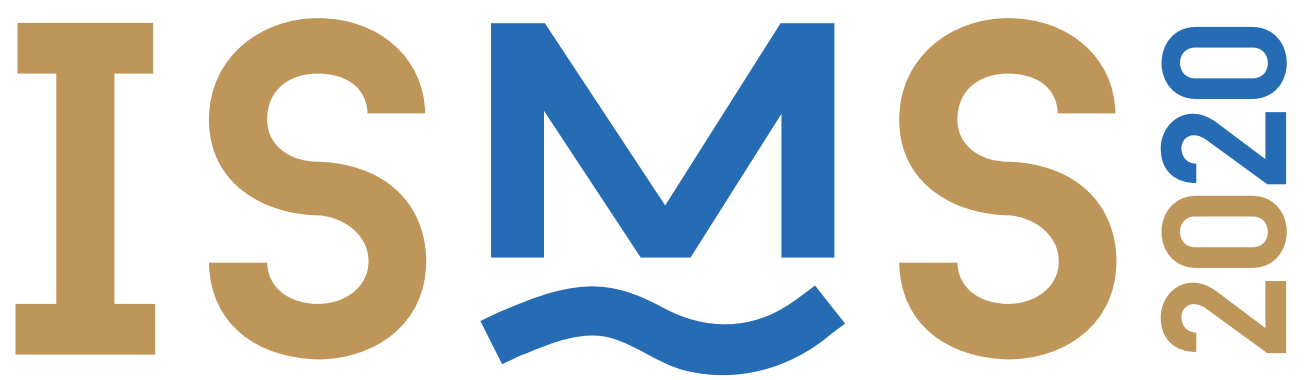

VII INTERNATIONAL SYMPOSIUM ON MARINE SCIENCES

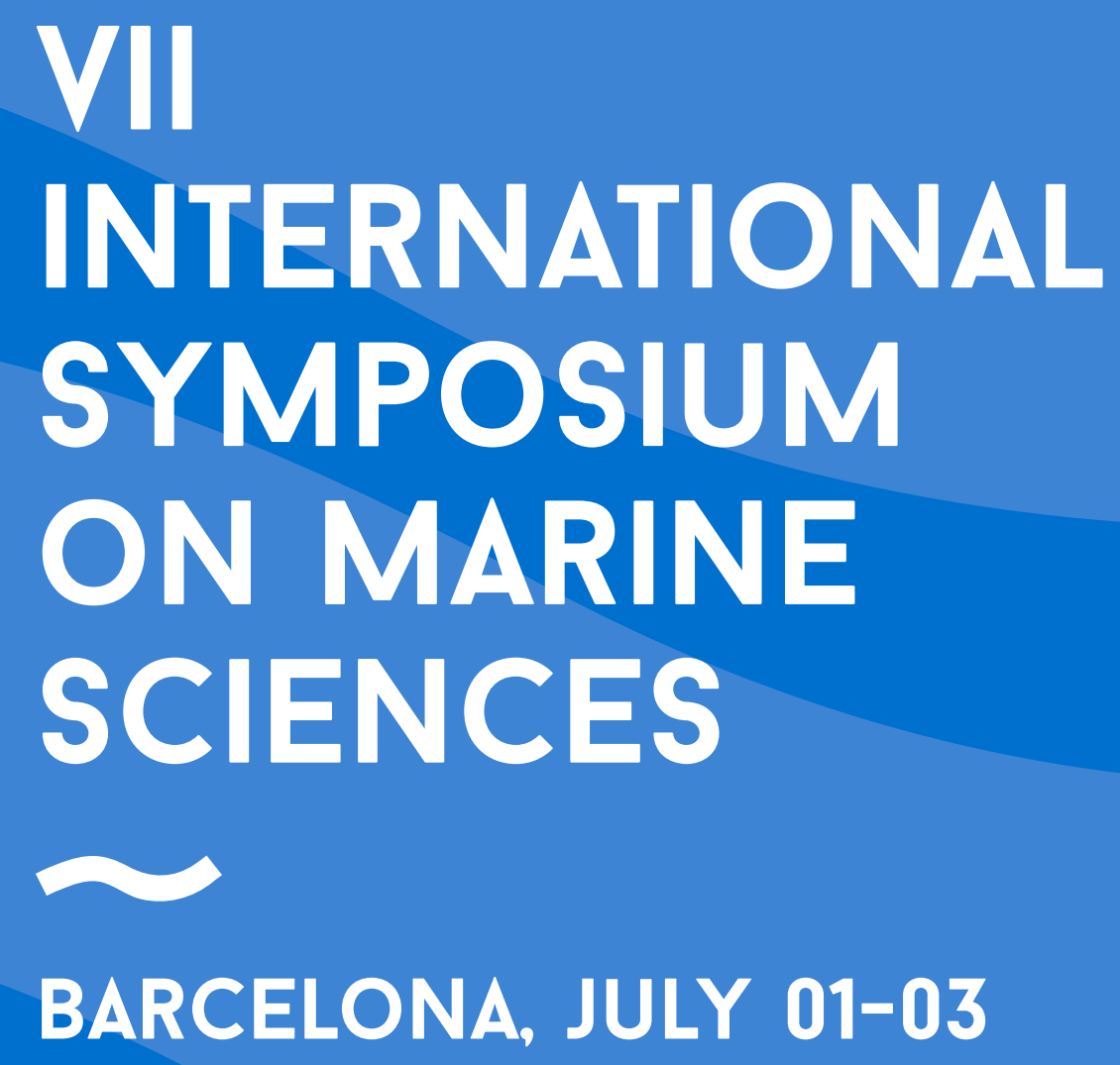




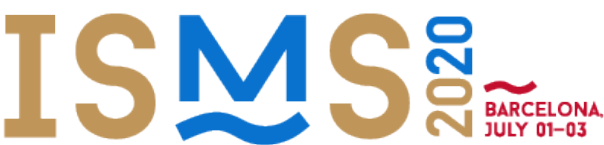 \\ VII INTERNATIONAL SYMPOSIUM ON MARINE SCIENCES}

\section{Coordinating Organizing Committee:}

Ana María Blázquez Morilla, Carolina Mendiguchía, Naría Esther Torres Padrón, Miquel Canals Artigas, Miguel Ángel Nombela, Carlos Valle, Ana de Luis Margarit.

\section{Local Organizing Commitee:}

Miquel Canals Artigas, Criz Palacín, Javier Romero, Marta Coll, Josep Lluís Pelegrí, Agustín SánchezArcilla, Manuel Espino, Leopoldo D. Pena, Anna Sánchez-Vidal, Galderic, Lastras, Cristina Linares, Lluis Cardona.

\section{Scientific Commitee:}

Jacopo Aguzzi, Jesús Forja Pajares, Sergio Molina, Teresa Alcoverro, Eugenio Fraile Nuez, Theodore Train Packard, Irene Alejo Flores, Ibon Galparsoro, Albert Palanques, Xosé Antón Álvarez Salgado, José Rafael García-March, Marta Pascual, David Amblas, Jordi García Orellana, Carles Pedrós-Alió, Javier Arístegui Ruiz, Josep Ma Gili, Yoana Del Pilar Ruso, Jesús María Arrieta López Uralde, Jorge Guillén, Laura Prieto Gálvez, José Francisco Baeza Carratalá, Francisca Giménez Casalduero, Fran Ramil, Javier Benabente González, Milagrosa (May) Gómez, Alfonso A. Ramos Esplá, Ana María Blázquez Morilla, Damián, Gomis, Yassine Ramzi Sghaier, Miguel Bruno Mejías, Melchor González Dávila, Josep Raventós, Isabel Cacho, José Carlos González Mejía, Ángel Rodríguez Santana, Antoni M. Calafat, Joan Grimalt, Joan A. SánchezCabeza, Jerónimo Chirivella, Ángel Guerra, Amanda Sancho, Marta Coll, Ignacio Hernández Carrero, Magdalena Santana Casiano, Joan Baptista Company, Santiago Hernández León, Carlos Sanz, Hugo Corbí, Francisco Javier Hernández-Molina, José Tena Medialdea, Roberto Danovaro, Serge Heussner, Antonio Tovar Sánchez, Fidel Echeverría Navas, José A. Jiménez, Jesús S. Troncoso, Emanuela Fanelli, Vitor Magalhaes, Xavier Turón, Fiz Fernández, Rafael Mañanes Salinas, Juan Tomás Vázquez Garrido, María del Carmen Fernández Puga, Emilio Marañón, Inmaculada Varó, Luis Miguel Fernández Salas, Jacobo Martín, Pedro Vélez Belchí, Aitor Forcada Almarcha, Pere Masqué, Nardo Vicente.

\section{Editors:}

Miquel Canals, Lluís Cardona, Galderic Lastras, Cristina Linares, Cruz Palacín, Leopoldo D. Pena, Javier Romero y Anna Sánchez-Vidal.

Abstracts Volume VII International Symposium on Marine Sciences, July 2020 ISBN: 978-84-120734-7-8

Linckia 


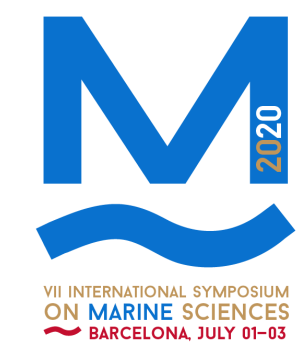

\section{INDEX}

\section{ORAL COMMUNICATIONS}

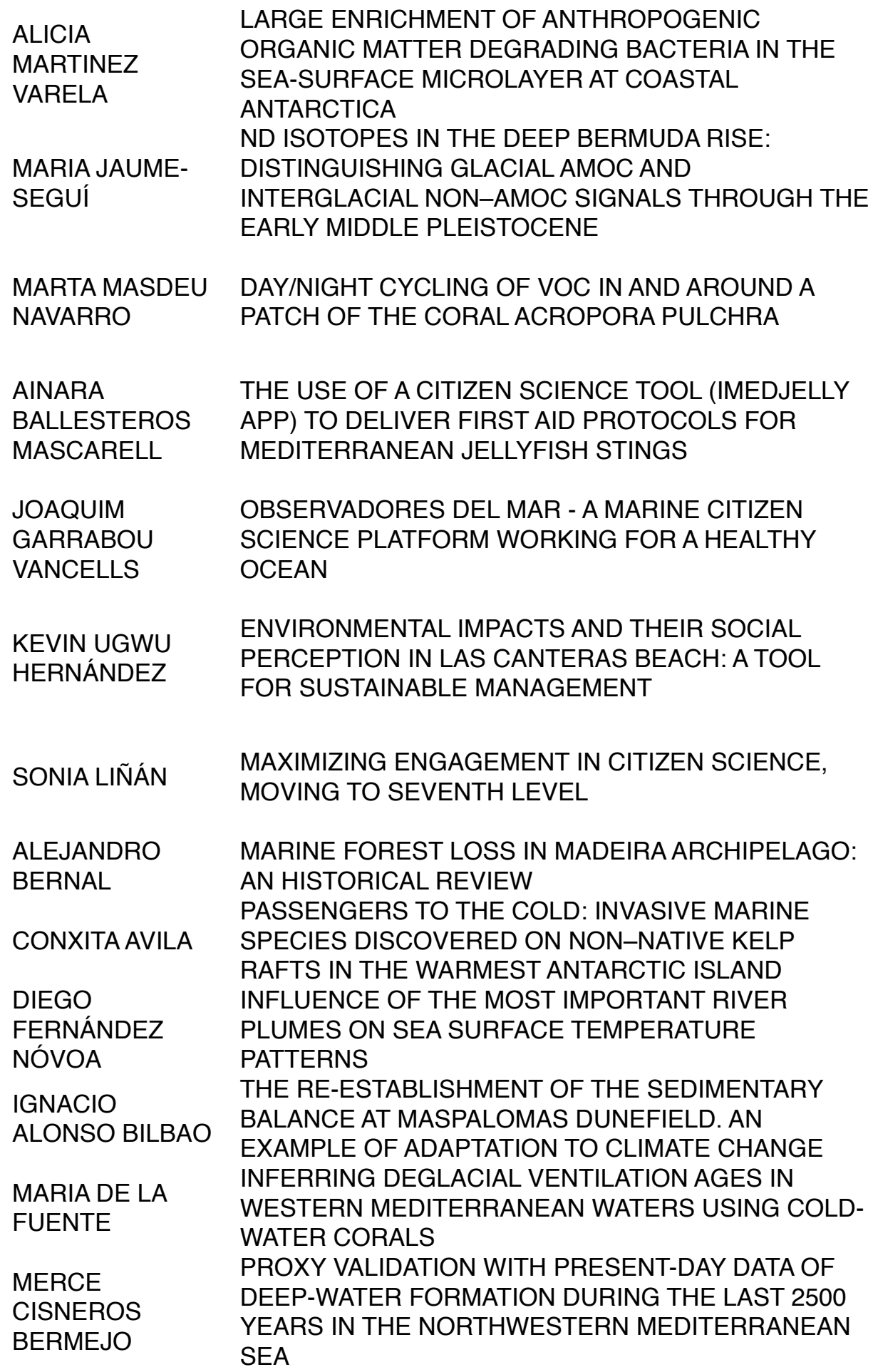

Chemical

oceanography

and

biogeochemistry

Chemical

oceanography

and

biogeochemistry

Chemical

oceanography

and

biogeochemistry

Citizen Science

and the sea:

challenges and

opportunities

Citizen Science

and the sea:

challenges and

opportunities

Citizen Science

and the sea:

challenges and

opportunities

Citizen Science

and the sea:

challenges and

opportunities

Climate Change

and the ocean

Climate Change and the ocean

Climate Change and the ocean

Climate Change and the ocean

Climate Change and the ocean

Climate Change and the ocean 


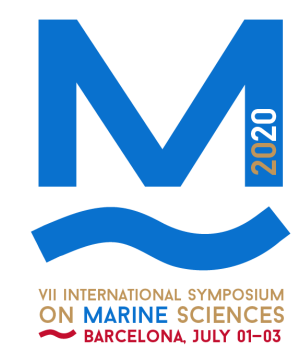

MIGUEL ÁNGEL GUTIÉRREZ

GUERRA

NATALIA PETITMARTY

RUTH ROMERO

MARTÍN

SANDRA

RAQUEL DE

MELO VIEIRA

MARTINS

REBOCHO

THET OO MON

ANTONIO M. CALAFAT FRAU

MARIA

FERNÁNDEZ

MACIÀ

MARÍA LÓPEZ

BELZUNCE

MASUMA

CHOWDHURY

ANA TUBÍO

GÓMEZ

ANDREA

CASAUCAO

AGUILAR

ANYELL

CADERNO PEÑA

CARLOS

RODRÍGUEZ

GARCÍA

CLAUDIA

CAMPANINI

ELENA LLORET

LLORET

ESTELA

CARBONELL

GARZÓN
LONG TERM TREND IN SURFACE TEMPERATURE IN THE CANARY ISLANDS FROM IN-SITU

OBSERVATIONS

NATURAL CO2 SEEPS GIVE CLUES ABOUT FISH

ADAPTATION TO OCEAN ACIDIFICATION

IDENTIFYING HOMOGENOUS COASTAL UNITS IN

TERMS OF VULNERABILITY AND ADAPTATION

CAPACITY TO CLIMATE CHANGE

OCEAN WARMING AND ACIDIFICATION IMPACTS ON

ENERGY BUDGET AND OXIDATIVE RESPONSES OF

ZEBRA SEABREAM (DIPLODUS CERVINUS)

COASTAL HAZARD EVOLUTION UNDER DIFFERENT

CLIMATE CHANGE SCENARIOS IN RIA FORMOSA, PORTUGAL

HISTORICAL BEACH EVOLUTION AND CURRENT STATUS OF THE MARESME LITTORAL CELL

RECOVERY OF THE COAST OF HUELVA AFTER THE STORM EMMA

ENVIRONMENTAL EVIDENCES OF "ALBUFERA DE VALENCIA" COASTAL BARRIER STABILISATION FROM 8,500 YR BP TO PRESENT

PATTERNS OF VARIABILITY OF SATELLITE DERIVED OPTICAL PARAMETERS IN THE MEGHNA ESTUARY

AND THEIR RESPONSE TO CLIMATIC INDICES SUSTAINABLE MANAGEMENT OF ARTISANAL

SWORD RAZOR CLAM FISHERIES IN GALICIA (NW

SPAIN): THE IMPORTANCE OF MATCHING

MANAGEMENT WITH THE REPRODUCTIVE CYCLE

LAGRANGIAN DISPERSION AND SPATIAL

DISTRIBUTION OF EARLY STAGES OF ANCHOVY

(ENGRAULIS ENCRASICOLUS) IN THE GULF OF

CÁDIZ IN 2016

CAN SHELLFISH AFFECT THE GROWTH OF SOLEN

MARGINATUS (PULTENEY, 1799)?

ANALYSIS AND CHARACTERIZATION OF DISCARDS

IN THE GULF OF CÁDIZ (SW SPAIN). RESULTS OF

THE ECOFISH PROJECT.

BIOENERGETIC OF SMALL PELAGIC FISHES:

FATMETER ANALYSIS AS SURROGATE OF

CALORIMETRY TO ESTIMATE ENERGY CONTENT OF

EUROPEAN SARDINE AND EUROPEAN ANCHOVY

SEASONAL SPATIAL PATTERNS OF A HIGHLY

COMMERCIAL SPECIES RELATE TO PREY

DISTRIBUTION AND TROPHIC BEHAVIOUR

VARIABILITY OF DIFFERENT SAMPLING METHODS

APPLIED TO MARINE AQUACULTURE IMPACT

MONITORING
Climate Change

and the ocean

28

Climate Change and the ocean

29

Climate Change and the ocean

Climate Change and the ocean

Climate Change and the ocean

Coastal and estuarine systems Coastal and estuarine systems Coastal and estuarine systems Coastal and estuarine systems

Living resources 46

Living resources

Living resources

Living resources

Living resources

Living resources

Living resources 


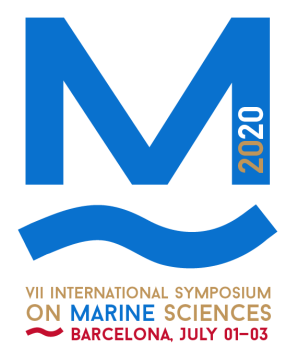

ESTHER ARCAS SEN

IK RODRÍGUEZ

VITE

IRAIS MAGALLI

SÁNCHEZ

TORRES

IRAIS MAGALLI

SÁNCHEZ

TORRES

JOAN O.

GRIMALT

MARINA

BIBILONI

SOCIAS

MARTA

CARRETON

MIGUEL TORRES

RODRÍGUEZ

RODRIGO

LÓPEZ SALAZAR

XÈNIA FRIGOLA

TEPE

OIHANA SOLAUN

PERRINE

NANTOIS

ALEX PARERA

GARCIA

ANDREA GORI

CARLOS VELOY

DOMÍNGUEZ
STUDY OF THE COMMON OCTOPUS FISHERY IN THE VALENCIAN COMMUNITY. PROPOSALS TO IMPROVE ITS MANAGEMENT HARVEST RATE FOR THE ECOSYSTEM-BASED LIMIT REFERENCE POINT FOR THE THREAD HERRING FISHERY OF THE SOUTHERN GULF OF CALIFORNIA

APPROACH TO THE DIGESTIVE ONTOGENIA FOR THE CULTURE OF PACIFIC PYGMY OCTOPUS

Living resources

59

Living resources

60

Living resources

61

EFFECT OF THE INTAKE OF ADDITIONAL SOLUBLE

PROTEIN ON THE GROWTH, SURVIVAL AND

METABOLIC RESERVES IN JUVENILES OF THE RED

Living resources

62

OCTOPUS, OCTOPUS MAYA

MERCURY ACCUMULATION IN MEDITERRANEAN

LEAN FISH

Living resources

63

A NEW SUSCEPTYBILITY TO FISHING INDEX:

PRELIMINARY RESULTS TO EVALUATE THE STATE

OF EXPLOITATION OF TARGET AND BY-CATCH

SPECIES OF THE BALEARIC ISLANDS BOTTOM-

TRAWL FISHERY

ABUNDANCE AND DISTRIBUTION OF THE DEEP-SEA

BLUE AND RED SHRIMP ARISTEUS ANTENNATUS

LARVAE ALONG THE SPANISH MEDITERRANEAN

COAST

VERY LONG-CHAIN (>C24) POLYUNSATURATED

FATTY ACIDS IN MARINE FISH: NUTRITIONAL

REGULATION OF GENES INVOLVED IN THEIR

BIOSYNTHESIS IN SPARUS AURATA AND SOLEA

SENEGALENSIS

ESTIMATION OF THE POTENTIAL SPATIAL

DISTRIBUTION OF SPECIES CAUGHT BY THE

ARTISANAL FLEET OFF THE YUCATAN PENINSULA

PRELIMINARY RESULTS ON THE EUROPEAN

SARDINE CONDITION

OCCURRENCE OF EU WATCH LIST SUBSTANCES IN

WASTEWATER AND RECEIVING WATER WITHIN THE

BASQUE ESTUARIES AND COAST

BALLAST WATER DISCHARGE PROFILE OF LAS

PALMAS PORT AS AN INPUT FOR RISK ASSESSMENT

AND MANAGEMENT IN THE ATLANTIC AREA:

PRELIMINARY RESULTS

BIODIVERSITY IN ANTHROPIZED MARINAS. THE

CASE OF THE BATH AREA OF THE FORUM OF

BARCELONA (SPAIN)

PERFORMACE OF THE COLD-WATER CORAL LOPHELIA PERTUSA UNDER NATURAL THERMAL VARIABILITY

SPATIO-TEMPORAL CHANGE OF INDICATORS OF MARINE COMMUNITIES ALONG A LATITUDINAL

GRADIENT IN THE WESTERN MEDITERRANEAN SEA
Living resources

65

Living resources

64

Living resources

66

Living resources

68

Living resources

69

Management of

the marine

environment

Management of

the marine

environment

Marine

biodiversity

Marine

biodiversity

79

Marine

biodiversity 


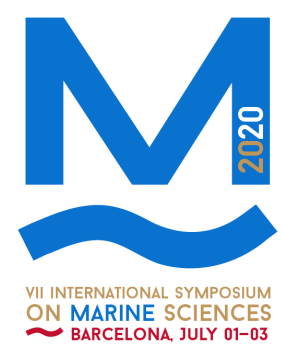

DESIREE
PALOMINO
CANTERO
FREE ESPINOSA
(PATRICIA FORT
- INSCRITA)
JÚLIA MULET
ORTEGA
MANUEL
BALLESTEROS
MARCO
FRANCESCANG
ELI
SEBATIA
HERNANDIS
CABALLERO
ALBA FUSTER
ALONSO
ALICIA GRAN
GARCÍA
ANDREU
BLANCO
CARTAGENA
FABIO BLANCO
MURILLO

TRAWLING FOOTPRINT AND DIVERSITY OF BENTHIC COMMUNITIES IN THE MENORCA CHANNEL (WESTERN MEDITERRANEAN)

Marine

biodiversity

83

LIFE REMOPAF PROJECT (RECOVERY OF

ENDANGERED MOLLUSC PATELLA FERRUGINEA)

Marine

biodiversity

85

REPEATABILITY OF BEHAVIOUR IN THE PEARLY

RAZORFISH (XYRICHTYS NOVACULA): SEX AND

BODY SIZE EFFECTS

VEGAN NUDIBRANCHS? FEEDING BEHAVIOR OF

THE CRYPTIC NUDIBRANCH POLYCERELLA

EMERTONI ASSOCIATED WITH THE PSEUDO-

INDIGENOUS BRYOZOAN AMATHIA VERTICILLATA

IMPLEMENTATION OF THE OBSEA COASTAL

SEAFLOOR OBSERVATORY TO DERIVE ECOLOGICAL

INDICATORS

AGE AND GROWTH INDICATE THAT THE REMAINING

PINNA NOBILIS POPULATIONS LIVING IN SPAIN ARE

HIGHLY THREATENED AND VULNERABLE

ANALYSIS OF THE SEDIMENT ASSOCIATED WITH

POSIDONIA OCEANICA'S WRACK ON THE COAST OF

ALICANTE (WESTERN MEDITERRANEAN).

MAPPING AND MONITORING OF A TREPTACANTHA

BARBATA RESTORED POPULATION IN MENORCA

MAPPING INVASIVE MACROALGAE IN NW IBERIAN

PENINSULA

Marine

biodiversity

87

Marine

biodiversity

Marine

biodiversity

Marine

biodiversity

93

Marine

ecosystems

96

Marine

ecosystems

98

Marine

ecosystems

100

20 YEARS OF POSIDONIA OCEANICA MONITORING

ALONG THE ALICANTE COAST (5W

MEDITERRANEAN) THE EFFECT ON VOLUNTEERING

MARINE PRODUCTION SPIKES OWING TO HEAVY

FRANCESC

PETERS

STORM GLORIA IN A NW WESTERN

MEDITERRANEAN COASTAL SITE WITH A

DECREASING CHLOROPHYLL TREND.

INMACULADA

MONTERO

GONZALEZ

STUDY OF THE REPRODUCTIVE ECOLOGY OF

SPICARA SMARIS IN THE IBIZA ISLAND.

Marine

ecosystems

102

Marine

ecosystems

104

Marine

ecosystems

105

CHANGES IN THE POPULATION STRUCTURE OF

ISABEL ESTESO

CALLINECTES SAPIDUS RATHBUN 1896 IN

PERONA

DIFFERENT INTERCONNECTED COASTAL HABITATS

OF SE PENINSULA IBERICA (MEDITERRÁNEO

Marine

ecosystems

106

OCCIDENTAL)

JOAQUIM

TOMÀS FERRER

POTENTIAL VULNERABILITY OF DEMERSAL

FISHERIES TO WESTERN MEDITERRANEAN

WARMING

JOAQUIM

RECRUITMENT VARIABILITY OF THE STRIPED RED

TOMÀS FERRER

MULLET (MULLUS SURMULETUS) STOCK IN THE

BALEARIC SEA (WESTERN MEDITERRANEAN)

EVIDENCES OF SEXUAL SEGREGATION IN A

LOLA RIESGO

COMMON DEEP-SEA SHARK: IMPLICATIONS FOR

CONSERVATION AND MANAGEMENT

Marine

ecosystems

107

Marine

ecosystems

108

Marine

ecosystems 


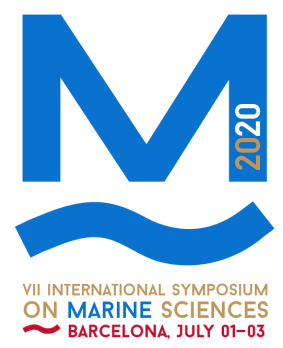

\begin{tabular}{ll} 
MARTA COLL & ADVANCING FOOD-WEB MODELLING CAPABILITIES \\
& TO ANALYSE GLOBAL OCEAN FUTURES \\
MIQUEL CANALS & ECOSYSTEM RECOVERY 30 MONTHS AFTER THE \\
& HIERRO \\
RAIBEL & ISOTOPIC DISTRIBUTION OF BLUE SHARK \\
ZELIDETH & (PRIONACE GLAUCA) IN THE WEST COAST OF BAJA \\
NUNEEZ- & CALIFORNIA SUR, MEXICO \\
GONZALEZ & SPATIO-TEMPORAL VARIABILITY OF AMPHIPOD \\
SANDRA & ASSEMBLAGES ASSOCIATED WITH RHODOLITH \\
NAVARRO & SEABEDS \\
MAYORAL & UNRAVELLING THE CHEMICAL SIGNATURE OF \\
ALBERT CATALÀ & ALBORAN SEA SEDIMENTS TO DETECT HOLOCENE \\
I CAPARRÓS & HUMIDITY CHANGES IN SOUTHERN IBERIA \\
& MARINE SUBSOIL INVESTIGATIONS FOR OFFSHORE \\
AMADEU DEU & WIND FARMS AND SUBMARINE INTERCONNECTION \\
LOZANO & CABLES \\
AMADEU DEU & THERMAL PROPERTIES OF MARINE SEDIMENTS \\
LOZANO & TEMPERATURE AND CONDUCTIVITY ANOMALIES AS \\
ANNA OLIVÉ & A PROXY FOR VOLCANIC ACTIVITY AT THE TAGORO \\
ABELLÓ & SUBMARINE VOLCANO IN THE CANARY ISLANDS \\
& CREATING A SD SEISMIC CUBE FROM 2D HIGH- \\
EMMA & RESOLUTION SEISMIC PROFILES. A CASE STUDY \\
SOLDEVILA & FROM THE MARINE MINE TAILINGS DEPOSIT IN \\
MOLDES & PORTMÁN BAY, SPAIN \\
& THE FAST TRANSFORMATION OF THE \\
MIQUEL CANALS S & MEDITERRANEAN DEEP SEAFLOOR \\
NIL RODES I & GEOMETRY, STRUCTURE AND STABILITY OF THE \\
LLORENS & SUBMARINE EXTENSION OF THE MINE TAILINGS \\
& DEPOSIT OF PORTMÁN BAY, SPAIN \\
\hline
\end{tabular}

ANA BARTUAL IMAGING FLOW CYTOMETRY AS A TOOL FOR THE MAGRO STUDY OF CYANOBACTERIAL AGGREGATION

\section{CARLES GALIÀ \\ PREDICTING 2B-RAD LOCI ABUNDANCE AND TESTING RESULTS IN STYELA PLICATA}

DANIEL RICKUE BONDYALE JUEZ
RESPIRATION, PROTEIN, LIPID \& CARBOHYDRATE COMPOSITION IN PHYSALIA PHYSALIS AND VELELLA VELELLA. PREDATOR AND PREY OF THE PLEUSTON.
Marine

ecosystems 111

Marine

ecosystems

Marine

ecosystems

115

Marine

ecosystems

Marine

geosciences

Marine

geosciences

121

Marine

geosciences

122

Marine

geosciences

123

Marine

geosciences

125

Marine

Geosciences

126

Marine

geosciences

127

Microbiology,

genetics,

biotechnology

and molecular

biology

Microbiology,

genetics,

biotechnology

and molecular

biology

Microbiology, genetics,

biotechnology

and molecular

biology 
DANIELA MARIA PORFÍRIO RODRIGUES

EIRINI SCHOINA

\author{
GIORGIA \\ PALLADINO \\ JOÃO MIGUEL \\ MENDES \\ FERREIRA
}

LUCIA PITA

ANNA OLIVÉ
ABELLÓ
CAROLINA
GABARRO
PRATS
DAVID AMBLAS

MARÍA DE LA

LUZ GUTIÉRREZ

MARTÍNEZ

TANIA MONTOTO MARTÍNEZ

\author{
ADRIÁN \\ FERNÁNDEZ \\ BALADRÓN \\ ISABEL \\ CABALLERO DE \\ FRUTOS
}

COMPARATIVE LIPID PROFILE OF HERMETIA ILLUCENS FED WITH TWO DIFFERENT SEAWEEDS TO ENHANCE THEIR FATTY ACID PROFILE

EVALUATION OF ISOEUGENOL IN STUNNING/KILLING GILTHEAD SEA BREAM (SPARUS AURATA L.)

SEA ANEMONE (ANEMONIA VIRIDIS) MICROBIOME CHARACTERIZATION ACROSS SEASONALITY IN THE NORTH ADRIATIC SEA

RED SEAWEEDS GRATELOUPIA TURUTURU AND PORPHYRA UMBILICALIS AS A MARINE RESOURCE A STUDY ON THE PHENOLIC COMPOSITION AND BIOACTIVE PROPERTIES

DECODING SPONGE RESPONSES TO A DYNAMIC ENVIRONMENT BY RNA-SEQ

PROPERTY BALANCES IN THE SCOTIA SEA AS DEDUCED FROM INVERSE MODELLING ASSESSMENT OF THE CORRELATION BETWEEN RIVER DISCHARGE AND SEA ICE GROWING IN LAPTEV SEA MODELING THE DOWNSLOPE PROPAGATION OF DENSE SHELF WATER FLOWS IN ANTARCTICA

ICHTHYOFAUNA OF THE BAJA CALIFORNIA PENINSULA DEPICTED ON THE ROCK PAINTINGS OF SIERRA DE SAN FRANCISCO AND SIERRA DE GUADALUPE, MEXICO

\section{MOTIVATIONS AND CONCERNS OF EARLY CAREER MARINE RESEARCHERS}

DOWNSCALING OF WRF1,3 MODEL OUTPUT IN THE RIA DE VIGO

SENTINEL-2A/B SATELLITES FOR AQUATIC AND COASTAL SCIENCE APPLICATIONS
Microbiology, genetics, biotechnology and molecular biology Microbiology, genetics, biotechnology and molecular biology Microbiology, genetics, biotechnology and molecular biology Microbiology, genetics, biotechnology and molecular biology Microbiology, genetics, biotechnology and molecular biology Polar marine research

Polar marine research

Polar marine research Social sciences, museums and outreach in Marine

Sciences Social sciences, museums and outreach in Marine Sciences Technologies and data management Technologies and data management 


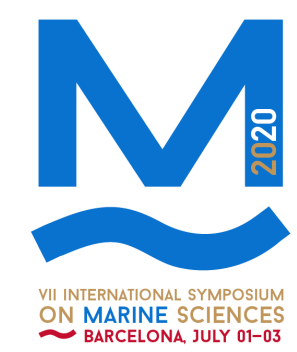

\begin{tabular}{|c|c|}
\hline JAUME PIERA & $\begin{array}{l}\text { A MINIMUM VIABLE ECOSYSTEM OF SERVICES FOR } \\
\text { CITIZEN OBSERVATORIES: COS4CLOUD TACKLING } \\
\text { TECHNOLOGICAL CHALLENGES IN THE AGE OF } \\
\text { OPEN SCIENCE }\end{array}$ \\
\hline $\begin{array}{l}\text { ÚLIA URPI } \\
\text { BADELL }\end{array}$ & $\begin{array}{l}\text { HIGH-RESOLUTION BATHYMETRIC MONITORING } \\
\text { USING 3D POINT CLOUD DATA ANALYSIS }\end{array}$ \\
\hline $\begin{array}{l}\text { ILIAN TOLEDO } \\
\text { UEDES }\end{array}$ & $\begin{array}{l}\text { MACCAM: A PROXY TO CARRYING CAPACITY FOR } \\
\text { MEDITERRANEAN AQUACULTURE }\end{array}$ \\
\hline $\begin{array}{l}\text { MARCO } \\
\text { SIGNAROLI }\end{array}$ & $\begin{array}{l}\text { REAL-TIME MARINE FISH DETECTION USING DEEP } \\
\text { LEARNING FOR BEHAVIOURAL STUDIES UNDER } \\
\text { LABORATORY CONDITIONS }\end{array}$ \\
\hline $\begin{array}{l}\text { ANGEL } \\
\text { RODRÍGUEZ } \\
\text { SANTANA }\end{array}$ & $\begin{array}{l}\text { THERMOHALINE INTRUSIONS AND DIAPYCNAL } \\
\text { MIXING IN THE CAPE VERDE FRONTAL ZONE }\end{array}$ \\
\hline $\begin{array}{l}\text { BORJA AGUIAR } \\
\text { GONZÁLEZ }\end{array}$ & $\begin{array}{l}\text { EDDY CORRIDORS OF THE NORTHEASTERN } \\
\text { TROPICAL AND SUBTROPICAL ATLANTIC OCEAN }\end{array}$ \\
\hline $\begin{array}{l}\text { EVGENIIA } \\
\text { MAKAROVA }\end{array}$ & $\begin{array}{l}\text { N OF THE ERA* OCEAN FORCING } \\
\text { NDER STORM SURGE CONDITIONS IN } \\
\text { IC SEA }\end{array}$ \\
\hline $\begin{array}{l}\text { IGNASI VALLÈS } \\
\text { CASANOVA }\end{array}$ & $\begin{array}{l}\text { TIOTEMPORAL DIVERSITY OF ATLANTIC } \\
\text { SSOCIATED RAINFALL VARIABILITY } \\
\text { AFRICA AND SOUTH AMERICA. }\end{array}$ \\
\hline $\begin{array}{l}\text { INÉS } \\
\text { HERNÁNDEZ } \\
\text { GARCÍA }\end{array}$ & $\begin{array}{l}\text { EXPLORING HYDROGRAPHICAL STRUCTURES IN } \\
\text { THE CAPE VERDE FRONTAL ZONE THROUGH IN } \\
\text { SITU DATA AND NUMERICAL MODELLING DURING } \\
\text { FLUXES-II SURVEY } \\
\text { TESTING THE ROLE OF MEDITERRANEAN }\end{array}$ \\
\hline ISABEL CACHO & $\begin{array}{l}\text { THERMOHALINE CIRCULATION AS A SENSOR OF } \\
\text { TRANSIENT CLIMATE EVENTS (TIMED-PROJECT) } \\
\text { WHERE DO THE NEAR-BOUNDARY SUBPOLAR }\end{array}$ \\
\hline $\begin{array}{l}\text { JUAN MANUEL } \\
\text { SAYOL }\end{array}$ & $\begin{array}{l}\text { NORTH ATLANTIC SINKING WATERS GO? A } \\
\text { LAGRANGIAN-BASED STUDY WITH A HIGH- } \\
\text { RESOLUTION GLOBAL OCEAN MODEL }\end{array}$ \\
\hline AARINA & $\begin{array}{l}\text { DYNAMIC OF THE NORTH-WESTERN ALBORAN SEA } \\
\text { UPWELLING FROM LOCAL AND REMOTE }\end{array}$ \\
\hline ENAGOS & \\
\hline
\end{tabular}

Technologies

and data

management

Technologies

and data

management

Technologies

and data

management

Technologies

and data

management

The physical

bases of Marine

Sciences

The physical

bases of Marine

Sciences

The physical

bases of Marine

Sciences

The physical

bases of Marine

Sciences

The physical

bases of Marine

Sciences

The physical

bases of Marine

Sciences

The physical

bases of Marine

Sciences

The physical bases of Marine

Sciences
161

163

164

165

167

169

170

172

174

176

178

180 


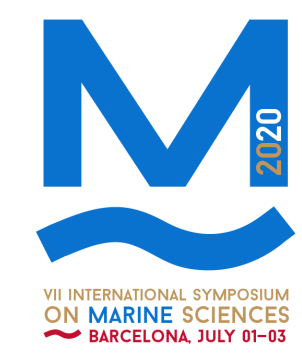

\section{POSTER COMMUNICATIONS}

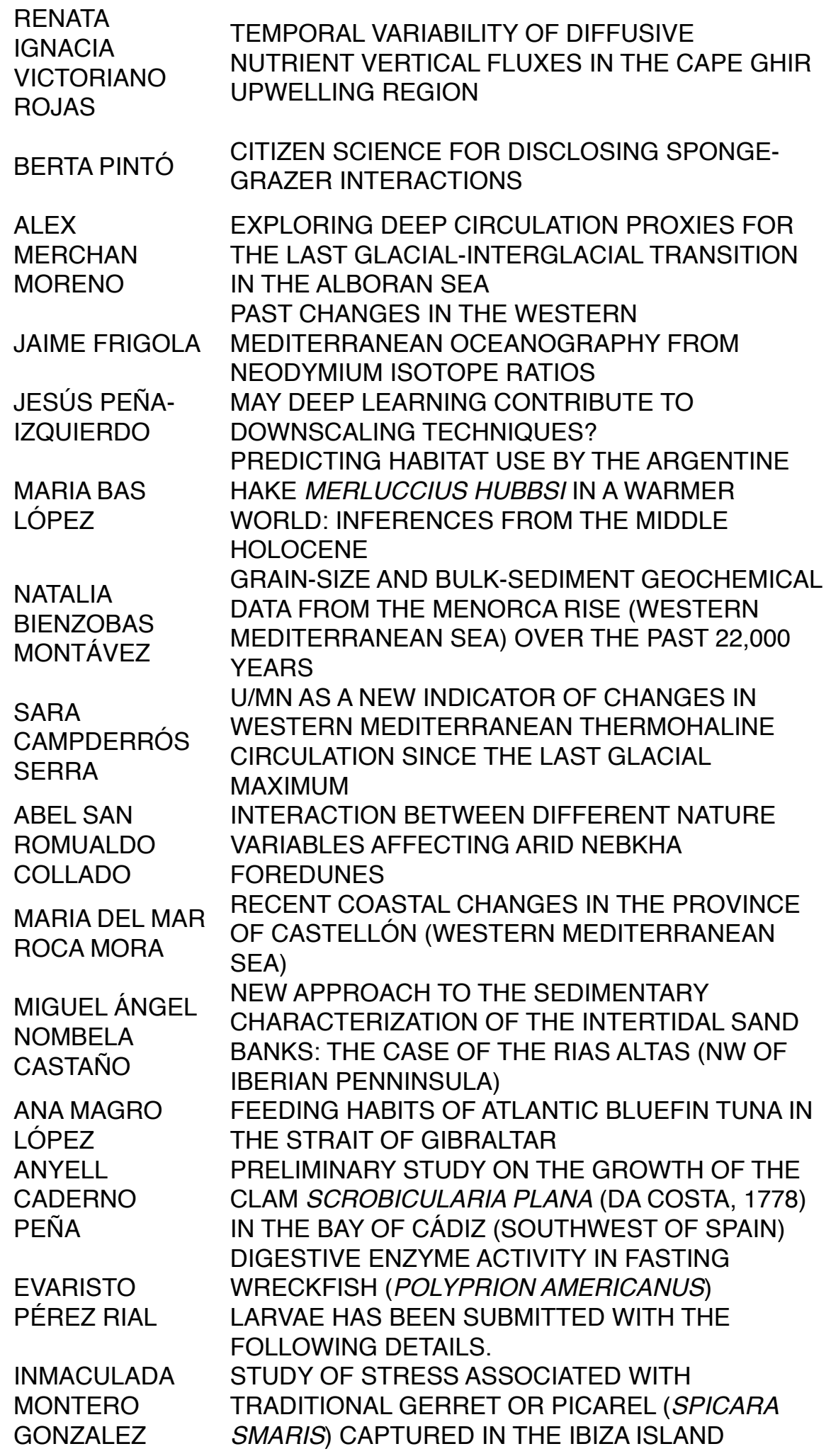

Chemical

oceanography and

biogeochemistry

Citizen Science and the sea - challenges and opportunities

Climate change and the ocean

184

186

Climate change and the ocean

Climate change and the ocean

Climate change and the ocean

Climate change and the ocean

Climate change and the ocean

Coastal and estuarine systems

Coastal and estuarine systems

Coastal and estuarine systems 


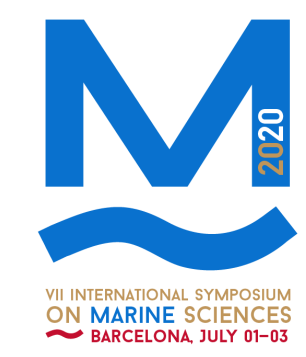

MARIA
CONSTENLA
MIREIA CANET
CHAQUÉS

ASSESSMENT OF THE HEALTH STATUS OF

MARINE ORGANISMS WITH RELEVANCE FOR

FISHERIES IN CATALONIA

Living resources

212

THE DEPLOYMENT OF SKIRTS TO KEEP SEA LICE

CHAQUÉS

OUT OF SALMON PENS AFFECTS TO

ZOOPLANKTON COMMUNITY STRUCTURE IN THE

Living resources

214

NORWEGIAN FJORDS

COULD MUSSEL AQUACULTURE AFFECTS THE

MIREIA CANET

ABUNDANCE OF LEPADOGASTER CANDOLII

CHAQUÉS

(RISSO, 1810) DUE TO THE SEDIMENTATION OF

ORGANIC MATTER?

ÓSCAR DIET COMPOSITIONS OF COMMERCIAL FISH

MORENO

SPECIES INHABITING SHALLOWER WATERS OFF

ESCALANTE

TANIA

THE COAST OF HUELVA (SW SPAIN)

SPAWNING AND LARVAL DEVELOPMENT OF

BALLESTEROS

OTERO

HOLOTHURIA FORSKALI, A NEW CANDIDATE FOR

AQUACULTURE

JUAN PANTOJA

PÉREZ

IMPACT OF TOURISM OVER TRADITIONAL

FISHERIES IN IBIZA ISLAND

EVOLUTION OF THE CATCH PER UNIT OF

JUAN PANTOJA

EFFORT (CPUE) OF THE SMALL-SCALE

PÉREZ

FISHERIES OF SPICARA SMARIS IN THE ISLAND

OF IBIZA

ALBERTO

CHARACTERIZATION OF TWELVE SPECIES OF

GARCÍA

GONZÁLEZ

THE MACRO-INFAUNA OF THE CADIZ COAST

BEACHES (SOUTHWEST OF SPAIN)

TRAVELING WITH LIVING CORALS: THE PACIFIC

ANDREA

CABRITO

RUBAU

NUDIBRANCH BAEOLIDIA RIEAE CARMONA,

POLA, GOSLINER \& CERVERA, 2014 ARRIVES TO

BARCELONA (SPAIN) AQUARIUMS.

TWO OCEANS: BIOGEOGRAPHIC AND

DARÍO

CÓRDOBA

GONZÁLEZ

TAXONOMIC REVIEW OF MARINE

HETEROBRANCH SEASLUGS (MOLLUSCA:

GASTROPODA) FROM PANAMA WATERS.

(PRELIMINARY STUDY).

ENRIQUE

GONZALEZ

ORTEGON

ESTIMATING THE TROPHIC POSITION OF THE

AQUATIC CONSUMER DUGASTELLA VALENTINA

USING STABLE ISOTOPES.

ON THE DISTRIBUTION OF A FREQUENT

EULALIA

PERAZA

GONZÁLEZ

ACTINIARIA OF THE CANARY ISLANDS,

TELMATACTIS CRICOIDES (CNIDARIA,

ANTHOZOA, ACTINIARIA), AND ITS ASSOCIATED

FAUNA

GLOBAL PATTERNS AND DRIVERS OF MARINE

MARTA PAGÈS

ESCOLÀ

SESSILE BIODIVERSITY: UNRAVELING THE

SOUTHERN OCEAN AS AN IMPORTANT HOTSPOT

OF BIODIVERSITY AND CLIMATIC REFUGE.

MARTA

IDENTIFYING THE ORIGIN OF NEW

PASCUAL

COLONIZATIONS IN SEA TURTLES

Living resources

Living resources

Living resources

Management of the

marine environment

Management of the

marine environment

Marine biodiversity

Marine biodiversity

Marine biodiversity

Marine biodiversity

Marine biodiversity

Marine biodiversity

Marine biodiversity 


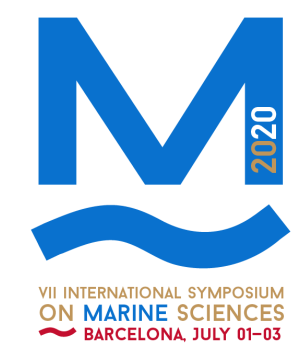

NEBIS ADRIANA POPULATION STRUCTURE OF THE STONE CRAB

NAVARRO XANTHO PORESSA (OLIVI, 1972) IN A HUMAN

Marine biodiversity

237

OJEDA

RESTRICTED ACCESS AREA

SARA MARIA

DALLARÉS

LIFE STRATEGIES AND HABITAT PREFERENCES

VILLAR

OF TWO ESPECIALIZED FISH SPECIES IN THE NW MEDITERRANEAN DEEP SEA

YOLANDA

LUCAS

RODRÍGUEZ

ALEJANDRO

CARMONA

RODRIGUEZ

AMANDA

COHEN-

SÁNCHEZ

ARIADNA

ALDRICH

RODRIGUEZ

AUNA OF THE SYLLIDAE (ANNELIDA:

POLYCHAETA) FROM SOCOTRA ARCHIPELAGO Marine biodiversity

(INDIAN OCEAN)

RAPID ASSESSMENT SURVEY OF BIOFOULING IN

TWO MARINAS OF ALICANTE (SW

MEDITERRANEAN)

DISENTANGLING FOOD WEBS IN CYMODOCEA

NODOSA: COMPARING MAIN PREYS FOR

XYRICHTYS NOVACULA USING STABLE ISOTOPE

DATA

ESTIMATION OF THE ECOLOGICAL NICHE OF THE MURICEA GENUS (OCTOCORAL) IN THE GULF OF CALIFORNIA, B.C.S (MEXICO)

STABLE OXYGEN ISOTOPES REVEAL THE

DRAGO
MASSIMILIANO

HABITAT USE OF MARINE MAMMALS IN THE AREA

MASSIMILIANO OF INFLUENCE OF THE RÍO DE LA PLATA

ESTUARY

SEASONAL PATTERNS OF BODY CONDITION AND

ELENA LLORET

LLORET

STABLE ISOTOPES OF TWO SMALL PELAGIC

FISH ALONG A LATITUDINAL GRADIENT OF THE

NORTHWESTERN MEDITERRANEAN SEA

VARIATIONS IN WATER MASSES OF THE

HELENA CHECA

SÁNCHEZ

EASTERN MEDITERRANEAN SEA DURING THE

LAST SAPROPEL (S1) INFERRED FROM

NEODYMIUM ISOTOPIC COMPOSITION IN

FORAMINIFERA

JUDIT JIMÉNEZ

VULNERABILITY OF POSIDONIA OCEANICA DEEP

CASERO

MEADOW LIMITS TO REMOTE WASTE

DISCHARGES

FEEDING ECOLOGY OF BLACKMOUTH

LOLA RIESGO

CATSHARK GALEUS MELASTOMUS RAFINESQUE,

Marine ecosystems

243

Marine ecosystems

Marine ecosystems

Marine ecosystems

Marine ecosystems

1810 IN THE PORCUPINE BANK (NE ATLANTIC)

PAULA DE

THE VARIED DIET OF THE SEA SLUG DORIS

CASTRO-

FERNÁNDEZ

SANDRA

NAVARRO

MAYORAL

SEBASTIA

HERNANDIS

CABALLERO

KERGUELENENSIS IN DECEPTION ISLAND

(SOUTH SHETLAND IS., ANTARCTICA)

TEMPORAL DYNAMICS OF AMPHIPOD

POPULATIONS ASSOCIATED WITH BIOFOULING

IN COASTAL AQUACULTURE FACILITIES

PINNA RUDIS LINNAEUS, 1758: THE FASTEST

GROWTH REPORTED FOR A BIVALVE

Marine ecosystems

261

INFLUENCE OF THE WATER'S

UXUE MUÑOZ

PHYSICOCHEMICAL CHARACTERISTICS ON THE

FORAMINIFERA BIOCENOSIS IN THE SPANISH

Marine ecosystems 


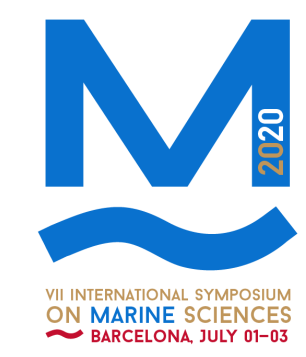

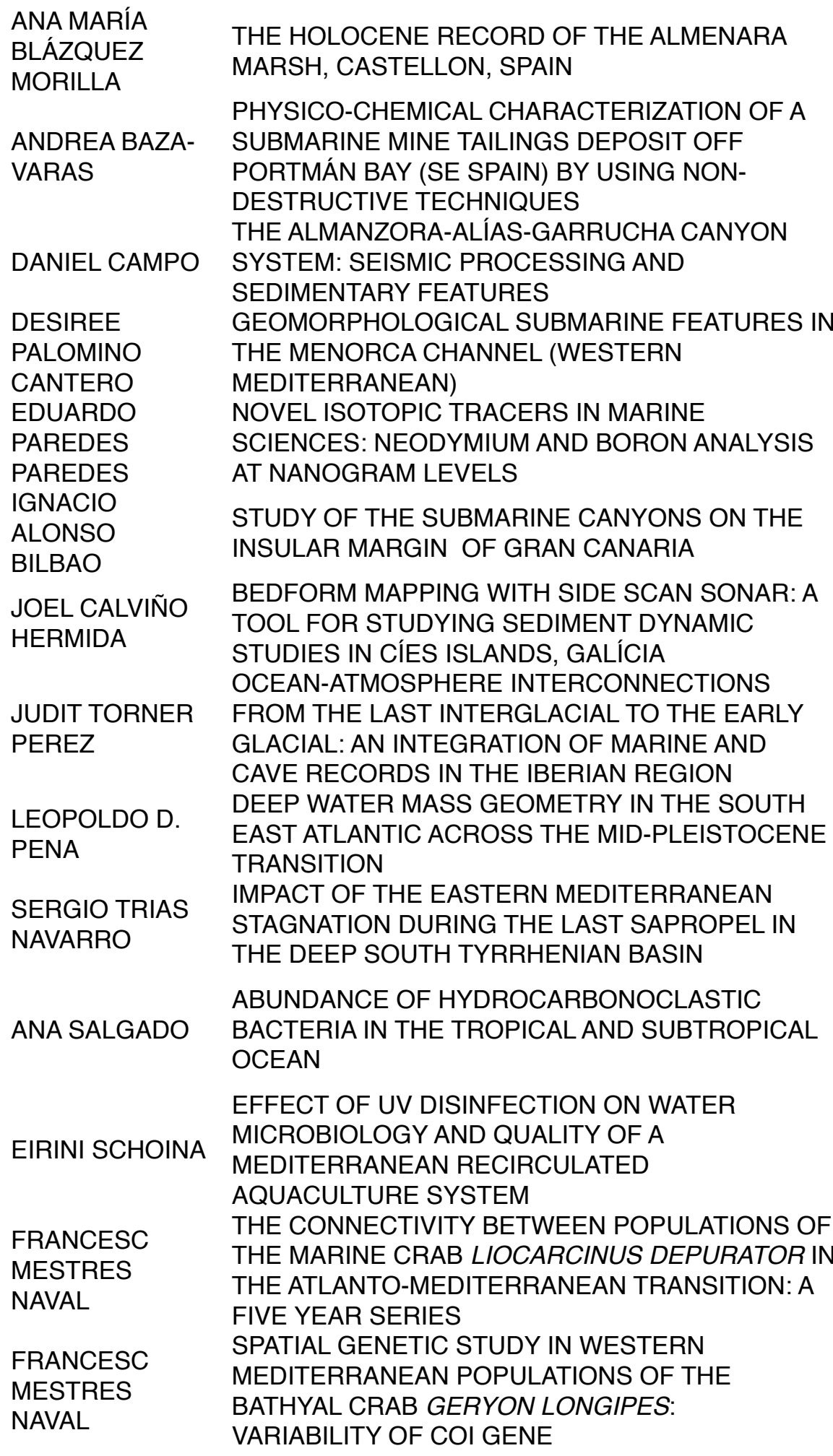

Marine geosciences

266

Marine

Geosciences

Marine

Geosciences

269

Marine geosciences

270

Marine geosciences

271

Marine geosciences

273

Marine geosciences

274

Marine geosciences

Marine geosciences

Marine geosciences

Microbiology, genetics, biotechnology and molecular biology Microbiology, genetics, biotechnology and molecular biology Microbiology, genetics, biotechnology and molecular biology Microbiology, genetics, biotechnology and molecular biology 
ICO MARTÍNEZ SÁNCHEZ

MARGHERITA
MARTA
PASCUAL

MIGUEL
TORRES
RODRÍGUEZ
MIQUEL
CANALS
CAROLINA
GABARRO
PRATS

CONXITA AVILA

CONXITA AVILA

DAVID AMBLAS

IGNACIO

ALONSO

BILBAO

JOAN

SALVADOR

FONT MUÑOZ

JÚLIA TERRA

MIRANDA

MACHADO

CRISTINA

ARUMÍ PLANAS

JOSE LUIS

GARCIA

GARCIA
AN OVERVIEW OF THE ENERGY METABOLISM DURING AURELIA AURITA'S LIFE CYCLE (FROM EPHYRA TO MEDUSA)

MICROBIOME CHARACTERIZATION OF $M$. GALLOPROVINCIALIS ALONG A SPATIAL AND TEMPORAL ENVIRONMENTAL STRESS GRADIENT

POPULATION GENOMICS AND HIERARCHICAL ANALYSES REVEAL GENETIC STRUCTURE AND ADAPTATION IN PARACENTROTUS LIVIDUS (ECHINOIDEA) PHYSIOLOGICAL ROLES OF VERY LONG-CHAIN (>C24) FATTY ACIDS DURING EARLY DEVELOPMENT OF FISH: MOLECULAR AND FUNCTIONAL CHARACTERIZATION OF ELOVL4 GENES IN SPARUS AURATA AND SOLEA SENEGALENSIS

PREDICTIVE MAPPING OF SEAGRASS

COMMUNITIES ON THE MARESME INNER SHELF, BARCELONA

KEY ENVIRONMENTAL MONITORING FOR POLAR LATITUDES AND EUROPEAN READINESS (KEPLER)

CLIMATE CHANGE AND CHEMICAL ECOLOGY: DETERMINATION OF NATURAL PRODUCTS IN

TWO SPECIES OF BRYOZOANS, HIMANTOZOUM (HIMANTOZOUM) ANTARCTICUM (CALVET, 1909) AND CHARTELLA TENELLA (HINCKS, 1887) SIGNS OF VOLCANIC ERUPTIONS IN AN ANTARCTIC MARINE BENTHIC INVERTEBRATE EFFICIENT COMPRESSION OF MULTIBEAM ECHOSOUNDERS WATER COLUMN DATA

CORRELATION STUDY BETWEEN WAVE BUOYS AND SIMAR DATA IN THE CANARY ISLANDS

ANNUAL TO DECADAL VARIABILITY PATTERNS OF HIGH NUTRIENT LOW CHLOROPHYLL REGIONS: A REMOTE SENSING PERSPECTIVE

IMPACTS OF OFFSHORE WIND FARMS ON COASTAL TOURISM ACTIVITIES IN IRELAND

ECCO: A NEW APPROACH TO ESTIMATE THE TIME VARIABILITY OF THE MERIDIONAL

OVERTURNING CIRCULATION IN THE SOUTH ATLANTIC AT $30^{\circ} \mathrm{S}$

THE CANARY EDDY CORRIDOR: LAGRANGIAN EVOLUTION OF TWO ANTICYCLONIC EDDIES BASED ON ALTIMETRY AND MODEL DATA
Microbiology,

genetics,

biotechnology and

287

molecular biology

Microbiology,

genetics,

biotechnology and

molecular biology

Microbiology,

genetics,

biotechnology and molecular biology

Microbiology,

genetics,

biotechnology and

molecular biology

Modelling in Marine

Sciences

295

Polar Marine

Research

Polar Marine

Research

Polar Marine

Research

300

Technologies and

data management

302

Technologies and

data management

304

Technologies and

data management

305

Technologies and data management

The physical bases of Marine Sciences

The physical bases of Marine Sciences 


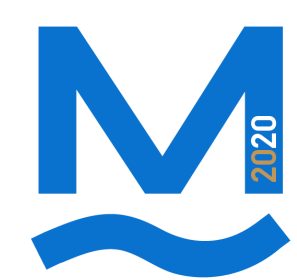

VII INTERNATIONAL SYMPOSIUM ON MARINE SCIENCES

MARTA VENY

LÓPEZ
SPATIO-TEMPORAL VARIABILITY OF THE BRANSFIELD CURRENT SYSTEM (ANTARCTICA) BASED ON DIRECT VELOCITY MEASUREMENTS
The physical bases of Marine Sciences
312 


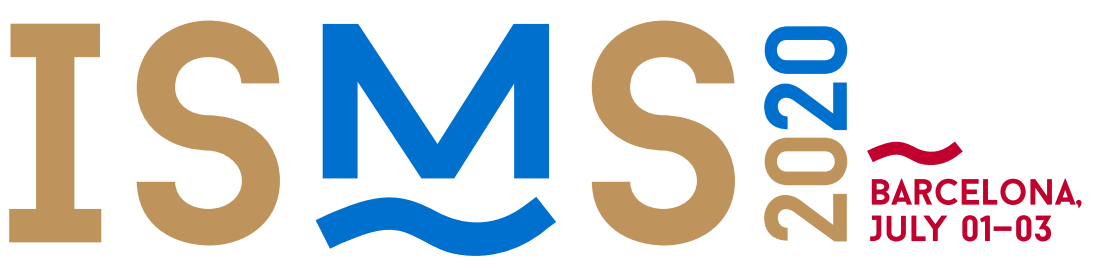

VII INTERNATIONAL SYMPOSIUM ON MARINE SCIENCES

\section{INTERNATIONAL SYMPOSIUM ON MARINE SCIENCES}

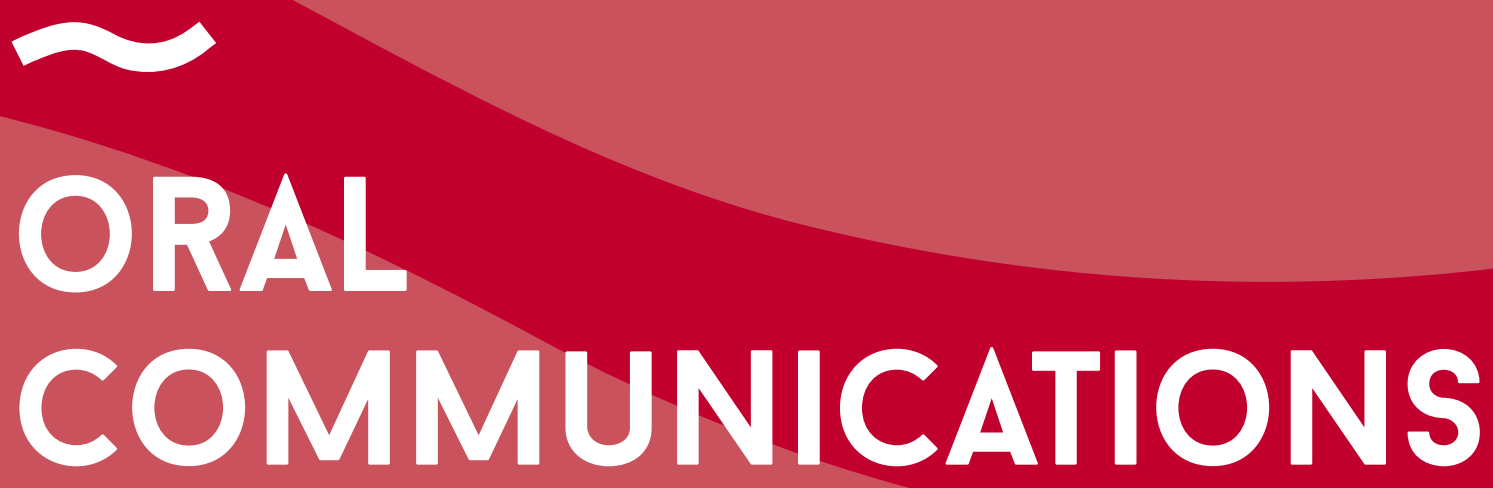




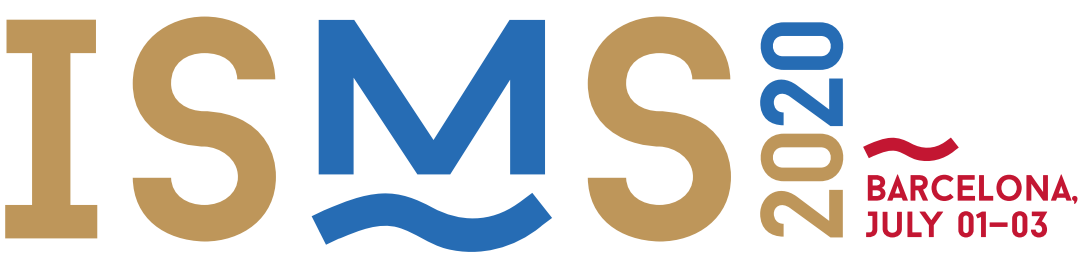

VII INTERNATIONAL SYMPOSIUM ON MARINE SCIENCES BARCELONA
JULY 01-03
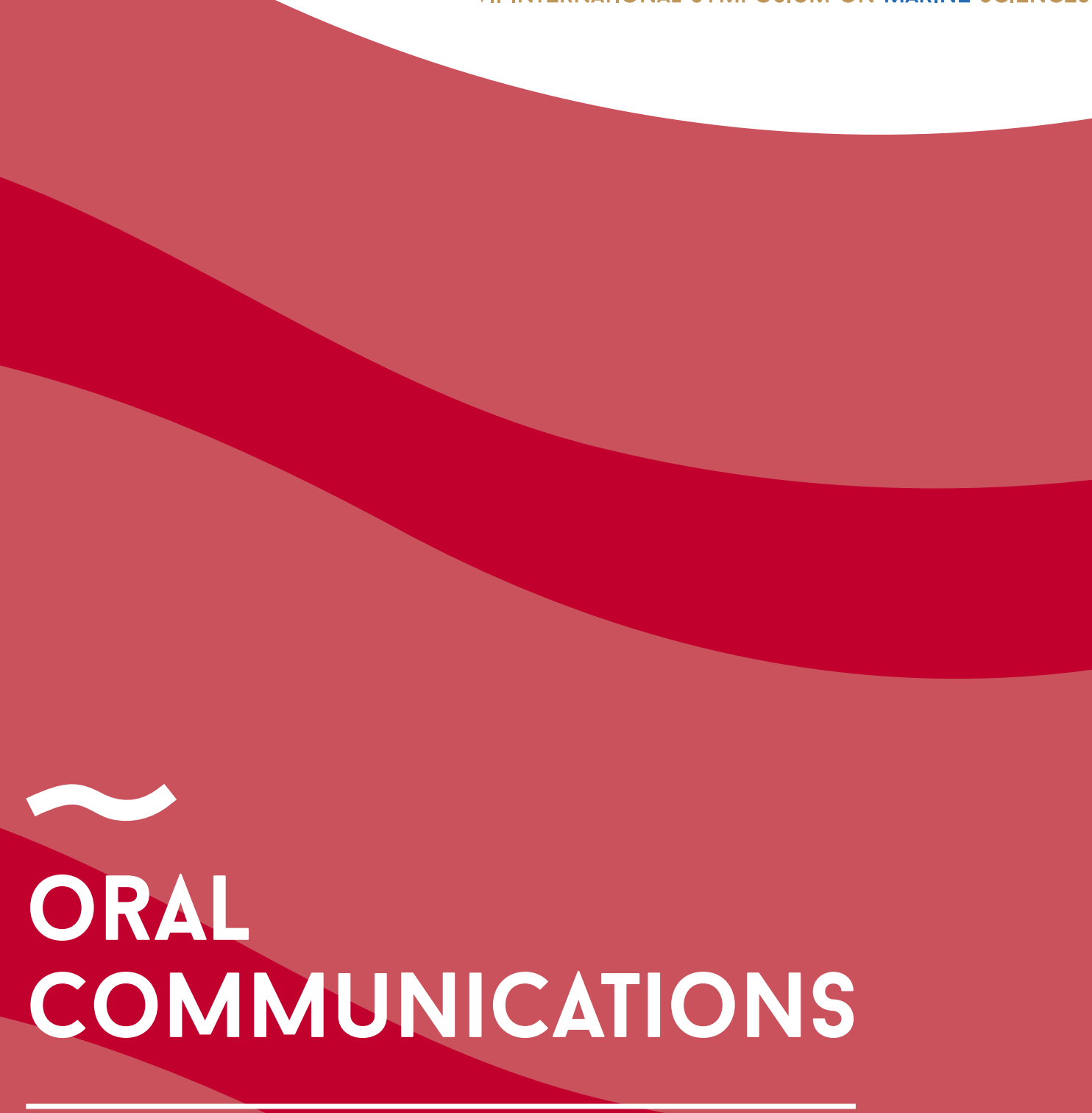

\section{CHEMICAL}

OCEANOGRAPHY AND BIOGEOCHEMISTRY 


\title{
LARGE ENRICHMENT OF ANTHROPOGENIC ORGANIC MATTER DEGRADING BACTERIA IN THE SEA-SURFACE MICROLAYER AT COASTAL ANTARCTICA
}

\author{
A. Martinez-Varela ${ }^{* 1}$, G. Casas ${ }^{* 1}$, B. Piña ${ }^{1}$, J. Dachs ${ }^{1}$ and M. Vila-Costa ${ }^{1}$. \\ ${ }^{1}$ Department of Environmental Chemistry, Institute of Environmental Assessment and \\ Water Research, IDAEA-CSIC; Barcelona, Catalunya, SPAIN. \\ amvqam@cid.csic.es,gcpqam@cid.csic.es,bpcbmc@cid.csic.es,jdmqam@cid.csic.es \\ andmvcqam@cid.csic.es
}

\begin{abstract}
The composition of bacteria inhabiting the sea-surface microlayer (SML) is poorly characterized and yet undescribed for the Southern Ocean, despite their relevance for the biogeochemistry of the surface ocean. We report the abundances and microbial diversity of bacteria inhabiting the SML and the subsurface waters (SSL) determined from a unique sample set from a polar coastal ecosystem (Livingston Island, Antarctica). From early to late austral summer (January-March 2018), we consistently found a higher abundance of bacteria in the SML than in the SSL. The SML was enriched in some Gammaproteobacteria taxa known to degrade a wide range of semivolatile, hydrophobic, and surfactant-like organic pollutants. Hydrocarbons and other synthetic chemicals including surfactants, such as perfluooroalkyl substances (PFAS), reach remote marine environments by atmospheric transport and deposition and by oceanic currents, and are known to accumulate in the SML. Relative abundances of specific SML-enriched bacterial groups were significantly correlated to concentrations of PFASs, taken as a proxy of hydrophobic anthropogenic pollutants present in the SML and its stability. Our observations provide evidence for an important pollutant-bacteria interaction in the marine SML. Given that pollutant emissions have increased during the Anthropocene, our results point to the need to assess chemical pollution as a factor modulating marine microbiomes in the contemporaneous and future oceans.
\end{abstract}

Key words: Sea-surface Microlayer, Anthropogenic Dissolved Organic Carbon, Organic Pollutants, Microbial Communities 


\title{
Nd Isotopes in the Deep Bermuda Rise: Distinguishing Glacial AMOC and Interglacial non-AMOC Signals through the Early Middle Pleistocene
}

\author{
M. Jaume-Seguí ${ }^{1,2}$, J. Kim ${ }^{2,3}$, L.D. Pena1, S.L. Goldstein ${ }^{2,3}$, K.P. Knudson ${ }^{2}$, M.

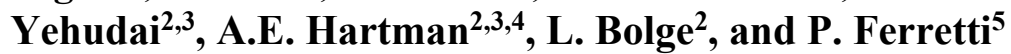 \\ ${ }^{1}$ Departament de Dinàmica de la Terra i de l'Oceà, Facultat de Ciències de la Terra, Universitat de \\ Barcelona, Barcelona, SPAIN. \\ mariajaume@ub.edu,lpena@ub.edu \\ ${ }^{2}$ Lamont-Doherty Earth Observatory of Columbia University, Palisades, NY, USA \\ steveg@ldeo.columbia.edu,bolge@ldeo.columbia.edu,knudsonk@gmail.com \\ ${ }^{3}$ Department of Earth and Environmental Sciences, Columbia University, NY, USA \\ jk3652@columbia.edu,my2430@columbia.edu \\ ${ }^{4}$ Department of Analytical Services, Agricultural Experiment Station Chemical Laboratories, \\ University of Missouri, Columbia, MO, USA \\ ahartman@missouri.edu \\ ${ }^{5}$ Dipartimento di Scienze Ambientali, Informatica e Statistica, Università Ca’ Foscari Venezia, \\ Venice, ITALY \\ patrizia.ferretti@unive.it
}

\begin{abstract}
The formation of North Atlantic Deep Water (NADW) determines the vigor of Atlantic Meridional Overturning Circulation (AMOC), which is key in redistributing heat across the globe, ultimately affecting global climate ${ }^{(1)}$. ODP Site $1063(4584 \mathrm{~m})$ in the mixing zone between NADW and Antarctic Bottom Water (AABW), on the Bermuda Rise, is seemingly ideal to study the relationship between ocean circulation and climate. Our new $\mathrm{Nd}$ isotope record at that site covers glacial-interglacial cycles extending to $\sim 1 \mathrm{Ma}$. The data shows $\mathrm{Nd}$ isotope ratios during parts of interglacials that are much lower than present day NADW. However, shallower DSDP Site 607 (3427 m), which we interpret as representing the deep North Atlantic ${ }^{(2,3)}$, displays interglacial $\mathrm{Nd}$ isotope values that are similar to modern NADW over the same time interval ${ }^{(4,5)}$. We conclude that, while glacial $\mathrm{Nd}$ isotope ratios at Site 1063 represent water mass mixing, interglacial values do not fully represent the North Atlantic endmember of the AMOC. We infer that the low Nd-isotope ratios in the deep Bermuda Rise during interglacials are consequence of regional processes of particle-seawater exchange derived from the arrival of freshly ground bedrock from the Canadian shield to the North Atlantic during major ice sheet retreats; the input of this poorly weathered material results on a deep, regionally constrained layer of seawater that is tagged with extreme $\mathrm{Nd}$ isotope signature not representative of the $\mathrm{AMOC}^{(6,7)}$. We suggest that the development of a benthic nepheloid layer (BNL), subject to the behavior of a deep-recirculating gyre system regulated by the interaction of the Gulf Stream and the deep western boundary current ${ }^{(8)}$, facilitates the
\end{abstract}


periodical masking of the deep Atlantic Nd isotope signature at Site 1063. The non-continuity of the masking allows for an speculation on how the deep-recirculating gyre system might have changed over the last $\sim 1$ Ma glacial-to-interglacial cycles.

Key words: Neodymium isotopes, deep Bermuda Rise, Benthic Nepheloid Layer, Early Middle Pleistocene

\section{References}

(1) Broecker, W. S. (1991). The great ocean conveyor. Oceanography, 4(2), 79-89.

(2) Raymo, M. E., Ruddiman, W. F., Shackleton, N. J., \& Oppo, D. W. (1990). Evolution of Atlantic-Pacific $\delta^{13} \mathrm{C}$ gradients over the Last 2.5 My. Earth and Planetary Science Letters, 97(3-4), 353-368.

(3) Yehudai, M., Kim, J., Goldstein, S.L., Pena, L.D., Jaume-Seguí, M., Knudson, K., Bolge, L., Ford, H., \& Raymo, M. (in prep). Neodymium isotope data from ODP Site 926. Interdisciplinary Earth Data Alliance (IEDA).

(4) Kim, J., Goldstein, S.L., Pena, L.D., Jaume-Seguí, M., Knudson, K., Yehudai, M., Bolge, L., Ford, H., \& Raymo, M. (in prep). Neodymium isotope data from DSDP Site 607. Interdisciplinary Earth Data Alliance (IEDA)

(5) Lambelet, M., van de Flierdt, T., Crocket, K., Rehkämper, M., Kreissig, K., Coles, B., et al. (2016). Neodymium isotopic composition and concentration in the western North Atlantic Ocean: Results from the GEOTRACES GA02 section. Geochimica et Cosmochimica Acta, 177(15), 1-29.

(6) Howe, J. N. W., Piotrowski, A. M., \& Rennie, V. C. F. (2016). Abyssal origin for the early Holocene pulse of unradiogenic neodymium isotopes in Atlantic seawater. Geology, 44(10), 831-834.

(7) Pöppelmeier, F., Gutjahr, M., Blaser, P., Keigwin, L. D., \& Lippold, J. (2018). Origin of Abyssal NW Atlantic water masses since the Last Glacial Maximum. Paleoceanography and Paleoclimatology, 33(5), 530-543.

(8) Gardner, W. D., Tucholke, B. E., Richardson, M. J., \& Biscaye, P. E. (2017). Benthic storms, nepheloid layers, and linkage with upper ocean dynamics in the western North Atlantic. Marine Geology, 385, 304327. 


\title{
DAY/NIGHT CYCLING OF VOC IN AND AROUND A PATCH OF THE CORAL ACROPORA PULCHRA
}

\author{
M. Masdeu-Navarro*1 , S.G. Gardner ${ }^{2}$, M. Cabrera ${ }^{1}$, P. Rodríguez-Ros ${ }^{1}$, C. Marrasé ${ }^{1}$ \\ and R. Simó ${ }^{1}$ \\ ${ }^{1}$ Institut de Ciències del Mar, Barcelona, SPAIN. \\ masdeu@icm.csic.es, cabrera@icm.csic.es,pros@icm.csic.es, celia@icm.csic.es, \\ rsimo@icm.csic.es \\ ${ }^{2}$ Biological Sciences South, UNSW, Kensigton, AUSTRALIA. \\ s.gardner@unsw.edu.au
}

\begin{abstract}
Biogenic Volatile Organic Compounds (VOCs) are essential constituents of marine ecosystems, where they are sources of atmospheric reactivity, indicators of the ecosystem state, and chemical cues for organism-organism communication. Most of VOCs result from photobiological and photochemical processes; however, their light-driven dynamics and short-term variability still are poorly known.

We studied the variability of DMS, isoprene, $\mathrm{CH}_{3} \mathrm{I}$ and bromomethanes across day/night cycle in scleractinian coral Acropora pulchra in Mo'orea, French Polynesia. We measured VOCs at two heights among the branches of the coral and $1 \mathrm{~m}$ down-current during 24-25 April 2018 every 6 hours. According to concentration gradients, the coral holobiont produced DMS and $\mathrm{CH}_{3} \mathrm{I}$, particularly during the day, and did not produce isoprene and bromomethanes. We also collected samples for RNA metabarcoding to determine if differences in VOCs are related to differences in the taxonomic composition of the microbial community.
\end{abstract}

Key words: Volatile Organic Compounds, DMS, Scleractinian corals, Coral reef, Isoprene 


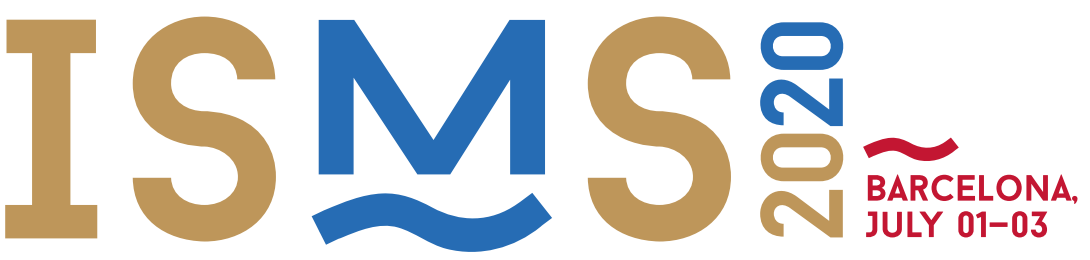

VII INTERNATIONAL SYMPOSIUM ON MARINE SCIENCES BARCELONA
JULY 01-03
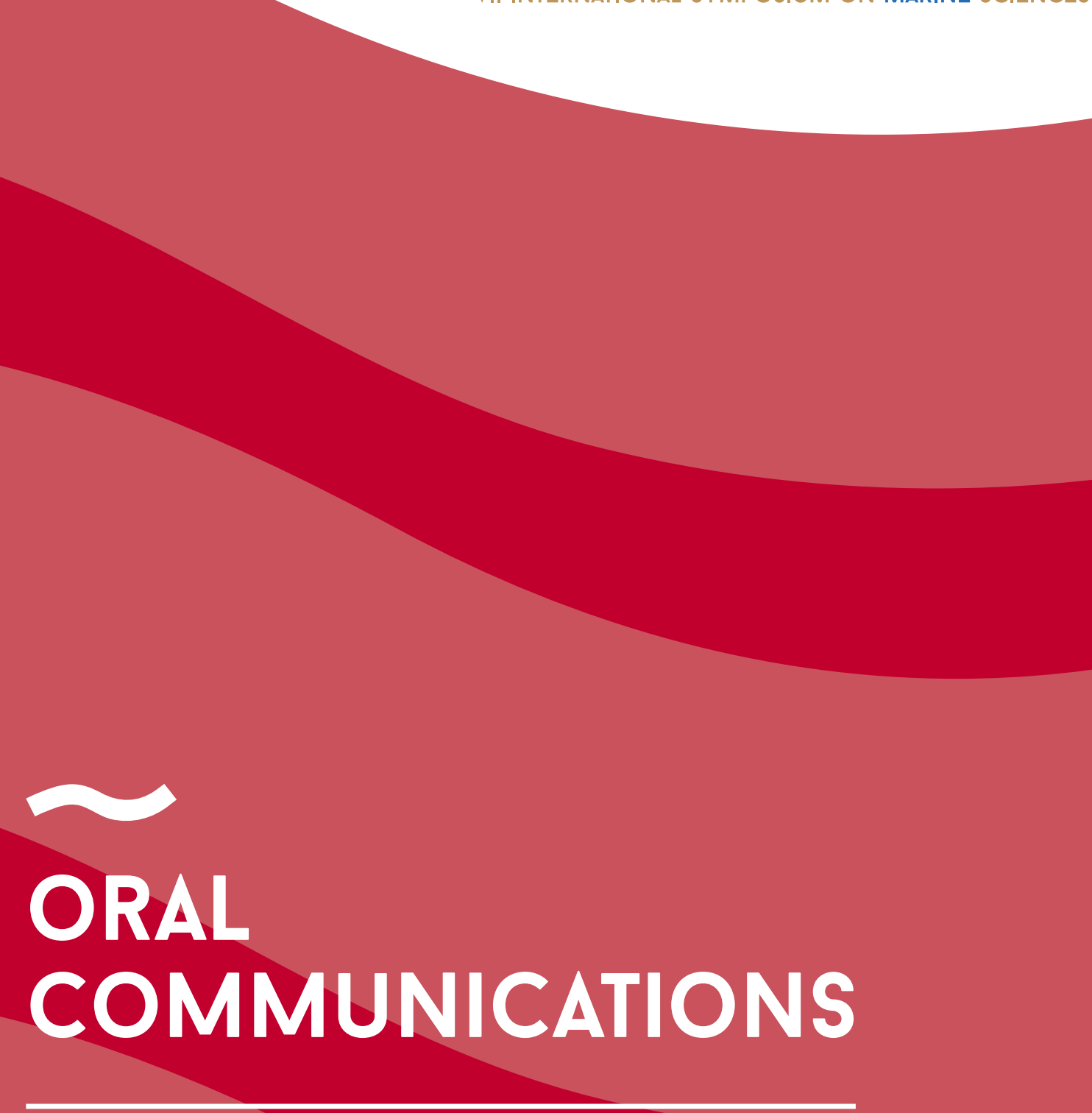

\section{CHEMICAL}

OCEANOGRAPHY AND BIOGEOCHEMISTRY 


\title{
THE USE OF A CITIZEN SCIENCE TOOL (iMEDJELLY App) TO DELIVER FIRST AID PROTOCOLS FOR MEDITERRANEAN JELLYFISH STINGS
}

\author{
A. Ballesteros ${ }^{* 1}$, M. Marambio ${ }^{1}$, V. Fuentes ${ }^{1}$ and J.-M. Gili ${ }^{1}$ \\ ${ }^{1}$ Department of Marine Biology and Oceanography, Institute of Marine Sciences (ICM-CSIC), \\ Passeig Marítim de la Barceloneta, 37-49. E-08003 Barcelona, SPAIN. \\ ballesteros@icm.csic.es,marambio@icm.csic.es,vfuentes@icm.csic.es, gili@icm.csic.es
}

\begin{abstract}
Jellyfish presence in coastal areas generates social alarm and negative impact on the health of beach users. As the impact and consequences are increasing lately, researchers from ICM-CSIC of Barcelona developed the mobile application iMedJelly, a citizen science tool that gives a daily real-time report about the presence of jellyfish on the beaches, and also informs about the species and how to react in case of sting.
\end{abstract}

To ensure a proper use of the App, training sessions to the rescue services were carried out along the Catalan coast. One of the weakest points identified during these sessions was the lack of information and ignorance about first-aid protocols against jellyfish stings. Therefore, some effort was focused in the improvement of the current protocols through evaluation of the response of distinctive jellyfish's stinging cells (nematocysts) against different compounds usually used after jellyfish stings (vinegar, freshwater, seawater) in Pelagia noctiluca, a Mediterranean schyphomedusa, and Carybdea marsupialis, a Mediterranean cubomedusa.

The nematocyst response to compounds was tested in live tentacles using the Tentacle Solution Assay methodology (Yanagihara et al. 2016). Results were different in both species, highlighting the importance of knowing and applying the correct rinse solution depending on what type of jellyfish species was the responsible one.

These results were essential to update protocols and refer to them as species-specific firstaid protocols. Correct information and use of jellyfish sting first-aid protocols was identified as one of the most relevant mitigation measures concerning the impact of jellyfish presence in coastal areas. The updated protocols are included in a special section of the iMedJelly App for free use by citizens and rescue services where, at the same time, direct contact with the research team is possible in case of doubts on jellyfish, protocols or presence of severe cases of sting during the summer season.

Key words: iMedJelly App, Citizen science, Nematocysts, First-aid protocols, Beach users. 


\section{References:}

Yanagihara, A. A., Wilcox, C., King, R., Hurwitz, K. and Castelfranco, A. M. (2016). Experimental assays to assess the efficacy of vinegar and other topical first-aid approaches on cubozoan (Alatina alata) tentacle firing and venom toxicity. Toxins, 8 (1), 19. 


\section{OBSERVADORES DEL MAR - A MARINE CITIZEN SCIENCE PLATFORM WORKING FOR A HEALTHY OCEAN}

J. Garrabou*1, G. Agell ${ }^{2}$, Ò. Chic ${ }^{3}$, M. García ${ }^{2}$, P. López-Sendino ${ }^{1}$, M. Marambio ${ }^{1}$, M. Vicioso ${ }^{3}$, V. Fuentes ${ }^{1}$, F. Tomas ${ }^{4}$, P. Balistreri ${ }^{5}$, E. Ballesteros ${ }^{2}$, E. Cebrián ${ }^{7}$,

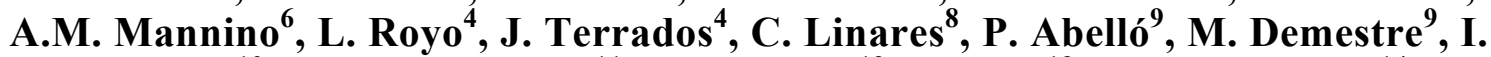
Mazarrasa $^{10}$, M. Corsini-Foka ${ }^{11}$, J.A. Cuesta ${ }^{12}$, D. Díaz ${ }^{13}$, P.C. Rodriguez ${ }^{14}$, J. Boada $^{8}$, T. Alcoverro ${ }^{2}$, B. Hereu ${ }^{8}$, M. Planas ${ }^{15}$, I. Castejón ${ }^{4}$, J. HernándezUrcera $^{15}$, B. Morales ${ }^{4}$, L.F. Ruiz-Orejón ${ }^{16}$, I.E. Hendriks ${ }^{17}$, E. Álvarez ${ }^{13}, M$. Vázquez-Luis $^{13}$, S. Deudero ${ }^{13}$, E. Azzurro ${ }^{18}$, F. Maynou ${ }^{9}$, F. Tiralongo ${ }^{19}$, A.

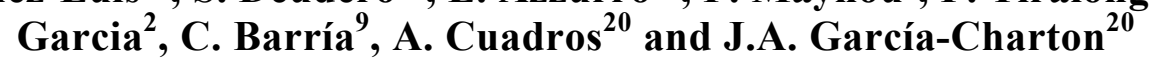

${ }^{1}$ Department of Marine Biology and Oceanography, Institute of Marine Sciences, Barcelona, SPAIN.

garrabou@icm.csic.es,plopez@icm.csic.es,marambio@icm.csic.es,vfuentes@icm.csic.es

${ }^{2}$ Department of Marine Ecology, Blanes Centre for Advanced Studies, Blanes, SPAIN. gemma@ceab.csic.es.maria@ceab.csic.es,kike@ceab.csic.es,teresa@ceab.csic.es, tonigr@ceab.csic.es

${ }^{3}$ Department of Technical Services, Institute of Marine Sciences, Barcelona, SPAIN. ochic@icm.csic.es,mvcasanal@icm.csic.es

${ }^{4}$ Department of Marine Ecology, Mediterranean Institute for Advanced Studies, Mallorca, SPAIN. fiona@imedea.uib-csic.es,laura.royo@yahoo.es,terrados@imedea.uib-csic.es, icastejon@imedea.uib-csic.es, beatriz@imedea.uib-csic.es

${ }^{5}$ Vicolo Giotto 6, 91023 Favignana TP, Island of Favignana, ITALY. requin.blanc@hotmail.it

${ }^{6}$ Department of Biological, Chemical and Pharmaceutical Sciences and Technology, University of Palermo, Palermo, ITALY. annamaria.mannino@unipa.it

${ }^{7}$ Department of Environmental Sciences, Universitat de Girona, Girona, SPAIN. emma.cebrian@udg.edu

${ }^{8}$ Department of Evolutionary Biology, Ecology and Environmental Sciences, Universitat de Barcelona, Barcelona, SPAIN. cristinalinares@ub.edu,jboada@ceab.csic.es,hereu@ub.edu

${ }^{9}$ Department of Renewable Marine Resources, Institute of Marine Sciences, Barcelona, SPAIN. pabello@icm.csic.es,montse@icm.csic.es,maynouf@icm.csic.es,barria@icm.csic.es

${ }^{10}$ IHCantabria-Instituto de Hidráulica Ambiental de la Universidad de Cantabria, Santander, SPAIN. ines.mazarrasa@unican.es

${ }^{11}$ Institut of Oceanography/Hydrobiological Station of Rhodes, Hellenic Centre for Marine Science, Anávyssos, GREECE. mcorsini@hcmr.gr

${ }^{12}$ Department of Ecology and Coastal Management, Institute of Marine Sciences of Andalusia, Cádiz, SPAIN.

jose.cuesta@icman.csic.es 


\author{
${ }^{13}$ Spanish Institute of Oceanography, Mallorca, SPAIN. \\ david.diaz@ieo.es,elvira.alvarez@ieo.es,maite.vazquez@ieo.es,salud.deudero@ieo.es \\ ${ }^{14}$ National Museum of Natural Sciences-CSIC, Madrid, SPAIN. \\ paularodriguezflores@gmail.com \\ ${ }^{15}$ Department of Ecology and Marine Resources, Marine Research Institute, Vigo, SPAIN. \\ mplanas@iim.csic.es, jurcera@iim.csic.es \\ ${ }^{16}$ Independent, SPAIN. \\ luisf.ruizorejon@gmail.com \\ ${ }^{17}$ Department of Oceanography and Global Change, Mediterranean Institute for Advanced Studies, \\ Mallorca, SPAIN. \\ iris@imedea.uib-csic.es, terradosimedea.uib-csic.es \\ ${ }^{18}$ Istituto per le Risorse Biologiche e le Biotechnologie Marine, Italian National Research Council, \\ Rome, ITALY. \\ eazzurro@gmail.com \\ ${ }^{19}$ Ente Fauna Marina Mediterranea, Avola, ITALY. \\ fra.tiralongo@hotmail.it \\ ${ }^{20}$ Department of Ecology and Hydrology, Universidad de Murcia, Murcia, SPAIN. \\ amalia.cuadros1@gmail.com,jcharton@um.es
}

\begin{abstract}
Observadores del Mar is a marine citizen science platform launched in 2012 devoted to enhancing the understanding of the conservation status of marine ecosystems. The platform hosts different projects reporting information on two main topics: i) biodiversity data focusing mainly on species distribution and abundance, and ii) the impacts of anthropogenic activities, including both the occurrence of episodic events (e.g. jellyfish blooms) and associated mid- to long-term changes (e.g. colonization of invasive species).
\end{abstract}

At present Observadores del Mar includes 13 projects covering 8 main taxa: corals, jellyfishes, decapod crustaceans, fishes, seaweeds, seagrasses, seabirds and molluscs, in addition to two projects focused on marine litter. The platform provides information on the rationale, methods and materials for each project. A new web interface was designed to facilitate data entry and enhance data validation by scientists. Moreover, different functionalities were developed to build the Observadores del Mar community. Beyond the web tools, Observadores del Mar has been also very active in promoting citizen science events, training sessions for recreational divers, schools and the general public.

Currently the Observadores del Mar platform has more than 2400 volunteers, 240 entities (including more than 40 schools) and 60 scientists from more than 40 research institutions and universities. Almost 12000 observations have been already collected resulting in the publication and presentation of more than 20 scientific papers and communications. The major findings have been new records of introduced and invasive species, tracking the spread of novel pen shell mortality outbreak in the Mediterranean Sea and monitoring microplastic concentrations on beaches. Furthermore, some of the information gathered was transferred to public administrations to inform management and action plans at different levels. In conclusion, Observadores del Mar is providing reliable and relevant scientific information while allowing citizens to collaborate and get involved in marine sciences, thus facilitating the interaction among different stakeholders aiming to work for a healthy ocean.

Key words: Marine citizen science, Conservation biology, Climate change, Public engagement 
Acknowledgments: Data gained thanks to the alliance of Observadores del Mar with the LIFE IP INTEMARES project, which is coordinated by Biodiversity Foundation of the Spanish Ministry for Ecological Transition and Demographic Challenge. We thank also MPA-ENGAGE, a Interreg Med Programme co-funded by the European Regional Development Fund, and Ojo a las Invasoras, funded by FECYT. 


\title{
ENVIRONMENTAL IMPACTS AND THEIR SOCIAL PERCEPTION IN LAS CANTERAS BEACH: A TOOL FOR SUSTAINABLE MANAGEMENT
}

\author{
Kevin Ugwu Hernández*1, Fernando Tuya Cortés ${ }^{2}$ and Carolina Peña Alonso $^{3}$ \\ ${ }^{1}$ Oceanography Master, ULPGC, Las Palmas of Gran Canaria, SPAIN. \\ kevin.ugwu101@alu.ulpgc.es \\ ${ }^{2}$ Biology Department, ECOAQUA, ULPGC, Las Palmas of Gran Canaria, SPAIN. \\ fernando.tuya@ulpgc.es \\ ${ }^{3}$ Physical Geography Department, IOCAG, ULPGC, Las Palmas of Gran Canaria, SPAIN. \\ carolina.pena@ulpgc.es
}

\begin{abstract}
Environmental impacts affect ecosystems and society ${ }^{1}$. Social perception has been placed as one of the most useful instruments to determine the knowledge of a population towards a range of impacts ${ }^{2}$. The present communication uses these study methods in Las Canteras beach, in Las Palmas de Gran Canaria, to describe social perception of the environmental impacts, here categorized at global and local scales. Social perception was analyzed from surveys for beach users, collected on the beach, to determine if socialprofile (sex, age, level of studies and economic level) is related with the perception of the different environmental impacts. The results show that global impacts get higher scores than local impacts; overall, the social perception of the impacts is high. Also, results indicate that perceived impacts are independent of the social profile. Therefore, this research allows understanding social behaviors on the beach, and also implementing new indicators that improve sustainability in the management of Las Canteras beach.
\end{abstract}

Key words: Human impacts, Social, Perception, Sustainability, Las Canteras beach.

\section{References:}

1. Martínez Martínez, J., Casas Ripoll, D., Calles García, S., Medina Comas, A., Ramos Betancor, C. J. (2016). The environmental cost of social and economic progress of some beaches, with their dunes, which were virgins in the next yesterday: Evaluation of Environmental Impacts inherited by the use and enjoyment of the coastal system of El Inglés-Maspalomas (Gran Canaria Island, Spain). Coastline Planning and Management: Las Palmas of Gran Canaria.

2. Ortega García, M. K., Tuya Cortés, F., Espino Rodríguez, F. 2017. Social perception of the conservation and historical trends of the Cymodocea nodosa meadows on the island of Gran Canaria (Master thesis). Las Palmas of Gran Canaria University, Spain. 


\title{
MAXIMIZING ENGAGEMENT IN CITIZEN SCIENCE, MOVING TO SEVENTH LEVEL
}

\author{
Sonia Liñán*1, Karen Adriana Soacha ${ }^{1}$, Andrea Comaposada ${ }^{2}$, Patricia Panadero ${ }^{2}$ \\ and Jaume Piera ${ }^{1}$ \\ ${ }^{1}$ Oceanografía Física y Tecnológica, Institut de Ciències del Mar (ICM-CSIC), Barcelona, \\ ESPAÑA \\ slinan@cos4cloud-eosc.eu,soacha@icm.csic.es,jpiera@icm.csic.es \\ ${ }^{2}$ Anèl-lides serveis ambientals marins, Barcelona, ESPAÑA \\ andrea@anellides.com,info@anellides.com
}

\begin{abstract}
We need new approaches to get data that help us to make a difference in safeguarding and understanding marine systems. But new discoveries require a lot more eyes, ears and perspectives than scientists currently have. Citizen science provides those eyes and ears and allows collaboration between citizens and scientists that can catapult scientific research. However, it faces a big challenge: How do we keep a high engagement level and maintain citizen participation over time? To achieve that, the citizen must experience a direct alignment of the project with their personal beliefs leading to loyalty and action without incentive, what is known as the Seventh Level of Engagement (Slaving 2019).
\end{abstract}

Natusfera is a biodiversity citizen observatory with high citizen engagement values where citizens can upload their photographs and provide data on location and taxonomy. In just 3 years it has gained more than 12,000 users and over 230,000 observations from almost 12,000 species. Natusfera is based on three main principles: 1) Society: a sense of belonging to a community; 2) Bottom-up strategy: encouraging participants to create their own projects based on personal interests or concerns; 3) Curation community: everyone could contribute with the species identification, not only taxonomist. On top of that, Natusfera uses an engaging strategy that combines a Hook model (trigger, action, reward) with a Growth Loop (engagement and dissemination activities). All this forms a great scenario to achieve the Seventh Level of Engagement.

We will share the analysis, lessons learned and key aspects to take into account in an engagement and communication strategy based on the case study of the 'Biomarato Marina', a dedicated 24 hours effort that has been involving more than 200 citizens and scientists in Barcelona since 2018 and that annually collects hundreds of open biodiversity data through Natusfera.

Key words: citizen engagement, citizen science, marine biodiversity, bioblitz, Natusfera 


\section{Acknowledgments:}

Cos4Cloud has received funding from the European Union's Horizon 2020 research and innovation programme under grant agreement No 863463.

\section{References:}

Slaving, A (2019). The Seventh Level: Transform Your Business Through Meaningful Engagement with Your Customers and Employees. Lioncrest Publishing. 


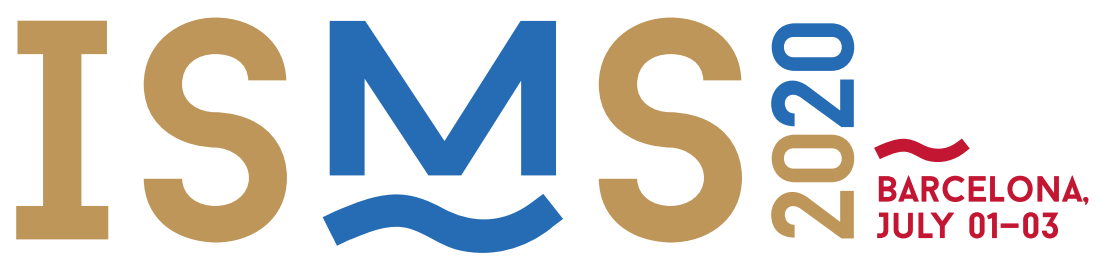

VII INTERNATIONAL SYMPOSIUM ON MARINE SCIENCES BULY 01-03

\section{ORAL COMMUNICATIONS}

\section{CLIMATE CHANGE AND THE OCEAN}




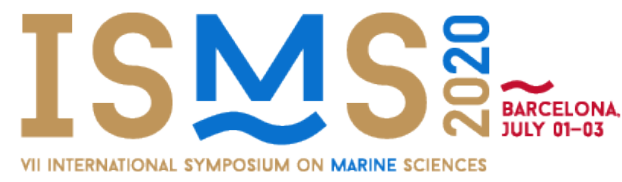

VII International Symposium on Marine Sciences

ISMS 2020

Barcelona (Spain), $1^{\text {st }}-3^{r d}$ July 2020

\title{
MARINE FOREST LOSS IN MADEIRA ARCHIPELAGO: AN HISTORICAL REVIEW
}

\author{
A. Bernal ${ }^{* 1}$, E. Cacabelos ${ }^{1}$ and I. Gestoso ${ }^{1,2}$ \\ ${ }^{1}$ MARE - Marine and Environmental Sciences Centre, Agência Regional para o Desenvolvimento \\ da Investigação Tecnologia e Inovação (ARDITI), Funchal, Madeira, PORTUGAL. \\ alejandro.bernal@mare-centre.pt, ecacabelos@mare-centre.pt,igestoso@mare-centre.pt \\ ${ }^{2}$ Smithsonian Environmental Research Center, Edgewater, MD 21037, USA.
}

\begin{abstract}
Marine forests play a key ecological and economic role in coastal habitats as dominant primary producers, providing food and structural habitat for diverse fauna and flora (Bertness and Callaway, 1994; Molina-Montenegro et al., 2005; Scherner et al., 2013). Canopy-forming algae become therefore one of the key biological elements to be considered in the determination of the ecological quality status of coastal water bodies (Paola and Pinedo, 2007). Up to date, insufficient information exists to allow a precise estimation of the status of the marine forests in the archipelago of Madeira in the recent past. In this context, the aim of this work is to collect information from diverse sources (bibliographic resources, interviews) to characterize the state of benthic habitats of the archipelago in the last decades, as well as their current state. Accordingly to the first appointments, checklists and records of species on algal communities of Madeira published as early as the 18th century (Piccone, 1884), together with popular knowledge and perception of regional fishermen, macroalgae forests were known to exist in the archipelago decades ago. The absence of canopy-forming algae in spots of Madeira and the presence of numerous sea urchins was already cited in the mid-19th century (Levring, 1974). Currently, the benthic nearshore ecosystem of Madeira Island is mainly dominated by crustose algal communities, turf-forming algae and sea urchins (Sangil et al., 2018). Canopy-forming algae have been reduced to specific points and rockpools, while in the best-preserved islands of the archipelago, Ilhas Selvagens, erect algae have a greater contribution (Friedlander et al., 2017). Therefore, it seems macroalgae forests are in decline, maybe due to the growing and intense human activities near the coast of Madeira during the last decades. The existence of well-preserved macroalgae forest in low impacted islands suppose a baseline for the knowledge of how the Madeira's macroalgae forests were probably in the past, and a bit of hope for trial restoration actions in the future.
\end{abstract}

Key words: Macroalgal, Canopy-forming algae, Human impact, Madeiran Archipelago

Acknowledgments: Acknowledgement to ARDITI - Agência Regional para o Desenvolvimento e Tecnologia under the scope of the Projects M1420-09-5369-000002 PhD Studentship and M1420-09-5369-FSE-000001. 


\section{References:}

Bertness, M.D. and Callaway, R. (1994). Positive interactions in communities. Trends in Ecology \& Evolution 9 (5), 191-193.

Friedlander, A.M., Ballesteros, E., Clemente, S., Gonçalves, E.J., Estep, A., Rose, P. and Sala, E. (2017). Contrasts in the marine ecosystem of two Macaronesian islands: A comparison between the remote Selvagens Reserve and Madeira Island. PloS One 12 (11), e0187935.

Levring, T. (1974). The marine algae of the Archipelago of Madeira. Boletim do Museu Municipal do Funchal $28,5-111$

Molina-Montenegro, M.A., Muñoz, A.A., Badano, E.I., Morales, B.W., Fuentes, K.M. and Cavieres, L.A. (2005). Positive associations between macroalgal species in a rocky intertidal zone and their effects on the physiological performance of Ulva lactuca. Marine Ecology Progress Series 292, 173-180.

Paola, M. and Pinedo, S. (2007). Rocky-shore communities as indicators of water quality: A case study in the Northwestern Mediterranean. Marine Pollution Bulletin 55, 126-135.

Piccone, A. (1884). Crociera del Corsaro alle isole Madera e Canarie del capitano Enrico D'Albertis: Alghe. Tip. de R. Istituto sordo-muti.

Sangil, C., Martins, G.M., Hernández, J.C., Alves, F., Neto, A.I., Ribeiro, C., ... and Titley, I. (2018). Shallow subtidal macroalgae in the North-eastern Atlantic archipelagos (Macaronesian region): a spatial approach to community structure. European Journal of Phycology 53 (1), 83-98.

Scherner, F., Horta, P.A., de Oliveira, E.C., Simonassi, J.C., Hall-Spencer, J.M., Chow, F., ... and Pereira, S.M.B. (2013). Coastal urbanization leads to remarkable seaweed species loss and community shifts along the SW Atlantic. Marine Pollution Bulletin 76 (1-2), 106-115. 


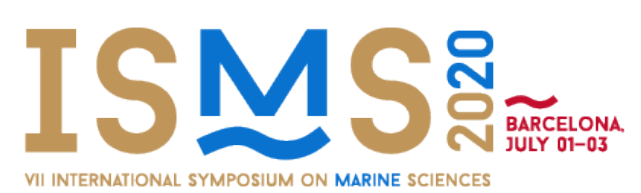

VII International Symposium on Marine Sciences

ISMS 2020

Barcelona (Spain), $1^{\text {st }}-3^{\text {rd }}$ July 2020

\section{PASSENGERS TO THE COLD: INVASIVE MARINE SPECIES DISCOVERED ON NON-NATIVE KELP RAFTS IN THE WARMEST ANTARCTIC ISLAND}

\author{
Conxita Avila**1, Carlos Angulo-Preckler ${ }^{1}$, Rafael Pablo Martín-Martín ${ }^{1}$, Blanca \\ Figuerola $^{2}$, Huw J Griffiths ${ }^{3}$, Catherine Louise Waller ${ }^{4}$ \\ ${ }^{1}$ BEECA Department (Invertebrates), Faculty of Biology and IrBIO, Barcelona, CATALONIA. \\ conxita.avila@ub.edu,carlospreckler@hotmail.com,ginkopsida@gmail.com \\ ${ }^{2}$ ICM-CSIC, Barcelona, Catalonia \\ bfiguerola@gmail.com \\ ${ }^{3}$ British Antarctic Survey, Cambridge, England \\ hjg@bas.ac.uk \\ ${ }^{4}$ University of Hull, Department of Biological and Marine Sciences, Hull, UK \\ C.L.Waller@hull.ac.uk
}

\begin{abstract}
Antarctic shallow coastal marine communities were long thought to be isolated from their nearest neighbours by hundreds of kilometres of deep ocean and the Antarctic Circumpolar Current. The discovery of non-native kelp washed up on Antarctic beaches led us to question the permeability of these barriers to species dispersal. Over 70 million kelp rafts are afloat in the Southern Ocean at any one time. These living, floating islands can play host to a range of passenger species from both their original coastal location and those picked in the open ocean. Driven by winds, currents and storms towards the coast of the continent, these rafts are often cited as theoretical vectors for the introduction of new species into Antarctica and the sub-Antarctic islands. We found non-native kelps, with a wide range of "hitchhiking" passenger organisms, on an Antarctic beach inside the flooded caldera of an active volcanic island. This is the first evidence of non-native species reaching the Antarctic continent alive on kelp rafts. One passenger species, the bryozoan Membranipora membranacea, is a notorious invasive and ecologically harmful species elsewhere in the world and this is its only record from Antarctica. The caldera of Deception Island provides considerably milder conditions than the frigid surrounding waters and is an ideal location for newly introduced species to become established. These findings help to explain many of the biogeographic patterns and connections we currently see in the Southern Ocean, however, with the impacts of climate change in the region we are likely to see an increase in the range and number of organisms capable of surviving both the long journey and becoming successfully established.
\end{abstract}

Key words: Marine ecology, Climate change, Invasive species, Membranipora, macroalgae

Acknowledgments: This study has been developed within the frame of the BLUEBIO project (CTM2016-78901/ANT). This is an AntEco (SCAR) contribution. 


\title{
INFLUENCE OF THE MOST IMPORTANT RIVER PLUMES ON SEA SURFACE TEMPERATURE PATTERNS
}

\author{
D. Fernández-Nóvoa**1, X. Costoya ${ }^{2}$, M. deCastro ${ }^{3}$, M. Gómez-Gesteira ${ }^{4}$ \\ ${ }^{1,3,4}$ Environmental Physics Laboratory (EPhysLab), CIM-UVIGO, University of Vigo, Ourense, \\ SPAIN. \\ diefernandez@uvigo.es,mdecastro@uvigo.es,mggesteira@uvigo.es \\ ${ }^{2}$ CRETUS Institute, Group of Nonlinear Physics, Department of Particle Physics, University of \\ Santiago de Compostela, Santiago de Compostela, SPAIN. \\ jorge.costoya.noguerol@usc.es
}

\begin{abstract}
Sea Surface Temperature (SST) has shown a strong warming trend since the 1980s due to the increase in the heat content of the Earth, which has been mainly absorbed by oceans (Levitus et al., 2012). Although warming was the dominant trend in all basins, there exist variations that depend on temporal and spatial scales. In this sense, coastal areas have shown high spatial heterogeneity over the last three decades (Lima and Wethey, 2012). One of the main factors contributing to this different coastal behaviour is based on the different thermohaline conditions promoted by freshwater inputs (Costoya et al., 2016). On the one hand, some river plumes reinforce the adjacent oceanic warming (Materia et al., 2012), whereas on the other hand some river plumes are able to modulate or even reverse the generalized oceanic warming (White and Toumi, 2014). In this sense, the knowledge of systems and mechanisms able to modulate at certain extent the SST warming could be of a crucial importance in the current context of global warming. For that, the aim of this study is to investigate the SST evolution caused by the most important river plumes worldwide from 1982 to the present. First of all, the area more affected by each river plume was delimited using salinity data obtained from the NOAA World Ocean Atlas 2018 (WOA18). Then, the analysis of temperature patterns was carried out by means of SST data provided by the Advanced Very High Resolution Radiometer Optimum Interpolation Sea Surface Temperature (AVHRR-Only OISST $_{1 / 4}$ ). In general terms, most of the rivers analysed shown their capacity to modulate the warming observed in the adjacent oceanic areas.
\end{abstract}

Key words: River plumes, Sea Surface Temperature, Warming modulation.

Acknowledgments: This work was partially supported by Xunta de Galicia under the project "Programa de Consolidación e Estructuración de Unidades de Investigación Competitivas: Grupos de Referencia Competitiva (ED431C 2017/64-GRC)". 


\section{References:}

Costoya, X., Fernández-Nóvoa, D., deCastro, M., Santos, F., Lazure, P., and Gómez-Gesteira, M. (2016). Modulation of sea surface temperature warming in the Bay of Biscay by Loire and Gironde Rivers. Journal of Geophysical Research: Oceans, 121 (1), 966-979.

Levitus, S., et al. (2012). World ocean heat content and thermosteric sea level change (0-2000m), 1955-2010. Geophysical Research Letters, 39 (10), L10603.

Lima, F.P., and Wethey, D.S. (2012). Three decades of high-resolution coastal sea surface temperatures reveal more than warming. Nature Communications, 3 (1), 1-13.

Materia, S., Gualdi, S., Navarra, A., and Terray, L. (2012). The effect of Congo River freshwater discharge on Eastern Equatorial Atlantic climate variability. Climate dynamics, 29 (9-10), 2109-2125.

White, R.H., and Toumi, R. (2014). River flow and ocean temperatures: The Congo River. Journal of Geophysical Research: Oceans, 119 (4), 2501-2517. 


\title{
THE RE-ESTABLISHMENT OF THE SEDIMENTARY BALANCE AT MASPALOMAS DUNEFIELD. AN EXAMPLE OF ADAPTATION TO CLIMATE CHANGE
}

\author{
Casamayor M. ${ }^{1}$, Alonso I. *2, Rodriguez S. ${ }^{3}$ and Sánchez-García M.J. ${ }^{4}$ \\ 1, 2, 3,4 Instituto de Oceanografía y Cambio Global, Universidad de Las Palmas de Gran Canaria, \\ Las Palmas de Gran Canaria, Spain. \\ marionacasamayor@gmail.com; ignacio.alonso.bilbao@ulpgc.es; silvia.ccmar@gmail.com; \\ mariajose.sanchez@ulpgc.es
}

\begin{abstract}
Maspalomas is a coastal dunefield located at the south of Gran Canaria Island. It is a protected natural space mostly because of its singularity, since this is the only active dunefield in the island. Apart from that, Maspalomas is also a hot spot in tourism related issues, since the municipality of San Bartolomé de Tirajana, where Maspalomas is located, received more than two million tourists during 2019. The study area is very vulnerable. The average height of the interdune areas is only 1.3 m.a.m.s.l., and several studies have pointed out the scarcity of sediments in the dune field. This situation results from several factors. Among them, the urban development in the surrounding area is a key aspect, since the buildings have modified the wind field affecting the dunes and the aeolian transport has been reinforced. Furthermore, the sediment inputs towards the dunes are negligible compared to the outputs, which are mostly related to winds and south-westerly storms.

In this situation, the island administration has funded a pilot project (named MASDUNAS), whose aim is to re-establish the sedimentary balance within the area. The scientific monitoring of the project includes monthly DTMs with LiDAR data from UAV. As a result of the project $37,500 \mathrm{~m}^{3}$ of sand have been moved to the natural input area from the sector where the system losses material. A sedimentary ridge $830 \times 55 \times 0.75 \mathrm{~m}$ has been formed along El Inglés beach. This ridge is slowly feeding the dune system by aeolian transport, and it represents a defence against wave action and flooding. From these results it has been proposed to continue the movements of sand in the medium term to reinforce this ridge and to maintain the feeding of sand to the dunes. This project represents a perfect example of soft adaptation against climate change.
\end{abstract}

Key words: Dune management, Sea level rise, LiDAR, Gran Canaria.

Acknowledgments: Thanks are due to Cabildo de Gran Canaria for funding MASDUNAS project. 


\title{
IINFERRING DEGLACIAL VENTILATION AGES IN WESTERN MEDITERRANEAN WATERS USING COLD-WATER CORALS
}

\author{
M. de la Fuente *1, L. Skinner ${ }^{2}$, A. Sadekov³, P. Scott ${ }^{3}$, C. Lo Iacono ${ }^{4}$, G. \\ Corbera $^{5}$, G. Ercilla ${ }^{4}$, E. d'Acremont ${ }^{6}$, L. Somoza ${ }^{7}$, F.J. González Sanz ${ }^{7}$, L.D. \\ Pena $^{1}$, P. Zhang ${ }^{8}$, H. Cheng ${ }^{8}$ and I. Cacho ${ }^{1}$ \\ ${ }^{1}$ Departament de Dinàmica de la Terra i de l'Oceà, Facultat de Ciències de la Terra, Universitat de \\ Barcelona, Barcelona, SPAIN. \\ mdelafuente@ub.edu,lpena@ub.edu,icacho@ub.edu \\ ${ }^{2}$ Department of Earth Sciences, University of Cambridge, Cambridge, UK. \\ luke00@esc.cam.ac.uk \\ ${ }^{3}$ ARC Centre of Excellence for Coral Reef Studies, University of Western Australia, Perth, \\ AUSTRALIA. \\ Aleksey.Sadekov@uwa.edu.au,pete.scott@uwa.edu.au \\ ${ }^{4}$ Institut de Ciències del Mar (ICM-CSIC), Barcelona, SPAIN. \\ loiacono@icm.csic.es,gemma@icm.csic.es \\ ${ }^{5}$ National Oceanography Centre, University of Southampton, Southampton, UK. \\ gc8g14@soton.ac.uk \\ ${ }^{6}$, Institut des Sciences de la Terre, Sorbonne Université, CNRS-INSU, Paris, FRANCE. \\ elia.dacremont@sorbonne-universite.fr \\ ${ }^{7}$ Instituto Geológico y Minero de España (IGME), Madrid, SPAIN. \\ l.somoza@igme.es,fj.gonzalez@igme.es \\ ${ }^{8}$ Xi' an Jiaotong University, Xi'an, CHINA. \\ zhangpu357@xjtu.edu.cn,cheng021@xjtu.edu.cn
}

\begin{abstract}
Mediterranean Outflow Water (MOW) acts as a net source of salt and heat into North Atlantic intermediate depths that ultimately contributes to the Atlantic Meridional Overturning Circulation, and it has been hypothesised that MOW variability might influence global climate. Although several studies have documented major glacialinterglacial changes in deep- and intermediate Mediterranean circulation patterns, little is known about associated impacts on MOW properties, in particular its residence time and geochemical signature. Using cold-water coral sets from along the pre- and MOW-path from the Alboran Sea to the northern Galician Bank we aim to identify changes in both the ventilation state of the water masses flowing out of the Mediterranean and the distribution of coral growth through paired Uranium-series and AMS radiocarbon ages complemented by trace element measurements in benthic foraminifera.
\end{abstract}

Our results show a particular spatio-temporal coral distribution with glacial presence only at the deepest sites of the Gulf of Cadiz $(\sim 1000 \mathrm{~m})$, followed by $\sim 300 \mathrm{~m}$ Western 
Mediterranean (WMed) coral appearance across the deglaciation/mid Holocene (14-4kyr), to end with a proliferation at the Strait of Gibraltar and Galicia Bank from 6kyr towards the present. We hypothesise 1) that $\sim 300 \mathrm{~m}$ WMed area might have been bathed in Atlantic waters inflow during the glacial due to sea-level drop, returning to Levantine Intermediate Water influence over the deglaciation, and 2) that MOW reached deeper areas outside of the Mediterranean Sea in the Gulf of Cadiz during the glacial. Regarding the reservoir age, a little $\sim 300 \mathrm{yr}$ change is observed at the WMed at $150-450 \mathrm{~m}$ when corals appear at the Bølling-Allerød, but in synchrony with significant changes in hydrographical parameters. Overall, our results suggest a water mass reorganization at the surface-intermediate layer of the WMed during the deglaciation/early Holocene, that need to be further explored through $\mathrm{Nd}$ isotope analysis and trace elements beyond the deglaciation.

Key words: MOW, Deep-sea corals, Ventilation ages, Deglaciation 


\title{
PROXY VALIDATION WITH PRESENT-DAY DATA OF DEEP- WATER FORMATION DURING THE LAST 2500 YEARS IN THE NORTHWESTERN MEDITERRANEAN SEA
}

\author{
M. Cisneros* ${ }^{* 1}$, I. Cacho ${ }^{1}$, J. Frigola ${ }^{1}$, A. Sanchez-Vidal ${ }^{1}$, A. Calafat ${ }^{1}$, R. Pedrosa- \\ Pàmies $^{1,2}$, A. Rumín-Caparrós ${ }^{1}$ and M. Canals ${ }^{1}$ \\ ${ }^{1}$ GRC Geociències Marines, Departament de Dinàmica de la Terra i de l'Oceà, Facultat de \\ Ciències de la Terra, Universitat de Barcelona, Barcelona, Spain \\ mcisneros@ub.edu, icacho@ub.edu, anna.sanchez@ub.edu \\ ${ }^{2}$ Current address: The Ecosystems Center, Marine Biological Laboratory, Woods Hole, USA.
}

\begin{abstract}
:
The sensitivity of deep-water formation to climate variability during the last $2500 \mathrm{yr}$ in the northwestern Mediterranean Sea is analysed using the grain-size parameter "UP10" (\% fraction $>10 \mu \mathrm{m}$ ) from two multicores collected north of Minorca. Proxy validation was performed by using 2012-2014 oceanographic data from two deep-water mooring-lines equipped with near-bottom sediment traps and currentmeters in the Gulf of Lion and north of Minorca. Cold and dry regional winds triggered an intense dense water formation event in winter 2013 and enhancements of bottom current speed as a result of dense shelf water cascading at the Gulf of Lion and open-sea deep convection. During this event, a distinctive particle mode and higher UP10 values are present in settling particles in sediment traps, which also appear during some periods in the grain-size distribution in sediment cores.

The chronological framework has been robustly constructed following a multi-proxy methodology. Our $2500 \mathrm{yr}$ deep-water sediment record shows that the strongest deepwater formation events occurred during relatively warm intervals, such as the Roman Period and the end of the Medieval Climate Anomaly (MCA). By contrast, during the Early Middle Ages (EMA) there was a progressive overturning reduction in the study area and weaker deep-water formation events during most of the MCA. Intense overturning events appear to be mostly associated with periods of enhanced Evaporation-Precipitation (EP) balance rather than to buoyancy loss due to winter cooling alone. Our results suggest that warm sea surface temperature during the spring months could have played an important role by increasing the EP balance and favouring buoyancy loss by increasing salinity in the upper water layers. The comparison of our data with independent oceanographic and climatic records indicates a shift in the proxy-relation before and after the EMA. Western Mediterranean Deep Water and Levantine Intermediate Water started behaving oppositely way after this period, thus depicting a Mediterranean-seesaw pattern for the last 2500yr, which deserves discussion in the frame of different atmospheric configurations.
\end{abstract}


Key words: Deep-water formation, Open-sea deep convection, Dense shelf water cascading, Western Mediterranean Deep Water, Last 2500 years 


\title{
LONG TERM TREND IN SURFACE TEMPERATURE IN THE CANARY ISLANDS FROM IN-SITU OBSERVATIONS
}

\author{
Gutiérrez-Guerra, M.Á. ${ }^{1}$, Pérez-Hernández, M.D. ${ }^{2}$ and Vélez-Belchí, P $^{3}$ \\ ${ }^{1,2}$ Unidad de Océano y Clima, Instituto de Oceanografía y Cambio Global, IOCAG, Universidad \\ de Las Palmas de Gran Canaria, ULPGC, Unidad Asociada ULPGC-CSIC, Las Palmas de Gran \\ Canarias, Spain. \\ miguel.gutierrez104@alu.ulpgc.es,mdolores.perez@ulpgc.es \\ ${ }^{3}$ Centro Oceanográfico de Canarias, Instituto Español de Oceanografía, Spain. \\ pedro.velez@ieo.es
}

\begin{abstract}
Sea Surface Temperature (SST) data from remote sensing (NOAA AVHRR) between 1999 and 2019 show a warming trend of $0.28^{\circ} \mathrm{C}$ per decade in the oceanic waters of the Canary Currents Large Marine Ecosystem (CCLME) and $-0.05^{\circ} \mathrm{C}$ per decade in some of the strongest upwelling cells in the CCLME. However, there are only a few in-situ long term observations in the CCLME to validate the observed trends. Here we use a set of insitu data provided by four buoys located between Gran Canaria and Tenerife islands from the "Puertos del Estado" network to carry out a comparison with the satellite observations. The comparisons permitted to determine the uncertainty of the observed trends in the oceanic waters of the CCLME and, based on that, estimate the uncertainty in trends of the Eastern Boundary Upwelling System obtained from SST.
\end{abstract}

Key words: Sea Surface Temperature, Upwelling, Remote Sensing

\section{References:}

Vélez-Belchí, P., González-Carballo M., Pérez-Hernández ,M.D., and Hernández-Guerra, A. (2015): Internannual, interdecadal and long-term variability. Open Ocean Temperature and salinity trends in the Canary Current large marine ecosystem (pp.299-320). Oceanographic and biological features in the Canary Current large Marine Ecosystem.Intergovenmental Oceanographic Commission-UNESCO, Technical Series 115. http://hdl.handle.net/1834/9196

Bakun, A. (1990). Global climate change and intensification of coastal ocean upwelling. Science, Vol. 247 (4939), pp. 198-201. doi:10.1126/science.247.4939.198.

Barton, E. D., Field, D. B. and Roy, C. (2013). Canary current upwelling: More or less? Progress in Oceanography, Vol. 116, pp. 167-178. doi:10.1016/j.pocean.2013.07.007. 


\title{
NATURAL CO2 SEEPS GIVE CLUES ABOUT FISH ADAPTATION TO OCEAN ACIDIFICATION
}

\author{
Petit-Marty N.*1, Nagelkerken I. ${ }^{2}$, Connell SD. ${ }^{2}$, and Schunter C. ${ }^{1}$ \\ ${ }^{1}$ SWIRE Institute of Marine Sciences. School of Biological Sciences. Kadoorie Biological \\ Sciences Building. The University of Hong Kong. Pok Fu Lam Road. Hong Kong SAR. \\ natpetit@hku.hk,schunter@hku.hk \\ ${ }^{2}$ Southern Seas Ecology Laboratories, School of Biological Sciences and The Environment \\ Institute, DX 650 418, The University of Adelaide, Adelaide, SA 5005, Australia \\ ivan.nagelkerken@adelaide.edu.au,sean.connell@adelaide.edu.au
}

Volcanic $\mathrm{CO}_{2}$ seeps at White Island (New Zealand) are natural laboratories that provide insights into the effects of ocean acidification on fishes in nature. The common triplefin, Forsterygion lapillum, is a behaviourally dominant species at these seeps with significantly greater population densities than at sites with ambient $\mathrm{CO}_{2}$ levels (1). These observations together with some other behavioural and physiological traits suggest that common triplefin have successfully adapted to live in a low $\mathrm{pH}$ environment (1). However, little is known about the mechanisms that allow life in such an environment. In this study, we contrast the levels of gene expression in gonads from triplefins collected at $\mathrm{CO}_{2}$ seeps (lower $\mathrm{pH}, \mathrm{N}=10$ ) and neighbouring controls (ambient $\mathrm{pH}, \mathrm{N}=10$ ). The body length of the collected individuals was recorded and their RNA was extracted and sequenced. RNA-seq reads were de novo assembled and a good-quality reference transcriptome for common triplefin was built using gene orthology data from genomes of related species $(\mathrm{N}=13,603$ genes). Gene expression quantification revealed that the average gene expression across the whole transcriptome is significantly higher in individuals from $\mathrm{CO}_{2}$ seeps than in neighbouring zones. Differences in average gene expression were significant for males but not for females. Fishes from the $\mathrm{CO}_{2}$ vents showed 66 up-regulated genes related with different functions, especially with transmembrane transport, metal ion binding and oxidation-reduction processes. These observations suggest that higher levels of gene expression in males from $\mathrm{CO}_{2}$ seeps are an adaptive response for maintenance of cellular homeostasis and energy production.

Key words: ocean acidification, adaptation, RNA-seq, gene expression, transcriptome

\section{References:}

Nagelkerken, I., Goldenberg, S. U., Ferreira, C. M., Russell, B. D., \& Connell, S. D. (2017). Species interactions drive fish biodiversity loss in a high-CO2 world. Current Biology, 27(14), 2177-2184. 


\title{
IDENTIFYING HOMOGENOUS COASTAL UNITS IN TERMS OF VULNERABILITY AND ADAPTATION CAPACITY TO CLIMATE CHANGE
}

\author{
R. Romero-Martín ${ }^{*}{ }^{1}$, H.I. Valdemoro ${ }^{1}$ and J.A. Jiménez ${ }^{1}$ \\ ${ }^{1}$ Laboratori d'Enginyeria Marítima, Universitat Politécnica de Catalunya-BarcelonaTech, \\ Barcelona, SPAIN. \\ rut.romero@upc.edu,herminia.valdemoro@upc.edu,jose.jimenez@upc.edu
}

\begin{abstract}
There are numerous evidences of the deleterious consequences of enhanced pressures on coastal areas worldwide due to human activities and climate change (Wong et al., 2014). One of the most important requirements for a sound and sustainable management of coastal areas is the assessment of their vulnerability to existing hazards and their natural capacity of adaptation. This will help designing coastal plans fully taking into account territorial differences (and similarities) in terms of vulnerability, natural resilience, resources and values, and natural adaptive capacity.
\end{abstract}

Here we present a methodology for identifying homogeneous coastal units to be used in the development of coastal adaptation plans to climate change. The method has been derived for typical Mediterranean conditions and has been applied to the entire coastline of Catalonia and Valencia regions. It uses coastal state indicators to characterize coastal vulnerability to climate hazards (current and associated to climate change), resilience, values exposed and (natural) adaptation capacity. Six indicators are applied to compose a hazard index. These are intrinsic geomorphic susceptibility, susceptibility to long-term sea-level rise (SLR)-induced erosion and inundation, medium-term background coastline stability, storm-induced erodibility and SLR magnitude. Accommodation space to assess adaptation capacity is valued against a benchmark related to expected long-term needs. Values at exposure are indicated valuing socio-economic features along the coast similarly than Viavattene et al. (2018). Finally, all these values are integrated in an overall index that which is spatially integrated at a minimum management scale, the municipality. The final work will present the results obtained for the study area.

Key words: Coastal vulnerability, Sea-level rise, Coastal management, Adaptation

Acknowledgments: This work has been done in the framework of the M-CostAdapt (CTM2017-83655-C2-1-R) research project, funded by the Spanish Ministry of Economy and Competitiveness (MINECO). 


\section{References:}

Viavattene, C., Jiménez, J.A., Ferreira, O., Priest, S., Owen, D. and McCall, R. (2018). Selecting coastal hotspots to storm impacts at the regional scale: a Coastal Risk Assessment Framework. Coastal Engineering, 134, 33-47.

Wong, P.P., Losada, I.J., Gattuso, J.-P., Hinkel, J., Khattabi, A., McInnes, K.L., Saito, Y. and Sallenger, A. (2014). Coastal systems and low-lying areas. In C.B. Field et al. (eds.): Climate Change 2014: Impacts, Adaptation, and Vulnerability. Part A: Global and Sectoral Aspects. Cambridge University Press, Cambridge, United Kingdom and New York, NY, USA, p. 361-409. 
VII International Symposium on Marine Sciences

ISMS 2020

Barcelona (Spain), $1^{\text {st }}-3^{\text {rd }}$ July 2020

\title{
OCEAN WARMING AND ACIDIFICATION IMPACTS ON ENERGY BUDGET AND OXIDATIVE RESPONSES OF ZEBRA SEABREAM (DIPLODUS CERVINUS)
}

\author{
Sandra Martins ${ }^{1}$, Mariana Carmona ${ }^{2}$, Ana Luísa Mauvault ${ }^{3}$, Vera Barbosa ${ }^{4}$, \\ Marta Santos $^{5}$, Pedro Pousão-Ferreira ${ }^{6}$, Luísa M.P. Valente ${ }^{7}$, António Marques ${ }^{8}$, \\ Rui Rosa9, Mário Diniz ${ }^{10}$ and Patrícia Anacleto*11 \\ 1, 3,9,11 Marine and Environmental Sciences Centre (MARE) - Guia Marine Laboratory, Faculty of \\ Sciences, University of Lisbon (FCUL), Cascais, PORTUGAL \\ srmelovm@gmail.com, aluisa@ipma.pt,rarosa@fc.ul.pt,panacleto@ipma.pt \\ 3, 4, 5, 6, 8,11 Division of Aquaculture and Upgrading (DivAV), Portuguese Institute for the Sea and \\ Atmosphere (IPMA, I.P.), Lisboa, PORTUGAL \\ aluisa@ipma.pt,vera.barbosa@ipma.pt,marta.santos@ipma.pt,pedro.pousao@ipma.pt, \\ amarques@ipma.pt,panacleto@ipma.pt \\ ${ }^{1}$ Comparative Endocrinology and Integrative Biology, Center of Marine Sciences (CCMAR), \\ University of Algarve, Faro, PORTUGAL \\ srmelovm@gmail.com \\ 2, 4, 10 UCIBIO, Department of Chemistry, Faculdade de Ciências e Tecnologia, Universidade \\ NOVA de Lisboa, Caparica, PORTUGAL \\ m.carmona@campus.fct.unl.pt,vera.barbosa@ipma.pt,mesd@fct.unl.pt \\ 3, 4, 7, 8,11 Interdisciplinary Centre of Marine and Environmental Research (CIIMAR), University of \\ Porto, Porto, PORTUGAL \\ aluisa@ipma.pt,vera.barbosa@ipma.pt,lvalente@icbas.up.pt,amarques@ipma.pt, \\ panacleto@ipma.pt \\ ${ }^{7}$ Instituto de Ciências Biomédicas de Abel Salazar (ICBAS), University of Porto, Porto, \\ PORTUGAL \\ lvalente@icbas.up.pt
}

\begin{abstract}
:
As direct result of anthropogenic greenhouse emissions, the global ocean has sequestered about $30 \%$ of the released carbon dioxide and absorbed more than $90 \%$ of the heat produced $[1,2,3,4]$. According to the 2019 IPCC report [4], it is estimated a seawater $\mathrm{pH}$ decrease between 0.065 and 0.317 units and a seawater surface temperature increase between 0.20 and $3.51^{\circ} \mathrm{C}$ by the end of the century.

Ocean warming and acidification (OWA) deeply affects marine organisms' physiological responses in ways that often can generate reactive oxygen species (ROS) and oxidative stress, thus, compromising their energy budget [5,6]. However, fish bioenergetics and oxidative responses under different climate change scenarios remain unclear. Within this context, the present study aimed to investigate the effects of seawater warming $(\mathrm{OW})$ and acidification (OA) on the energy budget (growth, excretion, metabolism and food consumption), as well as antioxidant responses (superoxide dismutase - SOD, catalase CAT and glutathione peroxidase - GPx activities) and ubiquitin production in muscle and
\end{abstract}


liver of juvenile zebra seabream.

The energy spent in animal growth dominated fish energy under OWA. Moreover, while ammonium excretion rate decreased, fat and protein whole body contents and viscerosomatic index increased under $\mathrm{OA}$. On the other hand, under $\mathrm{OW}$, increased metabolic rates were registered. The exposure to OWA increased SOD and decreased CAT and ubiquitins activities in the muscle. Contrarily, the combined environmental stressors decreased SOD and GPx activities in the liver tissue. OW was responsible for CAT increment and for the loss of ubiquitins activities in the liver. Hence, stress conditions induced by OWA are expected to greatly affect the energy budget and compromisse oxidative responses of marine fish, with potential cascading effects at community levels.

Alongside, such experimental studies are extremely relevant to enable the development of mitigation/adaptation measures in ocean uses (e.g. aquaculture sector) under a changing climate.

Key words: Energy Budget, Ocean Acidification, Ocean Warming, Oxidative Stress, Teleost Fish

\section{Acknowledgments:}

This study was supported by the project FISHBUDGET - Effects of climate change on marine fish energy budgets (PTDC/BIA-BMA/28630/2017) from the Portuguese Foundation for Science and Technology (FCT). This study benefited from the strategic program of MARE, financed by FCT (MARE-UID/MAR/04292/2019) and from the strategic program of UCIBIO, financed by FCT (UIDB/04378/2020). FCT supported the contracts of PA, AM e RR in the framework of the CEECIND 2017 (CEECIND/01739/2017), IF2014 (IF/00253/2014) and IF2013 programs (IF/01373/2013), respectively. The project FISHBUDGET also supported the research contract of ALM. The authors also thank the Sparos Lda company for providing the fish feed, and the team from EPPO aquaculture pilot station (Olhão) for providing the juvenile fish for trials.

\section{References:}

[1] Field, C.B., Barros, V.R., Dokken, D.J., Mach, K.J., Mastrandrea, M.D., Bilir, T.E., Chatterjee, M., Ebi, K.L., Estrada, Y.O., Genova, R.C., Girma, B., Kissel, E.S., Levy, A.N., MacCracken, S., Mastrandrea, P.R., White, L.L. (2014). Climate change 2014 impacts, adaptation and vulnerability: Part A: Global and sectoral aspects: Working group II contribution to the fifth assessment report of the intergovernmental panel on climate change.

[2] Barange, M., Bahri, T., Beveridge, M.C.M., Cochrane, K.L., Funge-Smith, S. \& Poulain, F. (2018). Impacts of climate change on fisheries and aquaculture: synthesis of current knowledge, adaptation and mitigation options in FAO Fisheries and Aquaculture Technical Paper 627, ISBN 978-92-5-130607-9.

[3] Bindoff, N.L., P.A. Stott, K.M. AchutaRao, M.R. Allen, N. Gillett, D. Gutzler, K. Hansingo, G. Hegerl, Y. Hu, S. Jain, I.I. Mokhov, J. Overland, J. Perlwitz, R. Sebbari and X. Zhang (2013). Detection and Attribution of Climate Change: from Global to Regional. In: Climate Change 2013: The Physical Science Basis. Contribution of Working Group I to the Fifth Assessment Report of the Intergovernmental Panel on Climate Change [Stocker, T.F., D. Qin, G.-K. Plattner, M. Tignor, S.K. Allen, J. Boschung, A. Nauels, Y. Xia, V. Bex and P.M. Midgley (eds.)]. Cambridge University Press, Cambridge, United Kingdom and New York, NY, USA, 867-952.

[4] IPCC (2019). Abram, N., J.-P. Gattuso, A. Prakash, L. Cheng, M.P. Chidichimo, S. Crate, H. Enomoto, M. Garschagen, N. Gruber, S. Harper, E. Holland, R.M. Kudela, J. Rice, K. Steffen, and K. von Schuckmann, 2019: Framing and Context of the Report. In: IPCC Special Report on the Ocean and Cryosphere in a Changing Climate [H.-O. Pörtner, D.C. Roberts, V. Masson-Delmotte, P. Zhai, M. Tignor, E. Poloczanska, K. 
Mintenbeck, A. Alegría, M. Nicolai, A. Okem, J. Petzold, B. Rama, N.M. Weyer (eds.)]. In press.

[5] Jobling, M. (1994). Fish bioenergetics. Chapman \& Hall, London. 309p.

[6] Yurista, P.M. (1999). Temperature-dependent energy budget of an Artic Cladoceran, Daphnia middendorffiana. Freshwater Biology 42: 21-34. 


\title{
COASTAL HAZARD EVOLUTION UNDER DIFFERENT CLIMATE CHANGE SCENARIOS IN RIA FORMOSA, PORTUGAL
}

\author{
Thet Oo Mon ${ }^{1}$, Theocharis Plomaritis ${ }^{2}$, Óscar Ferreira ${ }^{3}$, Lorenzo Mentaschi ${ }^{4}$ and \\ Michalis Vousdoukas ${ }^{5}$ \\ 1, 2 University of Cádiz, Cádiz, SPAIN. \\ thetoomon.mon@gmail.com,haris.plomaritis@uca.es \\ ${ }^{3}$ University of Algarve, CIMA/FCT, Faro, PORTUGAL. \\ oferreir@ualg.pt \\ 4,5 European Commission, Joint Research Centre, Ispra, Italy \\ lorenzo.mentaschi@ec.europa.eu,michalis.vousdoukas@jrc.ec.europa.eu
}

\begin{abstract}
Among the various effects of climate change, sea level rise and the increasing intensity of floods will cause adverse economic loss in low-lying coastal areas. The risks due to erosion and flooding hazards from these effects will likely increase in Ria Formosa, an economically and ecologically important coastal lagoon in the southern coast of Portugal. The identification of critical zones for coastal hazards considering present and future scenarios will provide a valuable input for better decision-making for management and planning of these coastal areas. This study provides an initial assessment and reliable quick overview on the evolution of hazard levels considering different climate change scenarios. We identify possible future hotspot areas ( $1 \mathrm{~km}$ resolution) related to erosion and flooding hazards at a regional scale $(60 \mathrm{~km})$ in Ria Formosa under climate change. Wave data from a 6-model ensemble for RCP4.5 and RCP8.5 pathways (2010-2099) were used together with the coastal risk assessment framework, CRAF (Viavattene, C. et al. 2018) to predict the potential hazard levels of flooding and erosion resulting from low-frequency, high-impact, hydrometeorological events (Plomaritis et al., 2018). The results provide the temporal and spatial variability of the significant hot-spot areas in Ria Formosa and thus highlight the priority areas to implement relevant risk management measures and/or early warning systems. This study provides an overview on the relative temporal and regional change of flooding and erosion hazards under multiple future scenarios, applicable to other sandy coastal areas.
\end{abstract}

Key words: Coastal Hazards, Climate Change, Storms

Acknowledgments: The authors would like to express sincere gratitude to the Erasmus ${ }^{\text {programme }}$ and the European Union, professors and researchers from the partner universities (University of Bologna, University of Algarve, University of Cadiz) of the Water and Coastal Management (WACOMA). 


\section{References:}

Plomaritis, T. A., Ferreira, Ó. and Costas, S. (2018) 'Regional assessment of storm related overwash and breaching hazards on coastal barriers', Coastal Engineering, 134(February 2017), pp. 124-133. doi: 10.1016/j.coastaleng.2017.09.003.

Viavattene, C. et al. (2018) 'Selecting coastal hotspots to storm impacts at the regional scale: a Coastal Risk Assessment Framework', Coastal Engineering, 134(January 2017), pp. 33-47. doi:

10.1016/j.coastaleng.2017.09.002. 


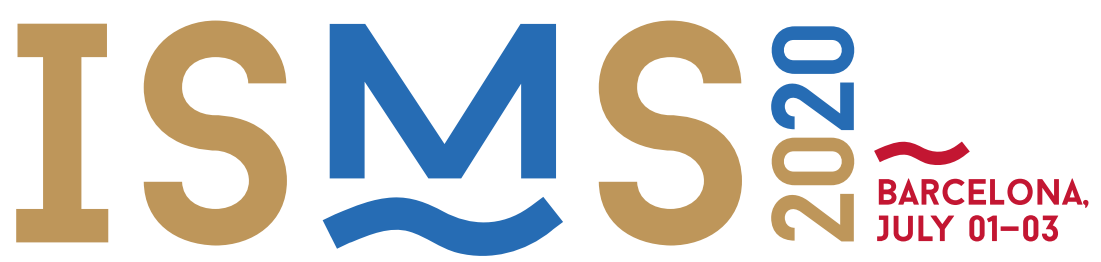

VII INTERNATIONAL SYMPOSIUM ON MARINE SCIENCES BULY 01-03

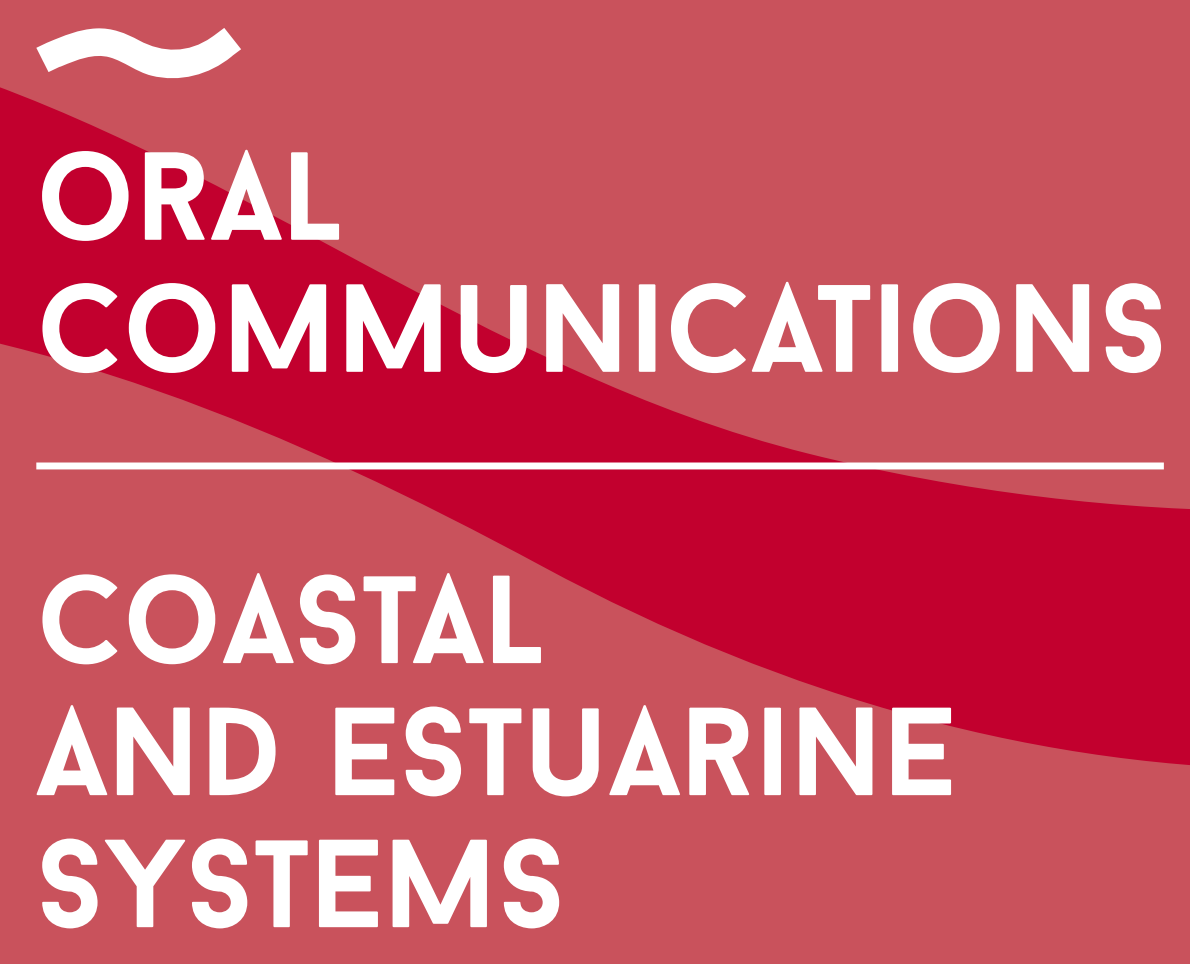




\title{
HISTORICAL BEACH EVOLUTION AND CURRENT STATUS OF THE MARESME LITTORAL CELL
}

\author{
N. Carrión ${ }^{1}$ and A. Calafat ${ }^{1}$ \\ ${ }^{1,}$ Department de Dinàmica de la Terra i de l'Oceà, Universitat de Barcelona, Barcelona, SPAIN. \\ nil.carrion@gmail.com, antonicalafat@ub.edu
}

\begin{abstract}
Inman and Chamberlain (1960) first defined the concept of "littoral cell" as "a coastal compartment that contains a complete cycle of sedimentation (supply, transport and sinks)". The size of a littoral cell can vary from one to hundreds of kilometres. Within a littoral cell, the sediment budget is balanced, providing the framework for the quantitative analysis of erosion and accumulation. The concept of a coastal cell is widely used in coastal management.
\end{abstract}

This study focuses on the $49 \mathrm{~km}$ long Maresme coast north of Great Barcelona. About $30 \mathrm{Km}$ of the Maresme shoreline consist of medium and coarse-grained quartiziferous sandy beaches with a steep slope. Until the 1940s the Maresme coastline was made of a succession of balanced beaches, which were mainly fed by Tordera River to the north. The Maresme coastal cell has been recognized by different authors, from Serra et al. (1989) to CEDEX (2014).

Here we show how the Maresme beaches have evolved before and after the construction of hard coastal protection structures from 1946 to 2018. After sediment sampling at different locations, we have tried also to establish the relationship in bettween the interruption of the littoral drift by those structures, beach width evolution and sediment grain size. This allowed us stating the current status of the Maresme coastal cell, which comes to be segmented into two cells bounded by the harbour of Mataró.

Key words: Littoral cell, Littoral drift, Coastal protection, Maresme coast

\section{References:}

CEDEX (2014). Estudios de dinámica litoral, defensa y propuestas de mejora en las playas con problemas erosivos, considerando los efectos del cambio climático: Estrategia de actuación en el Maresme. Dirección General de Sostenibilidad de la Costa y el Mar.

Inman, D.L. and Chamberlain, T.K. (1960). Littoral sand budget along the southern California coast. Report of the 21st International Geological Congress, Copenhagen, Denmark, Abstr. Vol., p. 245-246.

Serra, J., Calafat, A. and Canals, M. (1989). Dinámica sedimentaria de una costa subalimentada. Respuesta a la regeneración artificial. XII Cong. Esp. Sedimentología, Bilbao, Vol. Simp. y Conf., p. 239-240. 


\title{
RECOVERY OF THE COAST OF HUELVA AFTER STORM EMMA
}

\author{
M. F. Macià ${ }^{1}$, J. Montes ${ }^{1}$ and J. Benavente ${ }^{1}$ \\ ${ }^{1}$ Earth Science Department, Cádiz University, Cádiz, SPAIN. \\ maria.fernandezmacia@alum.uca.es,juan.montes@uca.es \\ javier.benavente@uca.es
}

\begin{abstract}
Sea storms are one of the main causes of natural changes, especially on sandy beaches. This study focuses on beach recovery in three locations of the coast of Huelva (Gulf of Cadiz) after Emma major sea storm from $27^{\text {th }}$ of February to $4^{\text {th }}$ of March 2018. The studied beaches area Doñana (near the Guadalquivir River mouth), Bota (near Piedras River mouth) and Ayamonte (near Guadiana River mouth). Topographical surveys have been carried out with RTK-coiled GPS devices. The study period covers from April 2018 to September 2019. Emma involved wave heights up to $6 \mathrm{~m}$, strong SW winds and completely eroded and modified the former beach profiles. One year after the storm, beach profiles showed clear signs of recovery, although each of the three studied beaches presented different volumetric recovery. Reflective or intermediate beaches like Doñana showed a larger recovery, from both the volumetric and morphodynamic view. After the storm, Doñana beach recovered towards reflective values, especially along it is westernmost part. More dissipative beaches, such as Bota and Ayamonte, showed less ability to cope with storm-induced changes. Despite this, these two beaches also recovered, with the profile closet to the Guadiana River changing from ultra-dissipative to dissipative.
\end{abstract}

Key words: Beach erosion, volumetric recovery, sea storm, Huelva.

Acknowledgments: This research was funded by the European Interreg $\mathrm{V}$ España Portugal (POCTEP) 0139_VENUS_5_E research project and is a contribution of research group RNM-328 of the Andalusian Research Plan (PAI). J. Montes was supported by a FPI contract (BES-2015-073218) of the Spanish Ministry of Economy and Competitiveness. 


\title{
PALEOENVIRONMENTAL EVIDENCE OF "ALBUFERA DE VALENCIA" COASTAL BARRIER STABILISATION FROM 8,500 YR BP TO PRESENT
}

\author{
M. López-Belzunce* ${ }^{1}$ and A.M. Blázquez ${ }^{1}$ \\ ${ }^{1}$ Environmental and Marine Sciences Research Institute (IMEDMAR), Catholic University of \\ Valencia, C/Guillem de Castro 94, 46003 Valencia, Spain \\ malobel@ucv.mail.es,ana.blazquez@ucv.es
}

\begin{abstract}
Identifying the mechanisms that play the main role in the stabilization of coastal environments is essential to obtain information for improving predictions on the range of sea level changes in the short and medium term. Coastal barriers are highly sensitive to current climate change (Fletcher and Zielhofer, 2013) and to increasing anthropogenic impacts in coastal areas (Bellin et al., 2013).
\end{abstract}

Here we present the results of the study of a $14 \mathrm{~m}$ long sediment core $\left(39^{\circ} 23^{\prime} 29.16^{\prime \prime} \mathrm{N}\right.$, $\left.0^{\circ} 20^{\prime} 43.80^{\prime \prime} \mathrm{W}\right)$ from Albufera de Valencia coastal lagoon. The analyses performed included determination of foraminiferal assemblages, organic matter and calcium carbonate contents, and grain size. $\mathrm{C}^{14}$ dating of the core bottom yielded an age of $8,418 \pm 77$ cal yr BP.

The core record showed four different environments that developed in eight phases.

Sandy alluvial sediments without foraminifera formed the core bottom. Then a brackish environment developed as indicated by Ammonia tepida (Cushman), Criboelphidium excavatum (Terquem), Haynesina germanica (Ehrenberg), and brackish water bivalves and gastropods in sediments with high clay and silt contents. The third environment corresponds to a brackish lagoon with connected to the open sea, as indicated by the presence of Rosalina mediterranensis d'Orbigny, Adelosina duthiersi Schlumberger, Ammonia beccarii (Linné), bivalves and Posidonia oceanica Delile in sediments with higher contents calcium carbonate and sand (quartz) than the previous unit. Foraminifera diversity values were also higher. Finally, the topmost silty and clayey unit is interpreted as a freshwater marsh as it shows charophytes, vegetation remnants and rhizotubules, and lacks foraminifera.

The above-described paleoenvironmental evolution is interpreted as a response to global climate changes. The shift from an alluvial setting to a brackish lagoon likely relates to the late Holocene sea level rise ending at the Holocene Climate Optimum, when the highest sea level took place. The persistence of the brackish lagoon, with no marine connection, likely is synchronous with dry conditions in the area (Booth et al., 2005) at the time of Bond event 3 (i.e. $4.2 \mathrm{ka}$ ) in the North Atlantic region (Bond et al., 2001). Finally, of the 
arrival of large amounts of sediment triggered the accretion of the barrier also enhancing coastal progradation till nowadays (Carmona et al., 2016).

Key words: Coastal barrier, Foraminifera, Holocene, Western Mediterranean Sea

Acknowledgments: This study was supported by UCV/2017-153-001 and UCV/2018153- 002 grants from Catholic University of Valencia.

\section{References:}

Bellin, N., Vanacker, V. and De Baets, S. (2013). Anthropogenic and climatic impact on Holocene sediment dynamicin SE Spain: a review. Quaternary International, 308-309, 112-129.

Bond, G., Kromer, B., Beer, J., Muscheler, R., Evans, M.E., Showers, W., Hoffman, S., Lotti-Bond, R., Hajdas, I. and Bonani, G. (2001). Persistent solar influence on North Atlantic climate during the Holocene. Science, 249, 2130-2136.

Booth R.K, Jackson S.T. and Forman S.L. (2005). A severe centennial scale drought in midcontinental North America 4200 years ago and apparent global linkages. The Holocene, 15, 321-328.

Carmona, P., Ruiz-Pérez, J.M., Blázquez, A.M., López-Belzunce, M., Riera, S. and Orengo, H. (2016). Environmental evolution and mid-late Holocene climate events in the Valencia lagoon (Mediterranean coast of Spain). Holocene, 26:1750-1765.

Fletcher, W.J. and Zielhofer, C. (2013). Fragility of Western Mediterranean landscapes during Holocene rapid climate changes. Catena, 103, 16-29. 


\title{
PATTERNS OF VARIABILITY OF SATELLITE DERIVED OPTICAL PARAMETERS IN THE MEGHNA ESTUARY AND THEIR RESPONSE TO CLIMATIC INDICES
}

\author{
Masuma Chowdhury*1, Irene Laiz Alonso ${ }^{1}$ and Isabel Caballero de Frutos ${ }^{2}$ \\ ${ }^{1}$ Departamento de Física Aplicada, Facultad de Ciencias del Mar y Ambientales (CASEM), \\ Campus Universitario Río San Pedro, S/N 11510 Puerto Real (Cádiz), Spain. \\ masuma.chowdhury@alum.uca.es,irene.laiz@uca.es \\ ${ }^{2}$ Department of Ecology and Coastal Management, Instituto de Ciencias Marinas de Andalucía \\ (ICMAN-CSIC), Campus Universitario Río San Pedro, S/N 11510 Puerto Real (Cádiz), Spain \\ isabel.caballero@icman.csic.es
}

\begin{abstract}
Meghna estuary, located in the northern Bay of Bengal (BoB), is a complex and dynamic estuarine system for its irregular shape, wide seasonal variation and the changing role of tides (Uddin et al., 2015; Islam et al., 2002). Every year, a major portion of the flow with high amount of sediments from the Ganges-Brahmaputra-Meghna river system is transferred through this estuary to the $\mathrm{BoB}$ and influences the physical and biological processes in the adjacent area. This study aimed at (1) evaluating patterns in seasonal and interannual variability of chlorophyll-a, total suspended matter (TSM), sea surface temperature (SST) and underlying environmental determinants within Meghna estuary and its adjacent coastal area during a 9-year period (2003-2011), and (2) assessing whether climatic indices, i.e., Indian-Ocean-Dipole (IOD) and El-Niño/Southern-Oscillation (ENSO) affect the region in different ways. An empirical orthogonal Function (EOF) analysis of satellite-retrieved water optical parameters, acquired from GlobColour project (http://globcolour.info/) and Ocean Color Project (https://oceancolor.gsfc.nasa.gov), 4-km, monthly resolution, was used to find out the dominant modes in the study area. A set of local physical variables and large-scale climatic indices were used as environmental variables. Stepwise linear regression was also applied to unravel the relationship among the studied parameters. Before deseasonalising the variables, only the first EOFs mode was found to be relevant, representing $25.55 \%, 15 \%$ and $89.43 \%$ of chlorophyll-a, TSM and SST variance respectively, and corresponding to the annual signal. Chlorophyll-a concentration was found higher in winter than in summer which reveals the influence of upwelling phenomena. Besides, chlorophyll-a concentration is highly correlated with TSM concentrations. The mean spatial distribution of the studied variables showed clear latitudinal patterns in case of chlorophyll-a and TSM, with higher values around the northern coast and a gradual offshore decreasing gradient. The SST map showed the same spatial pattern but with lower temperature values around the northern coastal fringe and higher values offshore.
\end{abstract}


Key words: Ocean remote sensing, EOF analysis, IOD, ENSO, Meghna estuary.

Acknowledgments: This work was performed for partial fulfillment of requirements for M.Sc. in Water and Coastal Management (WACOMA) under Erasmus Mundus Joint Master Degree (EMJMD) Scholarship program. We are thankful to ESA and NASA for freely distributing the satellite data used in this study.

\section{References:}

Islam, M. R., Begum, S. F., Yamaguchi, Y., \& Ogawa, K. (2002). Distribution of suspended sediment in the coastal sea off the Ganges-Brahmaputra River mouth: Observation from TM data. Journal of Marine System, 32(4), 307-321.

Uddin, M., Alam, Dr. Md. J., Khan, Z., Hasan, G. M. J., \& Alam, R. (2015). Numerical Simulation: HydroMorphology of Meghna Estuary. The International Journal of Ocean and Climate Systems, 6, 173184. 


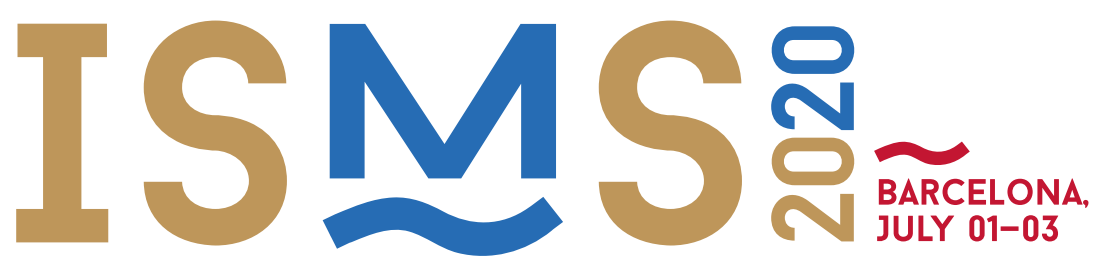

VII INTERNATIONAL SYMPOSIUM ON MARINE SCIENCES BARCELONA
JULY 01-03

ORAL COMMUNICATIONS

\section{LIVING} RESOURCES 


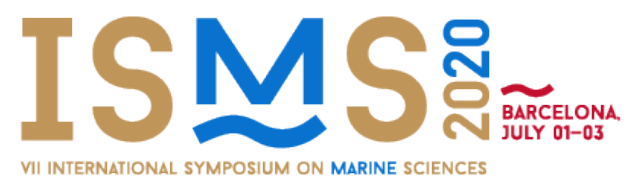

VII International Symposium on Marine Sciences

ISMS 2020

Barcelona (Spain), $1^{\text {st }}-3^{\text {rd }}$ July 2020

\section{SUSTAINABLE MANAGEMENT OF ARTISANAL SWORD RAZOR CLAM FISHERIES IN GALICIA (NW SPAIN): THE IMPORTANCE OF MATCHING WITH THE REPRODUCTIVE CYCLE}

\author{
A. Tubío* ${ }^{1,2}$, T. Ballesteros ${ }^{1,2}$, A. Hernández ${ }^{1,2}$, R. Rodríguez ${ }^{1}$, D. Costas ${ }^{1}$, F. \\ Febrero $^{3}$, G. Macho $^{2}$ and E. Vázquez ${ }^{1,2}$ \\ ${ }^{1}$ Toralla Marine Science Station (ECIMAT), Marine Research Center of the University of Vigo \\ (CIM-UVigo), Illa de Toralla, 36331 Vigo, Pontevedra, SPAIN. \\ atubio@uvigo.es,tballesteros@uvigo.es,alba.hernandez@uvigo.es,rrodriguez@uvigo.es, \\ dcostas@uvigo.es,eotero@uvigo.es \\ ${ }^{2}$ Department of Ecology and Animal Biology, Faculty of Experimental Sciences, University of \\ Vigo, 36310 Vigo, Pontevedra, SPAIN. \\ gmacho@uvigo.es \\ ${ }^{6}$ Marine Research Center, Consellería do Mar, Xunta de Galicia, 36620 Vilanova de Arousa, \\ Pontevedra, SPAIN. \\ fernando.febrero.mayor@xunta.es
}

\begin{abstract}
Spatially, razor clam (Ensis magnus) stocks are highly structured forming metapopulations with large spatial variability even within the same fishing ground, which influences population dynamics (e.g. reproduction). Fishers in Galicia point out two problems regarding the management of sword razor clam fisheries: 1) the two-month reproductive closure causes local market shortages and leads to the import of foreign razor clams, and 2) excessive discards of broken razor clams during some months as a result of foot breakage when harvesting fully mature individuals. Both problems are connected and remain unsolved.
\end{abstract}

Here we describe the spatial and temporal variability of the reproductive cycle of $E$. magnus in Ría de Vigo and its relation with temperature, salinity and chlorophyll $a$ in order to provide information to adapt the management of the fishery to the biological cycle of this species. From January 2018 to July 2019, the reproductive cycle of E. magnus was monitored fortnightly in five exploited beds in Ría de Vigo using histological methods.

Results show a reproductive cycle characterized by a sexual rest stage during summer and early autumn (temperature is higher and the water is rich in nutrients, and E. magnus accumulates reserves), a start of gametogenesis in autumn (temperature and nutrients decrease, with gametogenesis starting at the expense of stored reserves) and a period of successive spawns interspersed with gonadal restoration during winter and spring, as previously noticed by Darriba (2001), Darriba et al. (2005) and Hernández-Otero et al. (2014) in Ría de Vigo and in Ría de Pontevedra. However, our results do not show a clear spatial pattern. 
We point to the convenience of adapting the rotational harvesting plan and the closure period to the variability found in the gametogenic stage of the razor clams within the ria. Easy and cheap data collection programs should be implemented in the fishery under an adaptive system allowing quick decisions to be collectively agreed by the stakeholders, also taking into account the spatial and temporal variability of the reproductive cycle of $E$. magnus.

Key words: Sword razor clam, Ensis magnus, Reproductive cycle, Fisheries management, Galicia

Acknowledgments: To all personnel of the Toralla Marine Science Station (ECIMAT), to the fisher's guild of Vigo and Cangas, and to the Galician cooperative society Cíes Artesanais SL. This study was conducted under the project "Study of the spatial variability of the reproductive cycle of the sword razor clam (Ensis magnus) in the Ría de Vigo and its application to fisheries management", financially supported by the Consellería do Mar, Xunta de Galicia.

\section{References:}

Darriba, S. (2001). Biología de la navaja (Ensis arcuatus Jeffreys, 1865) de la Ría de Vigo (N.O. de España): Crecimiento y reproducción. Tesis doctoral, Universidad de Vigo, 283 p.

Darriba, S., San Juan, F. and Guerra, A. (2005). Gametogenic cycle of Ensis siliqua (Linnaeus, 1758) in the Ría de Corcubión, Northwestern Spain. Journal of Molluscan Studies 71, 47-51.

Hernández-Otero, A., Martínez-Castro, C., Macho, G. and Vázquez, E. (2014). The reproductive cycle of the sword razor clam Ensis magnus in the Ría de Pontevedra (NW Spain): spatial variability and its relation with environmental conditions. Journal of Sea Research 91, 45-57. 


\title{
LAGRANGIAN DISPERSION AND SPATIAL DISTRIBUTION OF EARLY STAGES OF ANCHOVY (Engraulis encrasicolus) IN THE GULF OF CADIZ IN 2016
}

\section{Andrea Casaucao $^{1 *}$, Enrique González-Ortegón ${ }^{2}$, María P. Jiménez ${ }^{3}$ and Irene Laiz $^{1}$}

${ }^{1,}$ Department of Applied Physics, Univ. of Cadiz, Campus Rio San Pedro, Cadiz, Spain. andrea.casaucaoaguilar@alum.uca.es,irene.laiz@uca.es

${ }^{2}$ Instituto de Ciencias Marinas de Andalucía (CSIC). Polígono Río San Pedro s/n,

Cádiz, Spain

quique.gonzalez@icman.csic.es

${ }^{3}$ Instituto Español de Oceanografía, Centro Oceanográfico de Cádiz, Puerto Pesquero, Muelle de Levante s/n, 11006 Cádiz, Spain

paz.jimenez@ieo.es

\begin{abstract}
The use of Lagrangian models to simulate the movement of Engraulis encrasicolus larvae and eggs in the gulf of Cadiz (GoC) are key tools to know the larval destination and to characterize the spawning areas. The degree of connectivity-retention within the different areas of the Southwest Iberian Peninsula was evaluated by implementing a Lagrangian transport model for the month of August 2016. The Lagrangian model was offline coupled to the 3D daily average velocity fields obtained with the Regional Ocean Modeling System. The particles release locations corresponded to the sampling points of the ECOCADIZ 2016 campaign and the number of particles released was proportional to the eggs densities found in that campaign. The study area of the $\mathrm{GoC}$ was divided into 4 different areas in order to determine the dispersion patterns and the population connectivity of this species and evaluate the success of the larval distribution. A multivariate analysis shows that chlorophyll is the environmental variable that best characterized the spawning areas. In addition, most of the simulated organisms arriving to the western Portuguese coast and, to a lesser extent, to the Atlantic oligotrophic waters. That is, the increase in connectivity between the subdivision 9a South and West components is due to an intense countercurrent that could explain why a year later there was a gain of anchovy on the western Portuguese coast and a loss in the gulf of Cadiz.
\end{abstract}

Key words: Engraulis encrasicolus, anchovy, gulf of Cádiz, Lagrangian model, ROMS.

Acknowledgments: The authors would like to thank the staff involved in the ECOCADIZ 2016 Survey (IEO), and University of Cádiz for supporting this initiative. 


\title{
CAN SHELLFISH AFFECT THE GROWTH OF Solen marginatus (PULTENEY, 1799)?
}

\author{
Caderno, A. *1 ${ }^{1}$, Hortas, F. ${ }^{2}$, Rodríguez-García, C. ${ }^{1,}$ and Cabrera-Castro, R. ${ }^{2}$ \\ ${ }^{1}$ Department of Biology. Faculty of Marine and Environmental Sciences. Cadiz University. \\ SPAIN. \\ anyellc9402@gmail.com, carlos.rodriguezgarcia@alum.uca.es \\ ${ }^{2}$ University Institute of Marine Research (INMAR). Campus of International Excellence of the Sea \\ (CEIMAR). Avda. República Saharaui, s/n, 11510 Puerto Real, Cádiz, SPAIN. \\ francisco.hortas@uca.es, reme.cabrera@uca.es
}

\begin{abstract}
Various extractive activities take place in the Bay of Cadiz (Southwest of Cadiz). One of them is shellfishing, which is characterized by catching different species of benthic invertebrates including Solen marginatus. This species is highly appreciated gastronomically, indicating their great demand and commercial interest in the area. The objective of this work was to study the growth of this species from samples obtained from the illegal sale by shellfish. The starting hypothesis were: (1) that the average capture sizes for this species are lower than those established by the legislation in force in Andalusia, (2) the each growth ring corresponds approximately with one month of life (moon cycle). The samples were obtained monthly between January and November 2019 (898 specimens). Biometric analyzes were performed and obtained the dry weight (DW) and the ash-free dry weight (AFDW). The counting of marks or rings of growth was made taking a representative sample of each month for each age class and adjusted according to the growth model of Von Bertalanffy. In addition, the observation and monitoring of shellfishers was carried out in the different areas where this activity is carried out. Individuals with sizes less than those established by the current legislation were found $(75 \mathrm{~mm})$. The average length obtained was $72.63 \mathrm{~mm}$ and this species showed a negative allometric growth. The most frequent rings numbers observed were 15 and 14, which corresponded with 15 and 14 months of age respectively. The results of the Von Bertalanffy growth model were: $L_{\infty}=106.81, k=0.11$ y $t_{\circ}=1.62$. In the Bay of Cádiz there is a high stealth activity with $S$. marginatus, which is negatively affecting its populations. This study will provide a better understanding that will serve to manage their populations in the medium and long term adequately.
\end{abstract}

Key words: Bay of Cadiz, Bivalves, Minimum sizes, Shellfish, Solen marginatus.

Acknowledgments: To thank the different researchers of the Marine Research University Institute (INMAR) and the University of Cádiz (UCA) who collaborated with the work. Also a special thanks to the students of the UCA: Raúl, Alberto, Jaime, Jessica and Lucía for their help in the process of sampling and biometric analysis. 


\section{References:}

da Costa, F. and Martínez-Patiño, D. (2009). Culture potential of the razor clam Solen marginatus (Pennánt, 1777). Aquaculture, 288, 57-64.

Fernández-Tajes, J., González-Tizón, A.M., Martínez-Lage, A. and Méndez, J. (2003). Cytogenetics of the razor clam Solen marginatus (Mollusca: Bivalvia: Solenidae). Cytogenetic and Genome Research, 101, 43-46.

López, J., Rodríguez, C. and Carrasco, J.F. (2005). Comparación del ciclo reproductor de Solen marginatus (Pulteney, 1799) (Mollusca: Bivalvia) en las rías del Eo y Villaviciosa (Asturias, noroeste de España): relación con las variables ambientales. Boletín. Instituto Español de Oceanografía, 21 (14), 317-327.

Orden de 22 de febrero de 2018, por la que por la que se establecen las tallas mínimas de captura y épocas de veda para los moluscos bivalvos y gasterópodos de la Comunidad Autónoma de Andalucía.

Peña, M., Royo, A., Ortiz, J. and Ruiz-Azcona, P. (2005). Localización de superficies aptas para el engorde de almejas en la zona intermareal del río Piedras (Cartaya, Huelva) (suroeste de la península Ibérica). Boletín. Instituto Español de Oceanografía, 21 (1-4), 343-351.

Pereira, A., Palanco, I., Rufino, M., Moreno, O. and Gaspar, M.B. (2007). La pesca de bivalvos en el litoral oceánico de la costa Suroccidental de la Península Ibérica. Colección Pesca y Acuicultura. Serie Recursos Pesqueros. Junta de Andalucía. Instituto de Investigación y Formación Agraria y Pesquera. Consejería de Innovación, Ciencia y Empresa. Consejería de Agricultura y Pesca.

Pérez-Hurtado, A. and Hortas, F. (2003). Programa de Sensibilización y Seguimiento Ambiental de las Comunidades de Aves e Invertebrados Bivalvos en la Península de los Toruños. El Puerto de Santa María. Instituto Mancomunado de la Bahía de Cádiz y Universidad de Cádiz.

Remacha-Triviño, A. (2005). Densidad, biometría y proporción de sexos de Solen marginatus (Pulteney, 1799) (Mollusca: Bivalvia) en la ría del Eo (noroeste de España). Boletín. Instituto Español de Oceanografía, 21 (1-4), 387-394.

Tirado, C., Rodríguez-Rúa, A., Bruzón-Gallego, M.Á., López-Linares, J.I., Salas-Casanova, C. and Márquez-Pascual, I. (2002). La reproducción de bivalvos y gasterópodos de interés pesquero en Andalucía. Colección Pesca y Acuicultura. Serie Recursos Pesqueros. Huelva. Junta de Andalucía. Consejería de Agricultura y Pesca. 


\title{
ANALYSIS AND CHARACTERIZATION OF DISCARDS IN THE GULF OF CÁDIZ (SW SPAIN). RESULTS OF THE ECOFISH PROJECT.

\author{
C. Rodríguez-García*1 ${ }^{1}$ F. Macías-Sánchez ${ }^{1}$ and R. Cabrera-Castro ${ }^{2}$
}

${ }^{1}$ Departamento de Biología, Facultad de Ciencias del Mar y Ambientales. Universidad de Cádiz. Avda. de la Universidad, 11510 Puerto Real, Cádiz, Spain. Campus de Excelencia Internacional del Mar (CEIMAR). carlos.rodriguezgarcia@alum.uca.es,felix.maciassanchez@alum.uca.es

${ }^{2}$ Instituto Universitario de Investigación Marina (INMAR). Campus de Excelencia Internacional del Mar (CEIMAR). Avda. de la Universidad, 11510 Puerto Real, Cádiz, Spain.

reme.cabrera@uca.es

\begin{abstract}
The new Common Fisheries Policy introduces the obligation to land all catches, including discarded species. Individuals that are thrown overboard, alive or not, due to, among other reasons, not being target species or not meeting legal sizes, are considered discards (Kelleher, 2008). The objective of this work was to characterize the species discarded in the fisheries of the Gulf of Cadiz, as well as, to make proposals for a better management of them. Sampling was carried out within the framework of the ECOFISH project, and shipments were made in the purse-seine and trawl modalities with the fleet of Sanlúcar de Barrameda (Cádiz) maintaining its way of fishing, from May to December 2019, except for the closed periods for both modalities, December in the case of purseseine and from mid-September to the end of October for the trawl modality in the Gulf of Cádiz. To this end, $11 \mathrm{~kg}$ of discards were processed and identified at random for each set made, at depths ranging from 20 to $270 \mathrm{~m}$. In the purse seine fishery, the main species discarded were bogue (Boops boops), atlantic chub mackerel (Scomber colias) and annular seabream (Diplodus annularis), while in the trawl fishery, both fish were discarded: anchovy (Engraulis encrasicolus), scaldfish (Arnoglossus spp.) and horse mackerel (Trachurus trachurus) as well as invertebrates: arrow shrimp (Plesionika heterocarpus), harbour crab (Liocarcinus depurator), white shrimp (Parapenaeus longirostris) and sand sea star (Astropecten irregularis). The low prices of some of these species and the low value of others are some of the causes of discards in this fishery. For a better management and reduction of discards, in addition to knowing the reasons why discards occur, the involvement of the different actors involved in the fishery is also necessary to ensure the successful incorporation of discard management measures under the new CFP.
\end{abstract}

Key words: Discards, trawling, seine, fisheries, stakeholders

Acknowledgments: The realization of the ECOFISH project has been possible thanks to 
the financing of the Fundación Biodiversidad, the Ministry for Ecological Transition, through the Pleamar Program, co-financed by the European Maritime and Fisheries Fund and above all by the collaboration of the fishermen who have welcomed us and allowed us to work side by side. We would like to thank all the boats that have been involved and the Cofradía de Pescadores Sanlúcar de Barrameda for their willingness.

\section{References:}

Kelleher, K. 2008. Discards in the World's Marine Fisheries: An Update. FAO Fisheries Technical Paper. Roma, FAO. 131 p. 


\title{
BIOENERGETIC OF SMALL PELAGIC FISHES: FATMETER ANALYSIS AS SURROGATE OF CALORIMETRY TO ESTIMATE ENERGY CONTENT OF EUROPEAN SARDINE AND EUROPEAN ANCHOVY
}

\author{
Claudia Campanini*1, Sara Gérez2, Marta Albo-Puigserver3, Elena Lloret-Lloret4, \\ Joan Giménezs, Jose Maria Bellidos and Marta Coll 7 \\ 1,2,3,4,5,7 Department of Renewable Marine Resources, Institute of Marine Science (ICM-CSIC), \\ Barcelona, SPAIN \\ claudiacampanini@hotmail.it,saragerezorus@gmail.com,albo@icm.csic.es,elloret@icm.csic.es, \\ joan.gimenez@csic.es,mcoll@icm.csic.es. \\ 6 Instituto Español de Oeanografía (IEO), Centro Oceanográfico de Murcia, San Pedro del Pinatar, \\ 30740, SPAIN \\ josem.bellido@ieo.es
}

\begin{abstract}
:
European sardine (Sardina pilchardus) and anchovy (Engraulis encrasicolus) are crucial species for the marine ecosystem of the NW Mediterranean Sea. They account for a high percentage of fish landings and they represent a relevant source of economic interest for the fishery sector (Palomera et al., 2007). Concerns over the stock status are raising in recent years as the abundance, growth, reproductive capacity and the body condition of both species are declining (Saraux et al., 2019). Energy storage variability has important implications for fish recruitment and population structure. Therefore, there is an urgent need for a continuous body condition monitoring. Direct condition indices, such as bomb calorimetry, are highly reliable, but extremely time-consuming methods to measure the energy content. Instead, indirect methods, such as fish Fatmeter (Distell, 2010) and relative condition index $(\mathrm{Kn})$ have been proposed as effective indirect methods to estimate fish condition (Schloesser \& Fabrizio, 2017; Brosset et al., 2015). The aim of this study is to assess the accuracy of Fatmeter and $\mathrm{Kn}$ index compared to direct bomb calorimetry for both small pelagic fishes. Individuals of both species were sampled monthly in Barcelona harbour during a full year, in order to assess seasonal variations. Our results highlight that both indirect indices were strongly correlated with calorimetry for sardine. Instead, a weaker correlation between Fatmeter and calorimetry was found for anchovy. The observed differences between the two species are related to their breeding strategies, being sardine a capital breeder that accumulates high quantities of fat in spring and summer, and anchovy an income breeder that accumulates less fat and has a lower seasonal variability in energy reserves (Albo-Puigserver et al., 2017; McBride et al., 2015). Based on this study, Fatmeter appears to be a faster and more suitable method to evaluate the energy content of sardines, while Kn could be a better indicator than Fatmeter for anchovy.
\end{abstract}


Key words: European anchovy, European sardine, Fatmeter, calorimetry, body condition.

Acknowledgments: This study was funded by PELWEB (ES-PN-2017-CTM2017-88939R) project. C.C. was funded by an Erasmus+ Mobility for Traineeships scholarship.

\section{References:}

Albo-Puigserver, M., Muñoz, A., Navarro, J., Coll, M., Pethybridge, H., Sánchez, S., \& Palomera, I. (2017). Ecological energetics of forage fish from the Mediterranean Sea: seasonal dynamics and interspecific differences. Deep Sea Research Part II: Topical Studies in Oceanography, 140, 74-82.

Brosset, P., Fromentin, J. M., Ménard, F., Pernet, F., Bourdeix, J. H., Bigot, J. L., ... \& Saraux, C. (2015). Measurement and analysis of small pelagic fish condition: a suitable method for rapid evaluation in the field. Journal of Experimental Marine Biology and Ecology, 462, 90-97.

Distell. 2010. User manual, Distell Fish Fatmeter Model FFM-992 and Model FFM-692. Distell, West Lothian, Scotland.

McBride, R. S., Somarakis, S., Fitzhugh, G. R., Albert, A., Yaragina, N. A., Wuenschel, M. J., ... \& Basilone, G. (2015). Energy acquisition and allocation to egg production in relation to fish reproductive strategies. Fish and Fisheries, 16(1), 23-57.

Palomera, I., Olivar, M. P., Salat, J., Sabatés, A., Coll, M., García, A., \& Morales-Nin, B. (2007). Small pelagic fish in the NW Mediterranean Sea: an ecological review. Progress in Oceanography, 74(2-3), 377-396.

Saraux, C., Van Beveren, E., Brosset, P., Queiros, Q., Bourdeix, J. H., Dutto, G., ... \& Fromentin, J. M. (2019). Small pelagic fish dynamics: A review of mechanisms in the Gulf of Lions. Deep Sea Research Part II: Topical Studies in Oceanography, 159, 52-61.

Schloesser, R. W., \& Fabrizio, M. C. (2017). Condition indices as surrogates of energy density and lipid content in juveniles of three fish species. Transactions of the American Fisheries Society, 146(5), 10581069 . 


\title{
SEASONAL SPATIAL PATTERNS OF A HIGHLY COMMERCIAL SPECIES RELATE TO PREY DISTRIBUTION AND TROPHIC BEHAVIOUR
}

\author{
Elena Lloret-Lloret ${ }^{1}{ }^{*}$, Joan Navarro ${ }^{1}$, Joan Giménez ${ }^{1,2}$, Nieves López ${ }^{1}$, Marta \\ Albo-Puigserver ${ }^{1}$, Maria Grazia Pennino ${ }^{3}$ and Marta Coll ${ }^{1}$ \\ ${ }^{1}$ Institut de Ciències del Mar (ICM-CSIC), Barcelona, SPAIN. \\ elloret@cmima.csic.es,joan@icm.csic.es,gimenez.verdugo@gmail.com, \\ nieves.lopez.nl@gmail.com,marta.albo.puigserver@gmail.com,mcoll@icm.csic.es \\ ${ }^{2}$ Centre for Marine and Renewable Energy (MaREI), Environmental Research Institute, University \\ College Cork, Ringaskiddy, Co. Cork, IRELAND. \\ gimenez.verdugo@gmail.com \\ ${ }^{3}$ Instituto Español de Oceanografía, Centro Oceanográfico de Vigo, SPAIN. \\ grazia.pennino@ieo.es
}

\begin{abstract}
Improving the knowledge on the biology, ecology and distribution of marine resources exploited by fisheries is absolutely needed to achieve population recovery and sustainable management. European hake (Merluccius merluccius) is one of the most important target species in the Mediterranean Sea and is largely overexploited (Lleonart and Maynou, 2003; Fernandes et al., 2017). Here, we combine two methodological approaches to further investigate seasonal variations in the spatial distribution of the median weight European hake considering ontogenetic changes. Our main aim is to assess if, beyond environmental factors, these changes are related to trophic behaviour. We have used a Bayesian hierarchal species distribution modelling approach (B-SDM), considering spatial median weight estimates from two oceanographic surveys conducted during winter and summer. We have analyzed how environmental variables, together with abundance and median weight distribution of the main preys identified for European hake, affect the median weight distribution of the species in winter and summer. Results show clear differences in median weight distribution of adults and juveniles between winter and summer, which were partially linked to the distributions of main preys, in addition to environmental variables. $\delta^{13} \mathrm{C}$ and $\delta^{15} \mathrm{~N}$ stable isotope values allowed examining the matching of these differences with seasonal differences in trophic habits and plasticity. For this, a Bayesian mass-balanced isotopic mixing models (MixSIAR) (Stock and Semmens, 2016) evinced substantial differences in trophic strategies between season and ontogenetic stage. This study illustrates how the combination of complementary methodologies provides a more complete understanding of species spatial ecology.
\end{abstract}

Key words: Species distribution models, Trophic structure, European hake 
Acknowledgments: E.L.-L. was supported by a FPU grant (FPU1704395, Spanish Ministry of Education) and J.N. by the Spanish National Program Ramon y Cajal (RYC-201517809). This study is a contribution of the ECOTRANS Project ("Dynamics and ecological role of small pelagic fishes in the North Western Mediterranean: energy transfer from planktonic organisms to top predators", CTM2011-26333, 2012-20141).

\section{References:}

Fernandes, P.G., Ralph, G.M., Nieto, A., Criado, M.G., Vasilakopoulos, P. et al. (2017). Coherent assessments of Europe's marine fishes show regional divergence and megafauna loss. Nature Ecology \& Evolution, 1, 0170 .

Lleonart, J. and Maynou, F. (2003). Fish stock assessments in the Mediterranean: state of the art. Scientia Marina, 67 (S1), 37-49.

Stock, B.C. and Semmens, B.X. (2016). MixSIAR GUI User Manual. Version 3.1. https://doi.org/doi:10.5281/zenodo.1209993 


\title{
VARIABILITY OF DIFFERENT SAMPLING METHODS APPLIED TO MARINE AQUACULTURE IMPACT MONITORING
}

\author{
Carbonell-Garzon E.*1 , Fernandez-Gonzalez V. ${ }^{2}$, Sanchez-Jerez $P^{3}$., Martínez Millán $G^{4}$, \\ Agraso M.M ${ }^{5}$.and Toledo-Guedes $\mathrm{K}^{6}$ \\ ${ }^{1,2,3,6}$ Department of Marine Sciences and Applied Biology, University of Alicante, Alicante, \\ SPAIN. \\ ecg62@alu.ua.es,victoria.fernandez@ua.es,psanchez@ua.es,kilian.toledo@ua.es
}

${ }^{4,5}$ Ctaqua - Fundación Centro Tecnológico Acuicultura de Andalucía, Muelle Comercial S/N, 11500, El Puerto de Santa María.

g.martinez@ctaqua.es,mm.agraso@ctaqua.es

\begin{abstract}
:
The increment of marine aquaculture production the last decades has generated a higher scientific interest on its impact on benthic ecosystems. The existence of several methodologies used for environmental monitoring plans at regional level as well as the wide heterogeneity of the measured parameters, have resulted in different conclusions about impact severity. Thus, in 2012, the Spanish National Advisory of Mariculture (JACUMAR) developed an initiative to evaluate the most important environmental variables for detecting fish-farm impact and to unify monitoring methodologies in Spain (Aguado-Gimenez et al., 2012). Thus, the main objective of this study is to advance in the knowledge and promotion of sampling protocols for their application in the monitoring programs for aquaculture industry. To this end, the specific aim of this study was to analyze the variability related to the use of different sampling methods such as scuba diving sampling, with quadrats and corers, or Van Veen grab. The study was carried out in two fish farms along the Spanish Mediterranean coast in summer 2019. According to JACUMAR protocol, in each location polychaete assemblages, total free sulphides (TFS) and the fine sediment fraction $(<0.063$ $\mathrm{mm}$ ) were analyzed.
\end{abstract}

Results showed a higher data aggregation for granulometry when corers were used, proving higher homogeneity in the collected sediment. In the same way, TFS were less variable when samples were collected by scuba divers using corers, probably due to the best conservation of sediment characteristics, preventing oxygenation of the sample. In the case of polychaeta assemblages, higher homogeneity was obtained when samples were obtained with Van Veen grab. According to these results, grab sampling may provide more homogeneous data for biological parameters, while the abiotic parameters are more homogeneous with scuba diving sampling in marine aquaculture environmental monitoring. However, it should be taken into account that the variability at the scale of meters is higher for fauna analysis than physico-chemical variables, which may suggest a preference use of the grab for monitoring samplings.

Key words: aquaculture, sampling methods, environmental monitoring, polychaete assemblages, abiotic parameters. 


\section{Acknowledgments:}

This study is part of the project "Modelos aplicados de capacidad de carga a la acuicultura marina (MACCAM)", which is carried out with the collaboration of Fundación Biodiversidad, of the Ministerio para la Transición Ecológica y el Reto Demográfico, through Pleamar Program, cofinanced by FEMP. We thank the collaboration of the three companies that gave us access to their facilities.

\section{References:}

Aguado-Gimenez, F., Carballeira-Ocaña, A., Collado-Sánchez, C., González-Henríquez, N. and SanchezJerez, P. (2012). Propuesta metodológica para la realización de los planes de vigilancia ambiental de los cultivos marinos en jaulas flotantes. Junta Nacional Asesora de Cultivos Marinos (JACUMAR). 


\title{
STUDY OF THE COMMON OCTOPUS FISHERY IN THE VALENCIAN COMMUNITY. PROPOSALS TO IMPROVE ITS MANAGEMENT
}

\author{
E. Arcas ${ }^{* 1}$, J.L. Sanchez ${ }^{1}$ and A. Esteban ${ }^{2}$ \\ ${ }^{1}$ Unidad de Biología Marina, Departamento de Ciencias del Mar y Biología Aplicada, Universidad \\ de Alicante, San Vicente del Raspeig, E-03080 Alicante, SPAIN. \\ jl.sanchez@ua.es,esther.arcas@ua.es \\ ${ }^{2}$ Ecosistemas Marinos Explotados - Pesca, Instituto Español de Oceanografía, Centro \\ Oceanográfico de Murcia, Murcia, SPAIN. \\ antonio.esteban@ieo.es
}

\begin{abstract}
The common octopus (Octopus vulgaris Cuvier, 1797) is a high value cephalopod resource. It's a difficult resource to manage due to its short life, semelparous life strategy, rapid growth, high natural mortality and sensitivity to environmental conditions, especially in the earliest stages of their life. These biological traits result in seasonal and interannual fluctuations in abundance and subsequent landings. In this work we have studied the evolution of catches, effort and CPUE of the octopus fishery in the Valencian Community (Spain). The main biological parameters and their reproductive cycle were estimated, fishery management was analyzed and measures were proposed to improve it. Annual catch and effort data and monthly catches have been analyzed for the trawl and pots fleet from 2009 to 2018 . We have also analyzed data from the MEDITS campaigns from 2012 to 2018. 1303 individuals from fishing landings with pots have been sampled since January until May 2019 providing the biological parameters of the species. A decrease in catches, effort and CPUE has been found in both fleets since 2011. Seasonality has been observed with maximum catches in Alicante and Valencia in springsummer, and in Castellón in autumn. The annual sex ratio (females: males) was 1: 1, and the monthly 1: 1.9 (January), 1: 1.9 (February), 1: 1.2 (March), 1: 0.9 (April) and 1: 0.8 (May). The weight of the individuals was higher in males, in shallow waters and in winter. Mature individuals reached a peak in May. The size and weight of first maturity in females was $123.1 \mathrm{~mm}$ and $1500 \mathrm{~g}$ respectively. The main concerns of the octopus fishermen with pots are the schedules, closures, number of allowed pots, simultaneity and interaction with trawl. Some suggestions are done to improve the existing regulation.
\end{abstract}

Key words: Octopus vulgaris, Common octopus, Pots, Fisheries management, Mediterranean Sea 


\title{
HARVEST RATE FOR THE ECOSYSTEM-BASED LIMIT REFERENCE POINT FOR THE THREAD HERRING FISHERY OF THE SOUTHERN GULF OF CALIFORNIA
}

\author{
Francisco Arreguín-Sánchez ${ }^{1}$ and Ik Rodríguez-Vite ${ }^{1}$ \\ ${ }^{1}$ Laboratorio de Dinámica de Ecosistemas y Poblaciones Explotadas, Instituto Politécnico \\ Nacional-Centro Interdisciplinario de Ciencias Marinas, La Paz, Baja California Sur, MÉXICO. \\ farregui@ipn.mx,ikrodriguezvite@gmail.com
}

\begin{abstract}
One of the major scientific challenges for managing a fishery resource is to address the question of how much biomass should remain at sea, after fishing, to maintain ecosystem functioning. This concept has special interest for commercial species that occupy the base of the food pyramid and are affected by environmental variability, such as small pelagic species. We present an application of a concept termed as noxicline that identify the limit of harvesting of a species after which the ecosystem organization change without chance of recovery. The basic concept is that the ecosystem gains entropy when biomass decrease, in our case because of fishing. If harvesting is increases gradually, the inflexion point in the change-of-entropy's tendency will represent the critical limit of fishing, interpreted as the ecosystem-based limit reference point (ELRP) associated to the impacted species. Our study case id the thread herring (Opisthonema spp.) fishery in the southern Gulf of California which is the target species for the fishing industry in that region. We base our analysis in an ecosystem trophic model that represents the flows of energy of about 90 functional groups including a wide range of trophic levels and representing also all fished stocks. We adjust the model to a non-exploited ecosystem condition and simulate the effect on entropy of an increasing harvest rate, HR, understanding $\mathrm{HR}$ as the proportion of catch respect the available biomass. Then the tendency of the change in entropy was got and the inflexion point estimated. Our results show that, for the thread herring the ELRP corresponds to a HR $=0.41$, suggesting that a remaining biomass at the sea lower than $59 \%$ will promote changes in ecosystem organization and function which could not be recover.
\end{abstract}

Key words: Ecosystem reference point, Thread herring, Entropy, Noxicline, Gulf of California 


\title{
APPROACH TO THE DIGESTIVE ONTOGENY FOR THE CULTURE OF PACIFIC PYGMY OCTOPUS
}

\author{
M. Sánchez-Torres ${ }^{1}$, P. Ceballos-Vázquez ${ }^{1}$ and P. Gallardo-Espinosa ${ }^{2}$ \\ ${ }^{1}$ Laboratorio de Invertebrados Marinos, Instituto Politécnico Nacional-Centro Interdisciplinario de \\ Ciencias Marinas, La Paz, Baja California Sur, MÉXICO. \\ magalli.science@gmail.com,bceballo@ipn.mx \\ ${ }^{2}$ Unidad Multidisciplinaria de Docencia e Investigación, Facultad de Ciencias, UNAM, Sisal, \\ Yucatán, MÉXICO. \\ ppge@ciencias.unam.mx
}

\begin{abstract}
The lack of a suitable food for octopuses in the early stages post hatching (PH) is a limitation for their commercial aquaculture. Knowing the use of nutritional reserves and the activity of digestive enzymes during this stage allows developing and implementing specific diets. The Pacific Pygmy Octopus Paroctopus digueti was used as a model due to its direct development and quick growth, with high potential for culture. Brooding females were collected from the natural environment, which were placed in conditions of captivity until the hatching of the eggs. The obtained hatchlings were kept in individual containers, fed with fresh crab meat and samples were taken the day of hatching and every two days until day 14 . The digestive gland (DG) was isolated, as well as muscle (M) from the arms an evaluation of alkaline and acidic proteolytic activity, lipases in DG. The quantification of soluble protein and glycogen content in DG and $\mathrm{M}$, were done. The results obtained from the activity of digestive enzymes (acidic proteases $\bar{x}=4656 \pm 825.8 \mathrm{U} \mathrm{mg}$ protein-1 day $4 \mathrm{PH}$ ) and the content of nutritional reserves of $P$. digueti help us to observe an apparent process of adaptation to exogenous food and a mobilization of reserves between day 2 and 4 after the hatching (soluble protein GD $\bar{x}=27.9 \pm 0.9 \mathrm{mg}-1$ day $4 \mathrm{PH}$ ), which may reflect a high metabolism and dependence of exogenous food as has been observed in other species of octopuses with direct development. These results bring us closer to find a formulated diet for this octopus, which would help to diversify the culture octopus species.
\end{abstract}

Key words: Lipases, Proteases, Glycogen, Soluble protein, Octopus culture 


\title{
EFFECT OF THE INTAKE OF ADDITIONAL SOLUBLE PROTEIN ON THE GROWTH, SURVIVAL AND METABOLIC RESERVES IN JUVENILES OF THE RED OCTOPUS, OCTOPUS MAYA
}

\author{
M. Sánchez-Torres ${ }^{1}$, P. Gallardo-Espinosa ${ }^{2}$, A. Sánchez ${ }^{2}$, P. Ceballos-Vázquez ${ }^{1}$, C. \\ Rosas $^{2}$ and C. Pascual ${ }^{2}$ \\ ${ }^{1}$ Laboratorio de Invertebrados Marinos, Instituto Politécnico Nacional-Centro Interdisciplinario de \\ Ciencias Marinas, La Paz, Baja California Sur, MÉXICO. \\ magalli.science@gmail.com,bceballo@ipn.mx \\ ${ }^{2}$ Unidad Multidisciplinaria de Docencia e Investigación, Facultad de Ciencias, UNAM, Sisal, \\ Yucatán, MÉXICO. \\ ppge@ciencias.unam.mx,ariadna.sanchez@gmail.com,crv@ciencias.unam.mx \\ ,pascual.cristina@ciencias.unam.mx
}

\begin{abstract}
The effect of soluble fish protein (PS) on the growth, survival, protein and glycogen content in arm muscle and digestive gland of Octopus maya juveniles was evaluated for 72 days. For this, 3 levels of fish PS (10, 15 and 20\%) were added to pelletized diet (Patent MX /a /2011/005278) according to the modified formulation of Martínez et al. (2014) and as a control the pelletized diet without protein addition was used. No significant differences in growth were observed $(P>0.05)$ and a mean specific growth rate of $4.08 \%$ day- 1 was determined. However, in the octopuses subjected to the diets with 15 and $20 \%$ PS, significant higher survival rates (mean $80 \%$ ) were observed compared to that obtained $(65 \%)$ with the control diet $(P<0.05)$. Similarly, in muscle, the octopuses fed with the diets added with PS had a significant higher $(P<0.05)$ glycogen content (mean $0.59 \mathrm{mg}$ g- 1 ) than that of the control ones $(0.33 \mathrm{mg}$ g- 1$)$. On the contrary, no differences $(P>0.05)$ were found in the total protein content (mean $120 \mathrm{mg} \mathrm{mL}-1)$ in the muscle or the glycogen content in the digestive gland (mean $3.48 \mathrm{mg}$-1) of the experimental organisms. According to the results, a higher consumption of soluble protein favors the survival and accumulation of glycogen in the arm muscle. In conclusion, the addition of soluble protein to the diet generates a beneficial effect on the nutrition and metabolism of juveniles of $O$. maya.
\end{abstract}

Key words: Pelletized diet, Survival rate, Glycogen, Soluble protein

\section{References:}

Martínez, R., Gallardo, P., Pascual, C., Navarro, J., Sánchez, A., Caamal-Monsreal, C., y Rosas, C. 2014. Growth, survival and physiological condition of Octopus maya when fed a successful formulated diet. Aquaculture, 426, 310-317. 


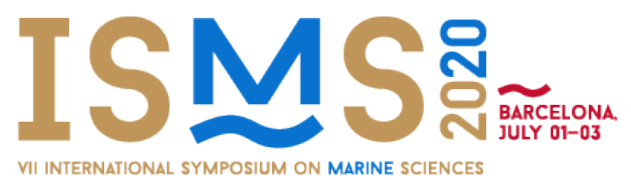

VII International Symposium on Marine Sciences

ISMS 2020

Barcelona (Spain), $1^{\text {st }}-3^{\text {rd }}$ July 2020

\section{MERCURY ACCUMULATION IN MEDITERRANEAN LEAN FISH}

\author{
Joan O. Grimalt**1, Marco Capodiferro ${ }^{2}$ \\ Department of Environmental Chemistry, Institute of Environmental Assessment and Water \\ Research (IDAEA-CSIC), Barcelona. \\ 1joan.grimalt@idaea.csic.es, 2marco.capodiferro@idaea.csic.es
}

\begin{abstract}
The Mediterranean Sea is a water body with much higher mercury pollution than in equivalent marine environments that receive inputs of this metal from the general atmospheric fallout. Fish mercury is primarily associated with muscle tissue rather than fat which, besides oily fish, points to predatory species, e.g. lean fish, for the accumulation of this metal. The present study is devoted to determine the concentrations of total mercury and methylmercury in a great variety of lean fish species from the Western Mediterranean Sea and to determine how consumption of these specimens contribute to the total mercury intake in human populations.

1350 commercial seafood samples from the Western Mediterranean Sea were collected (Feb 2014-December 2019) in several sites such as Mallorca, Menorca, Eivissa, Alacant (Spain), Marseille (France), Genoa, Alguer, Civitavecchia (Italy). Samples from Egypt and the Atlantic Ocean (Senegal, Mauritania coasts) were also taken for comparison. Fish species were selected considering those most consumed by the population.

Comparison of the mercury concentrations in specimens of the same fish species collected at different sites revealed the location of the excess hot spots of this metal in comparison to the atmospheric fallout which allowed the identification of the source processes.

A considerable number of the analyzed fish species exceeded the maximum levels proposed by the European legislation for human consumption, such as dusky grouper $(100 \%$ of the examined specimens), common dentex (65\%), conger $(45 \%)$, common sole $(38 \%)$, hake $(26 \%)$ and angler $(15 \%)$, among others.

The average $\mathrm{THg}$ intake due to fish consumption, $0.61 \mu \mathrm{g} / \mathrm{g}$ ww, involved $\mathrm{Hg}$ estimated weekly intakes of $5.7 \mu \mathrm{g} / \mathrm{kg}$ bw for children aged 7-12 years and $4.4 \mu \mathrm{g} / \mathrm{kg}$ bw for adults. These values were higher than the provisional tolerable weekly intakes recommended by $\mathrm{FAO} / \mathrm{WHO}, 4 \mu \mathrm{g} / \mathrm{kg}$ bw. Thus, the excess of $\mathrm{Hg}$ intake corresponds to $140 \%$ and $110 \%$, respectively, if only local Mediterranean fish is consumed.
\end{abstract}

Key words: Mercury, commercial fish, western Mediterranean, human mercury intake 


\title{
A NEW SUSCEPTYBILITY TO FISHING INDEX: PRELIMINARY RESULTS TO EVALUATE THE STATE OF EXPLOITATION OF TARGET AND BY-CATCH SPECIES OF THE BALEARIC ISLANDS BOTTOM-TRAWL FISHERY
}

\author{
M. Bibiloni ${ }^{1}$, B. Guijarro ${ }^{2}$, F. Ordinas ${ }^{2}$ and M.T. Farriols ${ }^{2}$ \\ ${ }^{1}$ Universitat de les Illes Balears, Palma, SPAIN. \\ marinabibilonisocias@gmail.com \\ ${ }^{2}$ Instituto Español de Oceanografía - Centre Oceanogràfic de Balears, Palma, SPAIN. \\ beatriz.guijarro@ieo.es,xisco.ordinas@ieo.es,mt.farriols@ieo.es
}

\begin{abstract}
Mediterranean fisheries are characterized by their multi-species nature. Many of the species caught are not regularly assessed and therefore information on their status is scarce. The present study uses data from the MEDITS bottom trawl survey to evaluate the state of exploitation of both target and the most important by-catch species of the bottom trawl fishery of the Balearic Islands. For this purpose, the information obtained during the MEDITS surveys from 2003 to 2019 has been used. We used generalized additive models (GAMs) to model the distribution of the abundance of the analyzed species considering sampling station depth, location and year as explanatory variables. In order to take into account zero-inflated data, a two-step procedure was adopted, using two GAM models for abundance in presence-only samples and for presence-absence data, separately. Model results were used to predict abundance over a spatial grid covering the whole study area considering the year, and the depth and location of each $1 \mathrm{~km}^{2}$ cell of the grid. A fishing susceptibility index (SI) was developed using fishing effort (daily fishing trips calculated from Vessel Monitoring Satellite system data) and species distributions across their habitats. Specifically, the SI considers not only the fishing effort but how it is distributed across the different levels of abundance that a species can present within its habitat. The annual trend (2003-2019) of the SI of each selected species is compared to its temporal trend of abundance and frequency of occurrence (from empirical data) within its habitat and to the temporal trend of the predicted extension of its habitat (given by the model). Our results show that the SI developed can be a useful tool to predict how the fishing effort variability can affect the state of exploited species.
\end{abstract}

Key words: Fishing effort, Bottom trawling, Susceptibility, Balearic Islands, Western Mediterranean

Acknowledgments: MEDITS surveys are co-funded by IEO and the EU through the European Maritime and Fisheries Fund (EMFF) within the National Program of collection, management and use of data in the fisheries sector and support for scientific advice regarding the Common Fisheries Policy. 


\title{
ABUNDANCE AND DISTRIBUTION OF THE DEEP-SEA BLUE AND RED SHRIMP ARISTEUS ANTENNATUS LARVAE ALONG THE SPANISH MEDITERRANEAN COAST
}

\author{
M. Carreton**1, J.B. Company ${ }^{1}$, F. Sardà ${ }^{1}$ and G. Rotllant ${ }^{1}$ \\ ${ }^{1}$ Departament de Recursos Marins Renovables, Institut de Ciències del Mar (ICM-CSIC), \\ Barcelona, SPAIN. \\ mcarreton@icm.csic.es, batista@icm.csic.es,francisco.sarda@gmail.com,guio@icm.csic.es
}

\begin{abstract}
The deep-sea red shrimp Aristeus antennatus (Risso, 1816) is one of the most valuable fishing resources in the Northwestern Mediterranean Sea, currently under a local co-management plan in the port of Palamós (Spain). The current management measures, although effective, might benefit other ports downstream due to the dispersal patterns of the species pelagic larvae. Gathering information about $A$. antennatus larval distribution is a key step to observe these patterns and accurately define the species fishing stock, towards the establishment of well-dimensioned management measures. Here we present the spatial distribution of $A$. antennatus larvae at the peak of the species spawning period (July to August) along the Spanish Mediterranean coast. Zooplankton sampling was carried out at 101 stations in surface waters ( 0.5 to $1 \mathrm{~m}$ depth) in summer 2016 with a $1 \mathrm{~m}$ mouth neustonic sledge over continental margin areas from 82 to $1840 \mathrm{~m}$ depth. Samples were preserved in $96 \%$ ethanol and sorted in the laboratory under a stereomicroscope. Identification of the larvae was done according to the available taxonomic literature. Satellite oceanographic data were also collected from the Copernicus Marine Environmental Monitoring System (CMEMS). Over 2500 A. antennatus larvae of all known stages were found in our samples, the first protozoea representing almost $90 \%$ of the total. Results show aggregations of larvae in the Ibiza Channel and in the northern submarine canyons of the Catalan margin, concurrent with hydrographic conditions. No larvae were found south of the Ibiza Channel. These data shed new light on the species larval dispersal and validate a biohydrodynamic model of the study area. Moreover, the present study will inform the planning and scaling of management measures for the species in the studied area.
\end{abstract}

Key words: Aristeus antennatus, Larvae, Ecology, Fisheries, Mediterranean Sea

Acknowledgments: MC was funded by the Spanish Ministerio de Educación through the FPU2015 program. This research is part of the CONECTA project, funded by the Spanish Ministerio de Economía y Competitividad. 


\title{
VERY LONG-CHAIN (>C24) POLYUNSATURATED FATTY ACIDS IN MARINE FISH: NUTRITIONAL REGULATION OF GENES INVOLVED IN THEIR BIOSYNTHESIS IN Sparus aurata AND Solea senegalensis
}

\author{
M. Torres, J.C. Navarro, Ó. Monroig, I. Varó, and F. Hontoria \\ Instituto de Acuicultura de Torre de la Sal (IATS-CSIC), Ribera de Cabanes (Castellón), SPAIN. \\ miguel.torres.rodriguez@csic.es, jcnavarro@iats.csic.es,oscar.monroig@csic.es, \\ inma@iats.csic.es,hontoria@iats.csic.es.
}

\begin{abstract}
Very long-chain $\left(>\mathrm{C}_{24}\right)$ polyunsaturated fatty acids (VLC-PUFA), although present in small amounts, play important roles for the correct development and functionality of neural tissues, especially during early development of vertebrates [1]. However, studies on VLC-PUFA in fish are scarce. Their biosynthesis, mediated by elongation of very long-chain fatty acid 4 (Elovl4) proteins, is substrate-dependent. So, shorter fatty acid precursors, i. e. long-chain $\left(\mathrm{C}_{20-24}\right)$ polyunsaturated fatty acids (LCPUFA), are required. These nutrients are mostly incorporated by the diet and their bioavailability can determine the capacity of Elovl4 for satisfying the physiological VLCPUFA demands in marine fish [2]. Thus, nutritional regulation of Elovl4, as well as other elongase and desaturase genes involved in LC-PUFA biosynthesis (Elovl5, Fads2) has been proposed as a strategy to enhance endogenous production of LC-PUFA and VLCPUFA in fish farming [2]. This study aimed at investigating the nutritional regulation of genes involved in the biosynthesis of VLC-PUFA (elovl $4 a$, elovl $4 b$ ) and LC-PUFA ( fads2, elovl5) in early life-cycle stages (larvae and post-larvae) of Sparus aurata and Solea senegalensis fed diets adapted to each development stage, live prey for larvae and microdiets for post-larvae, with a variable content in VLC-PUFA precursors, i.e. LCPUFA. The results denoted that fads2, elovl5, elovl $4 a$ and elovl $4 b$ genes can be regulated by dietary LC-PUFA content. It is important to highlight that elovl4a and elovl4b genes, strongly expressed in neural tissues of both fish species, were differently regulated according to the species-specific VLC-PUFA putative needs associated with each early life-stage and the LC-PUFA dietary availability. These results can help to elucidate the molecular mechanism controlling the VLC-PUFA biosynthesis and their species-specific requirements along of the marine fish development. Thus, this study opens the possibility to incorporate successfully alternative lipid sources, through an early nutritional programming that stimulates the VLC-PUFA biosynthesis during the first exogenous feeding stages.
\end{abstract}

Key words: Sparus aurata, Solea senegalensis, very long-chain polyunsaturated fatty acids, Elovl4, nutritional regulation. 
Acknowledgments: This research was funded by the projects AGL 2013-40986-R (Spanish Government, Ministry of Economy and Competitiveness), and PROMETEO II / 2014/085 (Generalitat Valenciana). Miguel Torres was supported by a $\mathrm{PhD}$ funding program from Diputación de Castellón.

\section{References:}

[1] Deák, F., Anderson, R.E., Fessler, J.L. and Sherry, D.M. (2019). Novel cellular functions of very long chain-fatty acids : Insight from ELOVL4 mutations. Frontiers in Cellular Neuroscience, 13, 428.

[2] Torres, M., Navarro, J.C., Varó, I., Agulleiro, M.J., Morais, S., Monroig, Ó. and Hontoria, F. (2020). Expression of genes related to long-chain $(\mathrm{C} 18-22)$ and very long-chain $(>\mathrm{C} 24)$ fatty acid biosynthesis in gilthead seabream (Sparus aurata) and Senegalese sole (Solea senegalensis) larvae : investigating early ontogeny and nutritional regulation. Aquaculture, 520, 734949. 


\title{
ESTIMATION OF THE POTENTIAL SPATIAL DISTRIBUTION OF SPECIES CAUGHT BY THE ARTISANAL FLEET OFF THE YUCATAN PENINSULA
}

\author{
R. López-Salazar**1 ${ }^{1}$ E. Torres-Irineo ${ }^{2}$ and J.A. López-Rocha ${ }^{3}$ \\ ${ }^{1}$ Posgrado en Ciencias del Mar y Limnología, Mérida, MÉXICO. \\ rls@ciencias.unam.mx \\ ${ }^{2}$ Escuela Nacional de Estudios Superiores, Mérida, MÉXICO. \\ edgar.torres@ciencias.unam.mx \\ ${ }^{3}$ Unidad Multidisciplinaria de Docencia e Investigación, Sisal, MÉXICO. \\ jorgelopezrocha@ciencias.unam.mx
}

\begin{abstract}
The spatial distribution of the fishing effort is a highly relevant component for the management of artisanal fisheries, which may allow identifying potential fishing areas characterized by species assemblages captured by a given fishing gear. Here we analyse two of the most important fishing methods and associated gear used in the Yucatan coast, "jimba" and diving with compressor.
\end{abstract}

Data was collected in the ports of Sisal, Dzilam de Bravo and Rio Lagartos from May 2017 to June 2018. Observers on board fishing vessels recorded the routes of the vessels with GPS and the species caught, both in terms of weight and abundance.

The study was divided into two stages: 1) Characterization of the fishing assemblages, which allowed evaluating differences in the composition of species by fishing gear for the three ports; 2) Construction of a species distribution model to assess the environmental characteristics determine habitat suitability. Data from stage 1) were analysed by means of multivariate tests such as NMDS and PERMANOVA, the composition of the assemblages was characterized with the IndVal (Indicator Value) method. For stage 2) we used the BIOMOD platform to build assembled models, such as GLM, GAM, GBM, MARS, RF, CART and MaxEnt, among others. Some of the environmental variables that were considered are current speed, temperature, salinity, diffusion coefficient and chlorophyll concentration. The results highlight differences between Sisal and the ports of Dzilam de Bravo and Rio Lagartos in fishing by diving with compressor.

Key words: Spatial distribution models, BIOMOD, PERMANOVA, Fishing assemblages, Artisanal fisheries

Acknowledgments: Interinstitucional proyect (EPOMEX, Campeche; UMDI-Sisal, UNAM; Cinvestav-IPN Mérida) "Caracterización de la pesca artesanal en la Península de Yucatán: Identificando unidades de manejo". 


\title{
PRELIMINARY RESULTS ON THE EUROPEAN SARDINE CONDITION
}

\author{
X. Frigola-Tepe*1, S. Lara-Rull ${ }^{2}$, A. Serrat ${ }^{2}$, J. Viñas ${ }^{1}$, M. Muñoz ${ }^{2}$ \\ 1, Department of Biology, University of Girona, Girona, SPAIN. \\ xeniafrigola@gmail.com,jordi.vinas@udg.edu \\ ${ }^{2}$ Department of Environmental Sciences, Institute of Aquatic Ecology, University of Girona, \\ Girona, SPAIN. \\ sonialarar@gmail.com,alba.serrat@udg.edu,marta.munyoz@udg.edu
}

\begin{abstract}
Sardine (Sardina pilchardus) is a species with an important commercial interest. Its distribution comprises the Mediterranean Sea and also the majority of the East Atlantic Ocean (Parrish et al. 1989). In recent years, there has been a decrease in catches throughout their distribution, accompanied by a reduction in their total size, their maturation size and their lipid reserves (Brosset et al. 2016; Van Beveren et al. 2014). Currently, sardine is considered being in a critical situation.

In this context, our aim is to evaluate the health status of sardine in four different areas of the Mediterranean Sea (Catalan coast, Alboran Sea, Aegean Sea and Adriatic Sea) and to compare it with sardines captured in the North East Atlantic. We analysed 100 specimens from each of the mentioned locations caught between October and December, when the gonads are being developed. General morphogravimetric data was measured, sex and gonad development stage of each individual was determined, and also the fat content of their tissues was estimated.
\end{abstract}

The percentage of mesenteric fat in the cavity of sardine was determined using a visual scale; the total lipid percentage was measured with a Distell Fish Fat Meter; and the Le Cren Condition Factor $(\mathrm{Kn})$ was calculated based on total size and eviscerate weight.

Most of the specimens showed gonads in developing, regenerating and spawning phase. Preliminary results show higher Kn, higher lipid percentage and higher mesenteric fat in the Atlantic specimens, pointing out a better condition in Atlantic sardines than in the Mediterranean sardines.

Key words: sardine, condition, fat content, health status, Mediterranean

Acknowledgments: This work is part of the program ConSarVar (Analysis of genomic variability and condition of Sardine populations in the Mediterranean Sea. Involvement in fishery management) and funded by the Spanish Ministry: State Plan for Scientific and 
Technical Research and Innovation: 2017-2020. Ref. RTI2018-097544-B-100. Co-financed by the European Maritime and Fisheries Fund (FEMP).

\section{References:}

Brosset P., Lloret J., Muñoz M. et al. 2016. Body reserves mediate trade-offs between life-history traits: new insights from small pelagic fish reproduction. Royal Society Open Science 3: 160202. http://dx.doi.org/10.1098/rsos.160202

Parrish R.H., R. Serra, W.S. Grant. 1989. The monotypic sardines, Sardina and Sardinops: their taxonomy, stock structure, and zoogeography. Canadian Journal of Fisheries and Aquatic Sciences, 46: 2019-2036.

Van Beveren E., Bonhommeau S., Fromentin J.M., et al. 2014. Rapid changes in growth, condition, size and age of small pelagic fish in the Mediterranean. Marine Biology, 161: 1809-1822. 


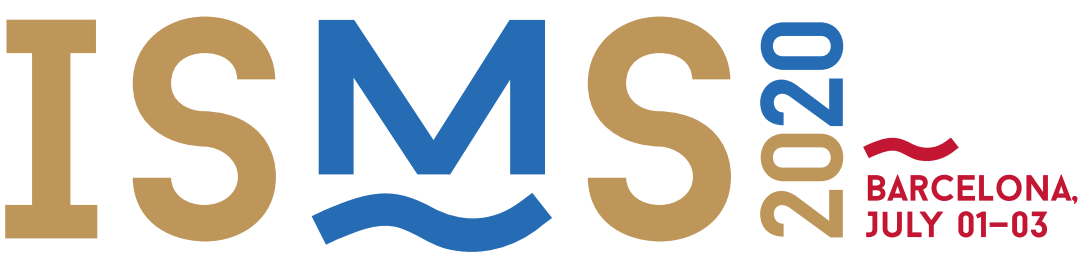

VII INTERNATIONAL SYMPOSIUM ON MARINE SCIENCES BARCELONA

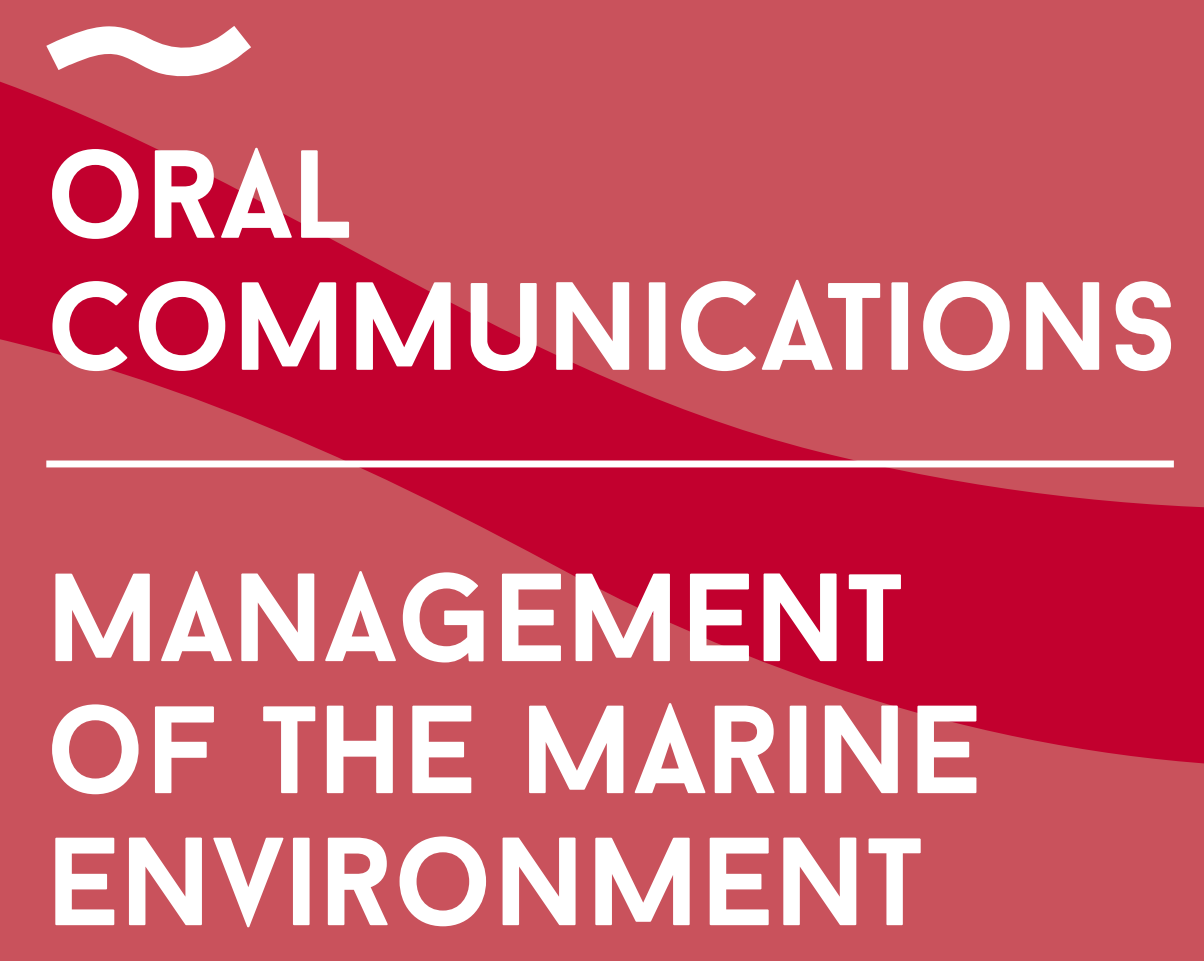




\title{
OCCURRENCE OF EU WATCH LIST SUBSTANCES IN WASTEWATER AND RECEIVING WATER WITHIN THE BASQUE ESTUARIES AND COAST
}

\author{
Oihana Solaun ${ }^{1}$, Joana Larreta ${ }^{1}$, Iratxe Menchaca ${ }^{1}$, José Germán Rodríguez ${ }^{1}$, Ester \\ López-García $^{2}$, Elena Martínez ${ }^{2}$, Bozo Zonja ${ }^{2}$, Cristina Postigo ${ }^{2}$, Miren López de \\ Alda $^{2}$, Damià Barceló ${ }^{2}$, Ángel Borja ${ }^{1}$ y Alberto Manzanos ${ }^{3}$ \\ ${ }^{1}$ Marine Research Division, AZTI, Herrera Kaia, Portualdea z/g, 20110 Pasaia, Spain. \\ osolaun@azti.es,jlarreta@azti.es \\ ${ }^{2}$ Department of Environmental Chemistry, IDAEA-CSIC, C/Jordi Girona 18-26, 08034 Barcelona, \\ Spain. \\ ${ }^{3}$ Basque Water Agency (URA), Orio 1-3, 01010 Vitoria-Gasteiz, Spain.
}

\begin{abstract}
:
The study of the presence in the aquatic environment of certain substances considered as contaminants of emerging concern (CEC) is a preliminary step to the analysis of the possible harmful effects on aquatic ecosystems and the establishment of the corresponding environmental quality standards. In order to monitor the occurrence of CECs in the aquatic environment, the European Commission had established in 2015 and 2018 two watch-list of substances for Union-wide monitoring in the field of water policy (Decision (EU) 2015/495 and Decision (EU) 2018/840). In the coast of the Basque Country, southeast of the Bay of Biscay, from May 2017 to November 2018, 20 of the substances mentioned were monitored quarterly in three wastewater treatment plants (WWTPs) and in five control points associated with receiving waters of three transitional water bodies and a coastal water body. The most frequently quantified substances were azithromycin (91\%), imidacloprid (82\%), clarithromycin (80\%), diclofenac (78\%) and erythromycin $(73 \%)$, with frequency of quantification ${ }^{1}$ higher in wastewaters $(71-100 \%)$ than in receiving waters. In general, concentrations in wastewater were also higher than in receiving waters, indicating a dilution effect in the environment. In receiving waters, five of the considered substances exceeded their respective Predicted No-Effect Concentrations (PNEC) (Loos et al 2018): azithromycin (34\%), imidacloprid (9\%), clarithromycin (7\%), ciprofloxacin (7\%) and diclofenac 5\%; and therefore, these levels could represent an environmental risk.
\end{abstract}

Key words: EU Watch List substances, wastewater, receiving water.

\section{Acknowledgments:}

\footnotetext{
${ }^{1}$ The percentage of cases that exceed the quantification limit versus the total number of cases analysed.
} 
This work was supported by the Basque Water Agency (URA) through the project "Network for monitoring the ecological and chemical status of transitional and coastal waters of the Basque coast". The authors acknowledge the help of the entities in charge of the management of the three studied WWTPs (Consorcio de Aguas Bilbao Bizkaia, Consorcio de Aguas de Busturialdea and Aguas del Añarbe).

\section{References:}

Loos, R., D. Marinov, I. Sanseverino, D. Napierska, T. Lettieri (2018). Review of the 1st Watch List under the Water Framework Directive and recommendations for the 2nd Watch List (https://ec,europa,eu/jrc). 


\title{
BALLAST WATER DISCHARGE PROFILE OF LAS PALMAS PORT AS AN INPUT FOR RISK ASSESSMENT AND MANAGEMENT IN THE ATLANTIC AREA: PRELIMINARY RESULTS
}

\author{
P. Nantois ${ }^{1}$, M. D. Gelado-Caballero ${ }^{1}$, C. Collado-Sánchez ${ }^{1}$ and M. N. Hernández- \\ Artiles $^{2}$ \\ ${ }^{1}$ Department of Chemistry, University of Las Palmas de Gran Canaria, Las Palmas de Gran \\ Canaria, SPAIN. \\ perrine.nantois@ulpgc.es,maria.gelado@ulpgc.es,cayetano.collado@ulpgc.es \\ ${ }^{2}$ Department of Safety, Protection and Environment, Port Authority of Las Palmas, Las Palmas de \\ Gran Canaria, SPAIN. \\ mnhernandez@palmasport.es
}

\begin{abstract}
In order to facilitate the fast and efficient implementation of the Ballast Water Management Convention (IMO, 2007) adopted by the international maritime organization in 2004, and in particular the Exemptions to ballast water management (Regulation A-4), the @BlueportS project proposes to help the decision-makers by elaborating a risk assessment model applicable to the ports of the Atlantic area. One of the associated risk parameters is the probability of introduction of non-indigenous species in the new ecosystem, that can be mainly evaluated by the average volume per discharge (V/D) and the number of discharge events (ND) of ballast water (BW).
\end{abstract}

This study has established the discharge profile of Las Palmas port using a generic ballast water discharge assessment model (David et al. 2012) with the aim of recommending a model for assessing the V/D and the ND, and hence, the probability of introduction.

In this work, a period of 24 months of shipping data of Las Palmas port has been analysed. A total of 698728 tons of BW discharge as a consequence of 821 discharge events has been estimated. The percentage of vessel calls that would have discharged BW are much lower compared to other ports (i.e. $4 \%$ compared to $38 \%$ in Hamburg Port and $61 \%$ in TallinMuuga port) which validates the cargo receiver profile of Las Palmas port. Moreover, the average V/D and ND is highly variable depending of the type of vessel although the Oil/Chemical tankers present a high probability of introduction. These preliminary results show the adequacy of the model selected for assessing one of the risk parameters of bioinvasion in the Atlantic area, thanks to the input data easily obtainable and the consistency of the results. The data obtained can also be appreciated for the dimensioning of a port reception facility system.

Key words: Bioinvasion risk, Ballast water, Maritime transportation, Non indigenous species (NIS) 
Acknowledgments: This work is part of the @BlueportS (Discharge of polluted water at port, not at Sea) project, and was supported by European Regional Development Funds, INTERREG Atlantic Area.

\section{References:}

David, M., Perkovič, M., Suban, V., and Gollasch, S. (2012). A generic ballast water discharge assessment model as a decision supporting tool in ballast water management. Decision support systems, 53 (1), 175185.

IMO (2007). Guidelines for Risk Assessment under Regulation A-4 of the BWM Convention (G7). Marine Environment Protection Committee, Resolution MEPC.162(56), 13 July 2007. International Maritime Organization, London (16 pp). 


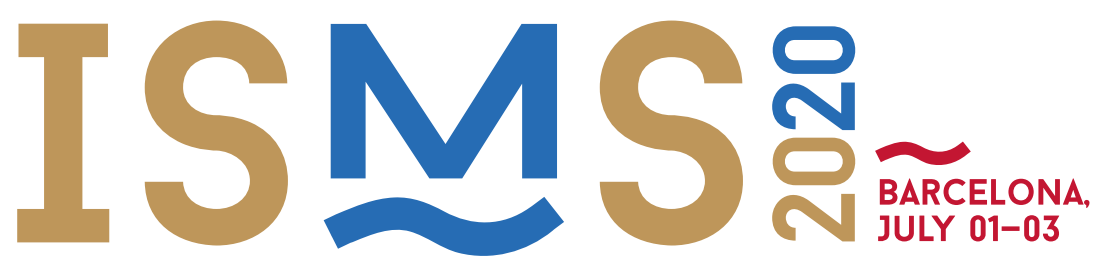

VII INTERNATIONAL SYMPOSIUM ON MARINE SCIENCES BARCELONA
JULY 01-03

ORAL COMMUNICATIONS

\section{MARINE} BIODIVERSITY 


\title{
BIODIVERSITY IN ANTHROPIZED MARINAS: THE CASE OF THE BATH AREA OF FORUM DE BARCELONA (SPAIN)
}

\author{
A. Parera**1 ${ }^{1}$, M. Ballesteros ${ }^{1}$ and M. Pontes ${ }^{2}$ \\ ${ }^{1}$ Departament de Biologia Evolutiva, Ecologia i Ciències Ambientals, Universitat de Barcelona, \\ 08020 Barcelona, SPAIN. \\ alexgarciaparera97@gmail.com,mballesteros@ub.edu \\ ${ }^{2}$ Grup d'Estudis VIMAR (Vida Marina) \\ miquelpontes@gmail.com
}

\begin{abstract}
The Mediterranean Sea is a hotspot of biodiversity and endemisms (between 4\% and $18 \%$ of species are endemic, depending on the groups -Coll et al., 2010-), but this favourable environment for native species is also good for the settlement of exotic species (Ferrario et al., 2017). The lack of data from highly impacted marine ecosystems led us to conduct a biodiversity study of the bath area of Forum de Barcelona, an urban artificial beach that receives large amounts of waste from neighbouring areas and sewer pipes produced by the nearby Besòs sewage treatment plant. As the conditions are eutrophic we did not expect to find many species, but results revealed a surprisingly rich marine life with 359 species of flora and fauna. These results include 12 exotic species (Rilov and Galil, 2009), such as the sea hare Bursatella leachii or the polychaeta Branchiomma luctuosum. In addition to the exotic species, we have also found some iconic species like the dusky grouper (Epinepheus marginatus) and the fan mussel (Pinna nobilis), a species in critical condition in Spanish Mediterranean waters. In our study we observed several specimens of $P$. nobilis in six samplings between the $16^{\text {th }}$ of May 2018 and the $9^{\text {th }}$ of February 2019. After the last sighting in February 2019, no one else has been found alive. Together with visual qualitative sampling, a quantitative sampling has been conducted to compare year round changes in biodiversity in two locations (Megina et al., 2016): the concrete vertical walls of the bath area and concrete posts that are in the middle of it. Both are hard artificial substrata where we scraped a standardized surface of $20 \mathrm{~cm} \times 20 \mathrm{~cm}$ using a pickaxe and a club. At each location we collected three samples that were stored in plastic bags. Such sampling for quantitative purposes was made four times on November 2018, and February, May and August 2019. Results confirm that biodiversity is lower in the posts than in the walls (Tyrrell and Byers, 2007), and also decreases in the two locations in summer, when the bryozoan Amathia verticillata covers many surfaces leading to a reduction of algal cover and associated species.
\end{abstract}

Key words: Urban beach, Biodiversity, Exotic species, Forum de Barcelona

Acknowledgments: The authors thank all the people from University of Barcelona who 
collected background information essential to our work, Guillermo Álvarez, Vicepresident of the Catalan Federation of Underwater Activities (FECDAS) for logistic and financial support and for his active participation, Cressi 1946 and EQSI Global Engineering for their financial support, and Saita Diving Center for logistic help with the sampler's air tanks. Thanks are given too the many sampling volunteers of VIMAR Research Group and divers Xavier Salvador, Marc Peralta and Eugeni Canals for sharing with us images of their visual censuses.

\section{References:}

Coll, M., Piroddi, C., Steenbeek, J., Kaschner, K. et al. (2010). The biodiversity of the Mediterranean Sea: estimates, patterns, and threats. PLoS ONE, 5 (8), e11842.

Ferrario, J., Caronni, S., Occhipinti-Ambrogi, A. and Marchini, A. (2017). Role of commercial harbours and recreational marinas in the spread of non-indigenous fouling species. Biofouling, 33, 651-660.

Megina, C., González-Duarte, M.M. and López-González, P.J. (2016). Benthic assemblages, biodiversity and invasiveness in marinas and commercial harbours: an investigation using a bioindicator group. Biofouling, 32, 465-475.

Rilov, G. and Galil, B. (2009). Marine bioinvasions in the Mediterranean Sea - History, distribution and ecology. In G. Rilov G. and J.A. Crooks (eds): Biological invasions in marine ecosystems. Ecological studies (analysis and synthesis), Springer, Berlin, Heidelberg, vol. 204.

Tyrrell, M. and Byers, J. (2007). Do artificial substrates favor nonindigenous fouling species over native species?. Journal of Experimental Marine Biology and Ecology, 342 54-60. 


\title{
PERFORMANCE OF THE COLD-WATER CORAL LOPHELIA PERTUSA UNDER NATURAL THERMAL VARIABILITY
}

\author{
Andrea Gori ${ }^{1}$, Carlos E. Gómez ${ }^{2}$, Alexis Weinnig ${ }^{2}$, Adam Hallaj ${ }^{2}$, Abigail Keller², \\ Erik Cordes ${ }^{2}$ \\ ${ }^{1}$ Departament de Biologia Evolutiva, Ecologia i Ciències Ambientals, \\ Universitat de Barcelona, Barcelona, SPAIN. \\ gori@ub.edu,agori.mail@gmail.com \\ ${ }^{2}$ Department of Biology, Temple University, Philadelphia, USA. \\ c.gomez@temple.edu,tug08093@temple.edu,tuf88114@temple.edu,tuj23083@temple.edu, \\ ecordes@temple.edu
}

\begin{abstract}
Lophelia pertusa is the most widespread cold-water coral forming extensive calcium carbonate structure in the deep-sea, thus creating complex habitat for a variety of associated species (Roberts et al. 2006; Cordes et al. 2008). This species is distributed in cold waters at $6-12^{\circ} \mathrm{C}$, showing an upper thermal limit at $15^{\circ} \mathrm{C}$ (Brooke et al. 2013). A recently discovered large deep-sea coral reef composed by L. pertusa off the coast of South Carolina at $650-700 \mathrm{~m}$ depth is regularly exposed to periodic arrival of warm surface waters (Mienis et al. 2014). The main aim of this study was to understand the physiological response of this cold-water coral species to the observed range of natural variability in temperature. Short-term experiments were performed replicating the environmental maximum $\left(14^{\circ} \mathrm{C}\right)$ and minimum $\left(8^{\circ} \mathrm{C}\right)$ temperature variation in the coral metabolism and feeding. We found $100 \%$ survival in the temperature range tested for the length of the experiment. Nevertheless, temperature had an effect in the metabolic functions by increasing the respiration rates at $14^{\circ} \mathrm{C}$ by $\sim 50 \%$ relative to the ambient temperature of $8^{\circ} \mathrm{C}$. Two-fold decrease in feeding rates at $14^{\circ} \mathrm{C}$ compare to ambient temperature was observed, thus increasing the probability of temperature-induced metabolic stress. These results highlight the sensibility and the importance of temperature variation in the metabolic performance of cold-water corals, particularly in the South-East US, where climate change predictors forecast an increase in the frequency and duration of incursion of surface, warm waters to deeper habitats where L. pertusa grow and form unique structures.
\end{abstract}

Key words: Cold-Water Corals, Thermal Stress, Eco-Physiology

\section{References:}

Brooke, S., Ross, S.W., Bane, J.M., Seim, H.E., Young, C.M. (2013). Temperature tolerance of the deep-sea coral Lophelia pertusa from the southeastern United States. Deep Sea Research II, 92, 240-248.

Cordes, E.E., McGinley, M.P., Podowski, E.L., Becker, E.L., Fisher, C.R. (2008). Coral communities of the Gulf of Mexico. Deep-Sea Research I, 55, 777-787. 
Mienis, F., Duineveld, G.C.A., Davies, A.J., Lavaleye, M.M.S., Ross, S.W., Seim, H., Bane, J., van Haren, H., Bergman, M.J.N., de Haas, H., Brooke, S., van Weering, T.C.E. (2014). Cold-water coral growth under extreme environmental conditions, the Cape Lookout area, NW Atlantic. Biogeosciences, 11, 2543-2560.

Roberts, J.M., Wheeler, A.J., Freiwald, A. (2006). Reefs of the deep: the biology and geology of cold-water coral ecosystems. Science 312, 543-547. 


\title{
SPATIO-TEMPORAL CHANGE OF INDICATORS OF MARINE COMMUNITIES ALONG A LATITUDINAL GRADIENT IN THE WESTERN MEDITERRANEAN SEA
}

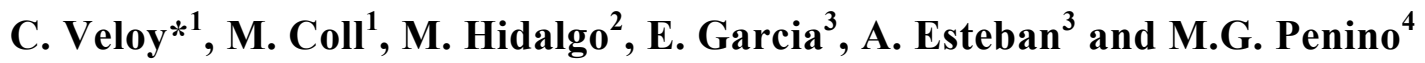 \\ ${ }^{1}$ Institut de Ciències del Mar, Recursos Marinos Renovables, 08003 Barcelona, SPAIN. \\ veloy@icm.csic.es,mcoll@icm.csic.es \\ ${ }^{2}$ Instituto Español de Oceanografía, Centre Oceanográfico de Baleares, Ecosystem Oceanography \\ Group (GRECO), 07015 Palma de Mallorca, SPAIN. \\ jmhidalgo@ieo.es \\ ${ }^{3}$ Instituto Español de Oceanografía, Centro Oceanográfico de Murcia, Ecosistemas marinos \\ explotados - Pesca Murcia, San Pedro del Pinatar, SPAIN. \\ encarnacion.garcia@ieo.es, antonio.esteban@ieo.es \\ ${ }^{4}$ Instituto Español de Oceanografia, Centro Oceanográfico de Vigo, Departamento de Pesquerías, \\ 36390 Vigo, SPAIN. \\ grazia.pennino@ieo.es
}

\begin{abstract}
The Mediterranean Sea is a marine ecosystem with high heterogeneity in its physical, chemical, biological and ecological characteristics, with clear north-south and east-west gradients. It is also an important area in terms of biodiversity and conservation of vulnerable species, as it suffers several human impacts, like fishing and climate change. Previous studies have characterized spatial and temporal patterns of species distribution and biodiversity indicators. However, a community-based analysis combining specific indicators sensitive to fishing impact and climate variability that help to identify which areas and taxa are most sensitive to specific drivers is still missing. In this study, we examined spatio-temporal changes of marine communities along a latitudinal gradient off Spain's mainland in the Western Mediterranean Sea using data from the MEDITS surveys from 1994 to 2017. Several ecological indicators measuring $\alpha$ (richness, Shannon index and Pielou's evenness index) and $\beta$ diversity (assessing both turnover and nestedness) were selected, as well as indicators linked with changes in communities due to fishing impact or climate change, like community biomass and functional groups, relative predator weight and trophic level metrics. We used correlation analyses between these indicators and other variables (among them year, location and subarea) and spatial-temporal statistical models to assess variations in the indicators and spatial-temporal gradients. Our results clearly show a heterogeneous response between taxa and area, with a remarkable increase in several indicators when focusing on cephalopods. Our study shows a contrasting response between taxonomic groups suggesting a change in the ecosystem functioning over time in the Western Mediterranean Sea. This in depth analysis of the ecosystem serves as a case study for the use of selected indicators that combine the capacity to detect changes both at regional and local scales.
\end{abstract}


Key words: Mediterranean Sea, Ecological indicators, Beta diversity, Fishing, Climate change

Acknowledgments: This study has been funded by the European project TRIATLAS (BG-08-2018-2019-RIA-SEP-210482854), predoctoral scholarships of the Spanish Ministry of Science and Universities (FPU18/05594) and the European Maritime and Fisheries Fund (EMFF) within the National Program of collection, management and use of data in the fisheries sector and support for scientific advice regarding the Common Fisheries Policy, that support the MEDITS program. 


\title{
TRAWLING FOOTPRINT AND DIVERSITY OF BENTHIC COMMUNITIES IN THE MENORCA CHANNEL (WESTERN MEDITERRANEAN)
}

\author{
M.T. Farriols* $^{* 1}$, U. Fernandez-Arcaya ${ }^{1}$, F. Ordines ${ }^{1}$, D. Palomino ${ }^{2}$, N.R. De la \\ Ballina $^{1}$, E. Marco-Herrero ${ }^{1}$, N. Martínez-Carreño ${ }^{2}$, J.A. Díaz ${ }^{1}$, S. Mallol ${ }^{1}$, \\ S. Ramírez-Amaro ${ }^{1}$, A. Muñoz ${ }^{1}$, D. Díaz ${ }^{1}$, J.T. Vázquez ${ }^{2}$ and E. Massutí ${ }^{1}$ \\ ${ }^{1}$ Instituto Español de Oceanografía, Centre Oceanogràfic de les Balears, Palma, Spain. \\ mt.farriols@ieo.es,ulla.fernandez@ieo.es,xisco.ordinas@ieo.es,nuria.rodriguez@ieo.es, \\ elena.marco@ieo.es,julio.diaz@ieo.es,sandra.mallol@ieo.es,sergio.ramirez@ieo.es, \\ anabel.mcaballero@ieo.es,david.diaz@ieo.es,enric.massuti@ieo.es \\ ${ }^{2}$ Instituto Español de Oceanografía, Centro Oceanográfico de Málaga, Fuengirola, Spain. \\ desiree.palomino@ieo.es,natalia.martinez@ieo.es,juantomas.vazquez@ieo.es
}

\begin{abstract}
:
It is well known that bottom trawling affects the abiotic (seafloor morphology, sediment resuspension, water turbidity) and biotic components (biodiversity, biomass and production) of habitats. However, comparative studies on the effect of trawling on epibenthic communities of sedimentary bottoms are scarce. One of the objectives of LIFE IP INTEMARES project is to assess the impact of bottom trawling on vulnerable benthic habitats of the circalittoral bottoms of the Menorca Channel (western Mediterranean), designated Site of Community Importance (SCI) within the Natura 2000 network. The present study compares the benthic communities of four areas subjected to different bottom trawl fishing intensity levels (null, intermediate and high). The assignment of fishing effort levels was based on the fishing effort distribution in the area calculated from Vessel Monitoring System (VMS) data. The biological samples were collected from 46 beam trawl stations sampled during a scientific survey on April 2019. In order to detect differences related to the different levels of fishing intensity, we calculated four "traditional" diversity indices (i.e. species richness, Margalef's richness, Pielou's evenness and Shannon's diversity), and the recently developed $N_{90}$ diversity index, which has shown to be useful in the detection of the response of demersal and benthic communities to fishing pressure. Our results show the highest values of all the analyzed indices in the nonimpacted area, suggesting a negative effect of bottom trawling on the benthic communities present in Menorca Channel. However, no clear pattern was observed between different degrees of trawling intensity and diversity values, so other factors such as environmental conditions must be also considered to explain these results.
\end{abstract}


Key words: Diversity, Benthic community, Bottom trawling, Menorca Channel, SCI

Acknowledgments: This research has been developed within the project LIFE IP INTEMARES (LIFE15/IPE/ES/000012). We thank all participants in the survey INTEMARES_CANAL0419, as well as the captain and crew of the R/V Ángeles Alvariño. J.A. Díaz and S. Ramírez-Amaro are supported by predoctoral and postdoctoral contracts, co-funded by the Regional Government of the Balearic Islands and the European Social Fund. 


\title{
ISMS
}

\section{LIFE REMoPaF PROJECT (Recovery of Endangered Mollusc Patella ferruginea)}

\author{
Free Espinosa ${ }^{*}$, Manuel Maestre-Delgado ${ }^{1}$, José Carlos García-Gómez ${ }^{1}$, Natalia \\ García-Estévez $^{2}$, Patricia Fort Santa-María ${ }^{2}$, Carmen Pitarch-Moreno ${ }^{3}$, Juan \\ Manuel Paramio ${ }^{3}$, Mabel Cotaina-Castro ${ }^{3}$
}

(1). Dept. Zoología-Facultad Biología; Univ. Sevilla, Sevilla, SPAIN.

free@us.es(*Presenting author),manumaestre@us.es,jcgarcia@us.es

(2). Ingeniería Especializada Obra Civil e Industrial (ACCIONA), Madrid, SPAIN.

natalia.garcia.estevez@acciona.com,patricia.fort.santamaria@acciona.com

(3). Autoridad Portuaria de Melilla; Melilla, SPAIN.

cpitarch@puertodemelilla.es,jmparamio@puertodemelilla.es,mcotaina@puertodemelilla.es

\begin{abstract}
The European Commission under the LIFE15 program selected LIFE REMoPaF project that is being developed by a consortium leaded by ACCIONA Ingeniería (AI), along with the University of Seville (US) and Port Authority of Melilla (APM).

The project began in 2016 and will run until 2021, being Spain the country where the actions are developed. The project is focused on the repopulation of the ribbed Mediterranean limpet (Patella ferruginea), a species in danger of extinction, through recruitment of small juveniles at the Donor Area (Port of Melilla), where there is currently a large well-preserved population, and subsequent translocation to the Receiving Area, in Algeciras Bay (Port of La Línea) where a low density population can be found. This target is being implemented

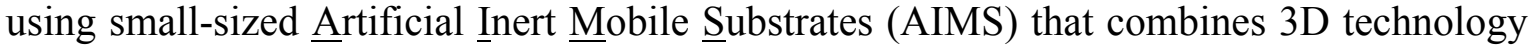
and conventional methods, mimicking the microtopography of the substrata where the larvae recruit.

To date, over 800 AIMS have been installed in the Donor Area. Most of the specimens recruited until now have been moved to the Receiving Area. Two translocations have taken place (October 2018 and October 2019) with a total of $79(31+47)$ specimens in $60(20+40)$ AIMS. Monitoring of the moved specimens has been performed weekly for the first month, monthly during the next four months and finally on a quarterly basis from the sixth month. The survival rate during the transfer has been $100 \%$, for both transfers. During the monitoring period, the survival rates were $81 \%-91.5 \%$ ( $1^{\text {st }}$ month $), 77.5 \%-87 \%\left(2^{\text {nd }}\right.$ month $)$ for the first and second transfers respectively; and $74 \%\left(3^{\text {rd }}\right.$ month $), 68 \%$ ( $4^{\text {th }}$ month $)$ and $45 \%$ ( $1^{\text {st }}$ year $)$ for the first transfer.

Considering both transfers at the same time, two months after the transfer, the survival rate is being higher for juveniles and recruits than for adult specimens (89\% survival of recruits and juveniles vs. $75 \%$ survival of adult specimens).
\end{abstract}

Key words: REMoPaF, LIFE, AIMS, Patella ferruginea. 
Acknowledgments: We would like to acknowledge the co-financing (60\% project's eligible costs) and the support of the European Commission without which it would not be possible to carry out and to progress successfully this project. We would also like to express our special thanks to the APBA (Port Authority of Algeciras Bay) for supporting and providing its facilities in the Port of La Línea as the Receiving Area. And our most sincere gratitude to the Ministry of Environment, the Autonomous City of Melilla, the Regional Government of Andalusia and the City Council of La Línea de la Concepción for their unconditional support to the project.

\section{References:}

MMAMR. (2008). Estrategia para la conservación de la lapa ferrugínea (Patella ferruginea) en España. Ministerio de Medio Ambiente y Medio Rural y Marino, Gobierno de España, 49 pp.

LIFE REMoPaF Project (2017). http://www.liferemopaf.org 


\title{
REPEATABILITY OF BEHAVIOUR IN THE PEARLY RAZORFISH (Xyrichtys novacula): SEX AND BODY SIZE EFFECTS
}

\author{
Júlia Mulet ${ }^{1}$, Martina Martorell-Barceló ${ }^{2}$ and Josep Alós ${ }^{3}$ \\ ${ }^{1,2}$ Fish ecology, IMEDEA, Esporles, SPAIN. \\ julismulet@gmail.com,mmartorell@imedea.uib-csic.es \\ ${ }^{3}$ Fish ecology, IMEDEA, Esporles, SPAIN. \\ alos@imedea.uib-csic.es
}

\begin{abstract}
:
Behavioural types (also known as personality or temperament) are generated by betweenindividual differences in behavioural traits that are consistent over time and ecological contexts. Behavioural types are widespread in nature and play a relevant role in many ecological and evolutionary processes. Here, we have studied for the first time the individual behaviour consistency degree of the pearly razorfish, Xyrichtys novacula, one of the most important species for Mediterranean recreative fisheries. Also, pearly razorfish has a very high commercial value in Balearic Islands. We studied the behaviour consistency degree through the repeatability score $(R)$ : a classical measure defining behavioural types. Behavioural types were quantified along three of the five major axes of fish personality, shyness-boldness, exploration-avoidance and aggressiveness, trough standardized personality tests. The experiments were done under laboratory conditions in semi-natural aquariums, where individuals remained isolated for one week under fully controlled environmental conditions. The study was done with 60 individuals from one of the most important pearly razorfish fisheries in Mallorca island, and we generated independent repeated measures of each behavioural axes. The degree of consistency in the individual behaviour was quantified with the $R$-score. The phenotypic variance decomposition revealed significant $R$ ( 0.54 with a low BCI of 0.48 and upper BCI of 0.61$)$ in aggressiveness behavioral trait, suggesting high predictability of individual behavioral variation and the existence of different behavioral types. We also evaluated the effect of the body size and sex. Our work didn't reveal sex or size dependent differences in personality traits. The study of personality traits is essential to understand the vulnerability of the species to anthropogenic activities such as fishing, to determine population resilience or the understand connectivity patterns between sub-populations. Our work therefore provides novel insight into the ecological and evolutionary consequence of behaviour in exploited fish species.
\end{abstract}

Key words: Personality, behavioural syndrome, repeatability, pearly razorfish, mirror test 


\section{References}

Bell AM, Hankison SJ, Laskowski KL. 2009 The repeatability of behaviour: a meta-analysis. Anim. Behav. 77, 771-783.

Réale D, Reader SM, Sol D, McDougall PT, Dingemanse NJ. 2007 Integrating animal temperament within ecology and evolution. Biol. Rev. 82, 291-318.

Conrad JL, Weinersmith KL, Brodin T, Saltz JB, Sih A. 2011 Behavioural syndromes in fishes: a review with implications for ecology and fisheries management. J. Fish Biol. 78, 395-435. 


\title{
VEGAN NUDIBRANCHS? FEEDING BEHAVIOR OF THE CRYPTIC NUDIBRANCH POLYCERELLA EMERTONI ASSOCIATED WITH THE PSEUDO-INDIGENOUS BRYOZOAN AMATHIA VERTICILLATA
}

\author{
J. Camps-Castellà ${ }^{* 1,2}$, M. Ballesteros ${ }^{3}$, R. Trobajo ${ }^{1}$, M. Pontes ${ }^{4}$ and P. Prado ${ }^{1}$ \\ ${ }^{1}$ Marine and Continental Waters Program, IRTA \\ Sant Carles de la Ràpita, SPAIN. \\ judithcamps@outlook.es,rosa.trobajo@irta.cat,patricia.prado@irta.cat \\ ${ }^{2}$ Programa de Magíster en Ecología Marina, Universidad Católica de la Santísima Concepción, \\ Concepción, CHILE. \\ jcamps@magister.ucsc.cl \\ ${ }^{3}$ Departament de Biologia Evolutiva, Ecologia i Ciències Ambientals, Universitat de Barcelona, \\ Barcelona, SPAIN \\ mballesteros@ub.edu \\ ${ }^{4}$ VIMAR-Vida Marina, Barcelona, SPAIN \\ miquelpontes@gmail.com
}

\begin{abstract}
The feeding behavior of nudibranchs has always been regarded as carnivorous and this group is often referred to as an example of specialized predators. In the Alfacs Bay (Ebro Delta, NW Mediterranean), the small sized, cryptic nudibranch Polycerella emertoni and its egg masses are found associated with the pseudo-indigenous bryozoan Amathia verticillata, which is thought to be its target prey. In this study, we investigate the seasonal abundance of both species in the Alfacs Bay throughout an entire year and we assess the trophic ecology of $P$. emertoni by using a combination of methods including stable isotope analyses coupled with Bayesian mixing models $\left(\delta^{13} \mathrm{C}\right.$ and $\left.\delta^{15} \mathrm{~N}\right)$, examination of stomach contents and video recording of feeding habits. Besides, a morphological analysis of the radula was also conducted in order to investigate a possible relationship with diet type. Our results show that, contrary to expectations, this species is a micro-herbivore feeding on the periphyton covering $A$. verticillata (up to $99 \%$ of the diet, according to mixing models). In particular, a very rich and diverse diatom community was observed on $A$. verticillata and several of the diatom taxa were also found in the stomach contents of $P$. emertoni. Regarding the radula, our results point to a distinctive morphology compared to other nudibranch species also found on $A$. verticillata, but further research is needed to confirm diet in the other taxa. The high seasonal association observed between $P$. emertoni and $A$. verticillata may be attributed to mimicry of habitat attributes or to selective feeding on some microalgae species growing on the bryozoan. Overall, our study highlights the need to reassess the trophic role of many taxa in the order Nudibranchia.
\end{abstract}


Key words: Herbivory, Stable isotopes, Gut contents, Nudibranchs, Diatoms

Acknowledgments: We thank Dr. Argyro Zenetos for her help with some references on the distribution of $P$. emertoni from the 'gray' literature and to Maria Casso and collaborators for passing us the database of their research and thus be able to analyze the results of abundance pattern of the bryozoan $A$. verticillata over the years. Also, we thank the IRTA institution for providing the facilities and the materials necessaries for conducting the study. Finally, we are grateful to the boat skippers Pep Cabanes and José Luis Costa for their valuable help. This work has benefited from the research funds granted by the Catalan Government for the consolidate research group in Biology and Ecology of Benthos (BEB) (SGR2017-1120) of the University of Barcelona to which one of the authors belongs. 


\title{
IMPLEMENTATION OF THE OBSEA COASTAL SEAFLOOR OBSERVATORY TO DERIVE ECOLOGICAL INDICATORS
}

\author{
M. Francescangeli ${ }^{1}$, J. Del Rio ${ }^{1}$, M. Nogueras ${ }^{1}$, D. Chatzievangelou $^{2}$, S. Marini ${ }^{3}$ and J. \\ $\operatorname{Aguzzi}^{4}$ \\ ${ }^{1}$ SARTI Research Group, Electronics Department (Universitat Politècnica de Catalunya; UPC), \\ 08800 Vilanova i la Geltrú-Barcelona, SPAIN. \\ marco.francescangeli@upc.edu, joaquin.del.rio@upc.edu,marc.nogueras@upc.edu \\ ${ }^{2}$ Jacobs University, 28759 Bremen, GERMANY. \\ damchatzi@gmail.com \\ ${ }^{3}$ National Research Council of Italy, Institute of Marine Sciences, Forte Santa Teresa, 19032 La \\ Spezia, ITALY. \\ simone.marini@sp.ismar.cnr.it \\ ${ }^{4}$ Instituto de Ciencias del Mar (ICM-CSIC), 08003 Barcelona, SPAIN. \\ jaguzzi@icm.csic.es
}

\begin{abstract}
Reliable biodiversity and ecosystem functioning assessment can be achieved through the development and implementation of new cabled seafloor observatories. Those multiparametric video-platforms have the capability to achieve continuous, high-frequency and long-lasting monitoring of marine ecosystems (Aguzzi et al., 2019; Danovaro et al., 2017). In this framework, the OBSEA (www.obsea.es) was deployed at $20 \mathrm{~m}$ depth in 2009, $4 \mathrm{~km}$ off of Vilanova i la Gertrú (Barcelona). Since 2009, a 30 min time-lapse image acquisition focused on the bony fish community composed by 25 species and 2 genres (Aguzzi et al., 2015), as highly motile species considered good indicators for climate change (Duvly et al., 2008). This has been accompanied by environmental data collection (Aguzzi et al. 2011). The described asset is now being upgraded with the implementation of an additional satellite tripod camera and an Internet Operated Vehicle (IOV), a crawler, to increase the video spatial coverage. The existing imaging and environmental data set, reaching a length of nearly a decade, will be now complemented by the new spatiallyextended one, in order to test the ecological representation power of still and mobile cameras and to derive ecological indicators (i.e. density of populations, richness and relative abundance as evenness) at diel, monthly, seasonal and inter-annual scales. Moreover, inferences of potential cause-and-effects principles between environmental variables and species responses (i.e. expressed as fluctuations in counts) will be evaluated to identify putative drivers controlling their behaviour. To date we are observing marked diel counts fluctuations for all fish species. This tendency is maintained throughout the seasons with the amplitude of the total fish counts curve following the variation in the photophase length amplitude, described through the sun irradiance.
\end{abstract}

Key words: Seafloor observatories, OBSEA, Fish community, Climate change, Ecological indicators 
Acknowledgments: The main author wants to acknowledge his FPI grant from the Spanish Ministry of Science and Innovation founded by the European Social Found (ref. TEC2017-87861-R). This work is partially funded the Spanish Ministry of Education and

Science (MEC) with the project "Redes de sensores submarinos autónomos y cableados aplicados a la monitorización remota de indicadores biológicos" TEC2017-87861-R and by Generalitat de Catalunya "Sistemas de Adquisición Remota de datos y Tratamiento de la Información en el Medio Marino" (SARTI-MAR)" 2017 SGR 371. Researchers want to acknowledge the support of the Associated Unit Tecnoterra composed by members of Universidad Politécnica de Cataluña (UPC) and the Consejo Superior de Investigaciones Científicas (CSIC). This work used the EGI infrastructure with the dedicated support of INFN-CATANIA-STACK and data derived from 'estacions meteorològiques automàtiques de la xarxa d'estacions de Catalunya (XEMA), Meteocat.

\section{References:}

Aguzzi, J., Chatzievangelou, D., Marini, S., Fanelli, E., Danovaro, R., Flögel, S., Lebris, N., Juanes, F., De Leo, F., Del Rio, J., Thomsen, L., Costa, C., Riccobene, G., Tamburini, C., Lefevre, D., Gojak, C., Poulain, P.M., Favali, P., Griffa, A., Purser, A., Cline, D., Edigington, D., Navarro, J., Stefanni, S., D'Hondt, S., Pride, I.G., Rountree, R. and Company, J.B. (2019). New high-tech interactive and flexible networks for the future monitoring of deep-sea ecosystems. Environmental Science and Technology, 53, 6616-6631.

Aguzzi, J., Doya, C., Tecchio, S., De Leo, F.C., Azzurro, E., Costa, C., Sbragaglia, V., Del Río, J., Navarro, J., Ruhl, H.A., Company, J.B., Favali, P., Purser, A., Thomsen, L., and Catalán, I.A. (2015). Coastal observatories for monitoring of fish behaviour and their responses to environmental changes. Reviews in fish biology and fisheries, 25(3), 463-483.

Aguzzi, J., Mànuel, A., Condal, F., Guillén, J., Nogueras, M., del Rio, J., Costa, C., Menesatti, P., Puig, P., Sardà, F., Toma, D. and Palanques, A. (2011). The new seafloor observatory (OBSEA) for remote and long-term coastal ecosystem monitoring. Sensors, 11, 5850-5872.

Danovaro, R., Aguzzi, J., Fanelli, E., Billet, D. Gjerde, K., Jamieson, A., Ramirez-Llodra, E., Smith, C.R., Snelgrove, P.V.R., Thomsen, L. and Van Dover, C. (2017). A new international ecosystem-based strategy for the global deep ocean. Science, 355, 452-454.

Duvly, N.K., Rogers, S.I., Jennings, S., Stelzenmüller, V., Dye, S.R. and Skjoldal, H. R. (2008). Climate change and deepening of the North Sea fish assemblage: a biotic indicator of warming seas. Journal of Applied Ecology, 45, 1029-1039. 


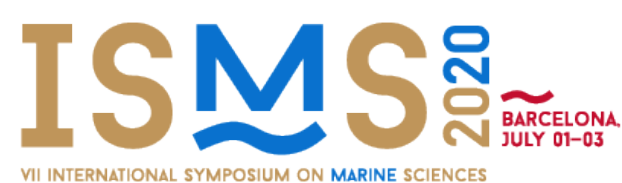

VII International Symposium on Marine Sciences

ISMS 2020

Barcelona (Spain), $1^{\text {st }}-3^{\text {rd }}$ July 2020

\section{AGE AND GROWTH INDICATE THAT THE REMAINING Pinna nobilis POPULATIONS LIVING IN SPAIN ARE HIGHLY THREATENED AND VULNERABLE}

\author{
S. Hernandis ${ }^{* 1,2}$, J.R. García-March ${ }^{1}$, M. Vázquez-Luis ${ }^{3}$, P. Prado ${ }^{4}$, S. Deudero ${ }^{3}$, \\ N. Vicente $^{5,6}$, J. Torres ${ }^{1}$, T. Añon ${ }^{1}$, J. Bernal ${ }^{7}$, A. Ortega ${ }^{7}$, and J. Tena-Medialdea ${ }^{1}$ \\ ${ }^{1}$ Instituto de Investigación en Medio Ambiente y Ciencia Marina (IMEDMAR-UCV), Universidad \\ Católica de Valencia SVM, 03710 Calpe, Alicante, SPAIN. \\ sebastia.hernandis@ucv.es,jr.garcia@ucv.es, javier.torres@ucv.es, t_herbella@hotmail.com, \\ josetena@ucv.es \\ ${ }^{2}$ Escuela de Doctorado, Universidad Católica de Valencia San Vicente Mártir, SPAIN. \\ ${ }^{3}$ Instituto Español de Oceanografía (IEO), Centro Oceanográfico de Baleares, 07015 Palma de \\ Mallorca, SPAIN. \\ maite.vazquez@ieo.es, salud.deudero@ieo.es \\ ${ }^{4}$ IRTA-Aquatic Ecosystems, 43540 Sant Carles de la Ràpita, Tarragona, SPAIN. \\ patricia.prado@irta.cat \\ ${ }^{5}$ Institut Océanographique Paul Ricard, Ile des Embiez, 83140 Six Fours les Plages, FRANCE. \\ vnardo3@gmail.com \\ ${ }^{6}$ Institut Mediterranéen de la Biodiversité et de l'Écologie marine et continentale (IMBE), Aix- \\ Marseille Université, FRANCE. \\ ${ }^{7}$ Instituto Español de Oceanografía (IEO), Centro Oceanográfico de Murcia, 30860 Murcia, \\ SPAIN. \\ jaimebernal@hotmail.com,aurelio.ortega@ieo.es
}

\begin{abstract}
A comparative growth study of the fan mussel (Pinna nobilis) has been conducted in 13 populations living in different environments in the western Mediterranean Sea (France and Spain). Two hundred twenty-nine shells (between 8-20 shells of each population) were processed and used to obtain growth records from the posterior adductor muscle scar (PAMS). Size-at-age data were fitted to the Von Bertalanffy growth model using non-linear mixed effects and considering $\mathrm{L}_{\infty}$ (maximum theoretical size of the population) as fixed and $\mathrm{k}$ (the speed at which the asymptotic size is reached) and $\mathrm{t}_{0}$ (the point in time when an individual has zero length as random parameters). The results show that the only two fan mussel populations remaining in Spain (Ebro Delta and Mar Menor) and Diana lagoon in France, which live in an estuary and a coastal lagoon, occupy habitats that are optimal for fast growth, but individuals show low longevity (maximum of 9 years in Mar Menor and 15 in Ebro Delta), complicating the long-term conservation of the species. The lower $\mathrm{L}_{\infty}$ was detected in populations exposed to hydrodynamics (exposed open-sea) whereas the higher $\mathrm{L}_{\infty}$ occurred in the population inhabiting the estuary. Maximum growth rate occurred in lagoons and the estuary whereas the minimum growth rate occurred in exposed open-sea populations. Younger populations were observed in lagoons, the estuary and exposed open-
\end{abstract}


sea populations while the maximum ages were detected in sheltered open-sea and protected marine areas. Multivariate analyses groups the populations into three groups (SO, EO and LG), and a general growth model is proposed for each group; the model can be used as an approximation to calculate the ages of individuals living in similar environments.

Key words: Fan mussel, Von Bertalanffy, Growth model, Conservation 


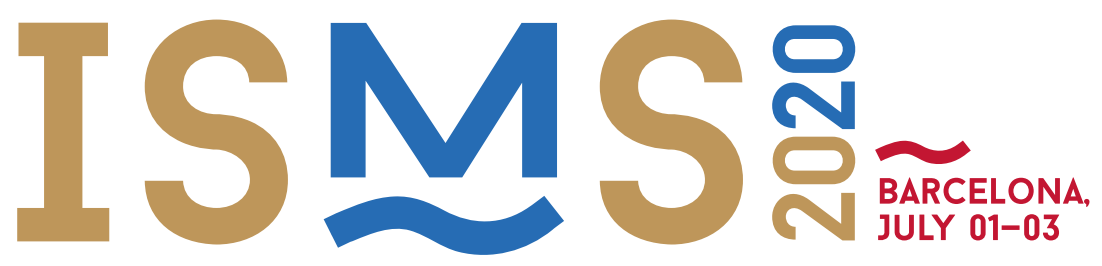

VII INTERNATIONAL SYMPOSIUM ON MARINE SCIENCES BARCELONA
JULY 01-03

ORAL COMMUNICATIONS

MARINE ECOSYSTEMS 


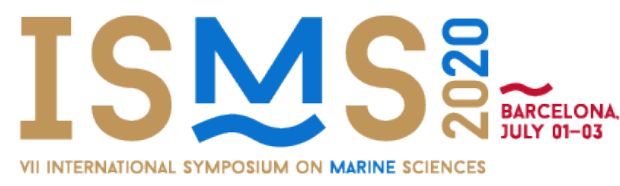

\section{ANALYSIS OF THE SEDIMENT ASSOCIATED WITH POSIDONIA OCEANICA'S WRACK ON THE COAST OF ALICANTE (WESTERN MEDITERRANEAN).}

\author{
Fuster Alonso, Alba*¹, Martínez Vidal, Joaquín² and Corbí Sevila, Hugo ${ }^{3}$ \\ ${ }^{1,2}$ Instituto de Ecología Litoral, Alicante, Spain. \\ alba.fuster1398@gmail.com,j.martinez@ecologialitoral.com \\ 3 Universidad de Alicante, Alicante, Spain. \\ hugo.corbi@gmail.com
}

\begin{abstract}
The Mediterranean coasts are covered with large patches of warck, produced by the effect of waves, storms and heavy swells, which are becoming more and more frequent due to the current climate change scenario, intensifying the transport of vegetable remains to the beaches, including the Alicante's coastline. In fact, Wrack are a system at the marineterrestrial interface, which have hardly been studied, despite the significant ecological consequences (Orr et al., 2005). The wrack in Alicante province's beaches is mainly formed by the marine phanerogam Posidonia oceanica (L.) Delile, endemic to the Mediterranean Sea. However, other phanerogams such as Cymodocea nodosa can also be found in Mediterranean beaches. Due to the refusal of the tourism sector and the surrounding communities to let vegetal remains accumulate on the beaches, the beaches grooming is done throughout the year by means of cleaning operations with heavy machinery (Triviño and Guillén, 2016). The collected wrack are mostly deposited in landfills with no possibility of return to the coast (Guillén et al.,2014). The principal problem linked to the wrack cleared away from the shore is the gradual loss of sediment associated with its permanent removal from the system, causing the regression of the beaches' surfaces and volumes (Roing-Munar et al., 2019). Therefore, this study analyses

the sediments related to the natural warck and the accumulations, created by the corresponding machinery, on four beaches, three of which belong to El Campello and one of which to Santa Pola. Indeed, significant differences are shown between the sediment hosted in natural wrack and the accumulations generated by humans, in the different beaches, caused by the sedimentary discrepancies among the beaches. Nevertheless, it can be highlighted that the average percentage of sediment in weight contained in natural wrack on all the investigated beaches was $60,16 \%$ and the accumulations generated by humans showed $89,11 \%$ of sediment in weight.
\end{abstract}

Key words: wrack, Posidonia oceanica, beach grooming, sediments. 


\section{Acknowledgments:}

The authors are grateful to Instituto de Ecología Litoral for providing the installations and materials necessary to carry out the work, as well as for the opportunity given to us. Likewise, thanks to the University of Alicante for the support provided and the use of their facilities. Together, both institutions, through their workers, have provided recommendations and critical comments that prove the quality of the work.

\section{References:}

1. Guillén, J., Martínez-Vidal, J., Triviño, A., Soler, G., Fages, E., Torre, K., et al., 2014. Guía de buenas prácticas para la gestión, recogida y tratamiento de los arribazones de algas y plantas marinas en las costas. Proyecto Seamatter LIFE11 ENV/ES/000600. Ed. Instituto de Ecología Litoral, El Campello, 24 pp.

2. Orr, M., Zimmer, M., Jelinski, D. E., \& Mews, M. (2005). Wrack deposition on different beach types: spatial and temporal variation in the pattern of subsidy. Ecology, 86(6), 1496-1507.

3. Roig-Munar, F.X., Rodríguez-Perea, A., Martín-Prieto, J.Á., Gelabert Ferrer, B., 2019. Cuantificación de la pérdida de sedimento por la retirada mecánica de bermas (banquettes) de Posidonia oceanica en las playas de las islas Baleares: consecuencias geomorfológicas. Revista de la Sociedad Geológica de España, 32 (2): en prensa.

4. Triviño, A., Soler, G., \& Guillén, J. E. (2016). Children perception of wrack-covered beaches and beach grooming in SE Spain. In Frontiers in Marine Science. Conference Abstract: XIX Iberian Symposium on Marine Biology Studies. 


\title{
MAPPING AND MONITORING OF A TREPTACANTHA BARBATA RESTORED POPULATION IN MENORCA
}

\author{
A. Gran* ${ }^{1,2}$, J. Movilla*2, T. Quetglas ${ }^{3}$, C. Galobart ${ }^{4}$, I. Bolado ${ }^{2}$ and M.E. Cefali ${ }^{* 2}$ \\ ${ }^{1}$ Departamento de Biología, Universidad de las Islas Baleares (UIB), Palma de Mallorca, SPAIN. \\ aliciagrangarcia@gmail.com \\ ${ }^{2}$ Estación de Investigación “Jaume Ferrer”, Instituto Español de Oceanografía (IEO), La Mola \\ (Menorca), SPAIN. \\ juancho.movilla@ieo.es,ignacio.bolado@ieo.es,malen.cefali@ieo.es \\ ${ }^{3}$ Centro Oceanográfico de Baleares, Instituto Español de Oceanografía (IEO), Palma de Mallorca, \\ SPAIN. \\ toni.quetglas@ieo.es \\ ${ }^{4}$ Centro de Estudios Avanzados de Blanes (CEAB-CSIC), Blanes (Girona), SPAIN. \\ cgalobart@ceab.csic.es
}

\begin{abstract}
Macroalgae of the genus Cystoseira sensu lato have morphological characteristics and long-life spans that make them bioengineering species, capable of forming structurally complex habitats that harbour high biodiversity. In recent decades, some of these species have experienced a severe decline in the Mediterranean Sea. Therefore, it has been necessary to implement management and protection measures addressed to facilitate the re-establishment and the continuation of their populations. Moreover, given the vulnerability of these species to any natural or anthropogenic disturbance, long-term monitoring is crucial to evaluate their conservation state and to understand their response to such changes. The main objective of the present study is to assess the current state of a population of the protected species Treptacantha barbata (formerly Cystoseira barbata) (see Orellana et al., 2019), which was restored in Cala Teulera (Mahón Bay, Menorca) in 2011. In order to accomplish this purpose, we developed an exhaustive cartography, recording the spatial distribution and coverage rate of the target species almost ten years after the restoration project. In addition, we determined its maturity state by comparing the size-class structure of the restored population with three reference ones located in Fornells Bay (north coast of Menorca) over the last three years. The restored population exhibits a progressive dispersal pattern from the initial restoration zone, with new individuals especially colonizing the surrounding area at the shallowest level as a continuous belt. According to the present size-class structure, the restored population of $T$. barbata can be considered as mature and well established when compared to reference populations. This study allowed us to describe post-restoration growth patterns, and the spatial and temporal evolution of a habitatforming species. Furthermore, it emphasizes the necessity of long-term monitoring to clarify and deepen knowledge about the biotic and abiotic interactions of this species, as well as their reproductive patterns.
\end{abstract}


Key words: Cartography, Treptacantha barbata, Restoration, Spatial distribution, Size structure

Acknowledgments: This project was carried out as a result of the collaboration agreement between the Instituto Español de Oceanografía (IEO) and the Govern de les Illes Balears, which allows the implementation and development of the Estación de Investigación Jaume Ferrer, and was co-funded by the Programa Operativo del Fondo Europeo de Desarrollo Regional (FEDER).

\section{References:}

Cefalì, M. E., Movilla, J., Bolado, I., Mallol, S. and Deudero, S. (2017). Actividades científico-técnicas realizadas en la Estación Jaume Ferrer de La Mola de Menorca. Informe Técnico 2017.

Cefalì, M. E., Movilla, J., Bolado, I., Mallol, S., Reñones, O., Díaz, D., Guijarro, B., Muñoz, A., Compa, M., and Deudero, S. (2018). Actividades científico-técnicas realizadas en la Estación Jaume Ferrer de La Mola de Menorca. Informe Técnico 2018.

Massutí, E., Sales, M., Reñones, O., Cuadros, A., Vidal, E. M., Sintes, J., Morrillas, A. and Oliver, P. (2015). Convenio de colaboración para la puesta en marcha y el desarrollo científico de la Estación de Investigación "Jaume Ferrer" (La Mola, Menorca). Informe Final 2010-2015.

Verdura, J., Sales, M., Ballesteros, E., Cefalì, M. E. and Cebrian, E. (2018). Restoration of a canopy-forming alga based on recruitment enhancement: Methods and long-term success assessment. Frontiers in Plant Science, 9, 1832. 


\title{
MAPPING INVASIVE MACROALGAE IN NW IBERIAN PENINSULA
}

\author{
Blanco Andreu ${ }^{1,2}$, Larrinaga Asier R. ${ }^{3,4}$, Troncoso Jesus ${ }^{1,2}$, Lemos Marco F.L. ${ }^{5}$, \\ Olabarria Celia ${ }^{1,2}$ \\ ${ }^{1}$ Centro de Investigación Mariña da Universidade de Vigo (CIM-UVigo), Illa de \\ Toralla s/n, 36331 Vigo, Spain \\ ${ }^{2}$ Departamento de Ecoloxía e Bioloxía Animal, Universidade de Vigo, Campus As \\ Lagoas-Marcosende, 36310 Vigo, Spain \\ anblanco@uvigo.gal \\ colabarria@uvigo.es \\ troncoso@uvigo.es \\ ${ }^{3} \mathrm{eNeBaDa}$, Calle Ponte do Sar, 43C-1F, 15702 Santiago de Compostela, A Coruña, \\ Spain \\ ${ }^{4}$ Grupo de Estudo do Medio Mariño (GEMM), Porto deportivo s/n, Santa Uxía de \\ Riveira, A Coruña, Spain. \\ asierrl@gmail.com
}

${ }^{5}$ MARE - Marine and Environmental Sciences Centre, ESTM, Instituto Politécnico de Leiria, Peniche, Portugal

marco.lemos@ipleiria.pt

\begin{abstract}
In Europe, over $41 \%$ of marine invasive species of Union concern are macroalgae (EASIN 2019). From those, some are well-established along the north-western coast of the Iberian Peninsula and include Grateloupia turuturu Yamada 1941, Asparagopsis armata Harvey 1855 (Rhodophyta), Colpomenia peregrina Sauvageau 1927, Sargassum muticum (Yendo) Fensholt 1955, Undaria pinnatifida (Harvey) Suringar 1873 (Ochrophyta, Phaeophyceae) and Codium fragile ssp. fragile (Suringar) Hariot 1889 (hereafter C. fragile) (Chlorophyta). However, invasive macroalgae have been traditionally poorly managed and this has led to important deleterious effects on native communities, which are already in regression (Martínez et al. 2015). In order to apply effective management actions, it is essential to have a distribution map and information of the factors driving their occurrence. Yet, this information is lacking for invasive macroalgae in
\end{abstract}


the NW Iberian Peninsula. Hence, this study aims to map the current distribution of the invasive macroalgae mentioned above. To do so, an extensive field survey along the coast of Northwestern Iberian Peninsula was carried out. Then, based on presence-absence data and a wide range of biotic, abiotic and anthropogenic predictor variables, correlative species distribution models (SDMs) were used to map their distribution along the study region. The southern Galician rias were pointed as the main hotspot of macroalgal invasion with high probability of occurrence for most of the studied species. Conversely, probability of presence on the Portuguese coast was in general low. Hence, in Portugal early detection should be focused of management actions, especially for $C$. fragile which was not recorded at this region. The high influence of anthropogenic factors suggests that the distribution of the target is still highly dependent on human activity. Therefore, control and surveillance are encouraged in ports and highly dense populated areas, especially in the southern Galician rias. These results are a first step towards a proper management of invasive macroalgae in the NW Iberian Peninsula.

Key words: invasive species management, mapping invasive macroalgae, species distribution modelling, human-stressors

\section{Acknowledgments:}

This work was supported by the European Union through EASME Blue Labs project AMALIA-Algae-to-MArket Lab IdeAs (EASME/EMFF/2016/1.2.1.4/03/SI2.750419). Authors would also like to acknowledge the Consellería de Educación e Ordenación Universitaria Xunta de Galicia (Galician Regional Government), cofunding from the European Regional Development Fund (ERDF), in the framework of the Operational Program Galicia 2014-2020 "A way to build Europe".

\section{References:}

EASIN, 2019. European Commission - Joint Research Centre - European Alien Species Information Network (EASIN) https://easin.jrc.ec.europa.eu/ [online].

Martínez, B., Afonso-Carrillo, J., Anadón, R., Araújo, R., Arenas, F., Arrontes, J., Bárbara, I., Borja, A., Díez, I., Duarte, L., Fernández, C., García Tasende, M., Gorostiaga, J.M., Juanes, J.A., Peteiro, C., Puente, A., Rico, J.M., Sangil, C., Sansón, M., Tuya, F., and Viejo, R.M., 2015. Regresión de las algas marinas en las Islas Canarias y en la costa atlántica de la Península Ibérica por efecto del cambio climático. ALGAS, Boletín Informativo de la Sociedad Española de Ficología, 49, 5-12. 


\title{
LONG TERM MONITORING OF POSIDONIA OCEANICA MEADOWS IN ALICANTE (SE SPAIN): THE IMPORTANCE OF VOLUNTEERING
}

\author{
Blanco-Murillo F.*1, Martínez-Vidal, J. ² Jiménez-Gutierrez, S. 3 ; Guillén-Nieto, \\ J.E. ${ }^{4}$, Sánchez-Lizaso J. L. ${ }^{5}$ \\ ${ }^{1,5}$ Department of Marine Sciences and Applied Biology, University of Alicante, Alicante, SPAIN. \\ fabio.blanco@ua.es,jl.sanchez@ua.es \\ $2,3,4$ Instituto de Ecología Litoral, El Campello, SPAIN \\ j.martinez@ecologialitoral.com,s.jimenez@ecologialitoral.com,j.guillen@ecologialitoral.com
}

\begin{abstract}
:
Posidonia oceanica meadows monitoring is essential to assess the evolution of this priority Mediterranean habitat. To this end, the POSIMED project was created with the aim of studying the state of these ecosystems and involve citizenship through volunteering. 20 years of data from 14 stations at two depths along Alicante coast were analysed. The objective of this work was to analyse temporal trends in shoot density and covering at each station. Moreover, the increase of data quality with time was estimated since part of the volunteers has remained the same for all the period.

Results showed a general positive trend for both metrics, meaning that there is no evidence of a global regression despite of declining in some station due to local impacts. This trend was statistically significant for both shallow and deep stations in the case of density measures.

For covering, the variability of data significantly decreases with time which may be related with the higher expertise of volunteers, but this trend was not observed for density estimates.

Long data series are necessary when studying the dynamics of slow-growing species and to this end, the involvement of volunteers in monitoring may be a useful tool. Our results are consistent with other studies that indicate a reversing trend in the regression of $P$. oceanica meadows in the Mediterranean (Guillen et al, 2013, de los Santos et al, 2019)
\end{abstract}

Key words: Posidonia oceanica, Environmental monitoring, volunteering, long term evolution, seagrass.

Acknowledgments: We wish to thank all volunteers who had participated in the POSIMED project for the last 20 years.

\section{References:}

Guillén, J.E., Sánchez Lizaso, J.L., Jiménez, S., Martínez, J., Codina, A., Montero, M., Triviño, A., Soler, G. and Zubcoff, J.J. (2013). Evolution of Posidonia oceanica seagrass meadows and its implications for management. Journal of Sea Research, 83, 65-71.

de los Santos, C. B., Krause-Jensen, D., Alcoverro, T., Marbà, N., Duarte, C. M., van Katwijk, M. M., Pérez, M., Romero, J., Sánchez-Lizaso, J. L., Roca, G., Jankowska, E., Pérez-Lloréns, J. L., Fournier, J., 
Montefalcone, M., Pergent, G., Ruiz, J. M., Cabaço, S., Cook, K., Wilkes, R. J., ... Santos, R. (2019).

Recent trend reversal for declining European seagrass meadows. Nature Communications, 10 (1), 1-8. 


\title{
MARINE PRODUCTION SPIKES OWING TO HEAVY STORM GLORIA IN A NW MEDITERRANEAN COASTAL SITE WITH A DECREASING CHLOROPHYLL TREND
}

\author{
Francesc Peters* ${ }^{*}$, Laura Arín ${ }^{1}$, Lluïsa $\operatorname{Cros}^{1}$ and M. Monsterrat Sala ${ }^{1}$ \\ ${ }^{1}$ Institut de Ciències del Mar (CSIC), Barcelona, Catalunya, SPAIN. \\ cesc@icm.csic.es,larin@icm.csic.es,lluisa@icm.csic.es,msala@icm.csic.es
}

\begin{abstract}
Phytoplankton production is largely determined by the availability of nutrients. In the open ocean, nutrient availability is largely determined by the mechanical energy needed to bring nutrient-rich deep water mixed with upper ocean surface water, marking a clear seasonal cycle, at least in temperate and subtropical seas. As the surface waters increase their temperature with climate change, stratification becomes stronger and mixing is reduced, theoretically reducing phytoplankton production. In the coastal ocean, terrestrial sources of nutrients, with their own dynamics, blur the seasonal cycle to varying degrees depending on the importance of these sources. Riverine sources, with discharge dynamics heavily modified by water use, especially around large urban areas, may alter the plankton community composition in coastal waters. Heavy storms, such as GLORIA of January 2020, significantly affects such dynamics and cause marine production spikes. Other sources of nutrients, such as atmospheric deposition, are increasingly being recognized as important, especially in the desertification scenario of the Mediterranean area (Sahara dust), but also owing to anthropogenic aerosols in an increasingly industrialized area. We will make extensive use of time series analysis of both satellite data and coastal in-situ monitoring stations to derive both seasonal signal alterations as well as long term changes, especially in chlorophyll data, and discern between open water (mostly climate related) and coastal tendencies. We will estimate the effect of heavy storms on the annual production bugdet taking into account that chlorophyll concentration shows a decreasing tendency, especially in the last few years.
\end{abstract}

Key words: Marine production, Nutrients, GLORIA storm, chlorophyll, long-term trends

Acknowledgments: We thank Ginebra Domènech, Laura Carrillo, Pau Fornós and Estela Romero for previous contributions related to this study. Support provided by ANIMA, a research project of the Spanish Ministry of Economy and Competitiveness (CTM201565720-R). 


\title{
STUDY OF THE REPRODUCTIVE ECOLOGY OF SPICARA SMARIS IN IBIZA ISLAND
}

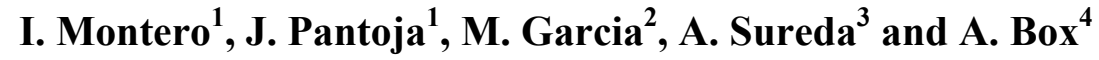 \\ ${ }^{1}$ LEADER group, Ibiza, SPAIN. \\ imontero@conselldeivissa.es,jpantoja@conselldeivissa.es \\ ${ }^{2}$ Biotechnology Department, University of Alicante, Alicante, SPAIN. \\ m.garcia@ua.es \\ ${ }^{3}$ Research Group on Community Nutrition and Oxidative Stress (NUCOX), Department of \\ Fundamental Biology and Health Sciences and CIBEROBN, University of the Balearic Islands, \\ Palma de Mallorca, SPAIN. \\ antoni.sureda@uib.es \\ ${ }^{4}$ Departament de Medi Ambient, Medi Rural i Marí, Consell d'Eivissa, Ibiza, SPAIN. \\ tonibox@conselldeivissa.es
}

\begin{abstract}
Knowledge of the gonadal development of a species can provide complementary information to understand its life cycle. In the case of Spicara smaris the individuals have a protogyne reproduction, so they are first female and after male. Another important characteristic of this species is that individuals stay near the coast during winter to feed and then, when temperature increases, they move to deeper areas to nest. The results of this study show that specimens reach sexual maturity when they are about $11 \pm 0.5 \mathrm{~cm}$ in size, and also that sexual inversion takes place at a size of about $15 \pm 0.5 \mathrm{~cm}$. Using quantifiable indexes such as the gonadosomatic index IGS, and the gonadal index IG, provided numerical values on gonadal development. To describe reproductive structures we used observational indexes, both macroscopic and microscopic. In conclusion, S. smaris development starts at the beginning of winter and reaches its maximum in between March and May.
\end{abstract}

Key words: Development, Gonad, Gonadal indexes, Reproduction

Acknowledgments: We appreciate the participation of the local Action Group of Ibiza and Formentera (LEADER), which financed this research. We also thank Consell d'Eivissa for facilitating this study, and the University of Alicante. 


\title{
CHANGES IN THE POPULATION STRUCTURE OF Callinectes sapidus RATHBUN 1896 IN DIFFERENT INTERCONNECTED COASTAL HABITATS OF SE PENINSULA IBERICA (WESTERN MEDITERRANEAN)
}

\author{
I. Esteso Perona ${ }^{* 1}$, A.A. Ramos-Esplá ${ }^{1,2}$ and C. Barberá Cebrián ${ }^{1,2}$ \\ ${ }^{1,}$ Marine research centre of Santa Pola (CIMAR), University of Alicante, Santa Pola, SPAIN. \\ isabel.esteso@ua.es, \\ ${ }^{2}$ Department of Marine Science and Applied Biology, University of Alicante, Alicante, SPAIN. \\ alfonso.ramos@ua.es,carmen.barbera@ua.es
}

\begin{abstract}
The American blue crab, Callinectes sapidus Rathbun (1896), a species native to the western Atlantic coast, after its introduction into the Mediterranean, has been expanding and establishing populations in different parts and is currently considered an invasive species. The main objective of this study was to know the spatial distribution and population structure of the crab in different interconnected coastal habitats the Southeast of the Iberian Peninsula. The study area focuses mainly in the populations of coastal wetland of the "Salinas de Santa Pola" and "Hondo de Elche" Natural Parks, complementing it with fishing data at the adjacent marine area in the mouth of the Segura River in Guardamar (Alicante). Demographic information on the species was obtained from field surveys and some experimental fisheries with professional fishermen.
\end{abstract}

The data showed a potential migration pattern of the different demographic categories of the crab among the different coastal habitats. In the lagoon environment there have been more catches during the summer months, with more males than females and a large number of juveniles in the fall. In the marine environment, the captures usually start from May and last until November with a high proportion of females. Between the months of June to October, the females are gravid and have different color of the eggs (yellowbrown-black) depending on the state of maturation.

Regarding experimental fishing in the sea, and given the low number of catches and the limitations of the traps, the results have been interpreted with caution, although they coincide with the existing biological information of this species in its natural range. In view of the problems that currently exist with this species in the fishing sector; they have proposed a series of recommendations to monitoring the species and to consider their viability as a fishing resource.

Key words: Blue crab, invasive species, coastal lagoons, fishing.

Acknowledgments: To the personnel of the Natural Parks of the Salinas of Santa Pola and Hondo de Elche, and to the fishermens of Guardamar (Alicante) for their important collaboration. 


\title{
POTENTIAL VULNERABILITY OF DEMERSAL FISHERIES TO WESTERN MEDITERRANEAN WARMING
}

\author{
J. Tomàs-Ferrer*1,2, M. Sanz-Martín ${ }^{1}$, G. Jordà ${ }^{1}$, M. P. Tugores ${ }^{1}$ and E. Massutí $^{1}$ \\ ${ }^{1}$ Instituto Español de Oceanografía - Centre Oceanogràfic de Balears, Palma, Mallorca, SPAIN. \\ joaquim.tomas@uib.cat,marina.sanz@ieo.es,gabriel.jorda@ieo.es,pilar.tugores@ieo.es, \\ enric.massuti@ieo.es \\ ${ }^{2}$ Universitat de les Illes Balears, Palma, Mallorca, SPAIN.
}

\begin{abstract}
The Western Mediterranean Sea is amidst of a warming process, at least since mid XX Century. Moreover, climate simulations point to an accelerated warming at all depths for the next decades. The effects of sea warming on demersal and benthopelagic species of high commercial interest (e.g. Aristaeomorpha foliacea, Loligo vulgaris, Merluccius merluccius, Mullus surmuletus, Parapenaeus longirostris and Solea solea, among other species) are of paramount relevance for the management of their fisheries. Unfortunately, the answer is not simple as it involves a complex chain of interactions between environmental conditions and the different trophic levels. A first limitation is the lack of knowledge on the thermal tolerance of these species, which prevents assessing the direct impact of warming on individuals.

The aim of this study is to establish the thermal limits of 19 selected demersal and benthopelagic species of fishes, crustaceans and cephalopods and the effects of global warming on their distributions in the Western Mediterranean Sea. First, we reviewed the literature regarding the temperature ranges where each species had been found. We also used global databases of species distribution and crossed them with temperature information to indentify a conservative range of optimal temperatures for each species. Once the thermal ranges were set, we compared them with the current projections of temperature evolution of Mediterranean waters to describe future changes in the suitable habitat of the studied species due to ocean warming.

Our results suggest that, under a business-as-usual scenario (i.e. Representative Concentration Pathway, RCP, 8.5), at the end of the XXI Century the potential habitat of 8 out of 19 species will be greatly reduced, while for 3 species will be moderately reduced and for 8 species there will not be any direct effect because of the warming.
\end{abstract}

Key words: Demersal fisheries, Thermal ranges, Sea warming, Habitat reduction. 


\title{
RECRUITMENT VARIABILITY OF THE STRIPED RED MULLET (MULLUS SURMULETUS) STOCK IN THE BALEARIC SEA (WESTERN MEDITERRANEAN)
}

\author{
Joaquim Tomàs-Ferrer*1,2, Ulla Fernandez-Arcaya ${ }^{1}$, Beatriz Guijarro ${ }^{1}$, Francesc \\ Ordines $^{1}$ and Enric Massutí ${ }^{1}$ \\ ${ }^{1}$ Instituto Español de Oceanografía - Centre Oceanogràfic de Balears, Palma, SPAIN. \\ joaquim.tomas@uib.cat,ulla.fernandez@ieo.es,beatriz.guijarro@ieo.es,xisco.ordinas@ieo.es, \\ enric.massuti@ieo.es \\ ${ }^{2}$ Universitat de les Illes Balears, Palma, SPAIN.
}

\begin{abstract}
The striped red mullet (M. surmuletus) is an important resource of the Mediterranean demersal fishery. The aim of the present study is to analyse the effects of the spawning stock condition, climate variability and fishing on the recruitment of the striped red mullet in the Balearic Islands (Western Mediterranean). For this purpose, we used the biological information collected from 29456 specimens of M. surmuletus. These individuals were sampled from 2000 to 2019 during the monthly biological samplings of the landings of the species carried oud within the Data Collection Framework and during the MEDITS surveys in the Balearic Islands. Size-independent measures of somatic condition and reproductive potential of spawning females were calculated. Time series of recruitment, spawning stock biomass (SSB) and fishing mortality were obtained from FAO-GFCM Stock Assessment. The time-series of four climate indices (NAO, IDEA, WeMOI and SST), already reported to have effects on Mediterranean fisheries, were also used. Generalised additive models (GAM) were used to assess i) the potential effect of SSG, spawners' condition and climate on recruitment and ii) the effect of recruitment, fishing mortality and climate on the SSB. The analyses showed that recruitment variability is mostly affected by SSB and spawners' reproductive potential. Recruitment of the two previous years along with fishing mortality are the two main factors determining the SSB, whereas any of the considered climatic indices was found to have a significant effect. Our results underline the usefulness of incorporating the condition parameters to the assessment and management of the fishing resources, as they would allow to make better predictions of the population dynamics under different scenarios of stock size and fishing mortality.
\end{abstract}

Key words: Mullus surmuletus, recruitment, spawners condition, population dynamics, fishing resources. 
Acknowledgments: This project has been co-funded by the EU through the European Maritime and Fisheries Fund (EMFF) within the National Program of collection, management and use of data in the fisheries sector and support for scientific advice regarding the Common Fisheries Policy.

\section{References:}

Hidalgo, M., Rouyer, T., Molinero, J. C., Massutí, E., Moranta, J., Guijarro, B. and Stenseth, N. C. (2011). Synergistic effects of fishing-induced demographic changes and climate variation on fish population dynamics. Marine Ecology Progress Series, 426, 1-12.

Levi, D., Andreoli, M. G., Bonanno, A., Fiorentino, F., Garofano, G., Mazzola, S., Norrito, G., Patti, B., Pernice, G. and Ragonese, S. (2003). The influence of hydrological features on the recruitment of red mullet (Mullus barbatus L. 1758) in the Strait of Sicily. Scientia Marina, 67(1), 259-268.

Massutí, E., Monserrat, S., Oliver, P., Moranta, J., López-Jurado, J. L., Marcos, M., Hidalgo, M., Guijarro, B., Carbonell, A. and Pereda, P. (2008). The influence of oceanographic scenarios on the population dynamics of demersal resources in the western Mediterranean: Hypothesis for hake and red shrimp off Balearic Islands. Journal of Marine Systems, 71(3-4), 421-438.

Quetglas, A., Ordines, F., Hidalgo, M., Monserrat, S., Ruiz, S., Amores, Á., Moranta, J. and Massutí, E. (2013). Synchronous combined effects of fishing and climate within a demersal community. ICES Journal of Marine Science, 70(2), 319-328. 


\title{
EVIDENCES OF SEXUAL SEGREGATION IN A COMMON DEEP- SEA SHARK: IMPLICATIONS FOR CONSERVATION AND MANAGEMENT
}

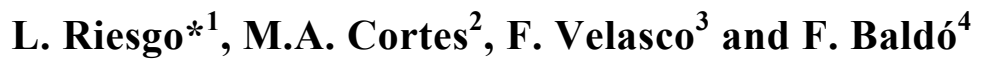 \\ ${ }^{1,4}$ Instituto Español de Oceanografía, C.O. de Cádiz, SPAIN. \\ lola.riesgo@hotmail.es,francisco.baldo@ieo.es \\ ${ }^{2}$ Instituto Español de Oceanografía, C.O. de les Balears, SPAIN. \\ miquelangelcortespujol@gmail.com \\ ${ }^{3}$ Instituto Español de Oceanografía, C.O. de Santander, SPAIN. \\ francisco.velasco@ieso.es
}

\begin{abstract}
Sexual segregation is a general characteristic of shark populations. Although many hypotheses have been proposed to explain sexual segregation as ethological, thermal or foraged-related reasons, how and why it occurs remains unsolved. Understanding sexbased spatio-temporal dynamics of elasmobranch species allow us to know how fishing sex-biased activities exacerbates their depletion. This is particularly important in deepwater sharks, due to their k-selected life history, which make them more vulnerable. Here we investigate the sexual segregation of the blackmouth catshark, Galeus melastomus, in relation to sex, size and maturity. Data originates from deep-water research trawl surveys carried out on Porcupine Bank (northeast Atlantic, west of Ireland) between 2001 and 2019. Our results show a clear spatial and bathymetric segregation among juveniles, mature males and females. Juveniles inhabit shallower waters $(<600 \mathrm{~m})$. Its great abundance compared to other areas of the northeast Atlantic, such as Rockall Through, indicates that this area could be an Effective Juvenile Habitat, where they reduce their mortality and increase their growth rates by reducing competition with adults. As they increase in size, they move into deeper waters, with females occupying the deepest strata. This behaviour could be explained by the fact that spatial segregation can allow females to take refuge from energetically expensive and damaging mating due to harassing. Therefore, we found that gravid females move to deeper strata, where they lay their eggs, maximizing the security and reducing risk of predation on them. Our research provides evidences of a lay-egg area used by blackmouth catshark, with important implications for its management.
\end{abstract}

Key words: Elasmobranch, Sexual segregation, North-east Atlantic, Spawning grounds, Nursery areas

Acknowledgments: The authors would like to thank the staff involved in the Spanish Bottom Trawl Survey on the Porcupine Bank (SP-PORC-Q3), which has been partially funded by the EU through the European Maritime and Fisheries Fund (EMFF). 


\title{
ADVANCING FOOD-WEB MODELLING CAPABILITIES TO ANALYSE GLOBAL OCEAN FUTURES
}

\author{
M. Coll ${ }^{1,2}$, J. Steenbeek ${ }^{2}$, J. Buszowski ${ }^{3}$, C. Garilao ${ }^{4}$, M. Grazia Pennino ${ }^{5}$, K.

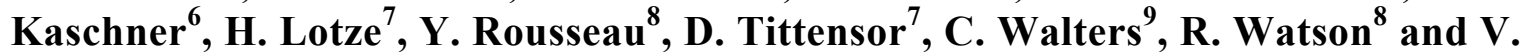 \\ Christensen? \\ ${ }^{1}$ Institute of Marine Science, ICM-CSIC, Barcelona, SPAIN. \\ mcoll@icm.csic.es \\ ${ }^{2}$ Ecopath International Initiative, EII, Barcelona, SPAIN. \\ jeroen@ecopathinternational.org \\ ${ }^{3}$ Mountainsoft, Canmore, CANADA. \\ joe@mountainsoft.net \\ ${ }^{4}$ Department of Biometry and Environmental System Analysis, Albert-Ludwigs-University of \\ Freiburg, Freiburg, GERMANY \\ cgarilao@geomar.de \\ ${ }^{5}$ Spanish Institute of Oceanography, Vigo, SPAIN. \\ grazia.pennino@ieo.es \\ ${ }^{6}$ GEOMAR Helmholtz-Zentrum für Ozeanforschung, Kiel, GERMANY. \\ Kristin.Kaschner@biologie.uni-freiburg.de \\ ${ }^{7}$ Dalhousie University, Biology Department, Halifax, CANADA. \\ Heike.Lotze@Dal.Ca,Derek.Tittensor@Dal.Ca \\ ${ }^{8}$ Institute for Marine and Antarctic Studies, University of Tasmania, Hobart, TASMANIA. \\ yannick.rousseau@utas.edu.au,rwatson@ecomarres.com \\ ${ }^{9}$ Institute for the Oceans and Fisheries, University of British Columbia, Vancouver, CANADA. \\ v.christensen@oceans.ubc.ca, c.walters@oceans.ubc.ca
}

\begin{abstract}
There has been considerable effort to predict the impact of climate change and anthropogenic activities on the biophysical environment, biodiversity, and marine resources at regional and global scales. To further our understanding of how changes in the environment and marine resources will affect marine ecosystems, there is a need for advancing global integrated assessments. We improved a previously developed spatialtemporal ecosystem model of the global ocean (EcoOcean) (Christensen et al., 2015), spanning food web dynamics from primary producers to top predators, and including worldwide fisheries. We enhanced its ability to reproduce spatial-temporal ecosystem dynamics by linking spatial-temporal species dynamics and distributions to main environmental conditions that change under climate impact (e.g. primary production, sea surface temperature), accounting for varying species compositions of species groupings over time and space (Coll et al., submitted). The updated modelling platform was used to simulate past and future scenarios of climate change and fisheries, considering structural uncertainty and alternative input drivers using standardized outputs from Earth-System Models (ESMs) and contrasting emission scenarios using the Representative Concentration
\end{abstract}


Pathways (RCPs) for historical (1950-2005) and future (2006-2100) periods. Ecological aggregated indicators and biomass from species groupings were used to compare ecological predictions among scenarios following a standardized protocol (Tittensor et al., 2019; Lotze et al., 2019). Comparing results from scenarios with and without fishing allowed us to evaluate how climate-driven responses differed between fished and hypothetically non-fished oceans. The study sets a baseline to further develop global ocean analyses and contribute to the quantification of cumulative effects assessment of multiple stressors and plausible ocean-based solutions to global change, considering species, biodiversity and food-web spatial-temporal dynamics.

Key words: Climate change, Fishing impact, Global ocean, Future trajectories

Acknowledgments: This study received funding from the European Union's Horizon 2020 research and innovation programme under grant agreement No 817578 (TRIATLAS project). The authors acknowledge the key contribution of the Fisheries and Marine Ecosystem Model Intercomparison Project (Fish-MIP) from the Inter-Sectorial Impact Model Intercomparison Project (ISIMIP).

\section{References:}

Coll, M., Steenbeek, J., Buszowski, J., Garilao, C., Pennino, G.M. et al. (submitted). Advancing global ecological modelling capabilities to analyse future trajectories of change in marine ecosystems. Frontiers in Marine Science.

Christensen, V., Coll, M., Buszowski, J., Cheung, W., Frölicher, T. et al. (2015). The global ocean is an ecosystem: Simulating marine life and fisheries. Global Ecology and Biogeography, 24 507-517.

Lotze, H.K., Tittensor, D.P., Bryndum-Buchholz, A., Eddy, T.D., Cheung, W.L. et al. (2019). Global ensemble projections reveal trophic amplification of ocean biomass declines with climate change. Proceedings of the National Academy of Science of the United States of America, 116, 12907-12912.

Tittensor, D.P., Eddy, T.D., Lotze, H.K., Galbraith, E.D., Cheung, W. et al. (2018). A protocol for the intercomparison of marine fishery and ecosystem models: Fish-MIP v1.0. Geoscientific Model Development, 11, 1421-1442. 


\title{
ECOSYSTEM RECOVERY 30 MONTHS AFTER THE 2011-2012 SUBMARINE VOLCANIC ERUPTION OFF EL HIERRO
}

\author{
M. Canals ${ }^{1}$, A. Aymà ${ }^{1}$ and the MIDAS-EI Hierro cruise shipboard party \\ ${ }^{1}$ GRC Marine Geosciences, Dept. of Earth and Ocean Dynamics, Faculty of Earth Sciences, \\ University of Barcelona, 08029 Barcelona, SPAIN. \\ miquelcanals@ub.edu,anna.ayma@gmail.com
}

\begin{abstract}
A submarine volcanic eruption from October 2011 to March 2012 off El Hierro Island, in the Canaries, provided an opportunity to investigate its impacts on and the recovery of the ecosystem by means of ROV inspection about 30 months after its cessation. The eruption led to the formation of a new volcanic cone and lava apron involving a major modification of the former seascape. The new cone grew from an initial water depth of $363 \mathrm{~m}$ to a final depth of $89 \mathrm{~m}$ at its summit, therefore involving a height difference of $274 \mathrm{~m}$, equivalent to a daily average vertical growth of $\sim 2 \mathrm{~m}$.
\end{abstract}

At about $130 \mathrm{~m}$ depth near the summit of the volcanic cone we found massive mats of long, white filaments that we named Venus's hair because of their appearance. They were made of bacterial trichomes enveloped within a sheath and colonized by epibiotic bacteria. Metagenomic analyses of the Venus's hair identified a new genus and species of the order Thiotrichales, Thiolava veneris, with a unique metabolic plasticity providing key competitive advantages for the colonization of the new habitat resulting from the eruption. A specialized and highly diverse food web thrived on the complex three-dimensional habitat formed by these microorganisms, showing that Venus's hair was playing a key role in the restart of biological systems after the eruption (Danovaro et al., 2017).

Furthermore, the presence and abundance of sessile (Anemona, Antipatharia, Brachiopoda, Briozoa, Cnidaria, Crinoidea, Hydroidea, sessile Mollusca, Serpulidae, Sponges and Tunicates) and motile (Cephalopoda, Crustacea, Ctenophora, Echinodermata, Echinoidea, Echiura, Foraminifera, Ophiura, Other fishes, Rays and Sharks) faunal groups along ROV dives suggest that the degree of impact on macrobenthic assemblages due to the eruption decreased rapidly with increasing distance to the volcanic cone. Actually, some sessile groups and species seem to have benefited (or at least not suffered) from the eruption after a rather short time, as they locally appear in high densities in the most impacted area or in densities higher that those in less impacted areas (i.e. the oyster N. zibrowii, Anthipataria black corals and Serpulidae, and some motile organisms such as Plesionika spp. shrimps and pelagic fishes over the cone summit).

Key words: Submarine volcanic eruption, Bacterial mat, Sessile organisms, Ecosystem recovery, El Hierro Island 


\section{References:}

Danovaro, R., Canals, M., Tangherlini, M., Dell'Anno, A. et al. (2017). A submarine volcanic eruption leads to a novel microbial habitat. Nature Ecology and Evolution, 1, 0144. 


\title{
ISOTOPIC DISTRIBUTION OF BLUE SHARK (Prionace glauca) IN THE WEST COAST OF BAJA CALIFORNIA SUR, MEXICO
}

\author{
R. Núñez-González ${ }^{1,2}$, A. Tripp-Valdez ${ }^{1}$ and F. Galván-Magaña ${ }^{1}$ \\ ${ }^{1}$ Departamento de Pesquerías y Biología Marina, Centro Interdisciplinario de Ciencias Marinas, \\ Instituto Politécnico Nacional, La Paz, BCS, MÉXICO. \\ raibel.nunez101@alu.ulpgc.es,atrippv@ipn.mx,galvan.felipe@gmail.com \\ 2 Present address: Departamento de Biología, Universidad de Las Palmas de Gran Canaria, \\ Facultad de Ciencias del Mar. Las Palmas de Gran Canaria, 35017 Gran Canaria, SPAIN.
}

\begin{abstract}
Blue shark (Prionace glauca), a key species in many ocean ecosystems, is caught in large numbers by fisheries around the world. The species is characterised by late sexual maturity and a long gestation period. All of this makes it to be considered as threatened. However, there is a lack of precise information about blue shark population, partly because the movement patterns of the species are unknown. Improving knowledge about the distribution and feeding habits together with the ontogeny of $P$. glauca could help understanding those patterns. Here we show the blue shark feeding ontogeny off the west coast of Baja California Sur (Mexico) using stable isotope analyses of carbon and nitrogen in vertebrae sections in juvenile and adult stages in order to obtain information about their distribution, either coastal or oceanic. The trophic level was estimated using values of copepods from the same region as trophic base. Additionally, we used the SIBER package ( $\mathrm{R}$ software) to determine isotopic overlaps between groups. We analysed 50 samples of vertebrae with $1: 1$ sexual proportion $\left(1: 1.19, \chi^{2}=0.8928 ; p>0.05\right)$. $\delta^{15} \mathrm{~N}$ yielded an average of $3.97 \pm 0.05$ for all stages, with similar values by sexes (i.e. females: $3.98 \pm 0.03$, and males: $4.02 \pm 0.1$ ), thus showing that $P$. glauca is a top predator. $\delta^{13} \mathrm{C}$ resulted in significant differences between stages $\left(\mathrm{F}_{2.97}=16.77, p=<0.0001\right)$ with adults showing the highest values, which is an indication that their distribution is coastal. We found low overlap $(<0.25)$ between stages and sexes. $\delta^{15} \mathrm{~N}$ values suggested a significant variation associated with ontogeny by sex, with higher migratory movements and temperature tolerance in females. These results demonstrate a significant variation of trophic niches between sexes and stages that could be associated to water temperature and prey availability. These results could help understanding the migratory behaviour of blue shark, which is highly relevant for long-term management plans for the species.
\end{abstract}

Key words: Blue shark, Isotope analyses, Ontogeny, Trophic level, Baja California Sur

Acknowledgments: We thank first the project "Tiburones y rayas de CICIMAR" and all the team that worked during years to collect the samples. We also thank CICIMAR-IPN and CONACYT for funding the Master studies of RNG. Last but not least, we are also 
grateful to the fishermen of the Pacific Coast of Baja California Sur for their help while sampling and for providing pieces of sharks to continue doing research in this amazing ecosystem. Our thanks go to the Stable Isotope Laboratory at Instituto Andaluz de Ciencias de la Tierra too, in Granada, Spain, and especially to Dr. Antonio Delgado Huertas and Dr. Arsenio Granados, for their help in processing all the samples during a research stay. 


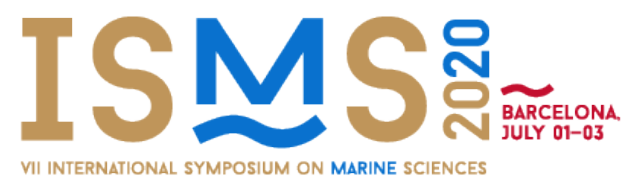

VII International Symposium on Marine Sciences

ISMS 2020

Barcelona (Spain), $1^{\text {st }}-3^{\text {rd } J u l y ~} 2020$

\section{SPATIO-TEMPORAL VARIABILITY OF AMPHIPOD ASSEMBLAGES ASSOCIATED WITH RHODOLITH SEABEDS}

\begin{abstract}
Maërl (rhodolithic) beds are habitats underpinned by rhodoliths, which are distributed worldwide within the photic zone, from the intertidal down to $200 \mathrm{~m}$ depth. The morphology of individual rhodoliths is directly affected by physical processes, such as the degree of hydrodnamism and light availability, which typically change with depth. Concurrently, epiflora attached on rhodoliths can experience both seasonal and depth variation; consequently, epifauna living associated with rhodoliths can respond to such changes. In this study, we partitioned the relevance of scales of temporal (four seasons through two years) and spatial (three depth strata: 18, 25 and $40 \mathrm{~m}$ ) variation on the diversity, structure and abundances of amphipod assemblages living in maërl beds of Gran Canaria Island (eastern Atlantic). On each depth stratum, five random replicates ( $25 \times 25$ $\mathrm{cm}$ ) were taken each time, by collecting all rhodolith nodules up to $5 \mathrm{~cm}$ inside the sea bottom. A total of 3,996 individuals, belonging to 32 taxa, were here identified.

Multivariate analysis of the amphipod assemblage structure revealed consistent differences between depths; more diverse and abundant amphipod assemblages were observed at 18 and $25 \mathrm{~m}$ depth relative to $40 \mathrm{~m}$. This pattern was particularly related to the epiphytic algal biomass, which was also greater at 18 and $25 \mathrm{~m}$ depth. Among these species, $G$. ostroumowi and $A$. ramondi dominated the assemblage. For both species, ovigerous females were observed throughout the entire study, with larger abundances at 18 and $25 \mathrm{~m}$ for $G$. ostroumowi and A. ramondi. Juveniles of both species were exclusively recorded at 18 and $25 \mathrm{~m}$, being absent at $40 \mathrm{~m}$. A peak of juveniles of both species occurred in spring, most likely linked with the larger biomass of epiphytic algae. In summary, this study has demonstrated that the assemblage of amphipods associated with rhodolith seabeds can greatly vary across scales of both spatial (depth) and time (seasons), in particular due to variation in the amount of epiphytic algae attached to rhodoliths, which therefore seem to provide key resources for associated amphipods
\end{abstract}




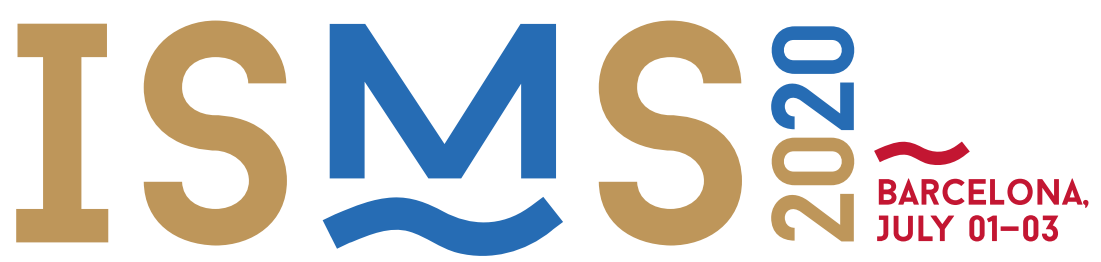

VII INTERNATIONAL SYMPOSIUM ON MARINE SCIENCES BARCELONA
JULY 01-03

ORAL COMMUNICATIONS

\section{MARINE} GEOSCIENCES 


\title{
UNRAVELLING THE CHEMICAL SIGNATURE OF ALBORAN SEA SEDIMENTS TO DETECT HOLOCENE HUMIDITY CHANGES IN SOUTHERN IBERIA
}

\author{
A. Català ${ }^{* 1}$, I. Cacho ${ }^{1}$, L.D. Pena ${ }^{1}$, E. Garcia-Solsona ${ }^{1}$, E. Paredes ${ }^{1}$, J. Frigola ${ }^{1}$, A. \\ Sanchez-Vidal ${ }^{1}$, A. Calafat ${ }^{1}$ and M. Canals ${ }^{1}$ \\ ${ }^{1}$ GRC Geociències Marines, Departament de Dinàmica de la Terra i de l'Oceà, Facultat de \\ Ciències de la Terra, Universitat de Barcelona, SPAIN. \\ al_catala@ub.edu,icacho@ub.edu,lpena@ub.edu,e.garcia@ub.edu,eduardo.paredes@ub.edu, \\ jfrigola@ub.edu,anna.sanchez@ub.edu, antonicalafat@ub.edu, and miquelcanals@ub.edu
}

\begin{abstract}
The Mediterranean Sea and the surrounding continents are vulnerable regions to hydrological changes. In the context of predicted climate changes, it is particularly challenging to understand the response of the hydrological conditions of the region both to warmer temperatures and to the foreseen oceanographic changes in the Mediterranean Sea but also in the Atlantic Ocean. In this regard, the sediment core ALB-2 from the Alboran Sea provides an exceptional high-resolution marine record of the Holocene including the $\mathrm{Mg} / \mathrm{Ca}$-derived SST record from Globigerina bulloides. This record tests the sensitivity of southern Iberia climate to changes in the NE Atlantic region, thus framing the regional sensitivity to the predicted weakening in the AMOC (Català et al., 2019). This study targets the chemical characterization of the terrigenous fraction of ALB-2 core in order to identify potential changes in rainfall patterns. Results from geochemical XRF-core-scanner analyses allow establishing a clear relation with some elements associated with rainfall changes over land. We find the most humid conditions while were recorded the warmest SSTs during the early to middle Holocene. A clear transition towards drier conditions and colder SST occurred by the end of the middle Holocene, with the most extreme conditions taking place in the late Holocene. Further we applied radiogenic $\mathrm{Sr}, \mathrm{Nd}$ and $\mathrm{Pb}$ isotopes to discriminate the relative dominance of riverine vs. aeolian-sourced particles, so that the provenance of the particles in the sedimentary record could be ascertained. In this respect, we developed an innovative approach by applying this technique first to modern sediment samples from moored traps while establishing the links with meteorological events. The aim was to obtain the key isotopic signature associated to specific humid-dry short-term events. Here we discuss the preliminary results from that approach in order to test the initial hypothesis based on XRF-core-scanner analyses.
\end{abstract}

Key words: Terrigenous Inputs, Transport Mechanisms, Radiogenic Isotopes, Holocene, Mediterranean Sea. 
Acknowledgments: This study has received funding from the European Research Council (ERC) under the European Union's Horizon 2020 research and innovation program through the ERC-Consolidator project TIMED (Grant Agreement No. 683237) and from the Spanish project CHIMERA (CTM2016-75411-R).

\section{References:}

Català, A., Cacho, I., Frigola, J., Pena, L. D., \& Lirer, F. (2019). Holocene hydrography evolution in the Alboran Sea: a multi-record and multi-proxy comparison. Climate of the Past, 15(3), 927-942. http://doi.org/10.5194/cp-15-927-2019 


\title{
MARINE SUBSOIL INVESTIGATIONS FOR OFFSHORE WIND FARMS AND SUBMARINE INTERCONNECTION CABLES
}

\author{
A. Deu Lozano* ${ }^{1}$, M. Devincenzi Fabetti ${ }^{2}$ and R. Del Castillo ${ }^{3}$ \\ ${ }^{1}$ Technical Director, IGEOTEST. Figueres (Girona), SPAIN. \\ amadeu@igeotest.com \\ ${ }^{2}$ CEO. IGEOTEST. Figueres (Girona), SPAIN. \\ marcelo@igeotest.com \\ ${ }^{3}$ General Manager. IGEOTEST. Figueres (Girona), SPAIN. \\ rafaelnc@igeotest.com
}

\begin{abstract}
: the knowledge of the marine subsoil is a fundamental fact for the correct development and design of any structure that has to be installed offshore. In the case of offshore wind farms or submarine interconnections, an accurate definition of soil/rock properties is directly related to a realistic design of turbines (either with direct foundation in the ground or floating) and substations, as well as the determination of the suitable trajectory for the cable inside the park (inter-array cable) and the link between park with the shore (export cable). In this sense, the combination of geophysical and geotechnical techniques allows optimizing marine investigations surveys and obtaining more precise subsoil models in terms of morphology and properties of interest of the different units involved. Nevertheless, it takes time to achieve enough level to carry out highly demanded marine geophysical and geotechnical surveys for these projects in often complex working areas.

The experience in marine investigations in countries where the offshore wind industry has been developed during the last years has allowed defining the most suitable geophysical and geotechnical techniques, the necessary equipment to be used and the vessel requirements that have to be considered to undertake successfully these projects.

This paper summarises and analyses the acquired experience in subsoil marine investigations for the installation of offshore wind farms and submarine cables in Spain, France and North Sea. Some examples related to the integration between geophysical and geotechnical data are included.
\end{abstract}

Key words: marine geosciences, offshore wind farms, seafloor characterization, submarine cable 


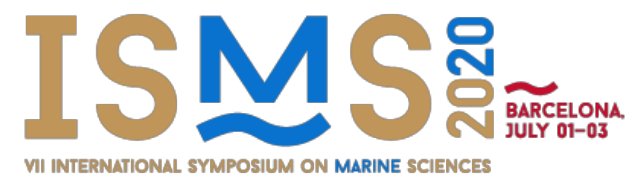

VII International Symposium on Marine Sciences

ISMS 2020

Barcelona (Spain), $1^{\text {st }}-3^{\text {rd }}$ July 2020

\section{THERMAL PROPERTIES OF MARINE SEDIMENTS}

\author{
A. Deu Lozano*1 ${ }^{1}$, M. Devincenzi Fabetti ${ }^{1}$ and R. Del Castillo ${ }^{1}$ \\ ${ }^{1}$ IGEOTEST, Figueres (Girona), SPAIN. \\ amadeu@igeotest.com, \\ marcelo@igeotest.com, \\ rafaelnc@igeotest.com
}

\begin{abstract}
The need for electrical interconnection between different regions as well as the proliferation of offshore wind farms all over the world has led to the installation of hundreds of kilometres of submarine electric cables in recent years. In addition, the large number of projects pending of execution, as well as those currently under way, ensures a notable increase in this type of operations over the next few years.
\end{abstract}

For a proper design of the geometry and the insulation type for each cable it is essential to determine with high reliability both the thermal and geotechnical properties of the soil/rock in which the cable is going to be laid or buried. In this sense, the maximum operating temperature is crucial for the operation, maintenance, useful life and actual capacity of energy transfer through this type of cables (Dix et al., 2017). The soil behaviour against thermal increase will directly influence the quality of the operation since a "cool" cable is more effective for electric transmission (Müller et al., 2016).

This paper analyses the different methodologies to measure the temperature and thermal conductivity of marine soils. Some results acquired during several offshore site investigations in different types of marine soils using in-situ equipment and manual probes will be presented and the reliability of these results subsequently analysed.

Key words: In-situ temperature measurements, Marine geosciences, Seafloor characterization, Thermal properties of sediments

\section{References:}

Dix, JK., Hughes, TJ., Emeana, CJ., Pilgrim, JA., Henstock, TJ., Gernon, TM., Thompson, CEL., Vardy, ME. 2017. Substrate controls on the life-time performance of marine HV cables. Proc. 8th Int. Conf. Offshore Site Investigation and Geotechnics. SUT. 88-108.

Müller, C., Usbeck, R., Miesner, F. 2016. Temperatures in shallow marine sediments: Influence of thermal properties, seasonal forcing, and man-made heat sources. Applied Thermal Engineering. 108, 20-29. 


\title{
TEMPERATURE AND CONDUCTIVITY ANOMALIES AS A PROXY FOR VOLCANIC ACTIVITY AT THE TAGORO SUBMARINE VOLCANO IN THE CANARY ISLANDS
}

\author{
Anna Olivé Abelló ${ }^{1 *}$, Beatriz Vinha ${ }^{2}$, Francisco Machín ${ }^{3}$, Francesco Zerbetto ${ }^{4}$, Evangelos \\ Bakalis ${ }^{4}$ and Eugenio Fraile-Nuez ${ }^{2}$. \\ ${ }^{1}$ Departamento de Oceanografía Física y Tecnológica, Institut de Ciències del Mar, Barcelona, SPAIN. \\ aolive@icm.csic.es \\ ${ }^{2}$ Instituto Español de Oceanografia, 38180, Santa Cruz de Tenerife, SPAIN. \\ beatrizvinha95@gmail.com; eugenio.fraile@ieo.es. \\ ${ }^{3}$ Universidad de Las Palmas de Gran Canaria, 35017 Las Palmas de Gran Canaria, SPAIN. \\ francisco.machin@ulpgc.es. \\ ${ }^{4}$ Dipartimento di Chimica "G. Ciamician”, Universitàdi Bologna, Bologna BO, ITALY. \\ francesco.zerbetto@unibo.it,evangelos.bakalis2@unibo.it
}

\begin{abstract}
Temperature and conductivity fluctuations due to the hydrothermal emissions released during the degasification stage of the Tagoro submarine volcano, off El Hierro Island in the Canary Archipelago, may provide robust indicators for characterising and predicting the activity of the system. 21 CTD time series along a regular high-resolution grid were gathered in the VULCANO1016 cruise with the rosette sampler directly over the main seafloor crater (Santana-Casiano et al., 2016; Fraile-Nuez et al., 2018). Temperature and conductivity data compiled are analysed as manifestations of stochastic processes in terms of the Generalized Moments Method (GMM) (Bakalis et al., 2017; Bakalis et al., 2018). GMM provides the statistical moments of the underlying processes and delivers their structure functions being their shape an indicator of the stochastic mechanism/s governing such a stochastic process. Our findings point to an active submarine volcano, which conveys energy to the surrounding ecosystem. Yet, both temperature and conductivity fluctuations present long tails depict to strong sub-normal processes, which change very slowly in the long time limit. Temperature and conductivity fluctuations are classified as multifractal processes whose structure functions show a crossover in two distinct regimes. Multifractality suggests the multiplicative action of at least two random processes, which can be attributed to the volcano and to the aquatic environment. From the physical view point the Tagoro submarine volcano can be defined as an open system given the variations over time of temperature moments.
\end{abstract}

Key words: Tagoro submarine volcano, hydrothermal vents, stochastic processes, Canary Archipelago.

Acknowledgements: This study has been supported by funds from FEDER and the Spanish Ministry of Economy and Competitiveness through VULCANA-II (IEO2018-2020) and VULCANO-II (CTM2014-51837$\mathrm{R})$ research projects.

\section{References:}

Bakalis, E., Mertzimekis, T. J., Nomikou, P., and Zerbetto, F. (2017). Breathing modes of Kolumbo submarine volcano (Santorini, Greece). Scientific Reports, 7, 46515. 
Bakalis, E., Mertzimekis, T. J., Nomikou, P., and Zerbetto, F. (2018). Temperature and conductivity as indicators of the morphology and activity of a submarine volcano: Avyssos (Nisyros) in the South Aegean Sea, Greece. Geosciences, 8 (6), 193.

Fraile-Nuez, E., Santana-Casiano, J. M., González-Dávila, M., Vázquez, J. T., Fernández-Salas, L.M., Sánchez-Guillamón, O., and Presas-Navarro, C. (2018). Cyclic behavior associated with the degassing process at the shallow submarine volcano Tagoro, Canary Islands, Spain. Geosciences, 8 (12), 457.

Santana-Casiano, J.M., Fraile-Nuez, E., González-Dávila, M., Baker, E.T., Resing, J.A., and Walker, S.L. (2016). Significant discharge of $\mathrm{CO}_{2}$ from hydrothermalism associated with the submarine volcano of El Hierro Island. Scientific Reports, 6, 25686. 


\title{
CREATING A 3D SEISMIC CUBE FROM 2D HIGH-RESOLUTION SEISMIC PROFILES. A CASE STUDY FROM THE MARINE MINE TAILINGS DEPOSIT IN PORTMÁN BAY, SPAIN
}

\author{
Soldevila E. * ${ }^{1}$, Carbonell R. ${ }^{2}$, Alcalde J. ${ }^{2}$, Amblas D. ${ }^{1}$ and Canals M. ${ }^{1}$ \\ ${ }^{1}$ Department of Earth and Ocean Dynamics, Faculty of Earth Sciences, University of Barcelona, \\ Barcelona, SPAIN. \\ emma.soldevila@ub.edu,damblas@ub.edu,miquelcanals@ub.edu \\ ${ }^{2}$ Institue of Earth Science Jaume Almera (ICTJA), Spanish National Research Council (CSIC), \\ Barcelona, SPAIN. \\ ramon.carbonell@csic.es,jalcalde@ictja.csic.es
}

\begin{abstract}
High-resolution (HR) 3D seismic acquisition is often not available. This work builds an optimized workflow to convert a dense 2D HR seismic grid into a 3D seismic volume. The task has been developed within a broader project, NUREIEVA, which aims at characterizing a metal-rich onshore and shallow marine mine tailings deposit in Portmán Bay, Murcia, Spain. Hence, in the framework of the NUREIEVA project a very dense set of 2D HR seismic lines was acquired using a hull-mounted Kongsberg TOPAS PS18 single-channel parametric source. The acquired seismic grid consisted of 1309 2D lines, with an approximate distance between lines of $10 \mathrm{~m}$, covering an area of $7.45 \mathrm{~km}^{2}$ and yielding a vertical resolution of $15 \mathrm{~cm}$, very high if compared to conventional seismic reflection data.
\end{abstract}

In order to visualize the internal architecture of the mine tailings deposit in all directions, it is desirable to convert the dense $2 \mathrm{D}$ network of lines into a full 3D data volume. For this purpose, a new optimized 2D to 3D conversion processing flow has been designed. Given the specific characteristics of the input data, a number of challenges had to be addressed, namely: (i) a very high vertical resolution that differs by at least two orders of magnitude from the horizontal resolution; (ii) a large data volume (2 TB), which involves extensive computing time; (iii) the heterogeneity in the acquisition parameters. Because of this, the lines had to be processed previously to the $3 \mathrm{D}$ interpolation to homogenize the imaging characteristics and signal content. This new methodology can be now applied for obtaining a $3 \mathrm{D}$ volume to any case where a single channel dense $2 \mathrm{D}$ seismic grid is available. Furthermore, if duly adapted to each particular scenario, it represents a low cost alternative to conventional HR 3D seismic and could prevent further seismic shooting.

Key words: Seismic reflection profiling, TOPAS, 2D to 3D model, Portmán Bay 


\title{
THE FAST TRANSFORMATION OF THE MEDITERRANEAN DEEP SEAFLOOR
}

\author{
Miquel Canals ${ }^{1}$ \\ ${ }^{1}$ GRC Marine Geosciences, Dept. of Earth and Ocean Dynamics, Faculty of Earth Sciences, \\ University of Barcelona, 08029 Barcelona, SPAIN \\ miquelcanals@ub.edu
}

\begin{abstract}
The deep Mediterranean seafloor is experiencing a fast, unprecedented transformation that will leave a perennial footprint while seriously compromising habitat health. This is largely caused by deep water bottom trawling, oil and gas exploration and production, submarine pipelines and cable lying, and dumping of hazardous substances.
\end{abstract}

Bottom trawling is by far the most extensive of these activities, and has already caused major, permanent seascape alterations, habitat destruction and impairment of ecosystem services (Puig et al., 2012; Pusceddu et al., 2014). To date oil and gas exploration and production mostly concentrate in the Eastern Mediterranean Basin, where some major discoveries have been made recently. Hydrocarbon resource exploitation involves the laying of extensive networks of pipelines and other seabed structures that ideally should be removed following field exhaustion. Such pipelines and structures represent a growing impact factor on the deep seabed together with, though to a lesser extent, communication cables and rare electrical submarine cables. Waste dumping in the deep Mediterranean has been performed locally. Their impacts seem to be limited in extent though they may be severe at dumping sites and their surroundings, as observed for instance in the Cassidaigne and Planier submarine canyons in the Gulf of Lion and in Antikyra Bay in Greece (both because of red muds from aluminium processing) or in the Levant Basin off Israel (because of coal fly ash and contaminated dredging materials and industrial waste).

So far there is no sign that pressures and impacts on the deep Mediterranean seafloor will diminish in the near future but the opposite. Only persistent global crisis are able to slow down that trend. Not only some tipping points have been already exceeded (e.g. seabed metric-scale geomorphic shift because of bottom trawling), but also efforts presented as to protect the deep seafloor, such as Fisheries Restricted Areas (FRAs), appear undermined since their inception. At present, most of the area of Mediterranean FRAs is deeper than $1,000 \mathrm{~m}$, i.e. they extend over regions where living resources are extremely scarce and thus bottom trawling is not practiced. Once more, what is protected mostly is marginal land.

Key words: Deep seafloor, bottom trawling, oil and gas, waste dumping, Mediterranean Sea.

Puig, P., Canals, M., Company, J.B., Martín, J. et al. (2012). Ploughing the deep seafloor. Nature, 489, 286290.

Pusceddu, A., Bianchelli, S., Martín, J., Puig, P. et al. (2017). Chronic and intensive bottom trawling impairs deep-sea biodiversity and ecosystem functioning. PNAS, 111, 8861-8866. 


\title{
GEOMETRY, STRUCTURE AND STABILITY OF THE SUBMARINE EXTENSION OF THE MINE TAILINGS DEPOSIT OF PORTMÁN BAY, SPAIN
}

\author{
Nil Rodes ${ }^{1}$, Miquel Canals ${ }^{1}$ David Amblas ${ }^{1}$, Emma Soldevila ${ }^{1}$, Ramon Carbonell ${ }^{2}$, \\ Galderic Lastras ${ }^{1}$, Anna Sanchez-Vidal ${ }^{1}$, A. and NUREIEVA-MAR 1 Shipboard Party \\ ${ }^{1}$ CRG Marine Geosciences, Dept of Earth and Ocean Dynamics, Faculty of Earth Sciences, \\ University of Barcelona, Barcelona, Spain \\ nilrodes@yahoo.com,miquelcanals@ub.edu,damblas@ub.edu,emma.soldevila@ub.edu, \\ glastras@ub.edu,anna.sanchez@ub.edu \\ ${ }^{2}$ Dept. Structure \& Dynamics of the Earth, CSIC-Institut de Ciències de la Terra Jaume Almera, \\ Barcelona, Spain \\ ramon.carbonell@csic.es
}

From 1957 to 1990, large amounts of tailings from open-pit sulphide mining inland were dumped into Portmán Bay, Murcia (SE of Spain), one of the worse cases of coastal pollution by mine waste in the Mediterranean Sea and Europe. Tailings containing high concentrations of $\mathrm{Fe}, \mathrm{Pb}, \mathrm{Zn}, \mathrm{Cd}$ and As were spilled directly into the sea. The most visible consequence of the dumping is the infill of the bay and the seaward shift of the original coastline by 500 to $600 \mathrm{~m}$. However, the largest and less known part of the tailings deposit is underwater, on the adjacent continental shelf.

This study aims to evaluate the extent, geometry, structure and stability of the submerged deposit. Multibeam bathymetry data and high-resolution seismic reflection profiles were acquired off Portmán Bay during the oceanographic cruise NUREIEVA-MAR-1, performed in 2018 onboard RV Ángeles Alvariño, in the framework of the NUREIEVA research project.

The submerged part of the mine tailings deposit extends down to $45 \mathrm{~m}$ water depth, sealing about $5 \mathrm{~km}^{2}$ of the original seafloor. The submarine deposit displays a prograding coastal prism consisting of three distinct lobes that extend up to $3 \mathrm{~km}$ offshore. Some pre-existing lineal bedrock outcrops acted as natural barriers preventing further spreading of the tailings. The submarine deposit includes a proximal prodelta-like front with a maximum thickness of $23 \mathrm{~m}$, showing instability signs in the form of creep folds. Accumulation rates in the front area have been calculated to be very high $(\sim 0.7 \mathrm{~m} /$ year on average) during the dumping period.

Whereas a remediation plan started inshore in 2018, eventual remediation actions of the much larger and extensive submarine deposit pose many uncertainties 
This study brings new insights to accurately characterize and size the mine tailings deposit of Portmán Bay, which are much needed by decision-makers.

Key words: Portmán Bay, mine tailings deposit, sedimentary instability, remediation.

Acknowledgments: This work is part of the project NUevos REtos de Investigación en el ambiente Extremo de los Vertidos mineros de la Bahía de Portmán: aplicación de tecnologias Avanzadas (NUREIEVA, CTM2016-75953-C2-1-R), financed by the Spanish Ministry of Economy and Competitiveness (MINECO). 


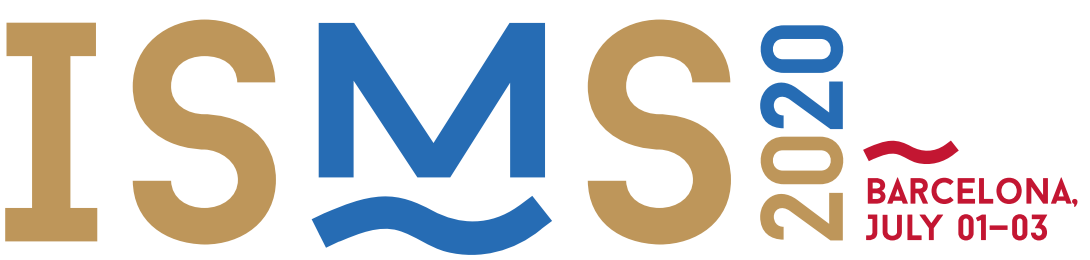

VII INTERNATIONAL SYMPOSIUM ON MARINE SCIENCES

\section{ORAL \\ COMMUNICATIONS}

MICROBIOLOGY,

GENETICS,

BIOTECHNOLOGY

AND MOLECULAR

BIOLOGY 


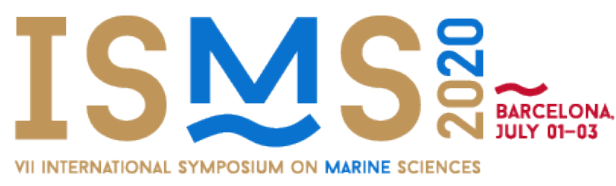

\section{IMAGING FLOW CYTOMETRY AS A TOOL FOR THE STUDY OF CYANOBACTERIAL AGGREGATION}

\author{
D. Iglesias-Arroyo ${ }^{* 1}$, B. Ubeda ${ }^{2}$, F.R. Piedras ${ }^{3}$ and A. Bartual ${ }^{4}$ \\ ${ }^{1,2,4}$ Institute of Marine Science and Technologies (INMAR), University of Cádiz, Puerto Real, \\ Cádiz, SPAIN. \\ diana.iglesiasarroyo@alum.uca.es; barbara.ubeda@uca.es; ana.bartual@uca.es \\ ${ }^{3}$ Faculdade de Oceanografia, Universidade do Estado do Rio de Janeiro, Rio de Janeiro, BRAZIL. \\ piedrasfernanda@gmail.com
}

\begin{abstract}
Picocyanobacteria (Synechococcus and Prochlorococcus) are the most abundant and widespread phytoplankton in the global ocean (Scanlan et al., 2009). As a consequence of their small size $(<2 \mu \mathrm{m})$, flow cytometry, genomic tools and scanning microscopy are necessary for their study and observation. Flow cytometry have contributed to many important oceanographic discoveries regarding this phytoplanktonic group (Chisholm et al., 1988). At present, imaging flow cytometry (IFC) combine cytometry with optical microscopy, getting a gallery of images associated to each particulate quantified by flow cytometry that appear as a dot in the resulting cytogram. This offer a fantastic tool to analyze more accurately morphometric features (size and shapes) of single cells and microcolonies of small sized organisms as cyanobacteria. It has been hypothesized that picoplankton, including Synechococcus, contribute significantly to particulate organic carbon export in the ocean, via formation and gravitational settling of aggregates and/or consumption of those aggregates by mesozooplankton (Lomas and Moran, 2011). Here we used IFC (Image Stream $\left.{ }^{\mathrm{X}} m k \mathrm{II}\right)$ to study the effect of diatom exudates in the aggregation of a coastal marine cyanobacterium Synechococcus sp. PCC 7002. We used a $100 \mu \mathrm{m}$ aperture tube for collecting samples of triplicated xenic cultures of Synechococcus, grown at enriched seawater (Control) and enriched seawater + diatom exudates (Exudated). The temporal evolution (7 days) of the percentage of suspended aggregates and morphometric features of single cells and aggregates were compared for both conditions. The strain used showed an averaged cell length of $1.85 \pm 0.39 \mu \mathrm{m}$. As main results, we found that after $24 \mathrm{~h}$ of exposition to diatom exudates the percentage of aggregates of Synechococcus constituted the $48 \%$ of total cell abundance, compared with a $5.5 \%$ at control conditions. These aggregates reached maximal area of $1040 \mu \mathrm{m}^{2}$ compared with maximal area of $247 \mu \mathrm{m}^{2}$ for control conditions.
\end{abstract}

Key words: Aggregation, Cyanobacteria, Imaging flow cytometry, Synechococcus

Acknowledgments: D.I. thanks to the Faculty in Marine and Environmental Science of the University of Cádiz for the scholar grant to attend this Symposium. This research was supported by FICOEXPLORA-project (Ref. RTI2018-101272-B-I00) funded by the 
Ministry of Science, Innovation and Universities from Spanish Goberment.

\section{References:}

Scanlan, D. J., Ostrowski, M., Mazard, S., Dufresne, A., Garczarek, L., Hess, W. R., et al. (2009). Ecological genomics of marine picocyanobacteria. Microbiol. Mol. Biol. Rev. 73, 249-299. doi: 10.1128/MMBR.00035-8

Chisholm, S.W., Olson R.J., Zettler, E.R., Goericke R., Waterbury J.N. and Welschmeyer, N.A. (1988). A novel free-living prochlorophyte abundant in the oceanic euphotic zone. Nature 334, 340-343.

Lomas, M.W. and Moran, S.B. (2011). Evidence for aggregation and export of cyanobacteria and nanoeukaryotes from the Sargasso Sea euphotic zone. Biogeosciences, 8, 203-216. 


\title{
PREDICTING 2b-RAD LOCI ABUNDANCE AND TESTING RESULTS IN STYELA PLICATA
}

\author{
Carles Galià-Camps* $^{* 1}$, Carlos Carreras ${ }^{1}$, Xavier Turon ${ }^{2}$ and Marta Pascual ${ }^{1}$ \\ ${ }^{1}$ Departament de Genètica, Microbiologia i Estadística - IRBio, Universitat de Barcelona, \\ Avinguda Diagonal 643, 08028 Barcelona, Spain. \\ ${ }^{2}$ Centre d'Estudis Avançats de Blanes (CEAB, CSIC), Accés Cala St. Francesc 14, 17300 \\ Blanes, Girona, Spain. \\ carlesgalia@ub.edu,carreras@ub.edu,xturon@ceab.csic.es,mpascual@ub.edu
}

\begin{abstract}
Population genomic studies can be performed in organisms lacking reference genomes. When starting with a new species it is important to refine protocols to optimize economic resources without compromising the quality of the data generated. RAD markers reduce the fraction of the genome to be analysed and consequently it is crucial to determine how many loci are expected from digestions, due to the trade-off between the number of loci and sequencing depth. Considering the variety of $2 b-R A D$ enzymes, each with their own DNA target sequences, and the diversity of genome sizes, it is desirable to assess general patterns of loci abundance and loci uniqueness to predict each enzyme utility in population genomic studies. We used the phyper script ${ }^{[1]}$ to perform "in-silico" digestions on wellannotated genomes belonging to 82 different species of vertebrates, invertebrates and plants. We simulated digestions with AlfI, BaeI and CspCI 2b-RAD enzymes and we recorded the total and unique loci number obtained for each combination of species and enzyme. Our "insilico" results demonstrate that CspCI is the enzyme with the best correlation between loci number and genome size. Moreover, CspCI and AlfI have similar number of unique loci. Since we aim to use 2b-RAD sequencing on the global invader Styela plicata to track invasion routes and search for signals of adaptation, we constructed $S$. plicata libraries for the two best enzymes: CspCI and AlfI. However, only AlfI was able to digest its genome. Given that the expected number of loci for AlfI is larger than CspCI, we constructed libraries with and without selective base ligation to reduce the number of assayed loci ${ }^{[2]}$. Thus, although "in silico" simulations can be used to predict the number of loci, it is important to also test the enzymes in real DNA samples in order to determine its suitability.
\end{abstract}

Key words: "in-silico" digestions, 2b-RAD libraries, selective base ligation, invasive ascidian

Acknowledgments: This work was supported by project PopCOmics (CTM2017-88080 MCIU, AEI/FEDER/UE). All authors are part of the research group SGR2017-1120. CG was supported by the PhD scholarship PRE2018-085227. 


\section{References:}

[1] Seetharam, A. S., and Stuart, G. W. (2013). Whole genome phylogeny for 21 Drosophila species using predicted 2b-RAD fragments. PeerJ, 1, e226.

[2] Barbanti, A., Torrado, H., Macpherson, E., Bargelloni, L., Franch, R., Carreras, C., and Pascual, M. (2020). Helping decision making for reliable and cost- effective $2 \mathrm{~b}$ - RAD sequencing and genotyping analyses in non- model species. Molecular Ecology Resources. doi: 10.1111/1755-0998.13144 


\title{
RESPIRATION, PROTEIN, LIPID \& CARBOHYDRATE COMPOSITION IN Physalia physalis AND Velella velella. PREDATOR AND PREY OF THE PLEUSTON.
}

\author{
Daniel R. Bondyale-Juez ${ }^{* 1}$, Vanesa Romero-Kutzner ${ }^{1}$, Theodore T. Packard ${ }^{1}$, Ico \\ Martínez $^{1}$ and May Gómez ${ }^{1}$ \\ ${ }^{1}$ Marine Ecophysiology Group (EOMAR); IU-ECOAQUA, Universidad de Las Palmas de \\ Gran Canaria 35017, Canary Islands, Spain. \\ daniel.bondyale101@alu.ulpgc.es,vanesa.romero.kutzner@gmail.com, \\ theodore.packard@ulpgc.es,ico.martinez@ulpgc.es,may.gomez@ulpgc.es
}

\begin{abstract}
:
In the unstable environment between the air and the sea lives a community of organisms, the pleuston. Two of the main representants of this community are Physalia physalis and Velella velella, two colonial organisms that have worldwide distribution thanks to their pneumatophore and sail, chitin structures that allow them to use wind propulsion. Like other gelatinous zooplankton, these hydrozoans are sometimes overlooked members of ecosystems. However, they are predators and competitors of fish and also prey for a wide variety of organisms including pleustonic molluscs, crustaceans, fish and turtles. In this work we study the respiratory metabolism and proximate composition of these organisms to estimate their respiratory carbon demand (RCD) and energy content (Ec) to quantify their effects as predators and understand their value as preys. Respiration was measured using incubations with optodes to determine the rate of decrease of oxygen concentration i.e. physiological respiration (R). Enzyme kinetic analysis of the electron transport system (ETS) was also used to test the application of enzymatic techniques on these organisms and calculating potential respiration (Ф). The protein, lipid and carbohydrate contents of the samples were measured spectrophotometrically following their respective assays in the literature. The water content in these organisms was lower than other gelatinous zooplankton so results were converted to dry mass (DM) specific. The proximate composition results fell inside the range for gelatinous zooplankton in the literature with slightly higher protein and lipid content. The Ec associated was in general higher than other gelatinous species excluding arctic specimens. The respiratory metabolism of both hydrozoans was similar. The low R: $\Phi$ ratio compared to previous studies on zooplankton could be due to their drifting fairly inactive lifestyle compared to other members of the gelatinous zooplankton. The RCD associated was slightly below the range of carbon ingestion calculated from feeding studies.
\end{abstract}

Key words: Hydrozoan, Physalia physalis, Velella velella, Respiration, Proximate composition 
Acknowledgments: The PERSEO project (ProID201710051) of the Canary Island government and ERDF funds granted to M.G. supported this study. 


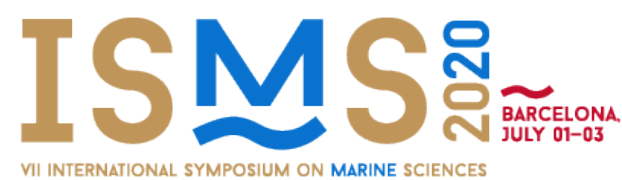

VII International Symposium on Marine Sciences

ISMS 2020

Barcelona (Spain), $1^{\text {st }}-3^{\text {rd }}$ July 2020

\section{COMPARATIVE LIPID PROFILE OF HERMETIA ILLUCENS FED WITH TWO DIFFERENT SEAWEEDS TO ENHANCE THEIR FATTY ACID PROFILE}

\author{
Daniela P. Rodrigues ${ }^{1,}$ Marisa Pinho ${ }^{1}$, M. $^{a}{ }^{\text {Rosário Domingues }}{ }^{2}$, Ricardo Calado ${ }^{1}$, \\ Olga M. C. C. Ameixa ${ }^{1}$ \\ ${ }^{1}$ ECOMARE, Centre for Environmental and Marine Studies (CESAM), Department of Biology, \\ University of Aveiro, Santiago University Campus, 3810-193 Aveiro, Portugal, \\ dmprodrigues@ua.pt,marisapinho@ua.pt,rjcalado@ua.pt,olga.ameixa@ua.pt \\ ${ }^{2}$ ECOMARE, Centre for Environmental and Marine Studies (CESAM), Department of Chemistry, \\ University of Aveiro, Campus de Santiago, 3810-193 Aveiro, PORTUGAL,mrd@ua.pt
}

\begin{abstract}
It is well-known that fish meal and fish oil offer will continue to experience a shortage in supply, unable to keep up with their ever growing demand (Rana et al., 2009). The expectations of finding suitable alternatives to these key ingredients for marine aquafeeds formulations relies on finding alternative sources of polyunsaturated fatty acids (PUFA), essential to ensure marine fish and shrimp healthy development. Seaweeds are often presented as an alternative source of ingredients for fish feed formulations, aiming to make aquafeeds more sustainable. Ulva sp. and Fucus sp. are highly prolific and resilient seaweeds, found in most marine and estuarine environments worldwide. These seaweeds reveal an interesting qualitative lipid profile, as they display higher levels of n-3 PUFA than of saturated or monosaturated fatty acids (Lorenzo et al., 2017; Tabarsa et al., 2012). However, their protein content is low and mostly unsuitable for fish feeding. In July of 2017, the European Union allowed the use of insect meal in aquaculture igniting research around this topic (Lähteenmäki-Uutela et al., 2017). In this study, feeding trials were performed with Hermetia illucens where diets prepared with Ulva sp. or Fucus sp. replacing a proportion of $25 \%$ and $50 \%(\mathrm{~m} / \mathrm{m})$ of a control diet (chicken feed) were supplied to developing larvae during 2,7 or 10 days. Results evidenced an increase in the levels of PUFA after 10 days of feeding with a replacement of the control diet by $50 \%$ of algae. However, detrimental effects were also recorded on the growth and life cycle duration of H. illucens. This experiment showed that n-3 PUFA can be incorporated into the lipid pool of larvae and not only bioencapsulated as previously reported. These results suggest that larval H. illucens likely display the phenotypic plasticity to mirror the biochemical profile to its diet.
\end{abstract}

Keywords: Fish oil replacement; Seaweeds; Insect Meal; Sustainable aquaculture; Feed ingredients 
Acknowledgments: Thanks are due for the financial support to CESAM (UID/AMB/50017 - POCI-01-0145-FEDER-007638), to FCT/MCTES through national funds (PIDDAC), and the co-funding by the FEDER, within the PT2020 Partnership Agreement and Compete 2020 and to project SUShI (CENTRO-01-0145-FEDER-030818), co-funded by Centro 2020 program, Portugal 2020, European Union, through the European Regional Development Fund, through the National Science Foundation (FCT/MCTES). D.P.R. is funded by a Ph.D. grant attributed by FCT/MCTES (PD/BD/143093/2018). O.M.C.C.A. is funded by national funds $(\mathrm{OE})$, through FCT, in the scope of the framework contract foreseen in the numbers 4, 5 and 6 of article 23, of the Decree-Law 57/2016, of August 29, changed by Law 57/2017, of July 19.

\section{References:}

Lähteenmäki-Uutela, A., Grmelová, N., Hénault-Ethier, L., Deschamps, M.-H., Vandenberg, G.W., Zhao, A., Zhang, Y., Yang, B., Nemane, V., 2017. Insects as Food and Feed: Laws of the European Union, United States, Canada, Mexico, Australia, and China. Eur. Food Feed Law Rev. 12, 22-36.

Lorenzo, J.M., Agregán, R., Munekata, P.E.S., Franco, D., Carballo, J., Şahin, S., Lacomba, R., Barba, F.J., 2017. Proximate Composition and Nutritional Value of Three Macroalgae: Ascophyllum nodosum, Fucus vesiculosus and Bifurcaria bifurcata. Mar. Drugs 15, 360. https://doi.org/10.3390/md15110360

Rana, K.J., Siriwardena, S., Hasan, M.R., 2009. Impact of rising feed ingredient prices on aquafeeds and aquaculture production, FAO Fisheries and Aquaculture Technical Paper.

Tabarsa, M., Rezaei, M., Ramezanpour, Z., Waaland, J.R., 2012. Chemical compositions of the marine algae Gracilaria salicornia (Rhodophyta) and Ulva lactuca (Chlorophyta) as a potential food source. J. Sci. Food Agric. 92, 2500-2506. https://doi.org/10.1002/jsfa.5659 


\title{
EVALUATION OF ISOEUGENOL IN STUNNING/KILLING GILTHEAD SEA BREAM (Sparus aurata L.)
}

\author{
Eirini Schoina*1, Helen Miliou ${ }^{2}$ \\ ${ }^{1}$ Department of Food Science and Human Nutrition, Agricultural University of Athens, Athens, \\ GREECE. \\ eschoina@aua.gr \\ ${ }^{1,2}$ Department of Animal Science and Aquaculture, Agricultural University of Athens, Athens, \\ GREECE. \\ elenmi@aua.gr
}

\begin{abstract}
Pre-slaughter and killing procedures play a significant role in fish farming management as they affect both welfare and quality of the final product. Anaesthetization of fish before slaughter is considered to improve both aspects. The aim of this study was to evaluate isoeugenol as an anaesthetic in gilthead sea bream, by using the commercial product AQUI-S ${ }^{\circledR}$, a fish anaesthetic approved for use in several countries including Australia, Chile and New Zealand.

Sixty adult gilthead sea bream of mean weight $334 \pm 46 \mathrm{~g}$ were equally distributed in 6 aquaria, part of an experimental recirculated aquaculture system. Fish were acclimated for ten days and were fed daily with a commercial pellet diet until satiation. Water quality parameters were monitored daily to ensure optimal rearing conditions. The slaughter method of immersion in ice/water slurry was compared to the method of anaesthetizing fish first by exposing them to three concentrations of AQUI-S ${ }^{\circledR}(30,50$ and $70 \mathrm{ppm})$ for a predetermined exposure time, before immersion in ice/water slurry. Haematocrit and plasma glucose were evaluated as stress indicators and muscle $\mathrm{pH}$ as a flesh quality indicator.

Haematocrit value was not elevated among any procedure, while plasma glucose in fish directly immersed in ice/water slurry remained at lower level in contrast with fish exposed to anaesthetic. Fish exposed to 30ppm AQUI-S ${ }^{\circledR}$ showed the highest plasma glucose levels. Muscle pH two hours post mortem was higher in fish exposed to the anaesthetic agent, regardless of the concentration, than in fish directly immersed in ice/water slurry, ensuring better flesh quality.
\end{abstract}

Key words: isoeugenol, gilthead seabream, rested harvesting, flesh quality, welfare 


\title{
SEA ANEMONE (ANEMONIA VIRIDIS) MICROBIOME CHARACTERIZATION ACROSS SEASONALITY IN THE NORTH ADRIATIC SEA
}

\author{
Giorgia Palladino*1, Elena Biagi ${ }^{1}$, Margherita Musella ${ }^{1}$, Gian Marco Luna ${ }^{2}$ and \\ Marco Candela ${ }^{1}$ \\ ${ }^{1}$ HolobioME (Unit of Holobiont Microbiome and Microbiome Engineering), Department of \\ Pharmacy and Biotechnology, University of Bologna, ITALY. \\ ${ }^{2}$ Institute for Marine Biological Resources and Biotechnology, National Research Council (IRBIM- \\ CNR), Ancona, Italy \\ giorgia.palladino2@unibo.it,elena.biagi@unibo.it,margherita.musella2@unibo.it, \\ gianmarco.luna@cnr.it,marco.candela@unibo.it
}

\begin{abstract}
The Adriatic Sea is a shallow semi-enclosed basin which Northern part belongs to one of the most productive regions of the Mediterranean Sea. It is subject to significant industrial activity and river discharge [1], thus it is an ideal field lab to study the impact of anthropogenic stress factors on marine habitats. In particular, Riccione (Italy) is a heavily exploited touristic site, which results in a human-derived pollution gradient increasing from winter to summer (Arpae - ER, www.arpae.it). In this study we characterised the microbiome composition and variation across seasonality of 20 individuals of the snakelocks anemone Anemonia viridis, an important model species to study the response and adaptation of symbiotic Cnidaria to environmental stress [2]. Anemone individuals were collected in shallow water $(<10 \mathrm{~m})$ on Riccione shore, in the North Adriatic Sea, in 3 different seasons - winter (February 2019), spring (May 2019) and summer (July 2019) - and their microbiome composition was investigated by sequencing of the V3-V4 region of the $16 \mathrm{~S}$ rRNA gene.

Overall, the microbial composition of $A$. viridis is dominated by the phyla Proteobacteria, Bacteroidetes and Firmicutes, which resembles other Cnidaria microbial composition $[3,4]$. However, at a lower taxonomic level, A. viridis microbiome has a highly variable ecological structure when comparing different collection times, with anemone microbiota showing a strong separation among seasons. In particular, Flavobacteriaceae, Planctomycetaceae, Psychromonadaceae, Rhodobacteraceae, Saprospiraceae and Thiotrichaceae families leads the separation of winter microbiome. Campylobacteraceae, family XII of Clostridiales, Fusobacteriaceae, Pseudoalteromonadaceae and Shewanellaceae characterise instead the spring microbiome. Lastly, Oceanospirillaceae are the main responsible for summer microbiome separation.
\end{abstract}


Our findings may suggest the adaptability of $A$. viridis microbiome to seasonal changes. However, further investigation is still being performed in order to understand the role of the different microbial composition on the host physiology and its adaptation to environmental changes.

Key words: snakelocks anemone; 16s rRNA amplicon sequencing; seasonal microbiome; microbiome-environment interactions.

\section{Acknowledgments}

This work was supported by the "Controlling Microbiomes Circulations for Better Food Systems" (CIRCLES) project, funded by the European Union's Horizon 2020 research and innovation program under grant agreement no. 818290. We would like to thank the Cooperativa Bagnini Riccione (Rimini, Italy), Associazione BLENNIUS (Rimini, Italy) and Fondazione Cetacea Onlus (Rimini, Italy) for their primary contribution to the samples collection. We would also like to thank Gianni Fiori - Yacht Club Viserba (Rimini, Italy) for his support in the transport of the samples.

\section{References}

[1] Zoppini, A., Ademollo, N., Patrolecco, L., Langone, L., Lungarini, S., Dellisanti, W., \& Amalfitano, S. (2018). Distribution patterns of organic pollutants and microbial processes in marine sediments across a gradient of anthropogenic impact. Environmental Pollution, 242, 1860-1870.

[2] Mallien, C., Porro, B., Zamoum, T., Olivier, C., Wiedenmann, J., Furla, P., \& Forcioli, D. (2018). Conspicuous morphological differentiation without speciation in Anemonia viridis (Cnidaria, Actiniaria). Systematics and Biodiversity, 16(3), 271-286.

[3] Har, J. Y., Helbig, T., Lim, J. H., Fernando, S. C., Penn, K., Reitzel, A. M., \& Thompson, J. R. (2015). Microbial diversity and activity in the Nematostella vectensis holobiont: insights from 16S rRNA gene sequencing, isolate genomes, and a pilot-scale survey of gene expression. Frontiers in microbiology, 6 , 818.

[4] Muller, E. M., Fine, M., \& Ritchie, K. B. (2016). The stable microbiome of inter and sub-tidal anemone species under increasing pCO 2. Scientific reports, 6, 37387. 


\title{
RED SEAWEEDS Grateloupia turuturu AND Porphyra umbilicalis AS A MARINE RESOURCE - A STUDY ON THE PHENOLIC COMPOSITION AND BIOACTIVE PROPERTIES
}

\author{
João M. Ferreira* ${ }^{1,2}$, Carlos Martins-Gomes ${ }^{1,3}$, Fernando M. Nunes ${ }^{4}$, Mário \\ Pacheco $^{5}$, Isabel Gaivão ${ }^{2,6}$ and Amélia M. Silva ${ }^{1,3}$ \\ ${ }^{1}$ Department of Biology and Environment (DeBA), University of Trás-os-Montes and Alto Douro \\ (UTAD), Vila Real, PORTUGAL. \\ joaommf93@hotmail.com,camgomes@utad.pt,amsilva@utad.pt \\ 2 Animal and Veterinary Research Centre (CECAV), UTAD, Vila Real, PORTUGAL. \\ ${ }^{3}$ Centre for Research and Technology of Agro-Environmental and Biological Sciences (CITAB), \\ UTAD, Vila Real, PORTUGAL. \\ ${ }^{4}$ Chemistry Center-Vila Real (CQ-VR) and Department of Chemistry (DQ-ECVA), UTAD, Vila \\ Real, PORTUGAL. \\ fnunes@utad.pt \\ ${ }^{5}$ Centre for Environmental and Marine Studies (CESAM) and Department of Biology (dbio), \\ University of Aveiro (UA), Aveiro, PORTUGAL. \\ mpacheco@ua.pt \\ ${ }^{6}$ Department of Genetics and Biotechnology (DGB), UTAD, Vila Real, PORTUGAL. \\ igaivao@utad.pt
}

\begin{abstract}
Seaweeds, or marine macroalgae, are currently being explored for several applications (including food, agriculture, biofiltering, biofuel). Their use as a marine resource in Europe is low in comparison to East Asia, especially for human consumption. There is a great biodiversity of species present on the European coast with underexplored health benefits. Thus, we studied the phenolic composition and antioxidant, antiproliferative and anti-inflammatory activities of the red seaweeds Grateloupia turuturu and Porphyra umbilicalis, aiming to promote their exploration and use as a natural food resource. Firstly, hydroethanolic and aqueous (infusion and decoction) extracts of $G$. turuturu and P. umbilicalis were prepared. Their content in total phenols, ortho-diphenols and flavonoids, as well as their antioxidant potentials (against $\mathrm{ABTS}^{\circ+},{ }^{\circ} \mathrm{OH}$ and $\mathrm{NO}^{\circ}$ radicals) were evaluated by colorimetric methods. High-performance liquid chromatography (HPLC) was used for phenolic characterization. The anti-proliferative activity (against RAW 264.7 cells, a murine macrophage cell line) was assessed by the alamarBlue ${ }^{\circledR}$ assay and, for the anti-inflammatory activity (using lipopolysaccharide stimulated RAW 264.7 cells), the Griess method was followed. The total phenols and ortho-diphenols contents were higher for the aqueous extracts of both species. However, residual flavonoids contents were exhibited by all extracts. The aqueous extracts demonstrated the greatest $\mathrm{ABTS}^{\cdot+}$ and $\mathrm{NO}^{*}$ (greater for G. turuturu) scavenging activities; the hydroethanolic extracts led to the most accentuated antioxidant properties against ${ }^{\circ} \mathrm{OH}$. The anti-proliferative activity showed a positive correlation with extracts concentration
\end{abstract}


and exposure time, with the greatest potential being displayed by the $P$. umbilicalis aqueous extracts. The $P$. umbilicalis hydroethanolic extract showed the highest antiinflammatory activity, followed by the G. turuturu aqueous extracts. Overall, G. turuturu and $P$. umbilicalis showed their potential as a natural food product. As such, their sustainable harvest and aquaculture production should be further focused in Europe for nutritional and nutraceutical applications.

Key words: Marine macroalgae, Antioxidant, Anti-proliferative, Anti-inflammatory

Acknowledgments: European Investment Funds by FEDER/COMPETE/POCI under Projects POCI-01-0145-FEDER-006958 (CITAB), POCI-01-0145-FEDER-007728 (CQVR) and POCI-01-0145-FEDER-007638 (CESAM), and Funds from FCT, to CITAB (UID/AGR/04033/2019), CQ-VR (PEst-OE/QUI/UI0616/2014), CECAV (UID/CVT/00772/2019) and CESAM (UID/AMB/50017). FCT grants to JMF (SFRH/BD/144882/2019), and to CMG (SFRH/BD/145855/2019). The authors would like to thank ALGAplus Company for the harvest and identification of the seaweed species.

\section{References:}

FAO (2018). The global status of seaweed production, trade and utilization. Globefish Research Programme, 124 , Rome, $120 \mathrm{pp}$.

Ferreira, J., Marques, A., Abreu, M.H., Pereira, R., Rego, A., Pacheco, M., and Gaivão, I. (2019). Red seaweeds Porphyra umbilicalis and Grateloupia turuturu display antigenotoxic and longevitypromoting potential in Drosophila melanogaster. European Journal of Phycology, 54 (4), 519-530.

Martins-Gomes, C., Taghouti, M., Schäfer, J., Bunzel, M., Silva, A.M., and Nunes, F.M. (2018). Chemical characterization and bioactive properties of decoctions and hydroethanolic extracts of Thymus carnosus Boiss. Journal of Functional Foods, 43, 154-164.

Queiroz, M., Oppolzer, D., Gouvinhas, I., Silva, A.M., Barros, A., and Domínguez-Perles, R. (2017). New grape stems' isolated phenolic compounds modulate reactive oxygen species, glutathione, and lipid peroxidation in vitro: Combined formulations with vitamins C and E. Fitoterapia, 120, 146-157. 


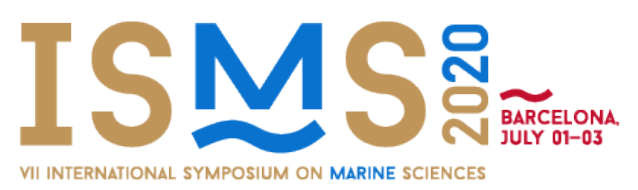

VII International Symposium on Marine Sciences

ISMS 2020

Barcelona (Spain), $1^{\text {st }}-3^{\text {rd }}$ July 2020

\section{DECODING SPONGE RESPONSES TO A DYNAMIC ENVIRONMENT BY RNA-SEQ}

\author{
Lucía Pita*¹, Yu-Chen Wu ${ }^{1,2}$, Marc Höppner ${ }^{3}$, Sören Franzenburg ${ }^{3}$, Marta Ribes ${ }^{4}$ \\ and Ute Hentschel ${ }^{1,2}$ \\ ${ }^{1}$ Marine Ecology, GEOMAR Helmholtz Centre for Ocean Research, Kiel, GERMANY. \\ ${ }^{2}$ Christian-Albrechts University, Kiel, GERMANY \\ lpita@geomar.de,yuchen.wu.m@gmail.com,uhentschel@geomar.de \\ ${ }^{3}$ Institute of Clinical Molecular Biology, Christian-Albrechts University, Kiel, GERMANY \\ m.hoeppner@ikmb.uni-kiel.de,s.franzenburg@ikmb.uni-kiel.de \\ ${ }^{4}$ Institute of Marine Science, Barcelona, SPAIN \\ mribes@geomar.de
}

Marine sessile animals live attached to a substrate but face the challenge of a changing environment. They need to avoid microbial infections, competitors for space, fouling or grazing. And all these biotic challenges add to the abiotic pressures such as warming or eutrophication. In looking for the underlying molecular mechanisms for successfully respond and remain healthy in a dynamic environment, the immune system is emerging as the guardian of homeostasis and animal-microbe interactions (Palmer, 2018). Sponges (phylum Porifera) are early-diverging animals, providing a valuable evolutionary perspective into conserved mechanisms, and they are also key players in benthic ecosystems. Sponges feed on seawater bacteria by filtering thousands of liters of water per day; yet, they harbour complex species-specific microbial communities and, together, deeply impact the benthic-pelagic coupling (Pita et al., 2018b). We aim to characterize the role of sponge immunity in maintaining organism health and function. For this, we applied experimental approaches in combination with RNA-Seq to identify candidate key genes/pathways in sponge homeostasis. We addressed the response of the Mediterranean sponge $A$. aerophoba to (i) microbial stimuli (i.e. exposure to LPS and peptidoglycan $v s$ sterile artificial seawater), (ii) microbes (exposure to symbiont-enriched fraction $v s$ bacterioplankton), and (iii) grazing. We found that the receptors of the families SRCRs and GPCRs mediated sponge responses. The response to microbes involved the activation of apoptotic pathways, genes related with extracellular matrix and vesicular-mediated transport, and the down-regulation of serine threonine protein kinases and lipid metabolism (Pita et al., 2018a). Wounding activated the complement system, calcium signaling, and transcription factors such as Ets. Our results enable to address the network of genes involved in sponge immune repertoire based on experimental data. This makes up the first step towards understanding the mechanisms of homeostasis in the sponge holobiont and the conserved immunological repertoire in animals.

Key words: immunity, holobiont, microbe, grazing, RNA-Seq 
Acknowledgments: LP was awarded a postdoctoral fellowship from Alexander von Humboldt Foundation, which was sponsored by The Future Ocean Cluster of Excellence. $\mathrm{MR}$ is a member of the Marine Biogeochemistry and Global Change research group from the "Generalitat de Catalunya". UH received financial support from the DFG (CRC1182TPB1).

References: please follow the examples below

Palmer, C. V. (2018). Immunity and the coral crisis. Commun. Biol. 1, 91. doi:10.1038/s42003-018-0097-4.

Pita, L., Hoeppner, M. P., Ribes, M., and Hentschel, U. (2018a). Differential expression of immune receptors in two marine sponges upon exposure to microbial- associated molecular patterns. Sci. Rep. 8, 16081. doi:10.1038/s41598-018-34330-w.

Pita, L., Rix, L., Slaby, B. M., Franke, A., and Hentschel, U. (2018b). The sponge holobiont in a changing ocean: from microbes to ecosystems. Microbiome 6, 46. doi:10.1186/s40168-018-0428-1. 


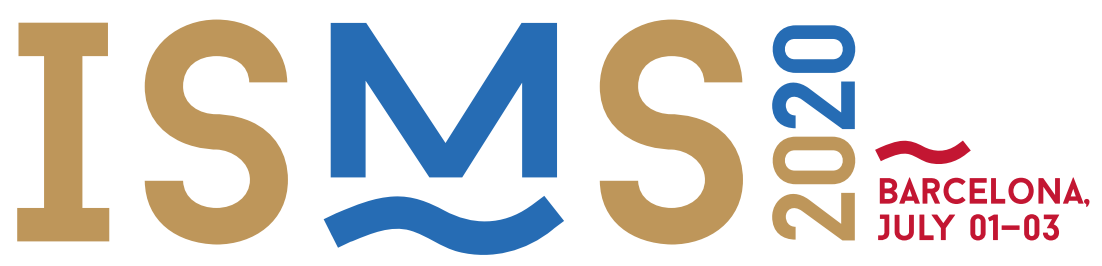

VII INTERNATIONAL SYMPOSIUM ON MARINE SCIENCES BARCELONA
JULY 01-03

ORAL COMMUNICATIONS

\section{POLAR MARINE RESEARCH}




\title{
PROPERTY BALANCES IN THE SCOTIA SEA AS DEDUCED FROM INVERSE MODELLING
}

\author{
A. Olivé Abelló $* 1$, J.L. Pelegrí ${ }^{2}$ and F. Machín ${ }^{3}$ \\ ${ }^{1,2}$ Department of Physical and Technological Oceanography, Institut de Ciències del Mar, CSIC, Barcelona, SPAIN. \\ aolive@icm.csic.es,pelegri@icm.csic.es \\ ${ }^{3}$ Physics Department, Universidad de Las Palmas de Gran Canaria, Las Palmas de Gran Canaria, SPAIN. \\ francisco.machin@ulpgc.es
}

\begin{abstract}
An inverse model (Machín et al., 2006; Wunsch, 1996) is applied to the Scotia Sea (Naveira Garabato et al., 2003) in order to assess the balances of heat, salt, mass and biogeochemical properties in the upper $2000 \mathrm{~m}$ of the Antarctic Circumpolar Current (ACC). The circulation model is constructed using hydrographic profiles at the boundaries of the region as obtained from several datasets: SODB (Orsi \& Whitworth, 1998), MEOP (Roquet et al., 2014), ESASSI and Argo. The reference velocities at $1000 \mathrm{~m}$ are calculated from the drifting of the Argo floats and conditioned with the freshwater fluxes and wind-driven Ekman transports. The model results reveal that the upper Scotia Sea circulation pattern consists mainly of water inputs in the Drake, Phillip and South Scotia Ridge Passages, and outputs through the North Scotia Ridge and Georgia Passages, dominated by the circumpolar deep waters. The ACC mass transports through the different passages are as follows: $154.5 \pm 1.6 \mathrm{~Sv}$ for the Drake, $105.8 \pm 1.4 \mathrm{~Sv}$ for the North Sotia Ridge, $53.9 \pm 1 \mathrm{~Sv}$ for

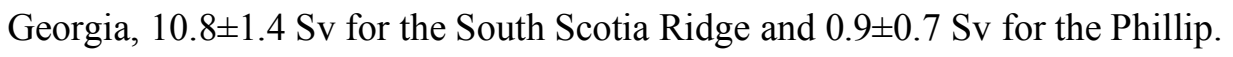

Moreover, the Biogeochemical Southern Ocean State Estimate (B-SOSE) (Verdy \& Mazloff, 2017) is used for establishing the dissolved oxygen, nitrate and phosphate concentrations at the boundaries. The fluxes of these properties are hence obtained as the product of velocity times concentration. Using this methodology, the inverse model shows fairly good biogeochemical balances, with total transport inputs of $37021 \mathrm{kmol} \mathrm{s}^{-1}$ for dissolved oxygen, $5007 \mathrm{kmol} \mathrm{s}^{-1}$ for nitrates and $349 \mathrm{kmol} \mathrm{s}^{-1}$ for phosphates, and output transports through the remaining passages of $35779 \mathrm{kmol} \mathrm{s}^{-1}, 4804 \mathrm{kmol} \mathrm{s}^{-1}$ and $333 \mathrm{kmol} \mathrm{s}^{-1}$, respectively.
\end{abstract}

Key words: Scotia Sea, mass balance, inverse model.

Acknowledgements: This work has been supported by project SAGA (RTI2018-100844-B-C33), funded by the Spanish government. AOA is grateful to the Ministerio de Ciencia, Innovación y Universidades for a formation contract (FPU17/03796) and to the Universitat de Barcelona and Universidad de Las Palmas de Gran Canaria for their support during an internship that helped to implement the inverse model.

\section{References:}

Machín, F., Hernández-Guerra, A., \& Pelegrí, J. L. (2006). Mass fluxes in the Canary Basin. Progress in Oceanography, $70(2-4), 416-447$.

Naveira Garabato, A. C., Stevens, D. P., \& Heywood, K. J. (2003). Water mass conversion, fluxes, and mixing in the Scotia Sea diagnosed by an inverse model. Journal of Physical Oceanography, 33, 2565-2587.

Orsi, A. H., \& Whitworth III, T. (2005). Hydrographic Atlas of the World Ocean Circulation Experiment (WOCE) Volume 1: Southern Ocean. M. Sparrow, P. Chapman \& J.Gould, Eds., International WOCE Project Office, 223. 
Roquet, F., Williams, G., Hindell, M. A., et al. (2014). A Southern Indian Ocean database of hydrographic profiles obtained with instrumented elephant seals. Scientific Data, 1, 140028.

Verdy, A., \& Mazloff, M. R. (2017). A data assimilating model for estimating Southern Ocean biogeochemistry. Journal of Geophysical Research: Oceans, 122, 6968-6988.

Wunsch, C. (1996). The Ocean Circulation Inverse Problem. Cambridge University Press, Cambridge, 212-296. 


\title{
ASSESSMENT OF THE CORRELATION BETWEEN RIVER DISCHARGE AND SEA ICE GROWING IN LAPTEV SEA
}

\author{
C. Gabarrón ${ }^{*}$, J. Martínez ${ }^{1}$, M. Umbert ${ }^{1}$, C. González-Haro ${ }^{1}$, E. Olmedo ${ }^{1,}$ \\ Gonzalez-Gambau $^{1}$, A. Turiel ${ }^{1}$, L. Bertino ${ }^{2}$, J. Xie ${ }^{2}$, R. P. Raj ${ }^{2}$, R. Catany ${ }^{3}$, M. \\ Arias $^{3}$, R. Sabia ${ }^{4}$ and D. Fernández ${ }^{5}$ \\ ${ }^{1}$ Barcelona Expert Center, Institute of Marine Science- CSIC, Barcelona, SPAIN. \\ cgabarro@icm.csic.es, justino@icm.csic.es, mumbert@icm.csic.es, cgharo@gmail.com, \\ olmedo@icm.csic.es,vgonzalez@cmima.csic.es,turiel@icm.csic.es \\ ${ }^{2}$ Nansen Environmental and Remote Sensing Center, Bergen, NORWAY. \\ laurent.bertino@nersc.no,Jiping.Xie@nersc.no,Roshin.Raj@nersc.no \\ ${ }^{3}$ Argans Ltd., Plymouth, UNITED KINDOM. \\ Rcatany@argans.co.uk,MArias@argans.co.uk \\ ${ }^{4}$ Telespazio-Vega for European Space Agency, Frascati, ITALY. \\ roberto.sabia@esa.int \\ ${ }^{5}$ European Space Agency, Frascati, ITALY \\ Diego.Fernandez@esa.int
}

\begin{abstract}
During the last 3 decades, the Arctic rivers have increased its discharge around $10 \%$ mainly due the increase of temperature (Rawlins et al., 2010). The larger river discharge carries higher loads of dissolved organic matter (DOM) and suspended matter (SM) entering the Arctic Ocean. These results in increased absorption of solar energy in the mixed layer potentially contributing to the general sea ice retreat (Soppa et al. 2019). Bauch et al., 2013 observed a correlation between river water discharge and local sea ice melting on the Laptev sea shelf, based on in-situ measurements, due to the change on the heat.

New Arctic sea surface salinity products obtained from the ESA satellite SMOS (Soil Moisture and Ocean Salinity) have been improved considerable thanks to the ESA funded project Arctic+ Salinity. The maps have better accuracy and resolution so the salinity fronts are better resolved. These improved maps will permit for the first time to study scientific processes that have never been described up to now with satellite data. We will explore if a correlation between the Lena and $\mathrm{Ob}$ rivers discharge with the sea ice melting and freeze up is observed with satellite data, manly with the 9 years of SMOS data. Salinity and sea ice thickness maps from SMOS and sea ice concentration from AMSR2 satellite will be used in this study.
\end{abstract}


Key words: Arctic, Sea surface salinity, Climate change, Remote sensing

Acknowledgments: Thanks to ESA for funding the Arctic+ Salinity Project.

\section{References:}

Bauch, D., Hölemann, J. A., Nikulina, A., Wegner, C., Janout, M. A., Timokhov, L. A., and Kassens, H. (2013), Correlation of river water and local sea ice melting on the Laptev Sea shelf (Siberian Arctic), J. Geophys. Res. Oceans, 118, 550- 561, doi:10.1002/jgrc.20076.

Rawlins, M. A, et al., (2010). Analysis of the Arctic System for Freshwater Cycle Intensification: Observations and Expectations, Journal of Climate 23(21) .

Soppa MA, Pefanis V, Hellmann S, Losa SN, Hölemann J, Martynov F, Heim B, Janout MA, Dinter T, Rozanov V and Bracher A (2019) Assessing the Influence of Water Constituents on the Radiative Heating of Laptev Sea Shelf Waters. Front. Mar. Sci. 6:221. doi: 10.3389/fmars.2019.00221.Bauch, D., Hölemann, J. A., Nikulina, A., Wegner, C., Janout, M. A., Timokhov, L. A., and Kassens, H. (2013), Correlation of river water and local sea ice melting on the Laptev Sea shelf (Siberian Arctic), J. Geophys. Res. Oceans, 118, 550- 561, doi:10.1002/jgrc.20076. 


\title{
MODELING THE DOWNSLOPE PROPAGATION OF DENSE SHELF WATER FLOWS IN ANTARCTICA
}

\author{
D. Amblas ${ }^{* 1}$, R.S. Jacinto ${ }^{2}$ and T.P. Gerber ${ }^{3}$ \\ ${ }^{1}$ CRG Marine Geosciences, Department of Earth and Ocean Dynamics, University of Barcelona, \\ Barcelona, Catalonia, SPAIN. \\ damblas@ub.edu \\ ${ }^{2}$ Marine Geosciences Unit, French National Institute for Sea Research and Exploration, IFREMER, \\ Plouzané, FRANCE. \\ ricardo.silva.jacinto@ifremer.fr \\ ${ }^{3}$ Statoil - Research and Technology, Austin, Texas, USA \\ tpgerber@gmail.com
}

\begin{abstract}
Multiple mechanisms work together to increase the ocean surface waters density to the point that these can sink to abyssal depths. In temperate margins cold and dry winds are the responsible to cool down the continental shelves surface waters and to increase evaporation rates and, thus, the water density. In high-latitudes cold winds are even able to freeze the ocean surface and produce sea-ice that forces out the salt. Once denser than surrounding waters, the cold and salty water sinks to the seafloor, overflows the shelf edge and cascades downslope just as rivers on land flow downhill towards the sea. This important oceanographic process is called dense shelf-water cascading (DSWC). During the last decades we have observed a progressive weakening of dense shelf water formation and export (Amblas and Dowdeswell, 2018), which reflects the variability of these complex iceocean systems and their vulnerability to climate change. Within this fragile context it is necessary to understand the physical processes involved in the concentration and propagation of DSWC.
\end{abstract}

We tackle this question using a process-based depth-integrated numerical model, which was initially developed for turbidity currents (Nixes-Tc model, developed at IFREMER, Jacinto and Burel, 2003). Our modelling analysis, based on Antarctica field observations, show the importance of flow confinement features (i.e. coast capes, cross-shelf troughs, canyons and gullies) to concentrate and propagate dense shelf water and, ultimately, to renew the oceans deep water. We also study the capacity of individual DSWC events to transport sediment, and provide insight into the cumulative effect of repeated DSWC events in shaping the seafloor. In this presentation we will show different model runs using a set of flow parameters, boundary conditions and generic terrain models that allows us to discuss also on the differences in erosion and sediment transport capacity between DSWC and turbidity currents.

Key words: Dense shelf water flows, Antarctica, Modelling, Hydrodynamics, Sedimentology

Acknowledgments: This project has received funding from the European Union's Horizon 
2020 research and innovation programme under Marie Sklodowska-Curie grant agreement No. 658358, and also from a postdoctoral grant of the International Association of Sedimentologists (IAS).

\section{References:}

Amblas, D. and Dowdeswell, J.A. (2018). Physiographic influences on dense shelf-water cascading down the Antarctic continental slope. Earth-Science Reviews 185, 887-900.

Jacinto, R.S. and Burel, D. (2003). Modélisation du devenir à court terme des boues de dragage rejetées par clapage. Revue Française de Génie Civil 7, 1151-1166. 


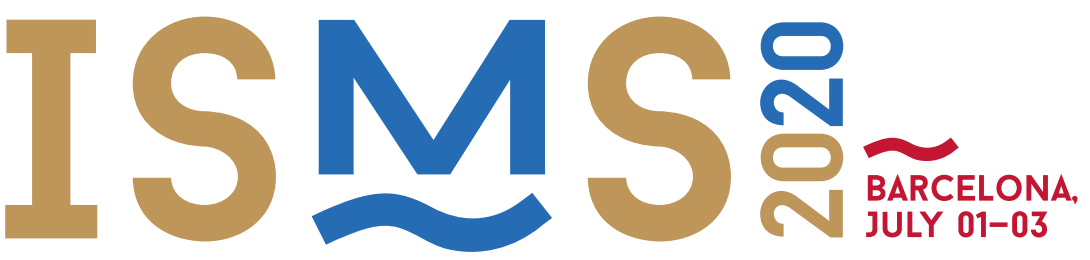

VII INTERNATIONAL SYMPOSIUM ON MARINE SCIENCES

\section{ORAL \\ COMMUNICATIONS}

SOCIAL SCIENCES,

MUSEUMS

AND OUTREACH

IN MARINE SCIENCES 


\title{
ICHTHYOFAUNA OF THE BAJA CALIFORNIA PENINSULA DEPICTED ON THE ROCK PAINTINGS OF SIERRA DE SAN FRANCISCO AND SIERRA DE GUADALUPE, MEXICO
}

\author{
Gutiérrez-Martínez, María de la Luz ${ }^{*}$, Aceves-Medina, Gerardo ${ }^{2}$ and Álvarez- \\ Ramírez, Indra María ${ }^{3}$ \\ ${ }^{1}$ Instituto Nacional de Antropología e Historia, Baja California Sur, MÉXICO. \\ lukerotres@gmail.com, \\ ${ }^{2,3}$ Instituto Politécnico Nacional, CICIMAR, La Paz, MÉXICO. \\ gaceves@ipn.mx; indra.alvarez@gmail.com
}

\begin{abstract}
The San Francisco and Guadalupe Sierras (Central Baja California, Mexico), concentrate a huge number of sites of the Grand Mural pictorial tradition. Panels painted approximately between 3,500 and 5,500 years ago, exhibit an interesting diversity of terrestrial and marine fauna (Gutiérrez-Martínez 2013; Rector, 1981). A large part of these sites consist of fish depictions, some roughly designed, but with morphological characteristics that in many cases, allow their identification at least at the family or genus taxonomic levels. Exceptionally, we can find a few paintings very well delineated that the researcher can be able to give an approximate determination to the species level. In this research, we present the identification results of the marine fish representations found in 14 rock-painting sites. Fish drawings correspond at least to 37 morpho-types, from which 17 seem to belong to 11 orders and 15 families. Only 10 fish forms were assigned to a possible genus and five to a possible species. Paintings of sharks, rays, morays, groupers, jack mackerels, pompano, tunas and flounders are between the most conspicuous fish depictions. Identification of the painted organisms will allow us to gradually obtain a catalog, which will help infer the extraction sites of these fish (Gulf of California or the West Coast of the Peninsula of Baja California) and will be useful to understand mobility patterns and subsistence of hunter-gatherer-fishermen groups that lived in these mountains.
\end{abstract}

Key words: Rock paintings, fish fauna, Baja California, archaeological fish records

Acknowledgments: To INAH and CONACYT for the financing of projects for the exploration of archeological sites.

References: please follow the examples below

Gutiérrez-Martínez, M.L. 2013. Paisajes ancestrales. Identidad, memoria y arte rupestre en las cordilleras centrales de la Península de Baja California. Tesis doctoral, Escuela Nacional de Antropología e Historia, México

Rector, C.H. (1981). Fish depictions in central Baja California rock art. Pacific Coast Archaeological Society Quarterly, 17 (1), 17-23. 


\title{
MOTIVATIONS AND CONCERNS OF EARLY CAREER MARINE RESEARCHERS
}

\author{
Tania Montoto-Martínez*1, OYSTER Euromarine Working Group2 \\ ${ }^{1}$ Environmental Technologies, Management and Biogeochemistry research group, University of \\ Las Palmas de Gran Canaria, Canary Islands, SPAIN. \\ tania.montoto@ulpgc.es \\ ${ }^{2}$ Orienting Young Scientists of Euromarine, Euromarine, International Network \\ oyster@euromarinenetwork.eu
}

\begin{abstract}
:
EuroMarine is an organisation that promotes bottom-up science from the marine science community. The "Orienting Young Scientist of EuroMarine (OYSTER)" group was formed in early 2018 to engage with young scientists and soon expanded to include a forum of $23 \mathrm{PhDs}$ and post-docs from institutions located through 11 countries.

OYSTER aims to (i) engage with and represent early career scientists (ECS) within the EuroMarine network, (ii) contribute towards the cohesive outreach and capacity building of ECS, and (iii) develop initiatives to support and integrate ECS within the European marine landscape. In 2018, OYSTER ran a survey which was distributed to institutions across Europe, to develop advice in matters pertaining to the support and development of ECS.

We received responses from 462 scientists and, even though, overall feedback concerning early career scientist work and life was positive, some findings from the survey deserve to be given some consideration and require attention by scientific institutions. Around one in five respondents feel that they are not being fairly treated in their workplace. Also, almost $75 \%$ of respondents do things that are outside of their responsibilities from which less than half don't mind doing it. Further, the majority of respondents are employed on short 1-3 year contracts, which may also have large impacts on job stability and work-life balance which can lead towards increased work stress and the leakage of young scientist from academia.
\end{abstract}

The feedback collected from this survey gives insight into current issues concerning young scientist. In view of this situation, OYSTER plans to continue their efforts to raise awareness about the concerns of ECS and support them through skill-sharing events and an online mentorship platform, both of them recommended initiatives in previous studies on the matter $[1,2]$. 
Key words: EuroMarine, OYSTER, Early Career Scientists (ECS), survey, mentorship.

\section{References:}

1. Geffers J, Beaudry C, Yang H-C, Huang F, et al. Global State of Young Scientists [GloSYS] in ASEAN. Halle, Germany: Global Young Academy; 2017 p. 100.

2. Lee A, Dennis C, Campbell P. Nature 's guide for mentors. Nature. 2007;447: 791-797. doi:10.1038/447791a 


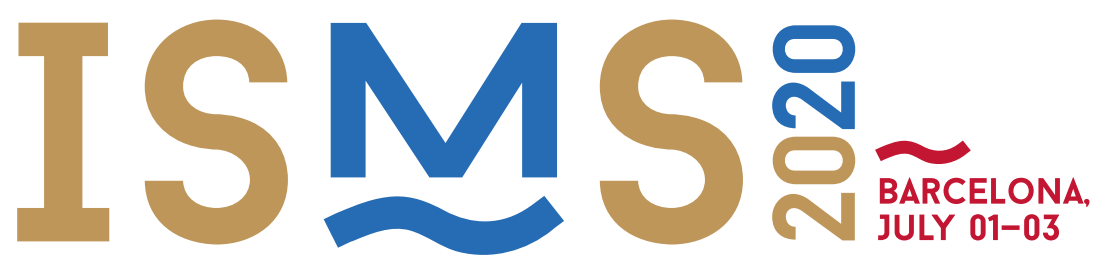

VII INTERNATIONAL SYMPOSIUM ON MARINE SCIENCES BARCELONA
JULY 01-03

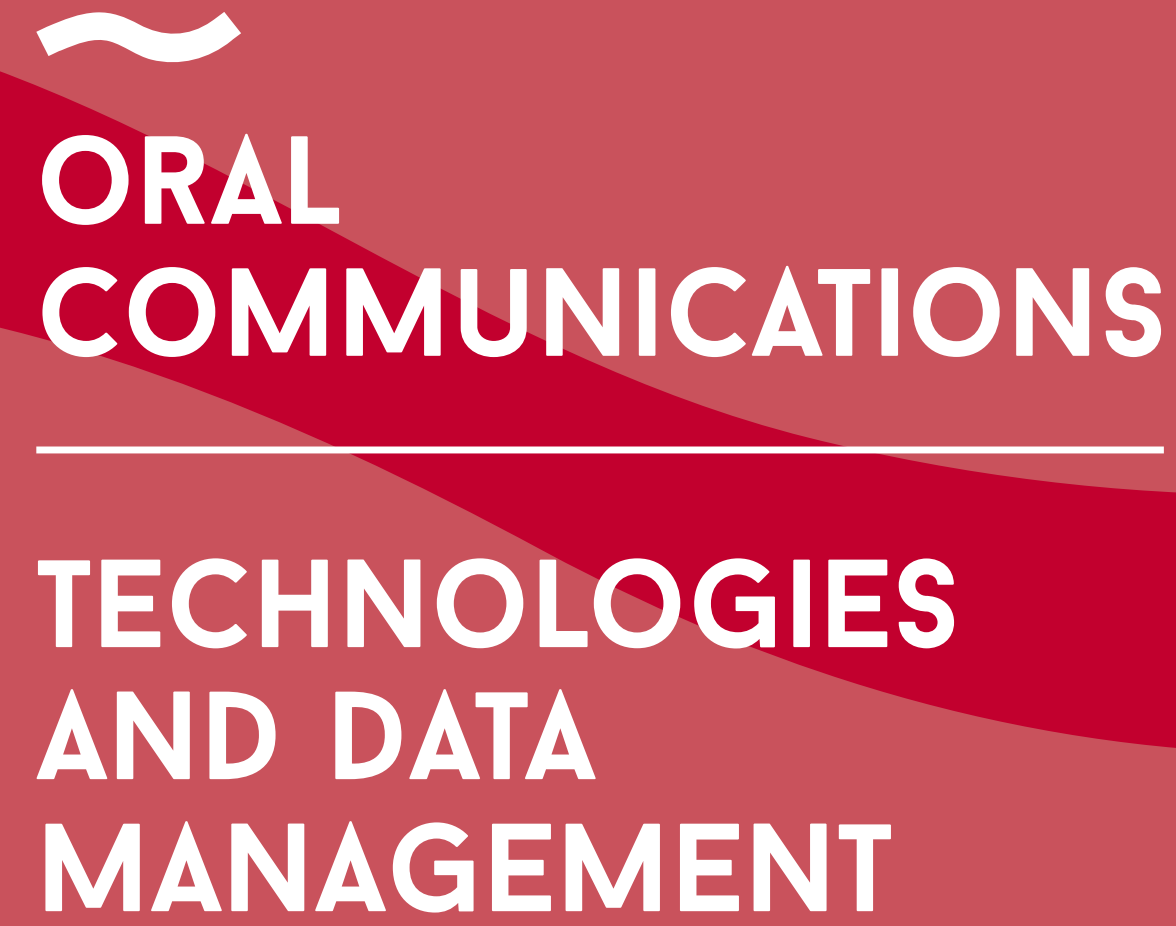

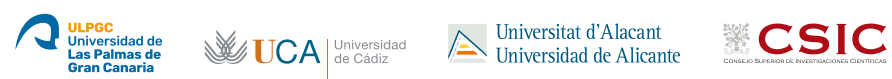




\title{
DOWNSCALING OF WRF1,3 MODEL OUTPUT IN THE RIA DE VIGO
}

\author{
Fernández Baladrón A.*¹, Herrera, J.L. ${ }^{1}$ and Varela, RA ${ }^{1}$ \\ ${ }^{1}$ Grupo de Oceanografía Física GOFUVI, Universidad de Vigo, España. \\ adrianfernandez@alumnos.uvigo.es, juan.luis.herrera.cortijo@gmail.com,rvarela@uvigo.es
}

\begin{abstract}
In this work, we use different interpolation approaches to enhance the spatial resolution of wind maps from Meteogalicia's WRF1,3 km model. We compare the results and performances of four interpolation methods in the Ría de Vigo.

Wind drag is a key driver of ocean surface dynamics in the Ría de Vigo (Varela et al., 2005). It has a definite impact on many aspects of the Ría's vibrant economy like aquaculture, navigation safety, nautical activities, and pollutant dispersion. Thus, wind prediction models are excellent tools for the management of the Ría's environment. However, their current spatial resolution may not be suitable for some purposes.
\end{abstract}

Meteogalicia provided wind maps from their WRF 1,3 $\mathrm{km}$ wind model. We brought the resolution up to $1 \mathrm{~km}$., $500 \mathrm{~m}$., and $100 \mathrm{~m}$. For that, we applied a set of conventional interpolation approaches to each map: inverse distance weighting, ordinary kriging, and co-kriging (Reinhardt et al. 2017). Also, as the Ría's orography channels the wind (Herrera et al. 2005), we tested regression-kriging with integrated topography. Finally, we evaluated the performance of each method available wind data sources from land and/or moored wind data stations.

This study is the first step toward an operational system that enhances wind predictions at a small spatial scales in coastal areas. While the application of this methodology in other coastal areas will require further research, we hope that these results can provide significant assistance.

Key words: Winds, Downscaling, Modelling, interpolation methods, winds model.

Acknowledgments: The authors gratefully acknowledge Marcos Tesouro from Meteogalicia for providing detailed WRF model outputs, Puerto de Vigo for granting the install permission of the meteorological stations and Jose González and the crew of $\mathrm{B} / \mathrm{O}$ Kraken, from CIM-ECIMAT, for their continued support and expertise. 


\section{References:}

Herrera, J., Piedracoba, S., Varela, R., Roson, G., 2005. Spatial analysis of the wind field on the western coast of Galicia (NW Spain) from in situ measurements. Continental Shelf Research 25, 1728-1748.

Reinhardt, K., Samini, Cyrus. 2017. Comparison of different wind data interpolation methods for a region with complex terrain in Central Asia. Climate Dynamics. 51, 3635-3652.

Varela, R., Roson, G., Herrera, J., Torres-Lopez, S., Fernandez-Romero, A., 2005. A general view of the hydrographic and dynamical patterns of the Rias Baixas adjacent sea area. Journal of Marine Systems $54,97-113$. 


\title{
SENTINEL-2A/B SATELLITES FOR AQUATIC AND COASTAL SCIENCE APPLICATIONS
}

\author{
Isabel Caballero ${ }^{* 1}$ and Gabriel Navarro ${ }^{1}$ \\ ${ }^{1}$ Department of Ecology and Coastal Management, Instituto de Ciencias Marinas de Andalucía \\ (ICMAN-CSIC), Cadiz, SPAIN. \\ isabel.caballero@icman.csic.es, gabriel.navarro@icman.csic.es
}

\begin{abstract}
The European Commission is gearing up for a new era in Earth Observation with the Europe's ambitious Copernicus monitoring programme and its family of Sentinel satellites. Copernicus offers a set of key information services for a multitude of environmental applications rising to the challenges of global change and the need to manage the environment more effectively. This research looks at the Sentinel-2A/B optical twin mission. The 5-day revisit of the pair of Multi Spectral Imagers onboard Sentinel-2 with 10 $\mathrm{m}$ spatial resolution in visible bands, combined with freely available data worldwide, is unprecedented, providing new insights into the observation of nearly any coastal place on Earth. In this work, we have implemented a methodology for the atmospheric correction in order to generate accurate water reflectances using the ACOLITE processor, which is focused on coastal and inland complex water environments. We have developed the procedures for the application of this imagery to address several coastal issues such as monitoring water quality and dredging-induced turbidity over estuaries and coastal regions in Andalusia (Caballero et al., 2018a,b), detection of small harmful algal blooms (HABs) in coastal waters (Caballero et al., 2020), estimation of shallow bathymetry in USA (Caballero et al., 2019; Caballero \& Stumpf 2019, 2020), and evaluation of the flooding impact after the Cold Drop event (September 2019) in Murcia (Caballero et al., 2019) and after the storm Gloria (January 2020) in the Ebro delta. We show that Sentinel-2 satellites are the new eyes on the coastal regions, which will enable for new endeavours in monitoring, change detection, and mapping of coastal zones.
\end{abstract}

Key words: Copernicus programme, Water quality, Flooding, Bathymetry, Harmful algal blooms.

Acknowledgments: This research was funded by the Spanish Ministry of Science, Innovation and Universities (MCIU), the State Research Agency (AEI), and the European Regional Development Fund (ERDF) in the frame of the Sen2Coast Project (RTI2018098784-J-I00). 


\section{References:}

Caballero, I., Steinmetz, F. and Navarro, G. (2018a). Evaluation of the first year of operational Sentinel-2A data for retrieval of suspended solids in medium-to high-turbidity waters. Remote Sensing, 10(7), 982.

Caballero, I., Navarro, G., and Ruiz, J. (2018b). Multi-platform assessment of turbidity plumes during dredging operations in a major estuarine system. International journal of applied earth observation and geoinformation, 68, 31-41.

Caballero, I., Ruiz, J. and Navarro, G. (2019). Sentinel-2 Satellites Provide Near-Real Time Evaluation of Catastrophic Floods in the West Mediterranean. Water, 11(12), 2499.

Caballero, I., \& Stumpf, R. P. (2019). Retrieval of nearshore bathymetry from Sentinel-2A and 2B satellites in South Florida coastal waters. Estuarine, Coastal and Shelf Science, 226, 106277.

Caballero, I., Stumpf, R. P., and Meredith, A. (2019). Preliminary assessment of turbidity and chlorophyll impact on bathymetry derived from Sentinel-2A and Sentinel-3A satellites in South Florida. Remote Sensing, 11(6), 645.

Caballero, I., \& Stumpf, R. P. (2020). Towards Routine Mapping of Shallow Bathymetry in Environments with Variable Turbidity: Contribution of Sentinel-2A/B Satellites Mission. Remote Sensing, 12(3), 451.

Caballero, I., et al. (2020). New capabilities of Sentinel-2A/B satellites to monitor small harmful algal blooms in complex coastal waters. Scientific Reports (under revision). 


\title{
A MINIMUM VIABLE ECOSYSTEM OF SERVICES FOR CITIZEN OBSERVATORIES: COS4CLOUD TACKLING TECHNOLOGICAL CHALLENGES IN THE AGE OF OPEN SCIENCE
}

\author{
J. Piera* ${ }^{1}$, K. Soacha ${ }^{1}$, and Cos4Cloud Consortium \\ ${ }^{1}$ Marine Biology and Oceanography Department,Institute of Marine Sciences, Barcelona, SPAIN. \\ jpiera@icm.csic.es, soacha@icm.csic.es
}

\begin{abstract}
Citizen science is one of the eight priorities of the European Open Science Agenda, together with the creation of the European Open Science Cloud (EOSC, 2018). EOSC incorporates the European Commission's vision of an extensive infrastructure to support and develop open science in Europe and beyond (European Commission, 2018a).
\end{abstract}

Within this framework, the Horizon 2020 program (2019-2022) Co-designed Citizen Observatories Services for the European Open Science Cloud, 'Cos4Cloud', aspires to integrate citizen science in the EOSC ecosystem. Cos4Cloud will develop essential research and technology to co-design and prototype innovative services to address critical challenges faced by citizen observatories. The final goal is to improve the implementation of existing and future citizen observatories and to contribute to ensuring their sustainability European Commission (2018b).

Currently, there are dozens of citizen observatories in Europe (WeObserve, 2018). The growing evolution of these COs yields in a community of citizen science that is continuously expanding not only in Europe but also on a global scale. This, in turn, represents large-scale challenges for citizen observatories that must facilitate an efficient capture, identification and validation of data, and the stewardship and storage of large volumes of data in different formats. Additionally, COs must ensure interoperability at a local, regional, and global level that allows scaling the impact of the data overcoming the geographic, thematic, or even linguistic barriers for doing research.

The aim of this talk is to present the Minimum Viable Ecosystem (MEV) proposed by Cos4Cloud for tackling the challenges faced by citizen observatories. The MEV will be based on innovative services using deep machine learning, automatic video recognition, advanced mobile app interfaces, and other cutting-edge technologies. The MVE will follow open standards to ensure their interoperability, and offered in agile, fit-for-purpose and sustainable site available through EOSC hub, including a discovery service, to both traditional and citizen scientists. 
Key words: Citizen science, Open Science, Citizen Observatories, Participatory monitoring, Technological services

Acknowledgments: Cos4Cloud (Co-designed Citizen Observatories Services for the European Open Science Cloud) is a project supported by European Union's Horizon 2020 Research and Innovation Programme under grant agreement No. 863463.

\section{References:}

European Commission (2018a). Open Science Policy Platform Recommendations. Brussels. https://doi.org/10.2777/958647.

European Commission (2018b). Implementation Roadmap for the European Open Science Cloud. Brussels.

EOSC (2018). Prompting an EOSC in practice: Final report and recommendations of the Commission 2nd High Level Expert Group [2017-2018] on the European Open Science Cloud (EOSC). Brussels. https://doi.org/10.2777/112658.

WeObserve (2018). An Ecosystem of Citizen Observatories for Environmental Monitoring. D2.1 EU Citizen Observatories Landscape Report - Frameworks for mapping existing CO initiatives and their relevant communities and interactions. 


\title{
HIGH-RESOLUTION BATHYMETRIC MONITORING USING 3D POINT CLOUD DATA ANALYSIS
}

\author{
J. Urpi*1, D. Amblas ${ }^{1}$ and A. Abellán ${ }^{2}$ \\ ${ }^{1}$ Dept. of Earth and Ocean Dynamics, University of Barcelona, Barcelona, SPAIN. \\ juliaurpi@gmail.com,damblas@ub.edu \\ ${ }^{2}$ Engineering Geology \& Geohazards, University of Leeds, Leeds, UNITED KINGDOM. \\ a.abellan@leeds.as.uk
}

\begin{abstract}
Key aspects on coastal management include a better understanding of bathymetric changes on the seafloor, such as the stability and dispersal of dredged and disposed material together with seabed disturbance due to fishing activities. Some fundamental research questions that need to be addressed include: Which processes control seabed dynamics? What are the typical scales for the rearrangement of bed material? To what extent are morphological changes predictable? What is the long-term stability of human-made submarine slopes? Answering to these and many other questions might be limited by our current ability to "see" these changes in our observational evidences, including a lack of systematic data acquisition of high-resolution nature.
\end{abstract}

Modern multibeam echosounders have the potential to monitor seafloor changes through the analysis of 3D point clouds, similarly to what is being done in other disciplines using LiDAR (Lague et al., 2013). However, the original 3D information, contained in the point clouds, is normally gridded in marine sciences during data pre-treatment, which may come along with a certain information loss.

For this project, we have imported a series of concepts and methods that are being routinely applied when investigating 3D landscape evolution to analyse changes in seafloor with unprecedented level of detail. For this purpose, a series of bathymetric datasets of a dragged zone in the Catalan coastal area (Spain), have been studied by using an algorithm to compute signed distances directly between two point clouds (M3C2). Results show change detection and seabed dynamics on this specific area during the last decade, shedding light into long-term disturbance of seabed due to sand dredging operations.

Key words: Seabed high-resolution monitoring, Multibeam bathymetry, Point cloud data analysis

\section{References:}

Lague, D., Brodu, N. and Leroux, J. (2013). Accurate 3D comparison of complex topography with terrestrial laser scanner: Application to the Rangitikei canyon (NZ). ISPRS Journal of Photogrammetry and Remote Sensing, 82, 10-26. 


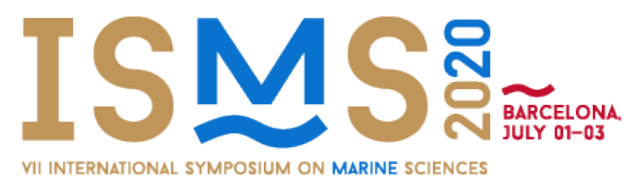

VII International Symposium on Marine Sciences

ISMS 2020

Barcelona (Spain), $1^{\text {st }}-3^{\text {rd }}$ July 2020

\section{MACCAM: A PROXY TO CARRYING CAPACITY FOR MEDITERRANEAN AQUACULTURE}

\author{
K. Toledo-Guedes*1, G. Martínez ${ }^{2}$, V. Fernandez-Gonzalez ${ }^{3}$, F. Romero ${ }^{4}$, E. \\ Carbonell Garzón ${ }^{5}$, M.M. Agraso ${ }^{6}$ and P. Sanchez-Jerez ${ }^{7}$ \\ 1,3,4, 5,7 Department of Marine Science and Applied Biology, University of Alicante, Alicante, \\ SPAIN. \\ ktoledo@ua.es,victoria.fernandez@ua.es,frp13alu.ua@gmail.com,psanchez@ua.es \\ ${ }^{2,6}$ Centro Tecnológico Acuicultura Andalucía (CTAQUA). Muelle Comercial S/N \\ 11500, El Puerto de Santa María, Cádiz, SPAIN \\ g.martinez@ctaqua.es,mm.agraso@ctaqua.es
}

\begin{abstract}
Carrying capacity models (CCMs) allow defining and limiting aquaculture production in open sea cages. CCMs use in marine spatial planning is growing, since there is a need to cover environmental and social needs, given aquaculture is an activity that is carried out in a public space. Thus, aquaculture management and planning may directly affect the environment (in a wide sense) where it is placed. In a previous project (MIMECCA) a theoretical model aimed as a proxy of aquaculture carrying capacity was delivered. The present project (MACCAM) was developed to advance in an applicable tool, which involves a validation and readjustment of the model. For that, we carried out a validation process based on the Environmental Monitoring Plan proposed by JACUMAR. We tested indicators of environmental quality state (granulometry $<63 \mu \mathrm{m}$, Total Free Sulfides and polychaete assemblages) for three different farms: a low production farm (400 tonnes/year), medium production farm (1500 tonnes/year) and large production farm (4000 tonnes/year). Results showed that, those farms surpassing the theoretical carrying capacity proxy as calculated by the model, had also surpassed some environmental thresholds. This indicates that the model seems to be calibrated to real conditions, although it is necessary to apply this methodology to more farms in order to account for more spatial variability. Models that deliver a proxy to carrying capacity and are easily applied may be useful tools for both decision makers and the industry. They could facilitate future marine spatial planning and advice regarding new industry investments willing to expand the production.
\end{abstract}

Key words: Carrying capacity, validation, environmental interactions

Acknowledgments: This project is carried out with the collaboration of Fundación Biodiversidad, of the Ministerio para la Transición Ecológica y el Reto Demográfico, through Pleamar Program, cofinanced by FEMP. We thank the collaboration of the three companies that gave us access to their facilities. 


\title{
REAL-TIME MARINE FISH DETECTION USING DEEP LEARNING FOR BEHAVIOURAL STUDIES UNDER LABORATORY CONDITIONS
}

\author{
Marco Signaroli ${ }^{1}$, Josep Alós ${ }^{2}$ and Arancha Lana ${ }^{3}$ \\ 1, 2,3 Instituto Mediterráneo de Estudios Avanzados, IMEDEA (CSIC-UIB), C/ Miquel Marquès, \\ 21, 07190 Esporles, Illes Balears, SPAIN. \\ marco.signaroli@gmail.com,alos@imedea.uib-csic.es, alana@imedea.uib-csic.es
}

\begin{abstract}
In last years, deep learning has revolutionized almost every scientific discipline and everyday tasks. In behavioural ecology, deep learning allows us to automatize the acquisition of animal behaviour and to improve the analysis of large amounts of behavioural data in realistic behavioural arenas. Here, we have trained and validated an image-based deep learning algorithm, the Faster R-CNN (Faster Region-based Convolutional Neural Network), for real-time detection of marine fish under laboratory conditions, aiming to obtain an automatic tool to study fish behaviour from video recordings in complex, but more realistic, marine behavioural arenas. For the training, we have used a total of 14000 labelled images and a data augmentation technique to explore the performance of the algorithm. Then, we have validated its functioning at different training degrees, processing more than 52039 frames for every validation, with and without the presence of a marine fish in normal and altered (introducing a novel object) laboratory conditions. The neural network in its final and best version, trained with all the images and with data augmentation, reached an accuracy of $93 \%$, proving to be a good instrument to study fish behavioural ecology in a non-invasive way. Therefore, we offer a new machine learning-based tool to study fish behaviour in complex marine behavioural arenas that would help understanding fundamental and allied questions of behavioural diversity.
\end{abstract}

Key words: deep learning, behavioural ecology, fish detection.

Acknowledgments: I would like to acknowledge all the members of the Fish Ecology Group of the Mediterranean Institute for Advanced Studies (IMEDEA) and of the Laboratory of Marine and Aquaculture Research (LIMIA, Spain).

\section{References:}

Brown A, Bivort B. Ethology as a physical science. bioRxiv. 2017:1-7.

Goodfellow I, Bengio Y, Courville A. Deep Learning. 2016:785.

Christin S, Hervet É, Lecomte N. Applications for deep learning in ecology. Methods Ecol Evol. 2019;10(10):1632-1644.

Ren S, He K, Girshick R, Sun J. Faster R-CNN: Towards Real-Time Object Detection with Region Proposal Networks. IEEE Trans Pattern Anal Mach Intell. 2017;39(6):1137-1149. 


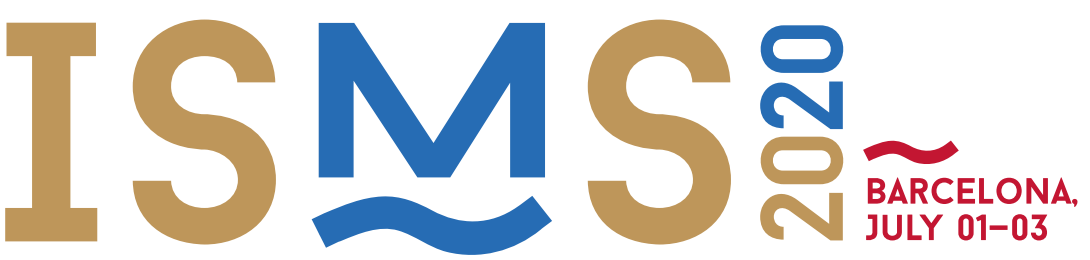

VII INTERNATIONAL SYMPOSIUM ON MARINE SCIENCES BARCY 01-03

\section{ORAL COMMUNICATIONS}

\section{THE PHYSICAL BASES OF MARINE SCIENCES}




\title{
THERMOHALINE INTRUSIONS AND DIAPYCNAL MIXING IN THE CAPE VERDE FRONTAL ZONE
}

\author{
A. Rodríguez-Santana ${ }^{*}{ }^{1}$, N. Burgoa ${ }^{1}$, A. Martínez-Marrero ${ }^{2}$, L. Valencia $^{3}$, A. \\ Marrero-Díaz ${ }^{1}$ and F. Machín ${ }^{1}$ \\ ${ }^{1}$ Departamento de Física, Universidad de Las Palmas de Gran Canaria, Las Palmas de Gran \\ Canaria, ESPAÑA. \\ angel.santana@ulpgc.es,nadia.burgoa@ulpgc.es,angeles.marrero@ulpgc.es, \\ francisco.machin@ulpgc.es \\ ${ }^{2}$ Instituto de Oceanografía y Cambio Global, Universidad de Las Palmas de Gran Canaria, Las \\ Palmas de Gran Canaria, ESPAÑA. \\ antonio.martinez@ulpgc.es \\ ${ }^{3}$ Escuela de Ciencias del Mar, Pontificia Universidad Católica de Valparaíso, Valparaíso, CHILE. \\ lpvalenciac@gmail.com
}

The Cape Verde Frontal Zone (CVFZ) is described as a strong meandering thermohaline front from near Cape Blanc to Cape Verde islands. It shows sharp gradients in temperature and salinity in the upper waters and the presence of intrusions of North Atlantic Central Waters (NACW) and South Atlantic Central Waters (SACW) across the front. These thermohaline intrusions have vertical and horizontal scales on 10-100 $\mathrm{m}$ and $1-100 \mathrm{~km}$, respectively.

During November 2017 was carried out a multidisciplinary survey FLUXES II (FLUXES project) in the CVFZ and temperature-salinity and microstructure data were collected with high spatial resolution along several sections. This survey provides an excellent opportunity to study these intrusions and double-diffusion diapycnal mixing in this thermohaline front.

Interleaving motions are thought to be driven by buoyancy forces arising from differential mixing of heat and salt by double diffusion. The slope of intrusions relative to isopycnal surfaces was studied, finding cases where salt-finger density fluxes exceed those of diffusive convection and viceversa. Also, we analyze the effect of vertical shear on the double diffusion processes.

Key words: Cape Verde Frontal Zone, Thermohaline Front, Interleaving Process, Diapycnal Mixing, Double Diffusion.

Acknowledgments: This work has been supported by the Spanish government (Ministerio de Economía y Competitividad) through project FLUXES (CTM2015-69392- C3-3- R). 


\section{References:}

Arcos-Pulido, M., A., Rodríguez-Santana, Emelianov, M., Paka, V., Arístegui, J., Benavides, M., Sangrà, P. , Machín, F., García-Weil, L., Estrada-Allis, S. (2014). Diapycnal nutrient fluxes on the northern boundary of Cape Ghir upwelling region. Deep-Sea Research I, 84, 100-109.

Martínez-Marrero, A., Rodríguez-Santana, A., Hernández-Guerra, A., Fraile-Nuez, E., López-Laatzen, F., Vélez-Belchí, P., Parrilla, G. (2008). Distribution of water masses and diapycnal mixing in the Cape Verde Frontal Zone. Geophysical Research Letters, 35, L07609.

Schmitt, R.W., Ledwell, J.R., Montgomery, E.T., Polzin, K.L., Toole, J.M. (2005). Enhanced Diapycnal Mixing by Salt Fingers in the Thermocline of the Tropical. Science, 308, 685-688. 


\title{
EDDY CORRIDORS OF THE NORTHEASTERN TROPICAL AND SUBTROPICAL ATLANTIC OCEAN
}

\author{
B. Aguiar-González *1, F. Machín ${ }^{1}$, Á. Rodríguez-Santana ${ }^{1}$ and Á. Marrero-Díaz ${ }^{1}$ \\ ${ }^{1}$ OFYGA, Departamento de Física, Universidad de Las Palmas de Gran Canaria, Las Palmas de \\ Gran Canaria, SPAIN. \\ borja.aguiar@ulpgc.es,francisco.machin@ulpgc.es,angel.santana@ulpgc.es, \\ angeles.marrero@ulpgc.es
}

\begin{abstract}
The northeastern tropical and subtropical Atlantic Ocean are highly populated in longlived mesoscale eddies which propagate westward following nearly zonal pathways. Based on remotely sensed altimetry data (1992-2006) and in situ observations (1998, 2002), Sangrà et al. (2009) described the Canary Eddy Corridor for the first time as a zonal long-lived mesoscale eddy corridor between $22.1^{\circ} \mathrm{N}-29.1^{\circ} \mathrm{N}$, mainly driven by the downstream perturbation of the Canary Current and the Trade Winds against the Canary Islands.

In this work we provide an updated demography of long-lived westward-propagating eddies in the northeastern tropical and subtropical Atlantic Ocean $\left(12^{\circ} \mathrm{N}-40^{\circ} \mathrm{N}\right)$. We do this based on a daily global mesoscale ocean eddy dataset for an extended period of altimetry observations (1992-2018). Results show recurrent latitudinal patterns on the Lagrangian evolution of geometric eddy properties which provide a deeper insight on their intrinsic dynamics as coherent entities transporting water mass and biogeochemical properties as far as to the mid-Atlantic Ocean.
\end{abstract}

Key words: Northeastern Tropical and Subtropical Atlantic Ocean, Long-lived eddy corridors, Eddy demography

Acknowledgments: The first author is grateful for the award of a PostDoctoral grant (PICULPGC-2017-CIENCIAS-3) from the Universidad de Las Palmas de Gran Canaria. This work has been supported by the Spanish government (Ministerio de Economia y Competitividad) through project FLUXES (CTM2015-69392- C3-3- R).

\section{References:}

Sangrà, P., Pascual, A., Rodríguez-Santana, A., Machín, F., Mason, E., McWiliams, J.C., Pelegrí, J.L., Dong, C., Rubio, A., Arístegui, J., Marrero-Díaz, A., Hernández-Guerra, A., Martínez-Marrero, A. and Auladell, M. (2009). The Canary Eddy Corridor: A major pathway for long-lived eddies in the subtropical North Atlantic. Deep Sea Research I 56, 2100-2114. 


\title{
EVALUATION OF THE ERA* OCEAN FORCING PRODUCT UNDER STORM SURGE CONDITIONS IN THE ADRIATIC SEA Evgeniia Makarova $^{1}$, Ana Trindade ${ }^{2,3}$, Marcos Portabella ${ }^{2}$
}

\author{
${ }^{1}$ Faculty of Earth Sciences, University of Barcelona, Barcelona, SPAIN. \\ quaxoc@gmail.com \\ ${ }^{2}$ Institut de Cièncias del Mar (ICM), CSIC, Barcelona, SPAIN. \\ atrindade@icm.csic.es,portabella@icm.csic.es \\ ${ }^{3}$ Universidad Politécnica de Cataluña (ICM), CSIC, Barcelona, SPAIN.
}

\begin{abstract}
:
Storm surges in the Adriatic Sea are periodic extreme weather events that cause high economical losses and endanger human lives. These events are caused by an atmospheric pressure depression and persistent south-easterly winds (Sirocco). This work focuses on further developing and verifying an enhanced ocean forcing product (ERA*) in the Mediterranean Sea, with the aim to improve the storm surge prediction capabilities in the Adriatic Sea region [1], [2].

The ERA* is a corrected ERA-Interim reanalysis product (ERAi) provided by the European Centre for Medium-range Weather Forecasts (ECMWF) [3]. A scatterometerbased correction, using high spatial resolution ocean stress-equivalent winds (U10S) from complementary scatterometers (ASCAT-A/B, and OSCAT), is proposed to reduce ERAi local U10S biases. Since local biases are relatively persistent over time but their persistence is regionally dependent, ERA* has several configurations of the temporal windows applied to calculate the scatterometer-based corrections. The accuracy of the product is being evaluated against a $25-\mathrm{km}$ resolution U10S product from an independent scatterometer (HSCAT).

On the global scale, Trindade et al. [3] show that ERA*, in 2 or 3-day temporal window configuration, outperforms the ERAi product, showing about a $10 \%$ error variance reduction when compared to HSCAT. In the present work, the tests for the Mediterranean region, which generally has higher wind variability (and therefore reduced persistence), show that the ERA* 3-day configuration product still outperforms ERAi, but presents higher errors than in open ocean tropical and extra-tropical regions. For the Adriatic Sea, both ERAi and ERA* products show similar quality, although ERA* shows smaller zonal and meridional U10S biases than ERAi. Similar results are obtained when evaluating the product under storm surge conditions in the Adriatic.

Due to rapidly changing winds in the Mediterranean, and more in particular in the Adriatic region, where coastal effects are more prominent, we also plan to verify the quality of the ERA* 1-day configuration, notably during storm surge events.
\end{abstract}


Key words: Ocean forcing, storm surge, scatterometer winds, numerical weather prediction output.

\section{References}

[1] Marco Bajo, Francesco De Biasio, Georg Umgiesser, Stefano Vignudelli, Stefano Zecchetto, "Impact of using scatterometer and altimeter data on storm surge forecasting", Ocean Modelling, Volume 113, 2017, Pages 85-94, ISSN 1463-5003.

[2] Francesco De Biasio, Marco Bajo, Stefano Vignudelli, Georg Umgiesser \& Stefano Zecchetto (2017) "Improvements of storm surge forecasting in the Gulf of Venice exploiting the potential of satellite data: the ESA DUE eSurge-Venice project”, European Journal of Remote Sensing, 50:1, 428-441.

[3] Trindade, A., Portabella, M., Stoffelen, A., Lin, W., and Verhoef, A., "ERAstar: a high-resolution ocean forcing product", IEEE Trans. Geosci. Rem. Sens., 58 (2), 1337-1347, 2020. 


\title{
ON THE SPATIOTEMPORAL DIVERSITY OF ATLANTIC NIÑO AND ASSOCIATED RAINFALL VARIABILITY OVER WEST AFRICA AND SOUTH AMERICA
}

\author{
Ignasi Vallès-Casanova**1,2, Sang-Ki Lee ${ }^{2}$, Gregory R. Foltz ${ }^{2}$ and J.L. Pelegrí ${ }^{1}$ \\ ${ }^{1}$ Department of Phisical Oceanography, Institute of Marine Science, Barcelona, SPAIN. \\ ${ }^{2}$ NOAA Atlantic Oceanographic and Meteorological Laboratory, Miami, Florida, USA \\ valles@icm.csic.es
}

\begin{abstract}
Warm phases of the Atlantic Zonal Mode (AZM), known as Atlantic Niño (AN), are caused by a variety of mechanisms. In this study we analyze the diversity of AN-events through an inter-event empirical orthogonal function (EOF) methodology. The first two orthogonal modes, which explain $30 \%$ and $24 \%$ of the inter-annual variability, allow describing four of the principal spatio-temporal patterns in sea surface temperature (SST). The first two contrast the timing of dissipation (i.e., early-terminating versus persistent), while the other two the timing of onset (i.e., early-onset versus late-onset). Largely consistent with the differences in the timings of onset and dissipation, these four varieties display remarkable differences in rainfall response over West Africa and South America. Some are also subject to onset mechanisms that involve preconditioning in boreal spring from the Atlantic Meridional Mode or El Niño in the Pacific, while for others there is no clear source of external forcing.
\end{abstract}

Key words: Tropical Atlantic Variability, Atlantic Niño, West African Monsoon.

Acknowledgments: This work was supported by the Spanish Government funding through projects VA-DE-RETRO (CTM2014-56987-P) and SAGA (RTU2018-100844-BC33), and by NOAA's Climate Program Office, Climate Variability and Predictability Program (award GC16-207) and NOAA/AOML. I.V.C. was funded through FPI contract (BES-2015-071314).

\section{References:}

Foltz, G. R., and McPhaden, M. J. (2010). Interaction between the Atlantic meridional and Niño modes. Geophys. Res. Lett., 37(18), L18604, https://doi.org/10.1029/2010g1044001.

Lee, S.-K., Dinezio, P. N., Chung, E.-S., Yeh, S.-W., Wittenberg, A. T., and Wang, C. (2014). Spring 
persistence, transition, and resurgence of El Niño. Geophys. Res. Lett., 41(23), 8578-8585. https://doi.org/10.1002/2014g1062484.

Lübbecke, J. F., Rodríguez-Fonseca, B., Richter, I., Martín-Rey, M., Losada, T., Polo, I., and Keenlyside, N. S. (2018). Equatorial Atlantic variability-modes, mechanisms, and global teleconnections. WIRES Climate Change, 9(4). https://doi.org/10.1002/wcc.527.

Richter, I., Behera, S. K., Masumoto, Y., Taguchi, B. Sasaki, H. and Yamagata T. (2012). Multiple causes of interannual sea surface temperature variability in the equatorial Atlantic Ocean. Nat. Geosci., 6(1), 4347. https://doi.org/10.1038/ngeo1660. 


\title{
EXPLORING HYDROGRAPHICAL STRUCTURES IN THE CAPE VERDE FRONTAL ZONE THROUGH IN SITU DATA AND NUMERICAL MODELLING DURING FLUXES-II SURVEY
}

\author{
I. Hernández-García*1, F. Machín ${ }^{1}$ and J. Coca ${ }^{2}$ \\ ${ }^{1}$ Physics Department, OFyGA, ULPGC. \\ ines.hernandez104@alu.ulpgc.es, francisco.machin@ulpgc.es \\ ${ }^{2}$ División de Robótica y Oceanografía Computacional (IUSIANI), ULPGC. \\ jcoca@pesca.gi.ulpgc.es
}

\begin{abstract}
The Cape Verde Frontal Zone (CVFZ) is a dynamically complex region located at the eastern North Atlantic Subtropical Gyre $\left(20^{\circ} \mathrm{W}\right.$ to $\left.30^{\circ} \mathrm{W}, \sim 20^{\circ} \mathrm{N}\right)$, where the warmer and more saline North Atlantic Central Water (NACW) and the colder and less saline South Atlantic Central Water (SACW) interact. It is defined by the intersection of the 36.0 isohaline with the $150 \mathrm{~m}$ depth isobath. The CVFZ presents high variability due to the presence of lateral intrusions, filaments from the upwelling system, and mesoscale and submesoscale eddy fields with sharp thermohaline gradients. Temperature and salinity decrease with depth, which compensates their effect on density and makes the front dynamically stable in the vertical direction. This project aims to analyse the features at the CVFZ during November 2017 FLUXES-II cruise using the in situ data from ship CTD stations, a SeaSoar, and two underwater gliders with biochemical and dynamical instruments. The variables used on this study were potential temperature, practical salinity, potential density, and oxygen concentration. Outputs from the Copernicus Mercator model were compared with in situ data to determine the model skill on reproducing the mesoscale and submesoscale features. Wavelet analyses were conducted to compare the spatial scales of variability that can be resolved with the sampling methods. Results showed that the ship CTD data reaches the greatest depth of all the sampling methods, and the SeaSoar is the fastest method. The gli der and the SeaSoar capture the smallest scales and show the frontal features with greater detail, while the glider has a slightly better resolution. The surface layer showed the highest variability. The main features found were intrusions of SACW into the NACW. It was found a tilted lateral intrusion, located at slightly greater depths than the other intrusions, that might be due to the deformation of a previously existing intrusion.
\end{abstract}

Key words: Frontal zone, Lateral intrusions, Upwelling, Mesoscale, Data sources

Acknowledgments: This work has been supported by the FLUXES project (CTM201569392-C3-3-R) funded by the Spanish National Research Program and the European Regional Development Fund (MINECO-FEDER). 


\title{
TESTING THE ROLE OF MEDITERRANEAN THERMOHALINE CIRCULATION AS A SENSOR OF TRANSIENT CLIMATE EVENTS (TIMED-PROJECT)
}

\author{
I. Cacho* ${ }^{1}$, L. Pena ${ }^{1}$, F. Lirer ${ }^{2}$ and TIMED team \\ ${ }^{1}$ GRC Geociències Marines, Departament de Dinàmica de la Terra i de l'Oceà, Facultat de \\ Ciències de la Terra, Universitat de Barcelona, SPAIN. \\ icacho@ub.edu,lpena@ub.edu \\ ${ }^{2}$ Istituto di Scienze Marine-CNR, Sede Napoli, 80133 Napoli, ITALY. \\ fabrizio.lirer@cnr.it
}

\begin{abstract}
The Mediterranean Sea is an excellent sensor of transient climate conditions at different time scales. Changes in Medierranean water properties result from complex interactions between the Atlantic inflow, local climate and north and south atmospheric teleconnections. Climate models anticipate changes in these circulation systems within decades. Thus it becomes critical to understand the natural range of variations in the Mediterranean Thermohaline Circulation (MedTHC). This situation set the basis for the development of the ERC project TIMED. Here we summarize the main results obtained in the framework of this project currently in full development. TIMED is exploring changes in deep and intermediate circulation patterns of the Western Mediterranean Sea associated to a deglacial weakening event in deep overturning that led to the last Organic Rich Layer (ORL) formation in the Alboran Sea (Pérez-Asensio et al., 2020). TIMED is also addressing the role of potential changes of properties in the Atlantic inflow on the MedTHC evolution (Català et al., 2019). But one of the most intriguing questions regarding the whole MedTHC system is the interconnection behaviour between its two basins during the time of this ORL and the last sapropel formation. TIMED is addressing this question through the novel application of $\mathrm{Nd}$ isotopes. In this regard, one of the great achievements of TIMED has been the installation of the LIRA-Panthalassa infrastructure in the University of Barcelona that led us to validate the application of this technique to characterize current oceanography in the central sector of the Mediterranean Basin (Garcia-Solsona et al., 2020). TIMED is also focussing in the climate variability of the last two millennia, trying to set up the baseline of MedTHC variability in relation to different modes of currently active multidecadal climate variability (Cisneros et al., 2019; Margaritelli et al., 2020).
\end{abstract}

Key words: Mediterranean Thermohaline Circulation, Nd isotopes, Organic Rich Layer, Sapropel

Acknowledgments: This study has received funding from the European Research Council (ERC) through the ERC-Consolidator project TIMED (Grant Agreement No. 683237). TIMED team: I. Bladè, S. Campderros, A. Caruso, A. Català, H. Checa, M. Cisneros- 
Bermejo, M. de la Fuente, J. Frigola, E. Garcia-Solsona, G. Margariteli, A. Marchan, E. Paredes, J.N. Pérez-Asensio, A. Sanchez-Vidal, J. Torner and S. Trias.

\section{References:}

Català, A., Cacho, I., Frigola, J., Pena, L.D. and Lirer, F. (2019). Holocene hydrography evolution in the Alboran Sea: a multi-record and multi-proxy comparison. Climate of the Past, 15 (3), 927-942.

Cisneros, M., Cacho, I., Frigola, J., Sanchez-Vidal, A., Calafat, A. et al. (2019). Deep-water formation variability in the north-western Mediterranean Sea during the last $2500 \mathrm{yr}$ : A proxy validation with present-day data. Global and Planetary Change, 177, 56-68.

Garcia-Solsona, E, Pena, L.D., Paredes, E., Pérez-Asensio, J.N., Quirós Collazos, L. et al. (2020). Rare Earth Elements and $\mathrm{Nd}$ isotopes as tracers of modern ocean circulation in the central Mediterranean Sea. Progress in Oceanography (in rev.).

Margaritelli, G., Cacho, I., Català, A., Bellucci, L.G., Lubritto, C. et al. (2020). Persistent warm Mediterranean surface waters during the Roman period. Scientific Reports (in rev.).

Pérez-Asensio, J.N., Frigola, J., Pena, L.D., Sierro, F.J., Reguera, M.I. et al. (2020). Changes in western Mediterranean thermohaline circulation in association with a deglacial Organic Rich Layer formation in the Alboran Sea. Quaternary Science Reviews, 228, 106075. 


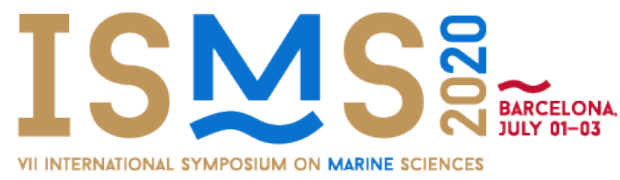

VII International Symposium on Marine Sciences

ISMS 2020

Barcelona (Spain), $1^{\text {st }}-3^{\text {rd }}$ July 2020

\section{WHERE DO THE NEAR-BOUNDARY SUBPOLAR NORTH ATLANTIC SINKING WATERS GO? A LAGRANGIAN-BASED STUDY WITH A HIGH-RESOLUTION GLOBAL OCEAN MODEL}

\author{
J.M. Sayol ${ }^{1}$, S. Georgiou' ${ }^{1}$, S.L. Ypma ${ }^{1}$, N. Brüggemann², \\ H.A. Dijkstra ${ }^{3}$ and C.A. Katsman ${ }^{1}$ \\ ${ }^{1}$ Environmental Fluid Mechanics, Faculty of Civil Engineering and Geosciences, \\ Delft University of Technology, Delft, THE NETHERLANDS \\ J.M.SayolEspana@tudelft.nl,S.Georgiou@tudelft.nl,S.L.Ypma@tudelft.nl, \\ C.A.Katsman@tudelft.nl
}

${ }^{2}$ Faculty of Mathematics, Informatics and Natural Sciences, University of Hamburg, Hamburg, GERMANY

nils.brueggemann@uni-hamburg.de

${ }^{3}$ Institute for Marine and Amosferic Research Utrecht, Utrecht University, Utrecht, THE NETHERLANDS

H.A.Dijkstra@uu.nl

\begin{abstract}
Previous studies based on global realistic models have shown that most of the sinking associated with the Atlantic Meridional Overturning Circulation (AMOC) occurs below the mixed layer depth nearby the subpolar North Atlantic boundaries (Katsman et al., 2018; Sayol et al., 2019). However, it is unclear what the contribution of these nearboundary sinking waters is to the formation of the dense Labrador Sea Water and to the lower limb of the AMOC. Recently, an idealized model that mimics the essential properties of the Labrador Sea has revealed that a significant part of the near-boundary water-masses enter the interior of the Labrador Sea, where they spend from months to a few years, to later reenter into the boundary current at a higher density (Georgiou et al., 2020).
\end{abstract}

Mesoscale eddies are thought to aid the near-boundary water-masses to cross from the boundary current to the interior of the Labrador Sea and viceversa (Brüggemann and Katsman, 2019; Georgiou et al., 2019). To shed light on the preferred pathways of the sinking near-boundary waters and on the water-mass transformation that they experience, we have applied two Lagrangian approaches using a high resolution global ocean simulation. First, we have tracked forward the water-masses with the strongest rate of sinking near the boundaries. Second, we have tracked backward the water-masses that exit the Labrador Sea following the Labrador Sea Current. These simulations have been performed with the Parallel Ocean Program model, in which we have advected thousands of passive particles with model daily data, and a nominal spatial resolution of 0.1 degree and 42 z-levels for several years. Based on this Lagrangian view of the 
circulation, we assess the preferred routes of the waters involved in near-boundary sinking and of the Labrador Sea Current, their properties, how these characteristics change over time and possible connections between them.

Key words: Sinking, North Atlantic, Labrador Sea Water, Watermass transformation, Lagrangian pathways

Acknowledgments: J.M. Sayol, S. Georgiou, S.L. Ypma, N. Brüggemann and C.A. Katsman acknowledge the VIDI grant awarded to C.A. Katsman by the Netherlands Organization for Scientific Research (NWO) with number 864.13.011.

\section{References:}

Brüggemann, N. and Katsman, C.A. (2019). Dynamics of downwelling in an eddying marginal sea: contrasting the Eulerian and the isopycnal perspective. Journal of Physical Oceanography 49 (11), 3017-3035.

Georgiou, S., Van der Boog, CG., Brüggemann, N., Ypma, S.L., Pietrzak, J.D. and Katsman, C.A. (2019). On the interplaybetween downwelling, deep convection and mesoscale eddiesin the Labrador Sea. Ocean Modelling 135, 56-70.

Georgiou, S., Ypma, S.L., Brüggemann, N., Sayol, J.M., Pietrzak, J.D. and Katsman, C.A. (2020).

Pathways of the water masses exiting the Labrador Sea: the importance of boundary-interior exchanges. Ocean Modelling (in press)

Katsman, C.A., Drijfhout, S.S., Dijkstra, H.A., Spall, M.A. (2018). Sinking of Dense North Atlantic Waters in a Global Ocean Model: Location and Controls. Journal of Geophysical Research: Oceans 123 (5), 3563-3576.

Sayol, J.M., Katsman, C., and Dijkstra, H. (2019). Seasonal and regional variations of sinking in the subpolar North Atlantic from a high-resolution ocean model. Ocean Science 15, 1033-1053. 


\title{
DYNAMIC OF THE NORTH-WESTERN ALBORAN SEA UPWELLING FROM LOCAL AND REMOTE OBSERVATIONS
}

\author{
M. Bolado-Penagos**1, S. Sirviente ${ }^{1}$, I. Sala ${ }^{2}$, A. Vázquez ${ }^{3}$ and M. Bruno ${ }^{1}$ \\ ${ }^{1}$ Department of Applied Physics, Faculty of Marine and Environmental Sciences, University of \\ Cádiz, Puerto Real, 11510 Cádiz, SPAIN. \\ marina.bolado@uca.es, sara.sirviente@uca.es,miguel.bruno@uca.es \\ ${ }^{2}$ Department of Biology, Faculty of Marine and Environmental Sciences, University of Cádiz, \\ Puerto Real, 11510 Cádiz, SPAIN. \\ iria.sala@uca.es \\ ${ }^{3}$ Department of Applied Physics, School of Engineering, University of Cádiz, Puerto Real, 11510 \\ Cádiz, SPAIN. \\ agueda.vazquez@uca.es
}

\begin{abstract}
The north-western (NW) Alborán Sea is characterized by the presence of a quasi-permanent coastal upwelling, which is enhanced or weakened by the effects of local winds and the southward drifting of the Atlantic Jet (AJ) (e.g. Sarhan et al., 2000; Macías et al., 2008). With the aim to evaluate the interface oscillations and the spatial-temporal variability of the coastal upwelling, a thermistors chain was moored during one-month and several Lagrangian drifters were deployed. Additionally, Conductivity, Temperature and Depth (CTD) profiles were carried out along the NW-Alborán Sea. Time series of local winds and Mean Sea Level Pressure (MSLP) over the Ligurian Sea were also assessed. The high temporal resolution of the temperature measurements (1-minute) lent us to observe the high regularity of the internal solitons arrival to the mooring. These solitons have been related with the internal waves released over the Camarinal Sill (e.g. Vázquez et al., 2008) and they would take $\sim 17$ hours to reach the NW Alborán Sea, depending on several factors, i.e. the stratification. The interface depth has been related to the local and remote atmospheric forcing, while during westerlies/low MSLP the interface reached the shallowest thermistors; during easterlies/high MSLP it was deepened. Although internal activity has been observed during easterlies events, the interface deepening would not allow fertilizing the photic layer. Satellite imagery along with drifter's trajectories depicted the upwelling position and they confirmed the high retention capacity of the area.
\end{abstract}

Key words: north-western Alborán Sea, Atlantic Jet, atmospheric forcing, interface, upwelling

Acknowledgments: This work has been supported by the Spanish National Research Plan through the project MEGAN: CTM2013-49048, and by the European Union's Interreg VA-España - Portugal (POCTEP) 2014-2020 project OCASO (0223_OCASO_5_E). Marina Bolado-Penagos and Iria Sala were supported by a grant of the FPI fellowship program. 


\section{References:}

Macías, D., Bruno, M., Echevarría, F., Vázquez, A. and García, C.M., (2008). Meteorologically-induced mesoscale variability of the North-western Alboran Sea (southern Spain) and related biological patterns. Estuarine Coastal and Shelf Science, 78, 250-266.

Sarhan, T., García-Lafuente, J., Vargas, M., Vargas, J.M. and Plaza, F., (2000). Upwelling mechanisms in the northwestern Alboran Sea. Journal of Marine Systems, 23, 317-331.

Vázquez, A., Bruno, M., Izquierdo, A., Macías, D. and Ruiz-Cañavate, A., (2008). Meteorologically forced subinertial flows and internal wave generation at the main sill of the Strait of Gibraltar. Deep-Sea Research Part I: Oceanographic Research Papers, 55, 1277-1283. 


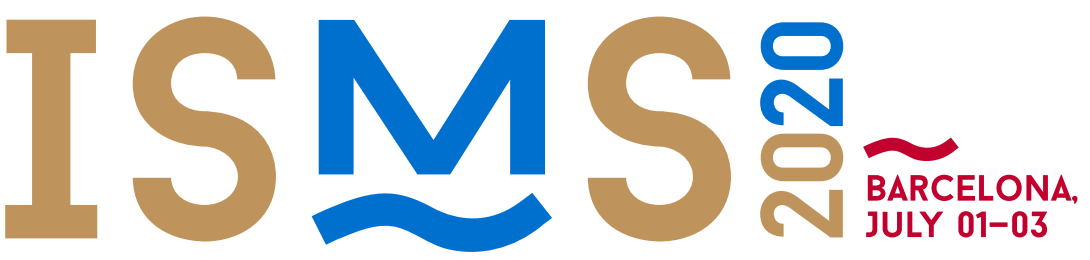

VII INTERNATIONAL SYMPOSIUM ON MARINE SCIENCES

\section{INTERNATIONAL SYMPOSIUM ON MARINE SCIENCES}

\section{POSTER COMMUNICATIONS}



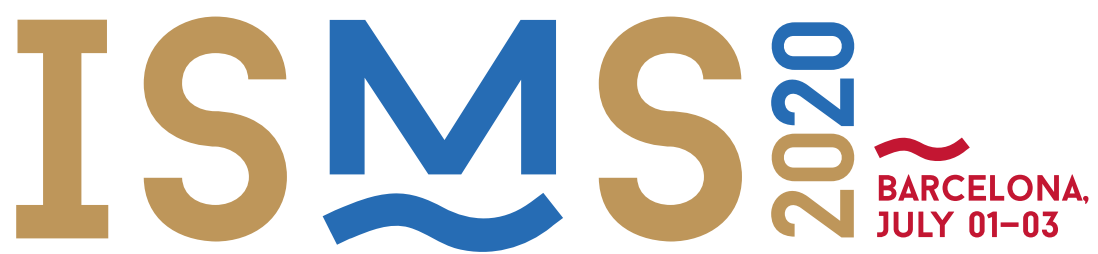

VII INTERNATIONAL SYMPOSIUM ON MARINE SCIENCES

\section{POSTER \\ COMMUNICATIONS}

CHEMICAL

OCEANOGRAPHY

AND BIOGEOCHEMISTRY 


\title{
TEMPORAL VARIABILITY OF DIFFUSIVE NUTRIENT VERTICAL FLUXES IN THE CAPE GHIR UPWELLING REGION
}

\author{
R. Victoriano*1, Á. Rodríguez-Santana ${ }^{2}$ and Á. Marrero-Díaz \\ ${ }^{1,2}$ Departamento de Física (OFYGA Group), Universidad de Las Palmas de Gran Canaria, Las \\ Palmas de Gran Canaria, SPAIN. \\ rvictorianorojas@gmail.com,angel.santana@ulpgc.es,angeles.marrero@ulpgc.es
}

\begin{abstract}
Our main objective is to analyse the temporal variability of diffusive nutrient fluxes in the Cape Ghir oceanic upwelling region using physical and nutrient data from Atlantic-Iberian Biscay Irish Ocean Biogeochemistry Non Assimilative Hindcast (IBI) and in situ data from cruises. For this study, we used CTD-ADCP and nutrient data from the PROMECA cruise that was carried out from 18th to 29th October 2010 onboard R/V García del Cid.

The model was validated by comparing the vertical distributions of the nutrients in the model with the data obtained in the oceanographic campaign, showing a similar behavior in those distributions. Once the validation was done, it allowed us to estimate the degree of validity of the model for the vertical distribution of the nutrient concentration in each period. The most significant time scales of variation from 2000 to 2016 were identified. Since the North Atlantic Oscillation (NAO) affects the magnitude of the trade winds responsible for the presence of the upwelling area and its intensity on the coast of Northwest Africa, we focused our interest on three significant years: 2004, 2010 and 2015. In the first year, the winter NAO index is zero, in the second year the NAO index is negative, and in the third year the NAO is positive.
\end{abstract}

It is known that North Atlantic Oscillation (NAO) affects the magnitude of the trade winds causing the Northwest African coastal upwelling. We identified that in years 2004, 2010 and 2015, with different significant NAO indices, a temporal variability of the physical parameters was observed. Focusing our interest on the year 2004, where the NAO is equal to zero but presents greater variability. Therefore, the following temporal analysis was performed with the nutrient fluxes of the region in order to identify some relationship between the anomalies of the NAO with the physical and nutrient data of the region. For the calculation of the vertical turbulent diffusive flows, the double diffusion processes and the vertical flow shear have been used to get the vertical diffusion coefficient.

Key words: Upwelling, Mixing processes, North Atlantic Oscillation (NAO)

Acknowledgments: This work was supported by the project FLUXES (CTM2015-69392C3-3-R) funded by the Spanish National Research Program. 

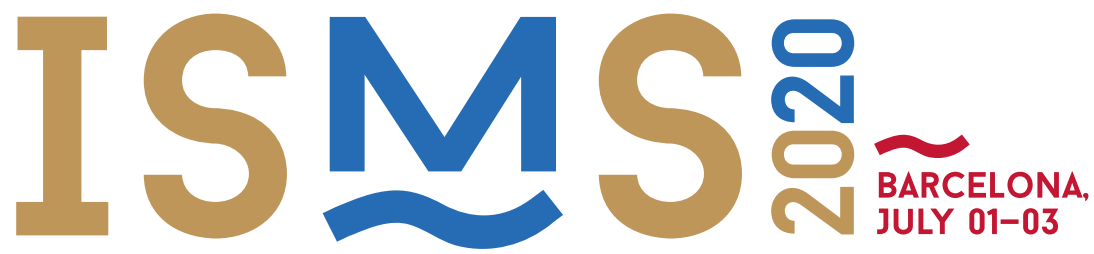

VII INTERNATIONAL SYMPOSIUM ON MARINE SCIENCES

\section{POSTER COMMUNICATIONS}

\section{CITIZEN SCIENCE AND THE SEA: CHALLENGES AND OPPORTUNITIES}




\title{
CITIZEN SCIENCE FOR DISCLOSING SPONGE-GRAZER INTERACTIONS
}

\author{
Berta Pintó $^{1}$ and Lucía Pita ${ }^{2}$ \\ ${ }^{1}$ University of Barcelona, Department of Animal Biology, Barcelona, SPAIN. \\ bertapinto.93@gmail.com \\ ${ }^{2}$ GEOMAR Helmholtz Centre for Ocean Research, Marine Ecology, Research \\ Unit Marine Symbiosis, Kiel, GERMANY. \\ lpita@geomar.de
}

\begin{abstract}
Citizen-science projects (CSP) allow monitoring large areas, performing longterm surveys and collecting information on versatile topics and variables. However, observer training or detection probability may introduce bias in the data. We evaluated the application of a CSP to investigate the impact of grazing by sea slugs on sponges with two main aims: (i) gain data from larger areas and time points and (ii) use the sea slugs, colorful animals that bring the attention of many non-professional drivers, as flagship to increase awareness about the role of sponges in the ecosystem. We launched a pilot study on the sponge Aplysina aerophoba and its grazer Tylodina perversa. We used the records from the GROC organization (occurrences over year) as initial data and their webpage and social media as advertising platform. In addition, we contacted 25 different organizations (diving centers and research institutions) from four countries, both in the Atlantic Ocean and the Mediterranean Sea, and created a project webpage www.biteasponge.com. We designed two protocols for getting quantitative data and including more variables relevant for our research question. Available data from GROC revealed non-significant patterns of adult $T$. perversa abundance by depth or season, but higher abundances in autumn. Observations of eggs and copulation were significantly more abundant in autumn. The new data received due to the CSP contained more information in all the biological and ecologically relevant variables than initial data. However, we found problems in assessing data quality and establishing a stable participation. This pilot study revealed that the collaboration with diving clubs is key to provide training and engage volunteers. We are currently working on promoting volunteer-scientist exchanges and expand the project to other areas and sea slug-sponge interactions.
\end{abstract}

Key words: Citizen-science, Grazing, Benthos, Tylodina perversa, Aplysina aerophoba

Acknowledgments: We thank GROC organization for kindly providing the opisthobranch data to evaluate the feasibility of the CSP and discover first patterns of distribution. We thank to all those clubs, organizations and individuals who have been interested in this 
project and collaborated spreading it, collecting data and offering their availability for talks, queries or doubts. 


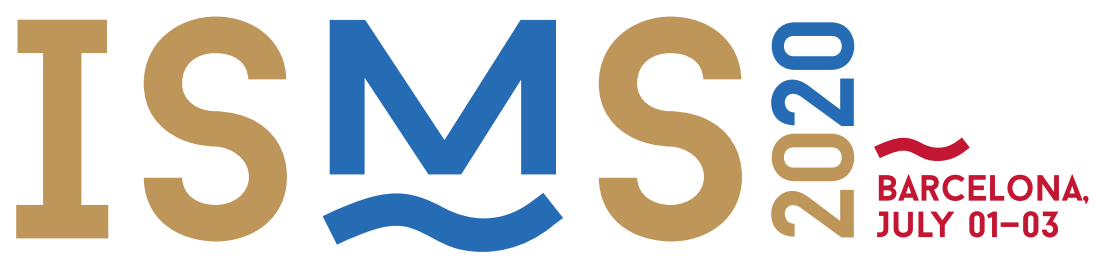

VII INTERNATIONAL SYMPOSIUM ON MARINE SCIENCES

\section{POSTER \\ COMMUNICATIONS}

\section{CLIMATE CHANGE AND THE OCEAN}




\title{
EXPLORING DEEP CIRCULATION PROXIES FOR THE LAST GLACIAL-INTERGLACIAL TRANSITION IN THE ALBORAN SEA
}

\author{
A. Merchán*1, J. Frigola ${ }^{1}$, J.N. Pérez-Asensio ${ }^{1,2}$ and I. Cacho ${ }^{1}$ \\ ${ }^{1}$ GRC Geociències Marines, Departament de Dinàmica de la Terra i de l'Oceà, Facultat de \\ Ciències de la Terra, Universitat de Barcelona, SPAIN. \\ amerchmo7@alumnes.ub.edu,jfrigola@ub.edu,icacho@ub.edu \\ ${ }^{2}$ CEREGE UM34, Aix Marseille Univ, CNRS, IRD, INRAE, 13545 Aix-en-Provence, FRANCE. \\ perez@cerege.fr
}

\begin{abstract}
The last glacial-interglacial transition led a major weakening of the deep overturning cell in the western Mediterranean Sea. This situation allowed the formation of the so-called last Organic Rich Layer (ORL) in the Alboran Sea (15-9 kyr), the westernmost basin of the Mediterranean Sea. A recent study based on benthic foraminifera assemblages counted in deep-sea cores from different water depths of the western Mediterranean Sea has revealed that this ORL event occurred in two phases (PérezAsensio et al., 2020). The first one (15-13 kyr) was the more extreme and affected the oxygen renovation of the water layer at least below $900 \mathrm{~m}$. The second phase (13-9 kyr) was apparently less intense, showing a relative improvement in ventilation at intermediate levels. This study aims to go further in the characterization of these deep and intermediate changes in western Mediterranean circulation by the application of different proxies in an array of cores from the Alboran Sea. In particular, we present a new high-resolution grainsize record (UP10) from core HER-GC-T1 recovered at $659 \mathrm{~m}$ water depth, which corresponds at present to the interphase between Western Mediterranean Deep Water and modified Levantine Intermediate Water masses. The UP10 record shows a significant increase during the last deglaciation, reaching maximum values during the deposition of the ORL. The comparison with a previous published UP10 record from a deep site (Frigola et al., 2008) suggests an enhancement of the circulation intensity at intermediate depths, while remained reduced in deep layers. In addition, XRF core-scanner profiles of redoxsensitive elements have been produced in three cores from $659 \mathrm{~m}, 946 \mathrm{~m}$ and $1313 \mathrm{~m}$ water depths. These results provide new insight into the depth evolution of the reventilation event that ended the last ORL.
\end{abstract}

Key words: Grain size distribution, XRF core-scanner, Last deglaciation, Mediterranean thermohaline circulation

Acknowledgements: This study has received funding from the European Research Council (ERC) through the ERC-Consolidator project TIMED (Grant Agreement No. 683237). 


\section{References:}

Frigola, J., Moreno, A., Cacho, I., Canals, M., Sierro, F.J., Flores, J.A. and Grimalt, J.O. (2008). Evidence of abrupt changes in Western Mediterranean Deep Water circulation during the last 50 kyr: A highresolution marine record from the Balearic Sea. Quaternary International, 181(1), 88-104.

Pérez-Asensio, J.N., Frigola, J., Pena, L.D., Sierro, F.J., Reguera, M.I., Rodríguez-Tovar, F.J., ... Cacho, I. (2020). Changes in western Mediterranean thermohaline circulation in association with a deglacial Organic Rich Layer formation in the Alboran Sea. Quaternary Science Reviews, 228, 106075. 


\title{
PAST CHANGES IN THE WESTERN MEDITERRANEAN OCEANOGRAPHY FROM NEODYMIUM ISOTOPE RATIOS
}

\author{
J. Frigola*1, L.D. Pena ${ }^{1,2}$, A. Català1 ${ }^{1}$, J.N. Pérez-Asensio ${ }^{1,3}$, E. García-Solsona ${ }^{1}$, \\ S.L. Goldstein ${ }^{2}$, F. Lirer ${ }^{4}$ and I. Cacho ${ }^{1}$ \\ ${ }^{1}$ GRC Geosciències Marines, Dept.de Dinàmica de la Terra i de l'Oceà, Facultat de Ciències de la \\ Terra, Universitat de Barcelona, E-08028 Barcelona, SPAIN. \\ jfrigola@ub.edu,lpena@ub.edu,al_catala@ub.edu,e.garcia@ub.edu,icacho@ub.edu \\ ${ }^{2}$ Lamont-Doherty Earth Observatory of Columbia University, Palisades, NY 10964, USA. \\ steveg@ldeo.columbia.edu \\ ${ }^{3}$ CEREGE UM34, Aix Marseille Univ, CNRS, IRD, INRAE, 13545 Aix-en-Provence, FRANCE. \\ perez@cerege.fr \\ ${ }^{4}$ Institute for Coastal Marine Environment (IAMC) - CNR, 80133 Naples, ITALY. \\ fabrizio.lirer@cnr.it
}

\begin{abstract}
The Mediterranean thermohaline circulation, by contributing with warm and salty waters into the North Atlantic region, may also significantly impact the global thermohaline circulation, which is a key component of the climate system. In fact, oscillations in the western Mediterranean thermohaline circulation have been described in synchrony with North Atlantic climate changes during the last glacial cycle. Especially, significant oceanographic reorganizations took place in the western Mediterranean thermohaline circulation during the last major glacial/interglacial transition mainly associated with the deglacial sea level rise and the establishment of more stable atmospheric conditions.
\end{abstract}

Benthic $\delta^{13} \mathrm{C}$ and grain-size records from different sediment cores showed drastic reductions in ventilation of the Western Mediterranean deep basin related to enhanced water column stratification during deglacial sea level rise. Subsequently, these conditions led to the formation of the last Organic Rich Layer (ORL) in the Alboran Sea.

In addition, integration of benthic foraminifera assemblages and TOC records from three sediment cores distributed between $900 \mathrm{~m}$ and $2400 \mathrm{~m}$ depth corroborate the deterioration of deep water ventilation conditions during this period, while evidencing an earlier reventilation of the intermediate layer. However, the deepest part of the basin did not reventilated until the early Holocene, when deep-water convection in the Gulf of Lion was resumed during a major cold event with intensified north-westerly winds.

In order to investigate such changes of the western Mediterranean thermohaline circulation we use Neodymium isotopic ratios $\left(\varepsilon_{\mathrm{Nd}}\right)$ measured on Fe-Mn encrusted planktonic foraminifera as a conservative water mass mixing proxy in four sediment cores from the Alboran Sea covering the 650-2400 m depth range and the last $22 \mathrm{kyr}$. Our results clearly identify a different oceanographic behaviour between intermediate and deep levels during 
the deposition time of the ORL, denoting important readjustments of the western Mediterranean thermohaline circulation during this key climate transition.

Key words: Neodymium isotopes, Mediterranean water masses, Thermohaline circulation, Last deglaciation

Acknowledgments: This work has been supported by ERC Consolidator project TIMED (Grant Agreement No. 683237) and the Spanish research project CHIMERA (CTM201675411-R). 


\title{
MAY DEEP LEARNING CONTRIBUTE TO DOWNSCALING TECHNIQUES?
}

\author{
Peña-Izquierdo J., Gómez C. and Pérez-Zanón N. \\ Barcelona Supercomputing Center (BSC), Barcelona, Spain \\ jesus.pena@bsc.es
}

\begin{abstract}
:
Climate reanalysis has become an essential tool in climate change analysis and it is widely used as the reference to validate climate simulations. A reanalysis is a synthetic estimate of the climate state produced by a numerical weather prediction that assimilates as much as possible observations. Although a reanalysis provides a gridded dataset, including even hundreds of geophysical variables with hourly resolution from the present day to several decades in to the past, its spatial resolution is limited by computational resources. Modern reanalysis, like ERA5 from the ECMWF, provides a resolution of $25 \mathrm{~km}$ which may be insufficient for a broad list of applications.
\end{abstract}

Classical downscaling techniques aim to solve this issue inferring higher resolution patterns usually through the implementation of multivariate regressions or analogues (Ribalaygua et al. 2013; Yiou et al. 2013; Terzago et al. 2018; Perez-Zanon et al. 2020). However, impressive recent progress in the field of computer vision through the implementation of deep neural networks has opened a new world of possibilities (Vandal et al. 2017, BañoMedina et al. 2019).

In this study, we use a selected set of variables from the ERA5 dataset to compare different classical downscaling methods with some common deep learning architectures commonly used in computer vision such as supervised convolutional neural networks and generative models. This work aims to provide an exploratory analysis of the possibilities of these recent techniques to pave the road for more advanced approaches capable of competing with the state of the art downscaling methods.

Key words: Downscaling, Neural networks, Reanalysis

Acknowledgments: Part of this work was performed in the framework of the MEDSCOPE 
(MEDiterranean Services Chain based On climate PrEdictions) ERA4CS project (grant agreement no. 690462) funded by the European Union

\section{References:}

Baño-Medina, J., Manzanas, R., and Gutiérrez, J. M.: Configuration and Intercomparison of Deep Learning Neural Models for Statistical Downscaling, Geosci. Model Dev. Discuss., https://doi.org/10.5194/gmd-2019-278, in review, 2019.

Pérez-Zanón N., Caron LP., Alvarez-Castro C., von Hardenberg J., LLedo L., Manubens N., Sanchez-Garcia E., van Schaeybroeck B., Torralba V. and Verfaillie D. (2020). CSTools: Assessing Skill of Climate Forecasts on Seasonal-to-Decadal Timescales. R package version 3.0.0. https://CRAN.R-project.org/package $=$ CSTools [Last accessed 03/12/2020]

Ribalaygua, J., Torres, L., Pórtoles, J. et al. Description and validation of a two-step analogue/regression downscaling method. Theor Appl Climatol 114, 253-269 (2013). https://doi.org/10.1007/s00704-013-0836-x

Terzago, S., Palazzi, E., \& Von Hardenberg, J. (2018). Stochastic downscaling of precipitation in complex orography: a simple method to reproduce a realistic fine-scale climatology. Hazards Earth Syst. Sci, 18, 2825-2840. https://doi.org/10.5194/nhess-18-2825-2018

Vandal, T., Kodra, E., and Ganguly, A. R.: Intercomparison of Machine Learning Methods for Statistical Downscaling: The Case of Daily and Extreme Precipitation, arXiv:1702.04018 [stat], http://arxiv.org/abs/1702.04018, arXiv: 1702.04018, 2017.

Yiou, P., Salameh, T., Drobinski, P., Menut, L., Vautard, R., \& Vrac, M. (2013). Ensemble reconstruction of the atmospheric column from surface pressure using analogues. Climate Dynamics, 41(5-6), 1333-1344. https://doi.org/10.1007/s00382-012-1626-3 


\title{
PREDICTING HABITAT USE BY THE ARGENTINE HAKE MERLUCCIUS HUBBSI IN A WARMER WORLD: INFERENCES FROM THE MIDDLE HOLOCENE
}

\author{
M. Bas ${ }^{1,2}$, M. Salemme ${ }^{1,3}$ E. J. Green ${ }^{4}$, F. Santiago ${ }^{1}$, C. Speller ${ }^{4,5}$, M. Álvarez ${ }^{1}$, I. Briz \\ i Godino ${ }^{1,6,7}$ and L. Cardona ${ }^{2}$ \\ 1. Centro Austral de Investigaciones Científicas (CADIC-CONICET), Ushuaia, \\ ARGENTINA. \\ mbaslpez@gmail.com,monica.salemme@gmail.com,ersant2@gmail.com, \\ myrianalvarez@gmail.com,ibrizgodino@gmail.com \\ 2. Department of Evolutionary Biology, Ecology and Environmental Science, \\ Biodiversity Research Institute (IRBio), University of Barcelona, Barcelona, SPAIN. \\ luis.cardona@ub.edu \\ 3. ICSE, Universidad Nacional de Tierra del Fuego, Ushuaia, ARGENTINA \\ 4. BioArCh, Department of Archaeology, University of York, York, UNITED KINGDOM \\ eg715@york.ac.uk \\ 5. Department of Anthropology, University of British Columbia, Vancouver, BC, CANADA \\ speller@palaeome.org \\ 6. Department of Archaeology, University of York, York, UNITED KINGDOM. \\ 7. P. Rockefeller Visiting Scholar. DRCLAS at Harvard University. Cambridge, MA. \\ UNITED STATES OF AMERICA.
}

\begin{abstract}
Fish skeletal remains recovered from two archaeological sites dated in the Middle Holocene of Tierra del Fuego (Argentina) were analysed to describe habitat use patterns by hake in the past and predict changes in a warmer world. Mitochondrial DNA was successfully extracted and amplified from 42 out of 45 first vertebra from ancient hake and phylogenetic analysis assigned all haplotypes to Argentine hake (Merluccius hubbsi). According to osteometry, the Argentine hake recovered from the archaeological site were likely adults ranging 37.2 to $58.1 \mathrm{~cm}$ in standard length. $\mathrm{C}$ and $\mathrm{N}$ stable isotope analysis showed that currently Argentine hake use foraging grounds deeper than those of Patagonian blenny and pink cusk-eel. Argentine hake, however, had a much broader isotopic niche during the Middle Holocene, when a large part of the population foraged much shallower than contemporary pink cusk-eel. The overall evidence suggests the presence of large numbers of Argentine hake onshore Tierra del Fuego during the Middle Holocene, which allowed exploitation by hunter-gatherer-fisher groups devoid of fishing technology. Interestingly, average SST off Tierra del Fuego during the Middle Holocene was higher than currently $\left(11^{\circ} \mathrm{C}\right.$ vs $\left.7^{\circ} \mathrm{C}\right)$ and matched SST in the current southernmost onshore spawning aggregations, at latitude $47^{\circ} \mathrm{S}$. This indicates that increasing SST resulting from global warming will likely result into an increased abundance of adult Argentine hake onshore Tierra del Fuego, as during the Middle Holocene. Furthermore, stable isotope ratios from mollusc shells confirmed a much higher marine primary productivity during the Middle Holocene off Tierra del Fuego.
\end{abstract}


Key words: Hake, Osteometry, Stable isotopes, Tierra del Fuego, Zooarchaeology

Acknowledgments: Special thanks are due to Matias Pardo from San Arawa fishing company for his help in obtaining modern Southern hake samples. We acknowledge Dr. Begoña López Arias, Universidad Autónoma de Madrid, for her assistance in designing and testing the genetic primers. We are very grateful to Pilar Rubio who helped us with isotopic analyses at Centres Cientifics $i$ Tecnologics de la Universitat de Barcelona (Barcelona, Spain). The ancient genetic analysis was supported by the UK Arts and Humanities Research Council (grant number AH/N005015/1) and the Leverhulme Trust (through a Philip Leverhulme Prize to CS). This paper was also supported by the following projects: PIP CONICET 0409-13 and PICT 2012-1944 to MS. 


\title{
GRAIN-SIZE AND BULK-SEDIMENT GEOCHEMICAL DATA FROM THE MENORCA RISE (WESTERN MEDITERRANEAN SEA) OVER THE PAST 22,000 YEARS
}

\author{
Natalia Bienzobas*1,2, Gianluca Marino ${ }^{1,2,3}$, Ana Bernabeu ${ }^{1,2}$, Stewart Fallon ${ }^{3}$, \\ Alessandro Incarbona ${ }^{4}$, Maider Plaza Morlote ${ }^{1,2,5}$, Daniel Rey ${ }^{1,2}$, Laura Rodríguez \\ Sanz ${ }^{3}$, and Eelco Rohling ${ }^{3,5}$ \\ ${ }^{1}$ Department of Marine Geosciences and Territorial Planning and, University of Vigo, Vigo, Spain. \\ *nbienzobas@alumnos.uvigo.es, gianluca.marino@uvigo.es, bernabeu@uvigo.es, \\ m.plaza.morlote@uvigo.es,danirey@uvigo.es. \\ ${ }^{2}$ CIM-UVIGO, GEOMA, University of Vigo, Vigo, Spain. \\ ${ }^{3}$ Research School of Earth Sciences, The Australian National University, Canberra, Australia. \\ stewart.fallon@anu.edu.au, laura.rodriguez@anu.edu.au, eelco.rohling@anu.edu.au. \\ ${ }^{4}$ Dipartimento di Scienze della Terra e del Mare, Università di Palermo, Palermo, Italy. \\ alessandro.incarbona@unipa.it \\ ${ }^{5}$ Ocean and Earth Science, University of Southampton, National Oceanography Centre, \\ Southampton SO14 3ZH, UK.
}

\begin{abstract}
Palaeoceanographic data from the western Mediterranean Sea have revealed a strong connection with ocean and climate variability in the wider North Atlantic realm, alongside an influence of both climate and erosional processes in Southern Europe and Northern Africa. Through the last and previous glacial-interglacial cycles, an intimate link has been observed between sediment geochemistry and grain-size distributions, and variations in the strength of western Mediterranean deep-water formation along the southern European margin. We present new, high-resolution, and precisely (radiocarbon) dated time series of bulk-sediment and foraminiferal geochemistry, calcium carbonate $\left(\mathrm{CaCO}_{3}\right)$ concentrations, and grain-size data (total and non-carbonate fraction) across the last 22,000 years from Ocean Drilling Program (ODP) Site 975, in the Menorca Rise. The targeted time interval spans the full transition from the Last Glacial Maximum (LGM), through the last glacial termination (T-I), and through the Holocene interglacial. Bulk sediment geochemical proxies (e.g., $\mathrm{Ca} / \mathrm{Ti}$ ratio), $\mathrm{CaCO}_{3}$ concentrations, and grain-size data (e.g., silt/clay ratio, median) exhibit most of their variability across T-I. This variability is superimposed on the overall change between the LGM and the Holocene that is indicated by a decrease in the foraminiferal stable oxygen isotopes. Specifically, we note that decreases in the $\mathrm{Ca} / \mathrm{Ti}$ ratio and $\mathrm{CaCO}_{3}$ concentrations match increases in the median of the sediment grain-size distribution and in the silt/clay ratio in both total and non-carbonate fractions. We will discuss this new evidence from the Menorca Rise in the context of previously published sedimentological and geochemical data from the wider western Mediterranean Sea.
\end{abstract}

Key words: Mediterranean Sea; sedimentology; bulk sediment geochemistry; palaeoclimatology; 
glacial termination I. 


\title{
U/MN AS A NEW INDICATOR OF CHANGES IN WESTERN MEDITERRANEAN THERMOHALINE CIRCULATION SINCE THE LAST GLACIAL MAXIMUM
}

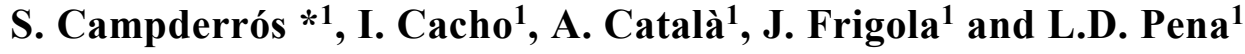 \\ ${ }^{1}$ GRC Geociències Marines, Departament de Dinàmica de la Terra i de l'Oceà, Facultat de \\ Ciències de la Terra, Universitat de Barcelona, Carrer Martí i Franques s/n, 08028 Barcelona, \\ SPAIN. \\ saracs1321@gmail.com,icacho@ub.edu,al_catala@ub.edu,jfrigola@ub.edu,lpena@ub.edu
}

\begin{abstract}
Climatic conditions in the Mediterranean region control the formation of intermediate and deep-water masses. On-going global change has already induced changes in this circulation system, and available models predict its weakening by the end of this century. One of the implications of such a shift is the reduction of oxygen in both intermediate and deep-water masses. Nevertheless, the sensitivity of the system is not fully known, and the lack of data prevents to set its range of natural variability. Here a new geochemical proxy is tested to estimate changes in oxygen content of Mediterranean water masses during past times. The U/Mn index is here measured in the authigenic coating of planktonic foraminifera from two sites in the Alboran Sea (Western Mediterranean Sea), where cores HER-GC-UB-6 (946m water depth) and MD 95-2043(1841m water depth) were collected. The U/Mn ratio serves as a reliable indicator of redox conditions in marine sediments independent of shell matrix variations. Therefore, the U/Mn index measured from these two cores will provide the information for reconstructing the oxygen concentration of deep and intermediate Western Mediterranean waters since the Last Glacial Maximum. The targeted period is particularly relevant since major changes occurred in the Mediterranean thermohaline system in relation to the formation of the last Organic Rich Layer in the Alboran Sea and the Last Sapropel in the Eastern Mediterranean Sea. This study aims to test this relatively new proxy in the context of Mediterranean thermohaline changes and provide a new insight into the natural variability of this circulation system.
\end{abstract}

Key words: Thermohaline circulation, Paleoceanography, Foraminifers, U/Mn, Oxygen content, Western Mediterranean Sea 

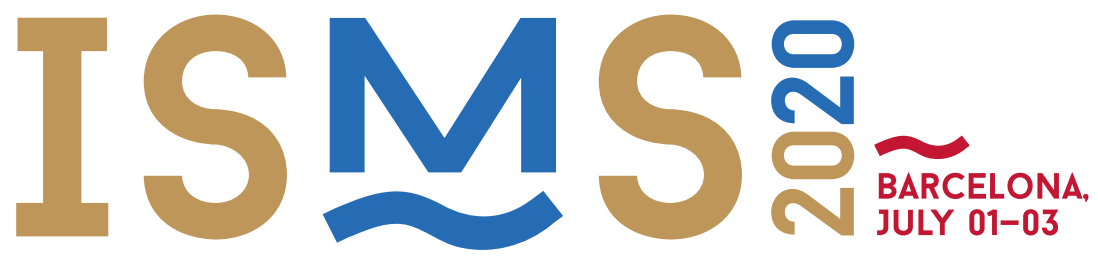

VII INTERNATIONAL SYMPOSIUM ON MARINE SCIENCES

\section{POSTER \\ COMMUNICATIONS}

\section{COASTAL \\ AND ESTUARINE SYSTEMS}




\title{
INTERACTION BETWEEN DIFFERENT NATURE VARIABLES AFFECTING ARID NEBKHA FOREDUNES
}

\author{
Sanromualdo-Collado, A.*1, Gallego-Fernández, J.B. ${ }^{2}$, Delgado-Fernández, I. $^{3}$, \\ Martínez, M.L. ${ }^{4}$, Hesp, P. A. ${ }^{5}$, Ferrer-Valero, N. ${ }^{1}$, O'Keeffe, N. ${ }^{3}$, and Hernández- \\ Calvento, L. ${ }^{1}$
}

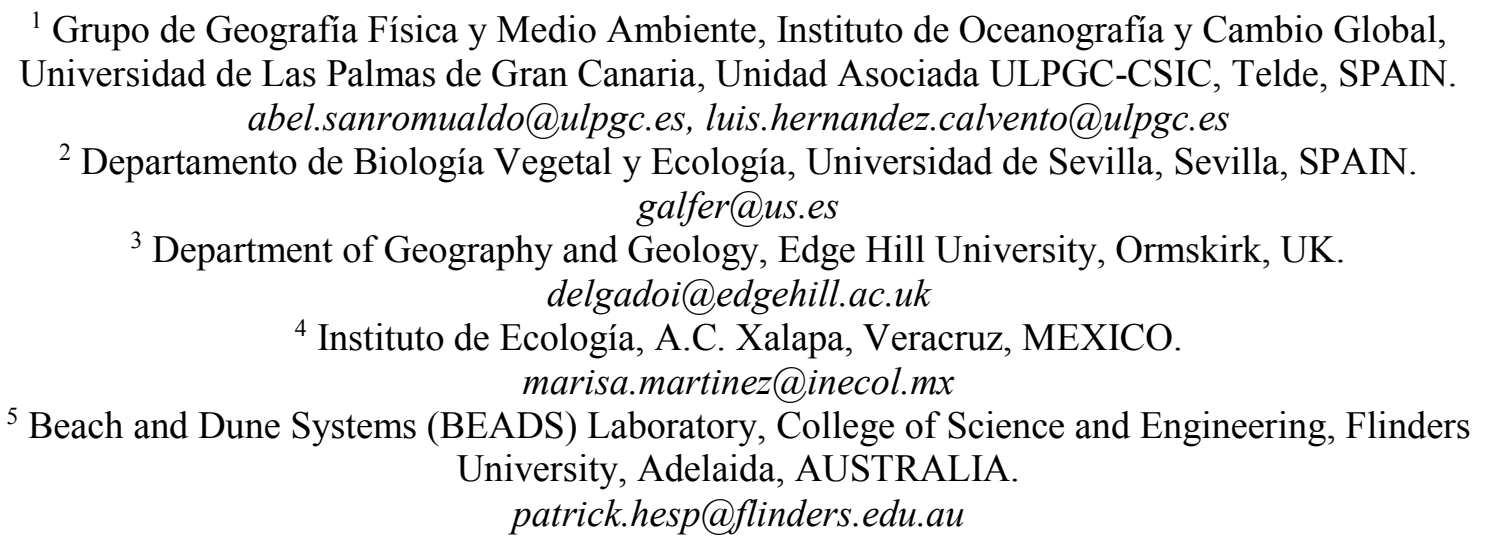

\begin{abstract}
The foredunes of arid dune systems, such as those present in the Canary Islands (Spain), comprise nebkha dunes. These nebkhas are formed by the interaction between aeolian sedimentary dynamics and shrub vegetation, although other variables can influence nebkha formation. In the Canary Islands nebkhas are formed by sand trapping in Traganum moquinii (Hernández-Cordero et al., 2015; Viera-Pérez, 2015). Formed by a set of individual nebkhas and mobile dunes of variable height that control the sand flux inland (HernándezCordero et al., 2012), these arid foredunes are fragile naturally fragmented boundaries between beaches and dunes, so they are essential for protection against coastal erosion, especially in the face of the current climate change. Knowing how certain variables influence others is necessary to carry out effective management over T. moquinii foredunes, protecting them from human impacts and preserving their function as natural protection against coastal erosion (Peña-Alonso et al., 2018).

Based on these premises, data related to nebkha morphology (position, slope, aspect and height), sediment (grain size, \% carbonates, conductivity and relative temperature) and vegetation (species, \% cover and plant mean height) were taken in a representative nebkha located in the foredune at Playa de Famara, Lanzarote. The detailed sampling scale applied, from 120 plots of $0.5 \times 0.5 \mathrm{~m}$., allows us to examine the spatial distribution of measured variables across and inside the nebkha and to analyse spatial relationships between them. As a result, relationships between pairs of variables are evidenced inside nebkha and interaction zones between different variables are determined. Based on these results, new essays are proposed in order to elucidate how T. moquinii interact with surrounding variables.
\end{abstract}

Key words: Arid dune system, Natural variables, Spatial distribution, Protection, Coastal erosion. 
Acknowledgments: This work is a contribution of project CSO2016-79673-R (National R\&D\&i Plan, Spain) co-financed with ERDF funds. First author is beneficiary of a PhD contract of the Spanish Ministry of Economy, Industry and Competitiveness, supported by the European Social Fund (ESF). This article is a publication of the Unidad Océano y Clima of the Universidad de Las Palmas de Gran Canaria, a R\&D\&i CSIC- associate unit.

\section{References:}

Hernández-Cordero, A.I., Hernández-Calvento, L., Pérez Chacón Espino, E., 2015. Relationship between vegetation dynamics and dune mobility in an arid transgressive coastal system, Maspalomas, Canary Islands. Geomorphology 238, 160-176. https://doi.org/10.1016/j.geomorph.2015.03.012

Hernández-Cordero, A.I., Pérez-Chacón Espino, E., Hernández-Calvento, L., 2012. La investigación como soporte de la gestión: el ejemplo de la duna costera (foredune) de Maspalomas (Gran Canaria, Islas Canarias). La gestión Integr. Play. y dunas Exp. en Latinoamérica y Eur. Monogr. la Soc. d'Història Nat. Illes Balear. 19, 289-306.

Peña-Alonso, C., Gallego-Fernández, J.B., Hernández-Calvento, L., Hernández-Cordero, A.I., Ariza, E., 2018. Assessing the geomorphological vulnerability of arid beach-dune systems. Sci. Total Environ. 635, 512-525. https://doi.org/10.1016/j.scitotenv.2018.04.095

Viera-Pérez, M., 2015. Estudio detallado de la duna costera de Maspalomas (Gran Canaria, Islas Canarias): interacción «Traganum moquinii» - dinámica sedimentaria eólica en un entorno intervenido. Recomendaciones de cara a su gestión. PhD Thesis. Universidad de Las Palmas de Gran Canaria. 


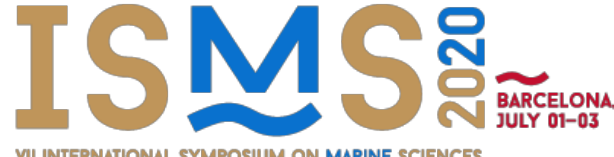 \\ VII INTERNATIONAL SYMPOSIUM ON MARINE SCIENCES
}

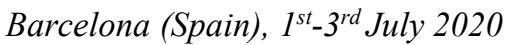

\section{RECENT COASTAL CHANGES IN THE PROVINCE OF CASTELLÓN (WESTERN MEDITERRANEAN SEA)}

\author{
M. Roca ${ }^{1}$, I. Rodríguez-Santalla ${ }^{2}$, B. Martínez-Clavel ${ }^{1}$, M. Pablos ${ }^{2}$, \\ L. Moreno-Blasco ${ }^{3}$, A.M. Blázquez ${ }^{1}$ \\ ${ }^{1}$ Environmental and Marine Sciences Research Institute, Catholic University of Valencia, \\ Valencia, SPAIN. \\ mar.roca@mail.ucv.es,borjamcv@gmail.com,ana.blazquez@ucv.es \\ ${ }^{2}$ Universidad Rey Juan Carlos, Móstoles (Madrid), SPAIN. \\ inmaculada.rodriguez@urjc.es,miriam_pm23@hotmail.es \\ ${ }^{3}$ Universidad Politécnica de Madrid, Madrid, SPAIN. \\ luisjuan.moreno@upm.es
}

\begin{abstract}
This research analyses coastal changes between the harbours of Castellón and Sagunto from 1956 to present day. Coastline data from different years has been obtained from aerial photographs, satellite images and orthophotos in order to estimate and compare rates of shoreline advance and retreat. After digitizing the shoreline, statistics were obtained with DSAS software, and the results were analyzed with $\mathrm{R}$ software. Finally, land-use information, provided by Corine Land Cover 2018, was used to study trends and patterns and compare them with coastal evolution. Results indicate a widespread erosional tendency due to human activities, which have limited sediment supply from source areas to the beaches. High rates of accretion are only recorded at places where coastal protection infrastructures, such as dams, jetties and harbours, have been built perpendicular to the longshore current (Crous and Pintó, 2006). An advance of $220 \mathrm{~m}$ was recorded in Burriana harbour, and one of up to $250 \mathrm{~m}$ north of Sagunto harbour. In contrast, retreats of more than $200 \mathrm{~m}$ were found in a number of sites. The artificial nourishment of beaches had a strong influence on the coastline's behavior, specially from 1998 to 2017. Moreover, coastal land uses have changed from agricultural to urban, which resulted in a drastical modification of coastal dynamics (Obiol and Pitarch, 2011). Our results allow predicting the future position of the coastline and identifying interactions with changes in land-use, accommodation spaces along the coast for buffer purposes of the segments that are most vulnerable to erosion. Those accommodation spaces are particularly important to develop integrate coastal zone management (ICZM) programs in order to face the effects of climate change over the coastline (Rodríguez-Santalla et al., 2009).
\end{abstract}

Key words: Coastal evolution, Beach erosion, Human impact, Castellón, Western Mediterranean Sea

\section{References:}

Crous, A. and Pintó, J. (2006). Evolución de la playa de Sa Riera (Cap de Begur, Costa Brava) en los últimos 50 años. Investigaciones geográficas, 39, 119-130.

Obiol, E. and Pitarch, M.D. (2011). El litoral turístico valenciano: intereses y controversias en un territorio tensionado por el residencialismo. Boletín de la Asociación de Geógrafos Españoles, 56, 177-200.

Rodríguez-Santalla, I., Montoya, I., Sánchez, M.J. and Carreño, F. (2009). Geographic Information Systems applied to Integrated Coastal Zone Management. Geomorphology, 107, 100-105. 


\title{
NEW APPROACH TO THE SEDIMENTARY CHARACTERIZATION OF THE INTERTIDAL SAND BANKS: THE CASE OF THE RIAS ALTAS (NW OF IBERIAN PENNINSULA)
}

\author{
J.D. Cerdeira-Arias' ${ }^{1}$, J. Otero ${ }^{2}$, X.A. Álvarez-Salgado ${ }^{2}$, A. Mena ${ }^{3}$ and M.A. \\ Nombela*3 \\ ${ }^{1}$ Xefatura Territorial da Consellería do Mar, Celeiro, Viveiro, Lugo, SPAIN \\ jose.daniel.cerdeira.arias@xunta.gal \\ ${ }^{2}$ Instituto de Investigaciones Marinas (IIM-CSIC), Vigo, SPAIN \\ jotero@iim.csic.es,xsalgado@iim.csic.es \\ ${ }^{3}$ Departamento de Xeociencias Mariñas. Fac. de Ciencias do Mar, Uni. de Vigo, Vigo, SPAIN \\ anxomena@uvigo.gal,mnombela@uvigo.es
}

\begin{abstract}
Intertidal sandy ecosystems are highly variable, geochemically reactive and biologically productive interfaces between atmospheric, terrestrial and aquatic environments. In this study we carry out a cross-comparison of the grain-size and geochemical composition of the substrate sediments of near 60 shellfish harvesting sandbanks. The analyse area represent about $1250 \mathrm{~km}^{2}$ along the Rias Altas, (NW Iberian Peninsula). Multivariate and Principal Component Analysis (PCA) were carried on grain size distribution, calcium carbonate content, organic matter, $\mathrm{Si}$ and $\mathrm{Al}$ oxides. Trace metals were used to study the spatial structure of sandbanks in order to characterise the intertidal sediment and to identify the parameters driving the obtained clustering. The multivariate analysis revealed that the sandbanks are organised around four clusters that do not depend exclusively on the embayment where they were located, but characterized by the imprint of the Cabo Ortegal complex material (with high levels of $\mathrm{MgO}, \mathrm{Mn}, \mathrm{Cr}, \mathrm{Ni}, \mathrm{V}$ and $\mathrm{Fe}_{2} \mathrm{O}_{3}$; $\mathrm{Ria}$ de Ortigueira) or by the imprint of the Ollo de Sapo and Manto de Mondoñedo influence (high levels of $\mathrm{SiO}_{2}, \mathrm{Rb}, \mathrm{K}_{2} \mathrm{O}$ and $\mathrm{Ba}$; the rest of the embayments). The cluster analysis also separated the sandbanks with higher terrestrial influence in the inner part of the embayments (with high levels of $\mathrm{Al}_{2} \mathrm{O}_{3}, \mathrm{Zn}, \mathrm{Ba}$ and $\mathrm{TiO}_{2}$ ) from those with higher marine influence, which were located in the outer part (with high levels of $\mathrm{Sr}, \mathrm{CaO}$ and $\mathrm{CaCO}_{3}$ ). Overall, the compositional and textural distribution of the sediments in the shellfish banks of the Rias Altas is a direct consequence of the environmental conditions that usually can be affected by the anthropogenic influence in this coastal zone.

Besides, attending to the statistical analysis of this multiproxy dataset, the results of this work reveal this approach as a new powerful tool to the sandbanks characterization.
\end{abstract}

Key words: Rias Altas, Multivariate analysis, Sediment geochemistry, Grain size, Sandbanks characterization.

Acknowledgments: this study was founded by the Conselleria do Mar (Xunta de Galicia) and partially by the help GRC ED431 C 2017/55 (Xunta de Galicia) 


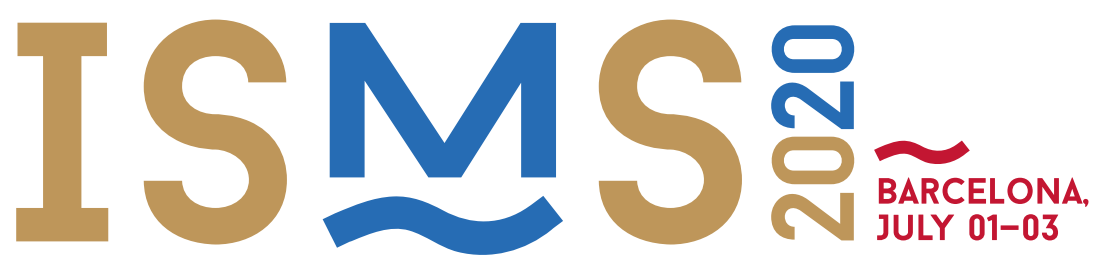

VII INTERNATIONAL SYMPOSIUM ON MARINE SCIENCES

\section{POSTER \\ COMMUNICATIONS}

\section{LIVING \\ RESOURCES}




\title{
FEEDING HABITS OF ATLANTIC BLUEFIN TUNA IN THE STRAIT OF GIBRALTAR
}

\author{
A. Magro, A. Medina and J.L. Varela \\ Departamento de biología, Facultad de ciencias del Mar y Ambientales, Campus de Excelencia \\ Internacional del Mar (CEI-Mar), 11510, Puerto Real, Cádiz, Spain. \\ ana.magro@uca.es; antonio.medina@uca.es; joseluis.varela@uca.es
}

\begin{abstract}
The Strait of Gibraltar is home to a diversity of fish species among which the Atlantic bluefin tuna (ABFT) plays a key role delineating the ecosystem. The ABFT is a large pelagic teleost broadly distributed across the North Atlantic and the Mediterranean Sea. Significant commercial catches of ABFT on a regular (monthly) basis are indicative of the presence of ABFT all year in the Strait of Gibraltar. The knowledge of ABFT feeding habits is essential for the understanding of the role of this species in the food web, as well as for the proper management of the resource and the ecosystem preservation. Stomach content analysis (SCA) is a traditional methodology in fish ecology to determine the diet composition. To investigate ABFT feeding patterns in the Strait of Gibraltar, stomachs were collected from 50 individuals, ranging between 130 and $240 \mathrm{~cm}$ in straight fork length. caught by baitboat and green stick. The stomach contents were analyzed in the laboratory using a stereoscopic microscope and specific identification guides. The SCA indicated that crustaceans were the most important group of prey $(\% \mathrm{AI}=87.03)$, followed by fish $(\% \mathrm{AI}=12.85)$ and cephalopods $(\% \mathrm{AI}=0.10)$. Among crustaceans, Sergia robusta was the main prey in terms of alimentary index $(\% \mathrm{AI})$, frequency of occurrence $(\% \mathrm{O})$ and weight $(\% \mathrm{~W})$. The family Stomiidae was the most representative fish taxon. The graphical method of Amundsen showed that ABFT displays a generalist behaviour for most of the preys, which have low frequency of occurrence and low prey-specific abundance, and hence can be considered unimportant and rare.
\end{abstract}

Key words: Thunnus thynnus, feeding habits, stomach content

\section{Acknowledgments}

A. Magro was financed by the University of Cádiz with a FPI fellowship (FPI-UCA). Thank the crews of J.C. Mackintosh for tuna samples. This research was funded by the Spanish Ministry of Economy and Competitiveness (VORATUN, project \#CTM2017-82808-R and the CEI·MAR Foundation (project \#CEIJ-C03.1). 


\title{
PRELIMINARY STUDY ON THE GROWTH OF THE CLAM Scrobicularia plana (da Costa, 1778) IN THE BAY OF CÁDIZ (SOUTHWEST OF SPAIN)
}

\author{
Caderno, A. *1, Hortas, F. ${ }^{2}$, and Cabrera-Castro, R. $^{2}$ \\ Department of Biology, Faculty of Marine and Environmental Sciences, Cadiz University, \\ SPAIN. \\ anyellc9402@gmail.com \\ ${ }^{2}$ University Institute of Marine Research (INMAR), Campus of International Excellence of the Sea \\ (CEIMAR), 11510 Puerto Real, Cádiz, SPAIN. \\ francisco.hortas@uca.es, reme.cabrera@uca.es
}

\begin{abstract}
Scrobicularia plana is a species are highly appreciated gastronomically in the Bay of Cádiz, as indicating their great demand and commercial interest in the area. Moreover, the high rates of unemployment in the region have meant that for years, shellfishing has been a complementary activity. The number of illegal shellfish catchers seems has far exceeded the number of legal shellfish catchers. The starting hypothesis for this work was that the average capture sizes are lower than those established by the legislation in force in Andalusia. In addition this activity, although regulated, takes place even closed periods. On the other hand, this species is a filtering species, and since they are collected illegally, they do not go through purification and dispatch centres, what could be a public health problem. The objective of this work was to determine the actual average sizes of illegal catches for this species in usual shellfish areas of the Bay of Cádiz, to estimate the growth of the species. Samples were obtained monthly from February to July, 2019 (474 specimens), through the purchase from the shellfish catchers. Biometric analyzes were conducted and the dry weight (DW) and the ash-free dry weight (AFDW) were obtained. In parallel, growth marks or rings were counted for each size class. Samples were found with sizes smaller than those established by current legislations $(12.24 \%)$. Using the ring count, a growth pattern was established taking into account the number and the increase seen in them. The most frequent ring numbers observed were 15 and 14, which corresponded to an average length of $38.24 \mathrm{~mm}$. The parameters obtained from the Von Bertalanffy growth model are in agreement with those found by other authors in the same latitudes $\left(L_{\infty}=44.88, k=0.25\right.$ y $\left.t_{\circ}=6.19\right)$. New data from later months is still being processed.
\end{abstract}

Key words: Bay of Cadiz, Bivalves, Minimum sizes, Shellfishing, Scrobicularia plana

Acknowledgments: To thank the different researchers of the Marine Research University Institute (INMAR) and the University of Cádiz (UCA) who collaborated with the work. Also a special thanks to the students of the UCA: Carlos, Raúl, Alberto, Jaime, Jessica and Lucía for their help in the process of sampling and biometric analysis. 


\title{
DIGESTIVE ENZYME ACTIVITY IN FASTING WRECKFISH (POLYPRION AMERICANUS) LARVAE
}

\author{
E. Pérez*1, M. Pérez ${ }^{1}$, C. Batista ${ }^{2}$, B. Álvarez-Blázquez ${ }^{1}$ and L. Ribeiro $^{2}$ \\ ${ }^{1-}$ AquaCOV, Instituto Español de Oceanografía, Vigo, SPAIN. \\ evaristo.perez@ieo.es,montse.perez@ieo.es,blanca.alvarez@ieo.es \\ ${ }^{2}$ Aquaculture Research Station, Instituto Português do Mar e da Atmosfera, Olhão, PORTUGAL. \\ conceicao.batista@ipma.pt,lribeiro@ipma.pt
}

\begin{abstract}
The fast growth, late reproductive maturation, high market price and easy manipulation in captivity make wreckfish (Polyprion americanus) one interesting new species for aquaculture. Understanding fish larvae digestive capacity during development contributes to adapt and optimize feeding protocols, so that organisms can efficiently digest food, thus increasing nutrients bioavailability.
\end{abstract}

There is no information on this topic for this species, so the aim of this study was to assess the activities of digestive enzymes during the early larval development stages of wreckfish. Larvae obtained from a mature broodstock kept at the IEO facilities in Vigo were placed in 1000 liter tanks and remained fasted throughout the experiment. Samples for enzymatic activity, length and weight measurements were taken at $0,7,13$ and 16 days after hatching (dah). The digestive enzymes trypsin, amylase, pepsin-like, acid phosphatase, alkaline phosphatase and aminopeptidase were analysed and the activities were expressed as specific activity and total activity.

Trypsin and amylase showed a maximum specific activity at 0 dah, but a constant decrease (up to 50\%) was recorded at 13 dah for trypsin and a drastic drop (10-fold) in amylase at 7 dah and then remained constant until 16 dah. The rest of the enzymes studied showed an opposite pattern, with minimal levels at hatching increasing until reaching maximum activities at 13 dah (pepsin, alkaline phosphatase and aminopeptidase) and 16 dah (acid phosphatase). Regarding the total activity of the studied digestive enzymes, similar response was observed as described for specific activity. An increase until 13 DAH followed by a decrease. This pattern was expected since wreckfish larvae were maintained without food for the whole experimental period.

Recorded activity levels relate to the normal maturation of the digestive system and follow a similar pattern than other marine fish species during the first days of development. Since wreckfish larvae were maintained fasted, the initial increase in digestive activities suggests that energy from endogenous reserves was used to enable larvae to establish exogenous feeding. However, after 13 dah the digestive capacity clearly decreased, possibly due to the depletion of endogenous reserves, till reaching a point of no return. 
Key words: Wreckfish, Enzyme activity, Digestive system, Fasting larvae

Acknowledgments: This work was financed by projects AQUACOV (GAIN, Xunta de Galicia, IN607B 2018/14) and DIVERSIAQUAII (Mar2020-P02M01-0656P). E.P. was funded by GAIN, Xunta de Galicia, through AQUACOV project. 


\title{
STUDY OF STRESS ASSOCIATED WITH TRADITIONAL GERRET OR PICAREL (SPICARA SMARIS) CAPTURED IN THE IBIZA ISLAND
}

\author{
I. Montero ${ }^{1}$, J. Pantoja ${ }^{1}$, A. Sureda ${ }^{2}$, P. Castaño ${ }^{3}$, V. Nuñez-Reyes ${ }^{4}$ and A. Box ${ }^{3}$ \\ ${ }^{1}$ LEADER group, Ibiza, SPAIN. \\ imontero@conselldeivissa.es,jpantoja@conselldeivissa.es \\ ${ }^{2}$ Research Group on Community Nutrition and Oxidative Stress (NUCOX), Department of \\ Fundamental Biology and Health. Palma de Mallorca, SPAIN. \\ antoni.sureda@uib.es \\ ${ }^{3}$ Departmenet de Medi Ambient, Medi Rural i Marí, Consell Insular d'Eivissa, Ibiza, SPAIN. \\ pcastano@conselldeivissa.es,tonibox@conselldeivissa.es \\ ${ }^{4}$ Centre de Recuperació d'Espècies Marines (CREM), Ibiza, SPAIN. \\ cremaquarium@gmail.com
}

\begin{abstract}
In October 2012, the European Regulation (EC) No. 1967/2006 banning bottom trawling at depths less than $50 \mathrm{~m}$ entered into force. This led to the closing of the traditional Spicara smaris fishery in Ibiza and Formentera, which was taking place along the coast between 5 and $30 \mathrm{~m}$ deep. This situation pushed the Balearic Government to ask for the revocation of the regulation and to publish Decree 44/2013 establishing a management plan for artisanal trawling in Balearic waters. Every year the General Director of Rural and Marine Environment publishes a legal settlement establishing the fishing periods and quotas for the season, based on registered sale notes and reports complemented by fishermen declarations on the weight of their catches. The management plan sets the limits and quotas according to the evaluation of a monitoring committee aimed at preventing overfishing. The objective of this study is to determine the antioxidant response of $S$. smaris to the recovery process after specimens are caught in traditional nets. With this aim, 50 individuals of similar size were captured. In a first experiment, a behavioural study was conducted with 20 individuals while in a second experiment blood samples were extracted from 30 individuals divided into three groups (recent capture, day 3 and day 7). The results show that there is an important stress at the time of catching that is progressively normalized during the recovery period. All biomarkers analysed decreased significantly on day 7 from initial values, with a high survival rate of all specimens. Therefore, it can be affirmed that despite suffering a stressful situation during capture, the specimens that are subsequently released do not suffer significant damage that could interfere with their survival.
\end{abstract}

Keywords: Spicara smaris fishery, Fish release, Fish survival, Balearic Islands

Acknowledgements: We appreciate the participation of the local Action Group of Ibiza 
and Formentera (LEADER), which financed this research. We also thank Consell d'Eivissa for facilitating this study, and CREM. 


\title{
ASSESSMENT OF THE HEALTH STATUS OF MARINE ORGANISMS WITH RELEVANCE FOR FISHERIES IN CATALONIA
}

\author{
M. Constenla ${ }^{1}$, A. Soler-Membrives ${ }^{1}$, O. Rodríguez-Romeu ${ }^{1}$, E. Carreras-Colom ${ }^{1}$, \\ F. Padrós ${ }^{1}$, S. Dallarés ${ }^{1}$, M. Carrassón ${ }^{1}$ \\ ${ }^{1}$ Dpt. Biologia Animal, Biologia Vegetal i Ecologia, Universitat Autònoma de Barcelona, \\ Cerdanyola del Vallés, E-08193 Barcelona, Spain. \\ maria.constenla@uab.cat,anna.soler@uab.cat,oriol.rodriguez@uab.cat, \\ ester.carreras.colom@uab.cat,francesc.padros@uab.cat,sara.dallares@uab.cat, \\ maite.carrasson@uab.cat
}

\begin{abstract}
The aim of this study is to evaluate the health status of fish and crustaceans with ecological interest and relevance for local fisheries. The crustaceans Aristeus antennatus (deep-sea red shrimp) and Nephrops norvergicus (norway lobster) and the fish species Mullus barbatus (red mullet) and Engraulis encrasicolus (european anchovy) were collected from three fishing areas of the Catalan Sea. The health status assessment was inferred from (1) variations in the condition indices (K, HSI, GSI, F) of the organisms, (2) parasite communities, (3) presence of histological alterations in different organs (gills, liver / hepatopancreas, digestive tract, spleen, gonad and kidney), and (4) presence of artificial polymers in the digestive tract derived from the potential anthropogenic impact. No clear trends were observed regarding condition indices among the different areas. No parasites nor histological alterations were found in crustaceans. The most abundant parasites in fishes were nematodes and digeneans and significant differences in parasite richness and diversity and abundance of some parasites were found among the different areas. Cysts of unknown aetiology were detected in gills of red mullet and different types of alterations in the hepatic parenchyma were frequently detected in european anchovy. Polymer fibers and fragments were present in $>50 \%$ of the analysed digestive tracts of both crustaceans and fishes. Fiber occurrence and size were particularly higher in crustaceans, especially in deep-sea red shrimp, than in fish. Higher number of fibers were detected in digestive tract of deep-sea red shrimp and red mullet from the fishing area close to the city of Barcelona.

These results seem to indicate that these species do not display evident problems affecting their health status. However, the underlying different stresses associated to changes in the ecological environment (environmental changes, pollution, food availability, fisheries pressure) should not be underestimated.
\end{abstract}

Key words: Aristeus antennatus, Nephrops norvergicus, Mullus barbatus, Engraulis encrasicolus, health status 
Acknowledgments: The project "SOMPESCA" (ARP059/19/00003) is supported by the Catalan Department of Agriculture, Livestock, Fisheries and Food (European Maritime and Fisheries Fund (EMFF)). Authors also thank the fleet of commercial fishing vessels including in the "Federació nacional catalana de confraries de pescadors" for their support. 


\title{
THE DEPLOYMENT OF SKIRTS TO KEEP SEA LICE OUT OF SALMON PENS AFFECTS TO ZOOPLANKTON COMMUNITY STRUCTURE IN THE NORWEGIAN FJORDS
}

\author{
M. Canet-Chaques ${ }^{1}$, V. Fernandez-Gonzalez ${ }^{1}$, N. Casado-Coy ${ }^{1}$, I. Uglem ${ }^{2}$, E.M. \\ Ulvan $^{2}$, P. Klebert ${ }^{3}$, I. Catala-Saez ${ }^{1}$ and P. Sanchez Jerez ${ }^{1}$ \\ ${ }^{1}$ Departamento de Ciencias del Mar y Biología Aplicada. Universidad de Alicante, SPAIN. \\ mireiacanetua@gmail.com; victoria.fernandez@ua.es; ncasadocoy@ua.es; \\ ics44.alu.ua@gmail.com; psanchez@ua.es \\ ${ }^{2}$ Department of Aquatic Ecology - Salmonid fishes. Norwegian Institute for Nature Research \\ (NINA), NORWAY. \\ Ingebrigt.Uglem@nina.no; eva.ulvan@nina.no \\ ${ }^{3}$ SINTEF Ocean, Trondheim, NORWAY. \\ Pascal.Klebert@sintef.no
}

\begin{abstract}
The two sea lice species, Lepeophteirus salmonis and Caligus elongatus, are copepod ectoparasites found on salmonids in seawater. The Norwegian salmon industry has experienced increasing difficulties with salmon lice including increased resistance against chemoterapeutants (Norwegian Food Safety Authority, 2014). Physical protection against sea lice has been carried out using floating plastic enclosures, commonly called skirts, with water intake at 10's of m deep (Naes et al., 2012). The impact of this structure on the pelagic system, particularly on the zooplankton community, is poorly understood. Thus, the objective of this study was to examine whether this physical protection methods against sea lice affect zooplankton communities' structure. The study was carried out at a salmon (Salmo salar) aquaculture facility in the Norwegian fjords in the summer of 2017. Four sites were sampled, three of them within the facility (front, middle and end) and one in a control area. All these points were sampled with and without skirt for four random days each.
\end{abstract}

The results showed an increase up of a 30\% in zooplankton abundance when the skirt was present in comparison with no skirt, showing significant differences. For the most affected groups of zooplankton were echinoderms larvae $(7.34 \times 108 \mathrm{ind} / \mathrm{m} 3$ versus $1.60 \times 108$ ind $/ \mathrm{m} 3 \mathrm{t})$ and gastropods $(8.77 \times 108$ ind $/ \mathrm{m} 3$ versus and $5.51 \times 108)$, which showed significant differences. Skirts as management tool coping with parasitic copepods are needed but they have an impact on the zooplankton communities, which could be some relevance at local scale.

Key words: Aquaculture, Environmental impact, Zooplankton, Sustainable aquaculture, Sea lice 
References: please follow the examples below

Næs, M., Heuch, P.A. and Mathisen, R. (2012). Use of "sea lice skirt" to reduce infestation of salmon lice on farmed salmon. NCE Aquaculture.

Norwegian Food Safety Authority (NFSA), 2014. Report on Sea Lice (Lepeoptheirus salmonis), Oslo, Norway (in Norwegian). 


\title{
COULD MUSSEL AQUACULTURE AFFECTS THE ABUNDANCE OF LEPADOGASTER CANDOLII (RISSO, 1810) DUE TO THE SEDIMENTATION OF ORGANIC MATTER?
}

\author{
I. Català-Saez ${ }^{1}$, N. Casado-Coy ${ }^{1}$, V. Fernandez Gonzalez ${ }^{1}$, C. Sanz-Lazaro ${ }^{1}$, P. \\ Sanchez-Jerez $^{1}$, M. Canet-Chaques ${ }^{1}$, G. Pérez-Benavente ${ }^{3}$, I. Uglem ${ }^{2}$, J. Souza- \\ Troncoso $^{4}$ \\ ${ }^{1}$ Departamento de Ciencias del Mar y Biología Aplicada. Universidad de Alicante, España. \\ ${ }^{2}$ Department of Aquatic - Freshwater ecosystems, Norwegian Institute for Nature Research \\ (NINA), Noruega. \\ ${ }^{3}$ Instituto Galego de Formación en Acuicultura (IGAFA). Pontevedra, España. \\ ${ }^{4}$ Departamento de Ecoloxía e Bioloxía animal. Universidad de Vigo, España.
}

\begin{abstract}
Mussel aquaculture affect the benthic community by the increase of organic matter sedimentation. Additionally, the high levels of production in a small area leads to the accumulation of shells, modifying the complexity of benthic habitats, forcing changes in the benthos and causing an increase in the abundance of macrofauna, especially invertebrates. However, the populations of other groups, such as the chordate Lepadogaster candolii, could have a negative impact due to competence with detritivores such as echinoderms. The objective of this work was to experimentally estimate the effects of mussel aquaculture on the abundance Lepadogaster candolii, compared with the abundance of the most abundant echinoderm Aslia lefevrei. Experimental units were built with a bag of 30 litre fill up with mussel shell, and they were deployed under aquaculture facilities (with sedimentation of organic matter) and control areas (without sedimentation of organic matter) in Galicia (Spain). As an additional control, sediment without experimental units was sampled using a square of $40 \times 40 \mathrm{~cm}$ and removing the substrate from the first $10 \mathrm{~cm}$. Experimental units were sampled after 5 months (July) and 8 months (September). The results showed a significant increase in the abundance of echinoderms in the raft zone, while in the control zone, chordates had the higher abundances. In terms of biomass, the values of Aslia lefevrei (Holothuroidea) was higher than those of the other taxa in the aquaculture zone and, in addition, an increase in time was observed in this zone. In contrast, the high values of Lepadogaster candolii (chordate) were shown in the control zone. In relation to the population structure, both in impacted and in control zones were a recruitment of the juveniles of $A$. lefevrei. In contrast, subadults and adults of $L$. candolii were more abundant. The accumulation of shells under mussel production systems, increasing the habitat complexity, seems to affect positively to both species $A$. lefevrei and L. candolii. However, with the increase of organic sedimentation the detritivores seem to be more competitive and the population abundance of L. candolii showed a drastic reduction. Echinoderms could play a key role in structuring benthic marine ecosystems affected by mussel aquaculture when a detrital food web dominated controlling other
\end{abstract}


populations, in spite the positive effect of habitat complexity increase due to shell accumulation.

Key words: Mussel; aquaculture; environmental management; macrofauna

\section{References:}

Abella, F. E., Parada, J. M. y Mora, J. (1996). Relationship between the macrobenthic community structure and the presence of mussel rafts culture in the Ria de Vigo (NW Iberian Peninsula). Crangon, 1, 111118.

Costelloe, J. (1988). Reproductive cycle, development and recruitment of two geographically separated populations of the dendrochirote holothurian Aslia lefevrei. Marine Biology, 99(4): 535-545.

Henriques, M., Lourenço, R. et al. (2002). A revision of the status of Lepadogaster lepadogaster (Teleostei: Gobiesocidae): sympatric subspecies or a long misunderstood blend of species?. Biological Journal of the Linnean Society, 76, 3: 327-338. doi: 10.1046/j.1095-8312.2002.00067.x. 


\title{
DIET COMPOSITIONS OF COMMERCIAL FISH SPECIES INHABITING SHALLOWER WATERS OFF THE COAST OF HUELVA (SW SPAIN) \\ Silvia Sierra Manchón', María Ángeles Torres ${ }^{2}$, José Ferrer Perea ${ }^{1}$, Oscar Moreno Escalante ${ }^{1}$
}

\author{
${ }^{1}$ Centro IFAPA Agua del Pino, Instituto Andaluz de Investigación y Formación Agroalimentaria y \\ Pesquera, 21459-El Rompido, Huelva, España. \\ Email:silvia.sierramanchon@gmail.com \\ ${ }^{2}$ Instituto Español de Oceanografía, Centro oceanográfico de Cádiz, Puerto Pesquero, Muelle de \\ Levante s/n Cádiz, España.
}

\begin{abstract}
Trophic relationships in the Gulf of Cadiz have been fully described for those species caught by trawling and purse seining fisheries (Torres, 2013). However, information of this kind of studies for species targeted by the artisanal fleet in shallower waters off the coast of Huelva remains scarce. As all fleets interact in the same area in a spatial-temporal frame (Jiménez, 2002), it is important to know if there are also differences in diet compositions of the target species by fleets in the light of implementing a more sustainable management of living resources and development of coastal areas. In this research, we analysed 650 stomach contents belonging to 12 fish species collected aboard artisanal commercial boats at dawn fishing around the coast of Huelva for a one-year period (2018). The following species analysed were selected based on their economic value and food dependence of the bottom: Dicologlossa cuneata, Diplodus bellottii, Halobatrachus didactylus, Pagellus erythrinus, Plectorhinchus mediterraneus, Pomadasys incisus, Raja asterias, Sepia officinalis, Solea senegalensis, Torpedo marmorata, Trachinus draco and Umbrina canariensis. The results showed that $43 \%$ of the stomachs analysed were empty, being $S$. senegalensis the species with a higher number of stomachs empty. The most frequent prey found were crustaceans (64\%), followed by small fishes $(14 \%)$, molluscs (10\%), annelids (7\%), echinoderms (4\%) and vegetal material $(1 \%)$. The diet of some of these species (U. canariensis, T. draco, P. mediterraneus, P. incisus, $R$. asterias) consisted mainly in crustaceans decapods like Upogebia $(6.13 \%)$ and in euphausiids (3.83\%). Other considered species (T. marmorata and S. officinalis) based their feeding mainly on fishes, while most abundant prey of the soleid D. cuneata are molluscs.
\end{abstract}

Key words: diet, stomach contents, small-scale fisheries, trophic relationships

Acknowledgments: This study was funded by FEMP, within the project "Propuestas para una gestion sostenible y planificación territorial de la pesca artisanal en el Golfo de Cádiz" (PLANART) 


\section{References:}

Jiménez, M.P. (2002). Aplicación de análisis multivariante para la obtención y estandarización de esfuerzos pesqueros en pesquerías multiespecíficas. Las pesquerías demersales del Golfo de Cádiz. Tesis doctoral. Universidad de Cádiz. 328 pp.

Torres, M.Á., Coll, M., Heymans, J.J., Christensen, V., Sobrino, I. (2013). Food-web structure of and fishing impacts on the Gulf of Cadiz ecosystem (South-western Spain). Ecological modelling 265,26-44. 


\title{
SPAWNING AND LARVAL DEVELOPMENT OF HOLOTHURIA FORSKALI, A NEW CANDIDATE FOR AQUACULTURE
}

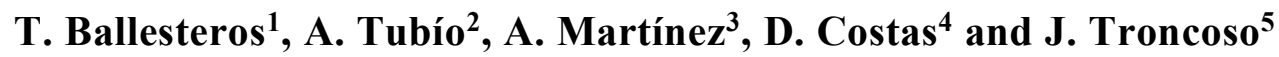 \\ 1,2,3,4,5 Estación de Ciencias Mariñas de Toralla (ECIMAT) (CIM-Uvigo), Vigo, SPAIN \\ tballesteros@uvigo.es,atubio@uvigo.es,arantxamc@uvigo.es,dcostas@ecimat.org, \\ troncoso@uvigo.es \\ 1,2,5 Departamento de Ecología y Biología Animal, Vigo, SPAIN
}

\begin{abstract}
Sea cucumbers are a very popular marine resource in Asia and the Mediterranean region, and the search for new, less valuable species in other areas is booming due to the overexploitation of traditional fishing grounds (Purcell, 2010; Purcell et al., 2013). Aquaculture could be a sustainable alternative to overcome these gaps and meet the current market demand. Holothuria (Panningothuria) forskali Delle Chiaje, 1823 is one of these new target species and the objective of our study was to describe its reproduction and larval development in captivity. Reproduction took place in the natural time of maturation of this species (Ballesteros et al., 2019). The first spawning was obtained spontaneously, without any treatment, after full moon in January, like Isostichopus badionotus (Zacarías-Soto et al., 2013) and Holothuria scabra (Morgan, 2000; Battanglene et al., 2002). The larval development of $H$. forskali is similar to other holothurians (Zacarías-Soto et al., 2013; Rakaj et al., 2018), with five stages: early, mid and late auricularia, doliolaria and pentactula. The early auricularia larvae appeared after 4 days whereas the last larval phase (pentactula) ocurred after 25 days. Larval development until the observation of the first juvenile lasted 27 days after fertilization. These results disagree with those obtained by Laguerre et al. (2020), who reported the first juveniles at 40 days. Although the cultivation of this species is still in its first steps, $H$. forskali potentially is a cultivable species that could help meet the demand gap, also helping to reduce the pressure on wild stocks and easing restocking actions.
\end{abstract}

Key words: Holothuria forskali, sea cucumber, aquaculture, spawning, larval development

Acknowledgments: To all the personnel of the Toralla Marine Science Station (ECIMAT) and to the fisher's guild of Cangas. This study was conducted under the project "Study of the biology, population status and genetic diversity of holoturia (Holothuria forskali) in the Ría de Vigo", financially supported by the Consellería do Mar, Xunta de Galicia. 


\section{References:}

Ballesteros, T., Tubío, A., Hernández, A., Rodríguez, R., Martínez, A., Gómez, R., Costas, D., Poza, E. \& Troncoso, J. (2019). Reproductive cycle of the sea cucumber Holothuria forskali in the Ría de Vigo: application to fisheries management. Frontiers in Marine Science. Abstract: XX Symposium on Marine Biology Studies (SIEBM XX). doi: 10.3389/conf.fmars.2019.08.00052

Battanglene, S. C., Seymour, J. E., Ramofafia, C. \& Lane, I. (2002). Spawning induction of three tropical sea cucumbers, Holothuria scabra, H. fuscogilva and Actinopyga mauritiana. Aquaculture, 207, 29-47.

Laguerre, H., Raymond, G., Plan, P., Améziane, N., Bailly, X. \& Le Chevalier, P. (2020). First description of embryonic and larval development, juvenile growth of the black sea-cucumber Holothuria forskali (Echinodermata: Holothuroidea), a new species for aquaculture in the North-Eastern Atlantic. Aquaqculture (in press).

Rakaj, A.; Fianchini, A., Boncagni, P. Lovatelli, A., Scardi, M. \& Cataudella, S. (2018). Spawning and rearing of Holothuria tubulosa: A new candidate for aquaculture in the Mediterranean region. Aquaculture Research, 49, 557-568.

Purcell, S. W., Mercier, A., Conand, C., Hamel, J. F., Toral-Granda, M. V., Lovatelli, A., Uthicke, S. (2013). Sea cucumber fisheries: Global analysis of stocks, management measures and drivers of overfishing. Fish and Fisheries, 14 (1), 34-59.

Purcell, S. W. (2010). Managing sea cucumber fisheries with an ecosystem approach (pp.157). A. Lovatelli, M. Vasconcellos and Y. Yimin (Ed.). Rome, Italy: FAO Fisheries and Aquaculture Technical Paper, No. 520.

Zacarías-Soto, M., Olvera-Novoa, M. A., Pensamiento-Villarauz, S. \& Sánxhez-Tapia, I. (2013). Spawning and Larval Development of the Four-Sided Sea Cucumber, Isostichopus badionotus (Selenka 1867), under Controlled Conditions. Journal of the world aquaculture society, 44 (5), 694-705. 

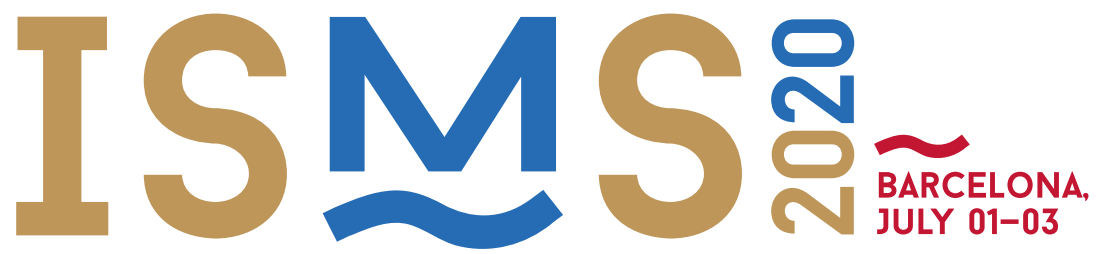

VII INTERNATIONAL SYMPOSIUM ON MARINE SCIENCES

\section{POSTER \\ COMMUNICATIONS}

\section{MANAGEMENT \\ OF THE MARINE ENVIRONMENT}




\title{
IMPACT OF TOURISM OVER TRADITIONAL FISHERIES IN IBIZA ISLAND
}

\author{
J. Pantoja' ${ }^{1}$ I. Montero' ${ }^{1}$, V. Mari ${ }^{2}$ F. Sobrado ${ }^{3}$ and A. Box ${ }^{2}$ \\ ${ }^{1}$ LEADER group, Ibiza, SPAIN. \\ jpantoja@conselldeivissa.es,imontero@conselldeivissa.es \\ ${ }^{2}$ Departament de Medi Ambient, Medi Rural i Marí, Consell d'Eivissa, Ibiza, SPAIN. \\ tonibox@conselldeivissa.es,vmari@conselldeivissa.es \\ ${ }^{3}$ GEN-GOB Eivissa, Ibiza, SPAIN. \\ Fransobrado33@hotmail.es
}

\begin{abstract}
During the last decades tourism has progressively increased on Ibiza Island. The increment of nautical traffic is directly connected to this growth. Every year thousands of boats visit the coasts of the Pitiüsas Islands (Ibiza and Formentera). This led to a conflict of interests with the local fishing sector and to the need of reconciling both activities. The fishery that is most affected by the interaction with recreational activities is the one using the so-called "minor gears". This fishery takes place in specific areas close to the shoreline, which have been used for this purpose since old times. They have to be preserved and taken into account in present and future land planning. The aim of our study was determinate the nature of the conflicts between such traditional fishery and the recreational use of the coast and adjacent waters. A location map of these artisanal fisheries and interactions was created from GPS data from both types of activities. Fishermen also helped identifying the main problems they recognized, ranging from $100 \%$ recognition for nautical traffic to $10 \%$ for organic waste. The outcome is a detailed map of all traditional fisheries using minor gears around the island of Ibiza. This map is now a tool ready to be used for the sustainable management of the coastal ecosystems of the island.
\end{abstract}

Key words: Nautical traffic, Traditional fisheries, Land planning, Interactions

Acknowledgments: The study has been made possible thanks to Consell d'Eivissa. The Local Action Group of Ibiza and Formentera are acknowledged for their assistance in data collection. We are also grateful to the fishermen's associations of Ibiza. 


\title{
EVOLUTION OF THE CATCH PER UNIT OF EFFORT (CPUE) OF THE SMALL-SCALE FISHERIES OF SPICARA SMARIS IN THE ISLAND OF IBIZA
}

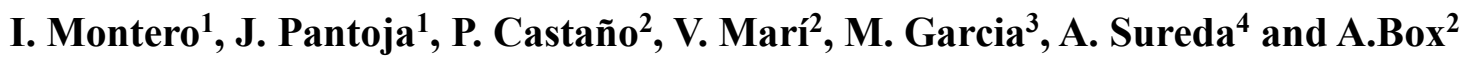 \\ ${ }^{1}$ LEADER group, Ibiza, SPAIN. \\ imontero@conselldeivissa.es,jpantojap@gmail.com \\ ${ }^{2}$ Departament de Medi Ambient, Medi Rural i Marí, Consell d'Eivissa, Ibiza, SPAIN. \\ pcastano@conselldeivissa.es,vmari@conselldeivissa.es,tonibox@conselldeivissa.es \\ ${ }^{3}$ Departamento de Biotectnología, Universidad de Alicante, Alicante, SPAIN. \\ m.garcia@ua.es \\ ${ }^{4}$ Research Group on Community Nutrition and Oxidative Stress (NUCOX), Department of \\ Fundamental Biology and Health Sciences and CIBEROBN, University of the Balearic Islands, \\ Palma de Mallorca, SPAIN. \\ Antoni.sureda@uib.es
}

\begin{abstract}
In October 2012, the Government of the Balearic Islands presented to the European Union a plea for an exception to Article 4.1 of Regulation (EC) n $n^{\circ} 1967 / 2006$, which establishes the Multi-island Management Plan for Fishing with Traditional stretch nets in the waters of the Balearic Islands. Our study monitors the catches of Spicara smaris and the effort made by the fleet to obtain these catches. With the data obtained, an index called Catches per Unit Effort (CPUE) is calculated, which allows the monitoring committee of the Balearic Government to evaluate the continuity of the fishing activity. The monitoring of CPUE is carried out monthly, from November to April, every year since 2013, when the plea was accepted.
\end{abstract}

The committee decides each month on the continuity or ban of fishing, based on the minimum limit for CPUE, used as an indicator of eventual excessive pressure on the stock. If the limit is not exceeded the committee applies the appropriate measures, which include a one day fishing ban per week during the first month. If the situation is maintained the same measure could be applied in consecutive months until the closure of the fishery. We conclude that the CPUE is a good parameter for the evaluation of the state of the S. smaris fishery, which so far is considered viable provided that it is actively controlled.

Key words: Catches per Unit Effort, Fishery monitoring, Spicara smaris, Ibiza Island

Acknowledgments: The local Action Group of Ibiza and Formentera (LEADER) funded this project. We also thank Consell d'Eivissa for making this study possible and the fishermen's associations of Ibiza Island for their assistance. 


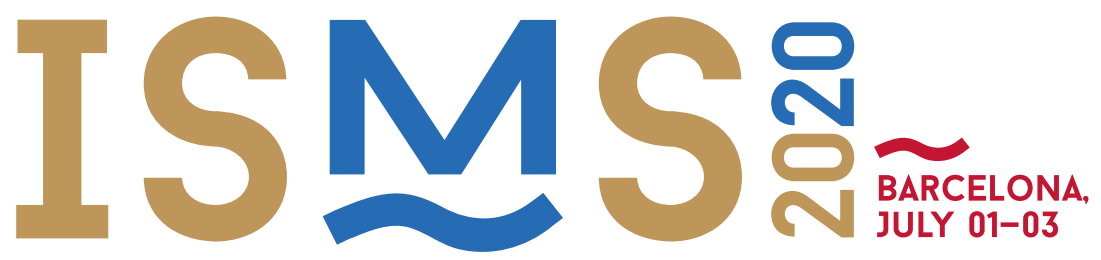

VII INTERNATIONAL SYMPOSIUM ON MARINE SCIENCES

\section{POSTER \\ COMMUNICATIONS}

\section{MARINE BIODIVERSITY}




\title{
CHARACTERIZATION OF TWELVE SPECIES OF THE MACRO-INFAUNA OF THE CADIZ COAST BEACHES (SOUTHWEST OF SPAIN)
}

\author{
A. García-González*1, C. Rodríguez-García ${ }^{1}$, R. Muñoz-Lechuga ${ }^{2}$, F. Hortas ${ }^{1,3}$ y R. \\ Cabrera-Castro ${ }^{1,3}$ \\ ${ }^{1}$ Departamento de Biología. Facultad de Ciencias del Mar y Ambientales. Universidad de Cádiz. \\ Cádiz, Spain. E-mail: alberto.garcigonza@alum.uca.es ; reme.cabrera@uca.es \\ ${ }^{2}$ Portuguese Institute for the Ocean and Atmosphere (IPMA), Avenida 5 de Outubro s/n, 8700- \\ 305, Olhão, Portugal. E-mail: ruben.lechuga@ipma.pt \\ ${ }^{3}$ Instituto Universitario de Investigación Marina (INMAR). Campus de Excelencia Internacional \\ del Mar (CEIMAR). Avda. República Saharaui, s/n, 11510 Puerto Real, Cádiz, Spain.
}

\begin{abstract}
Sandy beaches are ecosystems that connect marine and terrestrial systems, where macroinfauna play a very important role in the food web. In addition, these systems provide some advantages such as: sedimentation, decomposition of organic matter, storm dissipation, filtration and water purification (Ricciardi et al, 1999; Muñoz-Lechuga et al, 2018). Due to the relevance and interest that macroinvertebrates have in these areas, the aim of this work was to characterize the most relevant species of six beaches of the Cadiz coast (southwest of Spain): Santa María del Mar, Torregorda, Camposoto, Punta del Boquerón, La Barrosa and Caños de Meca. Twelve species were identified and obtained by means of a modified manual dredge (Muñoz-Lechuga et al, 2018). The most outstanding species were the shrimp Crangon crangon, the sea urchin, Echinocardium cordatum and crabs, Pachygrapsus marmoratus, Portumnus latipes and Liocarcinus depurator. In the samples, we also found the mysid Siriella armata, that is characterized as a model species in ecotoxicology studies (Pérez et al, 2010); the isopod Centraloecetes dellavallei that has an abundance that is inversely proportional to the amount of organic matter in the environment (Muñoz-Lechuga et al, 2018) and the isopod Lekanesphaera weilli which is considered as a good ecological indicator (Reyes-Martínez et al, 2015). In addition, new records have been obtained of the polychaetes Glycera tridactyla, Onuphis eremita and Sthenelais boa on the Atlantic Cadiz coast (Muñoz-Lechuga et al, 2018). Finally, a map of the distribution of the different species by beaches and a guide with files where the most important characteristics of each species collected was made.
\end{abstract}

Keywords: macroinfauna, sandy beaches, Cadiz coast, polychaetes, crustaceans.

Acknowledgments: Thanks to the RMN243_Fish Population Dynamics group for the samples provided from the Muñoz et al. work, 2018 for this study. 


\section{References:}

Pérez, S., and Beiras, R. (2010). The mysid Siriella armata as a model organism in marine ecotoxicology: comparative acute toxicity sensitivity with Daphnia magna. Ecotoxicology, 19(1), 196.

Muñoz-Lechuga, R., Gutiérrez-Martínez, M., Sanz-Fernández, V., Gómez-Cabeza, A. and Cabrera-Castro, R. (2018). Infralittoral-sublittoral (submerged zone) macroinfauna community structure of high-impact, medium-impact and non-impact beaches on the Gulf of Cádiz coast (SW Spain). Evaluation of anthropogenic alterations: Nourishments, human impact and urbanization. Marine Environmental Research, 133:85-98.

Reyes-Martínez, M. J., Ruiz-Delgado, M. C., Sánchez-Moyano, J. E., and García-García, F. J. (2015). Biodiversity and distribution of macroinfauna assemblages on sandy beaches along the Gulf of Cadiz (SW Spain). Scientia Marina, 79(3), 367-377.

Ricciardi, A., and Bourget, E. (1999). Global patterns of macroinvertebrate biomass in marine intertidal communities. Marine Ecology Progress Series, 185: 21-35. 


\title{
TRAVELING WITH LIVING CORALS: THE PACIFIC NUDIBRANCH BAEOLIDIA RIEAE CARMONA, POLA, GOSLINER \& CERVERA, 2014 ARRIVES TO BARCELONA AQUARIUMS IN SPAIN
}

\author{
A. Cabrito ${ }^{1, *}$, C. Galià-Camps ${ }^{1,2}$ and M. Ballesteros ${ }^{1}$ \\ (1) Departament de Biologia Evolutiva, Ecologia i Ciències Ambientals, Universitat de \\ Barcelona, 08028, Barcelona, SPAIN. \\ (2)andrea.cabritorubau@gmail.com,carlesgalia@ub.edu,mballesteros@ub.edu \\ (3) Departament de Genètica, Microbiologia i Estadística, Institut de Recerca de la Biodiversitat \\ (IRBio), Universitat de Barcelona, 08028, Barcelona, SPAIN.
}

\begin{abstract}
The aeolid nudibranch Baeolidia rieae Carmona, Pola, Gosliner \& Cervera, 2014 was described with only one specimen collected on the subtropical Amami-Oshima Island (SW Japan) (Carmona et al., 2014). In this study we record the presence of about twenty individuals of $B$. rieae that appeared feeding on the commercial Indopacific coral Zoanthus sp. into an aquarium shop in Barcelona (Spain). The morphological and molecular features of the individuals match with the original description of $B$. rieae and corroborate its identification. We discuss the resistance of this species to the disinfection process that rocks and living materials imported from the Pacific are subjected to, the damage that $B$. rieae could cause in coral species of commercial interest on tropical salt water aquariums, and how this species may become an invasive species would it be common in other aquarium shops around the world. We also provide new morphology data of B. rieae, its symbiotic relationship with zooxanthellae algae (Rudman, 1981) and a first description of the spawn and eggs of this species.
\end{abstract}

Key words: commercial aquariums, Zoanthus, nudibranchs, invasive species

Acknowledgments: We thank the manager of the Urban Natura tropical aquarium shop in Barcelona and the shop assistant Manel Enrubia for collecting the specimens that appeared in their aquariums. This work has benefited from research funds granted by the Catalan Government to the consolidate research group in Biology and Ecology of Benthos (BEB) (SGR2017-1120) of the University de Barcelona.

\section{References:}

Carmona, L., Pola, M., Gosliner, T.M. and Cervera, J.L. (2014). Review of Baeolidia, the largest genus of Aeolidiidae (Mollusca: Nudibranchia), with the description of five new species. Zootaxa, 3802 (4): 477-514. 
Rudman, W.B. (1981). The taxonomy and biology of further aeolidacean and arminacean nudibranch molluscs with symbiotic zooxanthellae. Zoological Journal of the Linnean Society, 74: 147-196. 


\title{
TWO OCEANS: BIOGEOGRAPHIC AND TAXONOMIC REVIEW OF MARINE HETEROBRANCH SEASLUGS (MOLLUSCA: GASTROPODA) FROM PANAMA WATERS (PRELIMINARY STUDY).
}

\author{
Darío Córdoba $^{1 *}$, Ángel Valdés ${ }^{2}$ \& Manuel Ballesteros ${ }^{3}$ \\ 1,3 Departament de Biologia Evolutiva, Ecologia y Ciències Ambientals, Facultat de Biologia, \\ Universitat de Barcelona, avda. diagonal, 643, 08028, Barcelona, Spain, mballesteros@ub.edu \\ *dcg213@cwpanama.net and Orcid:0000-0002-0693-4176 \\ 2 Department of Biological Sciences, California State Polytechnic University, 3801 west \\ temple avenue, Pomona, California, United State, 91768-4032, aavaldes@cpp.edu
}

\begin{abstract}
From the collections of marine slugs in coastal waters of Panama made by C.B. Adams (1852), Zetek (1918), Strong \& Hertlein (1939), Vega \& González (2002), Collin et al. (2005), Avilés (2010) and Goodheart et al. (2016); there has been no exhaustive taxonomic description of all species of "opistobranchs" (Mollusca: Gastropoda: Heterobranchia) on the Panamanian coast. In this work, bibliographic references and confirmed photographs of the species found in Panamanian coastal waters were collected. Furthermore, to confirm their presence, a collection of live specimens was made in different Panamanian coastal areas. To complete the information, each described species has its diagnosis and comments, including if they belong to the Pacific Ocean, to the Caribbean Sea, are present on both coasts or are amphiatlantic. The resulting annotated catalogue contains 246 species of opistobranchs, of which 108 live on the Caribbean coast, 130 on the Pacific coast, 5 on both Panamanian coasts. Eighteen have an amphiatlantic distribution, while 29 have not yet been described up to the species category.
\end{abstract}

Key words: Opistobranchs, Heterobranchia, Panamanian coasts, Caribbean, Pacific

Acknowledgments: I thank the IFARHU-SENACYT scholarship program and the Department of Evolutionary Biology, Ecology and Environmental Sciences of the Faculty of Biology of the University of Barcelona.

\section{References:}

Adams, C.B. (1852). Catalogue of shells collected of Panama with notes on their synonymy, station and geographical distribution. R. Craighead printer, New York, United State, Annals of Lyceum of Natural History of New York, volume V, 303 pp.

Avilés, M.C. (2010). Listado preliminar de moluscos opistobranquios de la República de Panamá. MUMAUP, 3: 1-23.

Collin, R.; Díaz, M.C.; Norenburg, J.; Rocha, R.M.; Sánchez, J.A. \& Schulze, A. (2005). Photographic identification guide to some common marine invertebrates of Bocas Del Toro, Panama. Caribbean Journal of Science, 41:638-707. 
Goodheart, J.; Ellingson, R.; Vital, X.; Galvão, H.; McCarthy, J.; Medrano, S.; Bhave, V.; García-Méndez, K; Jiménez, L.; López, G.; Hoover, C.; Awbrey, J.; De Jesus, J.; Gowacki, W.; Krug, P. \& Valdés, A. (2016). Identification guide to the heterobranch sea slugs (Mollusca: Gastropoda) from Bocas del Toro, Panama. Marine Biodiversity Records, 9:1-31.

Strong, A.M. \& Hertlein, L.G. (1939). Marine mollusks from Panama collected by the Allan Hancock Expedition to the Galapagos Islands, 1931-1932. Allan Hancock Pacific Expeditions, 2: 177-246.

Vega, A. \& González, A. (2002). Moluscos del pacífico veragüense, parte II (Gasteropoda). Tecnociencia, 4(1): 23-45.

Zetek, J. (1918). Los moluscos de la República de Panamá, REVISTA NUEVA, Números 1 y 2: 1-37. 


\title{
ISMS
}

VII International Symposium on Marine Sciences

ISMS 2020

Barcelona (Spain), $1^{\text {st }}-3^{\text {rd }}$ July 2020

\section{ESTIMATING THE TROPHIC POSITION OF THE AQUATIC CONSUMER Dugastella valentina USING STABLE ISOTOPES}

\author{
M. J. Sánchez-Guerrero Hnz. ${ }^{1}$, A. Martínez Lage² and E. González-Ortegón $^{3}$ \\ ${ }^{1}$ Universidad de Cádiz, Puerto Real, SPAIN \\ miky.sangh@gmail.com \\ ${ }^{2}$ Universidade da Coruña, Departamento de Biología, A coruña, SPAIN \\ andres.martinez@udc.es \\ ${ }^{3}$ Instituto de Ciencias Marinas de Andalucía (CSIC), Cádiz, SPAIN \\ quique.gonzalez@icman.csic.es
}

\begin{abstract}
The ecological role of consumers in a food web requires identifying their energy sources to estimate their trophic positions (TPs). This is relevant in ecosystems inhabited by endemic species such as the decapod crustacean Dugastella valentina. This species inhabits the freshwater streams around the Gulf of Valencia (eastern Spain) which has been categorized as "Near Threatened" by the IUCN. The stable isotopes of $\mathrm{N}\left({ }^{15} \mathrm{~N} /{ }^{14} \mathrm{~N}, \delta^{15} \mathrm{~N}\right)$ and $\mathrm{C}\left({ }^{13} \mathrm{C} /{ }^{12} \mathrm{C}, \delta{ }^{13} \mathrm{C}\right)$ have been proposed as a powerful technique for estimating the TP of consumers using one or multiple baselines (BL). In this study, the TP of D. valentina was estimated from primary producers (plants and algae), organic matter (leaf litter and detritus), and different functional groups of invertebrates (scrapers, filter feeders and collectors) of the upper stretch of the Algar River (eastern Spain). We model consumer and BL observations using the R package, "tRophicPosition" (Quezada-Romegialli et al., 2018). Among potential BL indicators, we selected the organisms showing the lowest values of $\delta^{15} \mathrm{~N}$. That is, oligochetes which feed on organic matter (representing the benthic BL) and bivalve mollusks, as filter feeders on phytoplankton (representing the pelagic BL). The estimated TP for this decapod in this study is consistent with previous work carried out in other streams, with intermediate values observed between primary consumers (e.g. filter feeders) and secondary (e.g. predatory invertebrates). In this way, the fact that this predatory invertebrates ingest algae and detritus could explain values TP $<3$. Nevertheless, a further sampling effort is needed to select a BL indicator for the upper stretches of these rivers, which have been poorly studied from a trophic point of view.
\end{abstract}

Key words: $\delta^{13} \mathrm{C}, \delta^{15} \mathrm{~N}$, Stable isotope analysis, Baselines, Trophic position, Stream.

Acknowledgments: Financial support to EGO was given by CSIC through Intramural Research program 2018 under grant number 201830I081.

\section{References:}

Quezada-Romegialli, C., Jackson, A. L., Hayden, B., Kahilainen, K. K., Lopes, C., \& Harrod, C. (2018). tRophicPosition, an R package for the Bayesian estimation of trophic position from consumer stable isotope ratios. Methods in Ecology and Evolution, 9(6), 1592-1599. 


\title{
ON THE DISTRIBUTION OF A FREQUENT ACTINIARIA OF THE CANARY ISLANDS, TELMATACTIS CRICOIDES (CNIDARIA, ANTHOZOA, ACTINIARIA), AND ITS ASSOCIATED FAUNA.
}

\author{
Peraza, E., \& Clemente, S. \\ Grupo de investigación en Biodiversidad, Ecología Marina y Conservación (BIOECOMAC) \\ Departamento de Biología Animal, Edafología y Geología, Universidad de La Laguna. Spain. \\ eulaliapg4a1011@gmail.com,msclemen@ull.edu.es
}

\begin{abstract}
This study shows new data on the populations of the actiniarian Telmatactis cricoides, abundant on intertidal and shallow sublittoral environments of the Canary Islands. We assessed the symbiotic relationships that they establish with other species, as well as some morphological characteristics and their distribution. Organisms were sampled by SCUBA diving, using an underwater camera to record color patterns and a scale to obtain sizes of the anemones. This research was carried out at four locations on the eastern coast of Tenerife, in a depth range of 5-35 m. A total of 145 individuals of $T$. cricoides were recorded. The largest anemones were found at 15-30 m depth, with a maximum size of $22 \mathrm{~cm}$ of oral disk. Twenty-one different color patterns were recorded for the species, which seemed to be related to the sizes of the individuals. $65,5 \%$ of the anemones established symbiotic relationships with other organisms. A total of ten different species were found in symbiosis with $T$. cricoides, all of them crustaceans, being the decapods Thor amboinensis and Stenorhynchus lanceoaltus the most frequent ones. The abundance and composition of the symbiotic community was related to the size of the host, recording up to 13 different individuals in association with a single anemone. These results represent an advance in the knowledge of some poorly known characteristics of this species and their populations, especially relevant to begin to understand some symbiotic relations between common organisms in benthic environments of the Canary Islands.
\end{abstract}

Key words: anemones, color patterns, size frequency, symbionts 


\title{
GLOBAL PATTERNS AND DRIVERS OF MARINE SESSILE BIODIVERSITY: UNRAVELING THE SOUTHERN OCEAN AS AN IMPORTANT HOTSPOT OF BIODIVERSITY AND CLIMATIC REFUGE-
}

\author{
Marta Pagès-Escolà ${ }^{1}$, Cristina Linares ${ }^{1}$, Ignasi Montero-Serra ${ }^{2}$, Bernat Hereu ${ }^{1}$, Mark \\ John Costello ${ }^{3}$ \\ ${ }^{1}$ Department of Evolutionary Biology, Ecology and Environmental Sciences, Institut de Recerca \\ de la Biodiversitat (IRBIO), University of Barcelona, Av. Diagonal 643, 08028 Barcelona, Spain \\ mpagesescola@gmail.com,cristinalinares@ub.edu,hereu@ub.edu \\ ${ }^{2}$ Marine Spatial Ecology Lab, School of Biological Sciences, University of Queensland, Australia. \\ monteroserra@gmail.com \\ ${ }^{3}$ Institute of Marine Sciences, 23 Symonds St, Auckland 1142, New Zealand. \\ m.costello@auckland.ac.nz
}

\begin{abstract}
One of the goals of ecology is to understand biodiversity patterns at global spatial scales and their main drivers. The recent increase in data availability and computational power has led to major advances in macroecology providing unprecedented opportunities to test biogeographic hypothesis using field observations. Accordingly, the most accepted diversity pattern is the increase in species richness from high latitudes towards the tropics. However, recent studies suggested that the highly heterogeneous sampling effort can result in biased conclusions about diversity patterns highlighting the need to account for its differences in biogeographical studies. Here, we analyzed global diversity patterns and sampling effort of marine sessile groups, accounting for their environmental drivers. Most of latitudinal patterns of marine sessile groups showed a dip in the number of species at the equator, and an increase of diversity at the Southern Ocean, and particularly, at the Antarctic shelf. Conversely, potential biases in the sampling effort of marine sessile species showed that regions have not been equally sampled, with higher efforts on North Temperate Atlantic areas. Environmental models showed that depth, nitrate, and SST are the best drivers for marine sessile diversity, and highlight the importance of considering differences on sampling effort in marine systems. Finally, we project warming trends in marine systems at the final of this century and we predicted that the northern hotspot areas will be the most impacted areas. Contrary, Southern Ocean will be the least impacted area by ocean warming, suggesting that the high diversity of sessile species is related to the fact that this area has suffered lower thermal stress over evolutionary time than other areas and may represent a climate refuge under the increasing warming scenario.
\end{abstract}

Keywords: macroecology, biogeography, diversity patterns, sampling effort, marine sessile species, Southern Ocean. 


\section{References:}

Chaudhary, C., Saeedi, H., and Costello, M. J. (2016). Bimodality of latitudinal gradients in marine species richness. Trends in ecology and evolution, 31(9), 670-676.

Chaudhary, C., Saeedi, H., and Costello, M. J. (2017). Marine species richness is bimodal with latitude: A reply to Fernandez and Marques. Trends in ecology and evolution, 32(4), 234-237.

Costello, M. J., Tsai, P., Wong, P. S., Cheung, A. K. L., Basher, Z., and Chaudhary, C. (2017). Marine biogeographic realms and species endemicity. Nature communications, 8(1), 1057.

Tittensor, D. P., Mora, C., Jetz, W., Lotze, H. K., Ricard, D., Berghe, E. V., and Worm, B. (2010). Global patterns and predictors of marine biodiversity across taxa. Nature, 466(7310), 1098. 


\title{
IDENTIFYING THE ORIGIN OF NEW COLONIZATIONS IN SEA TURTLES
}

\author{
Alba Covarrubias', Carlos Carreras ${ }^{2}$, Elena Abella ${ }^{3}$ and Marta Pascual ${ }^{4}$ \\ ${ }^{1,2,4}$ Departament de Genètica, Microbiologia i Estadística - IRBio, Universitat de Barcelona, \\ Avinguda Diagonal 643, 08028 Barcelona, Spain. \\ albacova96@gmail.com,carreras@ub.edu,mpascual@ub.edu \\ ${ }^{1,3}$ Universitat de Vic, Carrer de la Sagrada Família 7, 08500 Vic, Spain. \\ elena.abella@uvic.cat
}

\begin{abstract}
The sporadic nesting events of the loggerhead turtle (Caretta caretta) in the western Mediterranean have increased in this century. These nesting events could be the start point of new stable populations and thus we could be observing the initial steps of the colonizing process of long-lived species. This increase could be in response to climate change and become vital for the survival of the species. The success of a colonization phenomenon like the one that is happening on our beaches depends on three key elements: a) a correct management of these nesting events, b) a scientific study of this unique phenomenon in the world and c) the dissemination to the public for an early alert of these events. With these objectives in mind, we have started NIDOS-Caretta a project that brings together genomic techniques, environmental data and outreach activities with the aim to improve the management of these nesting events with scientific based information. One of the main tasks is to determine the origin of the breeders, explore the degree of multipaternity and relate this information with fitness parameters such as the number of eggs laid and the viability of hatchlings considering genomic and environmental information. As a proof of concept, we extracted DNA of hatchlings of the nest of Premià (Barcelona) from 2018, built 2b-RAD libraries after digestion with AlfI restriction enzyme and ligation with selective base adapters (Barbanti et al. 2020), and single-end sequenced in a HiSeq platform. The results obtained will be discussed.
\end{abstract}

Key words: loggerhead turtle, sporadic nesting, global warming

Acknowledgments: This work is supported by project NIDOS-Caretta funded by Fundación Biodiversidad, del Ministerio para la Transición Ecológica y el Reto Demográfico.

References: please follow the examples below

Barbanti, A., Torrado, H., Macpherson, E., Bargelloni, L., Franch, R., Carreras, C., and Pascual, M. (2020). Helping decision making for reliable and cost-effective $2 b-R A D$ sequencing and genotyping analyses in non-model species. Molecular Ecology Resources. doi: 10.1111/1755-0998.13144. 


\title{
Population structure of the stone crab Xantho poressa (Olivi, 1972) in a human restricted access area
}

\section{Nebis Navarro Ojeda ${ }^{123}$, Jose A. Cuesta ${ }^{1}$ and Enrique González-Ortegón ${ }^{1}$}

\author{
${ }^{1}$ Instituto de Ciencias Marinas de Andalucía (ICMAN-CSIC), Puerto Real, SPAIN \\ ${ }^{2}$ Campus de Excelencia Internacional del Mar (CEIMAR) \\ ${ }^{3}$ Facultad de Ciencias Básicas y Biomédicas, Universidad Simón Bolívar, Barranquilla, \\ COLOMBIA \\ nebisadriana.navarroojeda@alum.uca.es,jose.cuesta@icman.csic.es,quique.gonzalez@icman.csic.es
}

\begin{abstract}
:
The stone crab Xantho poressa, is an intertidal species that inhabits the Gulf of Cadiz (GoC), the Mediterranean Sea, the Black Sea and the Canary Islands. In the GoC, this crab inhabits hiding under boulders of rocky beaches, but little information exists regarding its population. The main objective of this research was to analyse the population structure of $X$. poressa in an intertidal rocky shore beach with restricted access (Torregorda beach, SW Spain). A total of 190 boulders were analysed monthly from March 2019 and February 2020. In the field, individuals of $X$. poressa were sexed and crab size was measured using the carapace width $(\mathrm{CW})$. Accompanying fauna and boulder information (location, size, and weight) were also collected. A total of 1386 individuals were analysed during the studied year (667 females, 411 males, 269 juveniles and 39 undefined individuals). The overall sex ratio differed from the 1:1 assumption on each month (except in December 2019), and seasonally. The size of adult males and females showed significant difference $(\mathrm{p}<0.05)$ and varied from 11.54 to $38.19 \mathrm{~mm} \mathrm{CW}(20.17 \pm 5.08 \mathrm{~mm})$, and 10.12 to 28.08 $\mathrm{mm} \mathrm{CW}(16.22 \pm 3.39 \mathrm{~mm})$ respectively. The modal class for females was $14-16 \mathrm{~mm}$ $\mathrm{CW}$ and $20-22 \mathrm{~mm} \mathrm{CW}$ for males. Multivariate analysis showed that X. poressa distribution in the intertidal shore seems to be mainly determined by the weight of the boulder. The frequent coexistence of a male and various females under a boulder should explain the female-biased sex ratio observed in this study which was previously suggested in another beach of the GoC.
\end{abstract}

Key words: Xantho poressa, Torregorda, sex ratio, Corrales de Rota.

Acknowledgments: We thank the Spanish Ministry of Defence, INTA, A. Moreno, D. Roque, Universidad Simón Bolívar and the AUIP for their support in this research. 


\title{
LIFE STRATEGIES AND HABITAT PREFERENCES OF TWO ESPECIALIZED FISH SPECIES IN THE NW MEDITERRANEAN DEEP SEA
}

\author{
Sara Dallarés*1, Joan E. Cartes ${ }^{2}$ and Maite Carrassón ${ }^{3}$ \\ ${ }^{1,3}$ Departament de Biologia Animal, Biologia Vegetal i Ecologia, Universitat Autònoma de \\ Barcelona, Bellaterra (Cerdanyola del Vallès), SPAIN. \\ sara.dallares@uab.cat,maite.carrasson@uab.cat \\ ${ }^{2}$ Departament de Recursos Marins Renovables, Institut de Ciències del Mar (ICM - CSIC), \\ Barcelona, SPAIN. \\ jcartes@icm.csic.es
}

\begin{abstract}
Cataetyx alleni and Melanostigma atlanticum are two poorly known small-sized fishes showing peculiar features regarding their reproductive biology and behaviour (Silverberg et al., 1987; Follesa et al., 2011). Present research reveals different aspects regarding the biology and ecology of these species in the slopes of the Balearic basin. Specimens were collected during the last 30 years during different oceanographic cruises. Geographical/habitat distribution, population structure, diet, parasite infections and trends on biological indices were addressed. Higher population density of C. alleni was found in the mainland than in the insular slope of the Balearic basin and in the middle ( $\mathrm{ca} .800$ $1400 \mathrm{~m}$ depth) than in upper and lower slopes (ca. 200-800 and below $1400 \mathrm{~m}$ depth, respectively). $M$. atlanticum was only sampled in the mainland slope, mostly from upper and middle slopes and preferably south to submarine canyons, probably linked to sediment depocenters. For $C$. alleni, a bigger-deeper trend occurred for both sexes from spring to autumn. For $M$. atlanticum, this same pattern was observed for females and no seasonal trends were appreciated. Regarding diet, $C$. alleni intestinal fullness was highest in the upper slope in spring and in the middle slope in summer, and main diet items recovered comprised polynoid polychaetes, calanoid copepods, amphipods, isopods, mysids and decapods. M. atlanticum stomach fullness trends could only be observed in the upper slope, where it was higher in summer than in autumn, and main diet items recovered were calanoid copepods and polychaetes. Parasite assemblages of both species displayed low richness, diversity and abundance, and were largely composed by larval parasites, indicating a low-intermediate position within local food webs. For C. alleni, gonadosomatic index peaked in autumn, coinciding with the reproductive season of this species, and condition factor increased in spring-summer and decreased with depth. Hepatosomatic index increased in summer for both species.
\end{abstract}

Key words: Balearic Sea, deep-sea, Cataetyx alleni, Melanostigma atlanticum (3 to 5 key words)

Acknowledgments: This study was supported by the CSIC and CAICYT project BATIMAR and by the MICYT projects BIOMARE, ANTROMARE and RECOMARES. 


\section{References:}

Silverberg, N., Edenborn, H.M., Ouellet, G. and Béland, P. (1987). Direct evidence of a mesopelagic fish, Melanostigma atlanticum (Zoarcidae) spawning within bottom sediments. Environmental Biology of Fishes, 20 (3), 195-202.

Follesa, M.C., Porcu, C., Mulas, A., Salvadori, S. and Cau, A., (2011). Reproductive characteristics of the bathyal viviparous fish Cataetyx alleni (Osteichthyes: Bythitidae) from the southeastern Sardinian Sea (central-western Mediterranean). Scientia Marina, 75 (2), 391-397. 


\title{
FAUNA OF THE SYLLIDAE (ANNELIDA: POLYCHAETA) FROM SOCOTRA ARCHIPELAGO (INDIAN OCEAN)
}

\author{
Yolanda Lucas Rodríguez ${ }^{1,2}$ Guillermo San Martín ${ }^{1,2}$ \& Dieter Fiege ${ }^{3}$ \\ 1 Centro de Investigación en Biodiversidad y Cambio Global (CIBC-UAM). Universidad \\ Autónoma de Madrid, SPAIN. \\ yolanda.lucas@uam.es, guillermo.sanmartin@uam.es \\ 2 Universidad Autónoma de Madrid, Departamento de Biología (Zoología), Facultad de \\ Ciencias, Madrid, SPAIN. \\ 3 Senckenberg Forschungsinstitut und Naturmuseum Frankfurt, Senckenberganlage 25, D- \\ 60325Frankfurt/Main, GERMANY. \\ dieter.fiege@senckenberg.de
}

\begin{abstract}
:
Marine annelids were surveyed in the scope of the project "Conservation and Sustainable Use of Biodiversity of Socotra Archipelago" funded by the Global Environment Facility (GEF). About 650 specimens of polychaetes belonging to 19 families were collected at more than twenty locations. The Syllidae, one of the most speciose families of polychaetes with more than 700 species occurring in a wide variety of habitats was studied by Lucas et al. (2017, 2019, 2020).

24 species of Syllidae were recorded from Socotra Archipelago They belong to the following genera in four subfamilies: Syllinae: Branchiosyllis, Haplosyllis, Megasyllis, Opisthosyllis, Syllis, Trypanosyllis; Eusyllinae: Eusyllis, Odontosyllis; Exogoninae: Salvatoria, and Autolytinae: Myrianida.

Four species were described as new to science: Branchiosyllis inesae Lucas et al. 2017, Branchiosyllis camblori Lucas et al. 2017, Trypanosyllis mercedesae Lucas et al. 2019 and Syllis qamhiyn Lucas et al. 2020.

The following species were cited, redescribed or original description supplemented.
\end{abstract}

Key words: Syllidae, Socotra Archipelago, taxonomy, new species.

Acknowledgments: This study was conducted with partial financial support from the Global Environment Facility (GEF) supporting the project "Conservation and Sustainable Use of Biodiversity of Socotra Archipelago", overseen by the United Nations Office for Project Services (UNOPS YEM/96/G32) in conjunction with the Environmental Protection Council (EPC) of Yemen. 


\section{References:}

Lucas, Y., San Martín, G. \& Fiege, D (2017) Two new species of Branchiosyllis Ehlers, 1887 (Annelida: Polychaeta: Syllidae) and redescription of Branchiosyllis exilis (Gravier, 1900), from Socotra Archipelago (Yemen, Indian Ocean). Marine Biodiversity, 48 (3), 1519-1527.

https://doi.org/10.1007/s12526-017-0657-8

Lucas, Y; San Martín, G; Fiege, D.(2019). A new species and nine new records of Syllidae (Annelida) from the Socotra Archipelago (Indian Ocean). Zootaxa. 4651(2): 235-258.

Lucas, Y; San Martín, G; Fiege, D.(2020). New species and records of the genus Syllis Savigny in Lamarck, 1818 (Annelida: Syllidae) from Socotra Archipelago (Indian Ocean). In press. 


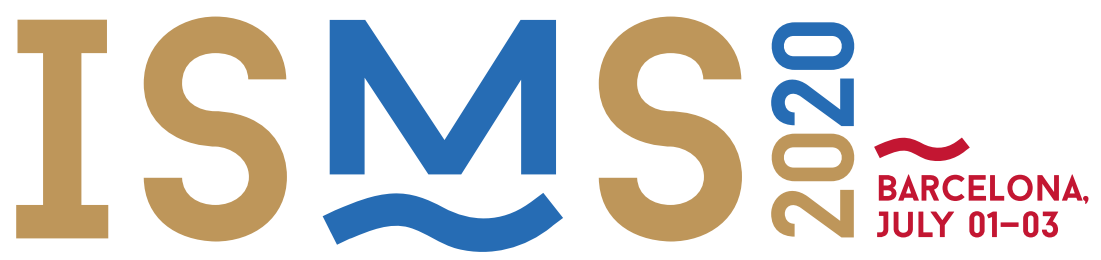

VII INTERNATIONAL SYMPOSIUM ON MARINE SCIENCES

\section{POSTER \\ COMMUNICATIONS}

\section{MARINE ECOSYSTEMS}




\title{
RAPID ASSESSMENT SURVEY OF BIOFOULING IN TWO MARINAS OF ALICANTE (SW MEDITERRANEAN)
}

\author{
A. Carmona Rodríguez ${ }^{* 1}$, J. Úbeda Quesada ${ }^{1}$, B. Ibañez Rugero ${ }^{1}$ and A.A. Ramos \\ Esplá $^{2}$ \\ ${ }^{1}$ Departamento de Ciencias del Mar y Biología Aplicada, Universidad de Alicante, Alicante, \\ SPAIN. \\ acr648@gmail.com,julioubedaquesada@gmail.com,barbaraiva8@gmail.com \\ ${ }^{2}$ Centro de Investigación Marina de Santa Pola (CIMAR), Universidad de Alicante, 03080 \\ Alicante, SPAIN. \\ alfonso.ramos@ua.es
}

\begin{abstract}
Shipping is considered the major pathway for non-indigenous species (NIS). The Mediterranean Sea hosts over $70 \%$ of global recreational boat traffic (Ferrario et al., 2017; Ulman et al., 2017). Not only does shipping increase the arrival of NIS, but also the artificial structures which are found in ports and marinas (Ferrario et al., 2017). Thus, ports and marinas are a major hotspot of invasions (Albano and Obenat, 2019). The aim of this study was to characterize the biofouling community inhabiting marinas and its seasonal variation in the SW Mediterranean (Alicante, Spain). In order to achieve this goal, two marinas (Guardamar and Campello) were sampled by using a Rapid Assessment Survey (RAS) approach (Pederson et al., 2005) in 2018 during summer (August) and winter (March). Over 30 taxa of sessile invertebrate where recorded in artificial submerged structures, such as floating pontoons, hanging ropes, buoys and defences. The biofouling assemblages show clear differences among seasons, with Serpulidae (Polychaeta) and bryozoans becoming dominant in both seasons. Other groups like ascidians and Balanidae were more abundant during winter. The Guardamar marina, near the mouth of the Segura River, showed differences with Campello, recording less diversity and the dominance of few species. Furthermore, the presence of NIS in the marinas was evident with species such as Celleporaria brunnea, Watersipora arcuata, Bugula neritina and Amphibalanus amphitrite.
\end{abstract}

Key words: Fauna, Rapid Assessment Survey, SE Iberian Peninsula, Mediterranean Sea

Acknowledgments: We thank the personnel from the investigated marinas for granting permission for this study.

\section{References:}

Albano, M.J., and Obenat, S.M. (2019). Fouling assemblages of native, non-indigenous and cryptogenic species on artificial structures, depths and temporal variation. Journal of Sea Research, 144, 1-15. 
Ferrario, J., Caronni, S., Occhipinti-Ambrogi, A., and Marchini, A. (2017). Role of commercial harbours and recreational marinas in the spread of non-indigenous fouling species. Biofouling 33 (8), 651-660.

Ulman, A., Ferrario, J., Occhpinti-Ambrogi, A., Arvanitidis, C., Bandi A, Bertolino, M., Bogi, C., Chatzigeorgiou, G., Çiçek, B. A., Deidun, A., Ramos-Esplá, A., Koçak, C., Lorenti, M., Martinez-Laiz, G., Merlo, G., Princisgh, E., Scribano, G. and Marchini, A. (2017). A massive update of nonindigenous species records in Mediterranean marinas. PeerJ, e3954.

Pederson, J., Bullock, R., Carlton, J.T., Dijkstra, J., Dobroski, N., Dyrynda, P., Fisher, R., Harris, L., Hobbs, N., Lambert, G., Lazo-Wasem, E., Mathieson, A., Miglietta, M.P., Smith, J., Smith, J.III, and Tyrrell, M. (2005). Marine Invaders in the Northeast: Rapid Assessment Survey of non-native and native marine species of floating dock communities (August 2003). Publication No. 05-03, Cambridge, Massachusetts Institute of Technology, Sea Grant College Program. 40 p. 


\title{
DISENTANGLING FOOD WEBS IN Cymodocea nodosa: COMPARING MAIN PREYS FOR Xyrichtys novacula USING STABLE ISOTOPE DATA
}

\author{
A. Cohen-Sánchez ${ }^{1 *}$, A. Blanco ${ }^{2,3}$, A. Sureda $^{4}$, I. Montero ${ }^{5}$, S. Tejada ${ }^{6}$, A. Box ${ }^{7}$ \\ ${ }^{1}$ University of Balearic Islands, Palma de Mallorca, SPAIN. \\ amanda.cohen1@estudiant.uib.cat \\ ${ }^{2}$ School of Biology, Faculty of Biological Sciences, University of Leeds, Leeds, \\ UNITED KINGDOM. \\ ${ }^{3}$ Departamento de Ecoloxía e Bioloxía Animal, Universidade de Vigo, Campus As \\ Lagoas-Marcosende, Vigo, SPAIN. \\ andreu.blanco@gmail.com \\ ${ }^{4}$ Research Group on Community Nutrition and Oxidative Stress, University of Balearic Islands, \\ Palma de Mallorca, SPAIN; and CIBERON, University of the Balearic Islands, Palma de Mallorca, \\ SPAIN. \\ antoni.sureda@uib.es \\ ${ }^{5}$ Technician group LEADER, Ibiza, SPAIN. \\ imontero@conselldeivissa.es \\ ${ }^{6}$ Laboratory of Neurophysiology, Departament of Biology and CIBERON, University of the \\ Balearic Islands, Palma de Mallorca, SPAIN. \\ silvia.tejada@uib.es \\ ${ }^{7}$ Department of Agricultura, Ramaderia, Caça, Pesca i Cooperació Municipal, Consell Insular \\ d'Eivissa, Ibiza, SPAIN. \\ tonibox@conselldeivissa.es
}

\begin{abstract}
Seagrass meadows are one of the most important coastal ecosystems in the Mediterranean Sea. The present study compares the food webs in Cymodocea nodosa sandy bottoms in a Marine Protected Area (MPA) versus a non-protected area and establishes the importance of the main food items for the recreational target specie Xyricthys novacula. These habitats lack primary producers and, specifically, in the studied area only the seagrass C. nodosa and its epiphytic macroalgae are present. In both areas, organic matter, primary producers and different taxa of Polychaeta, Mollusca, Crustacea, Echinodermata and Chordata (13-14 species) were sampled. The results show clear differences in food webs, with a higher invertebrate abundance in the non-protected area and in $\delta^{13} \mathrm{C}$ and $\delta^{15} \mathrm{~N}$ stable isotope signatures of the main invertebrates and fish at the sandy $C$. nodosa habitats. In the MPA, the $\delta^{13} \mathrm{C}$ values went from Boops boops (-18.56 \pm 0.12$)$ to Dactylopterus volitans ($16.41 \pm 0.21)$, whilst in the non-protected area the ranges went from Boops boops ($18.86 \pm 0.12)$ to Diplodus vulgaris $(-13.03 \pm 0.14)$. Mixing models show that fish's food sources differ at the MPAs and fished sites. For Xyrichtys novacula in the MPA, the most important prey were polychaetes (percentage contribution: $0.433 \pm 0.082$ ) and the fish Bothus podas (percentage contribution: $0.375 \pm 0.021$ ) whilst in the non-protected area, the sum of amphipods and bivalves (percentage contributions of $0.244 \pm 0.147$ and $0.267 \pm 0.154$,
\end{abstract}


respectively) constituted the main food source. This indicates trophic plasticity of the predatory fish, leading to cascading effects on the benthic invertebrates. The present results highlight the relevance of disentangling protection effects from habitat effects, while providing evidence of the need to perform multi-species approaches to protection from fishing.

Key words: Food webs, Cymodocea nodosa, Stable isotopes, Marine Protected Area, Balearic Islands

Acknowledgments: This work was supported by the research project "Avaluació $i$ seguiment dels recursos marins de la CAIB 2008-2009" of Direcció General de Pesca (Balearic Islands). We appreciate the collaboration of the Mar-i-Pi II crew, and J.L. Lakarra for their help during field sampling, and the collaboration for the isotopic analysis of B. Martorell (Serveis Científico-Tècnics, University of the Balearic Islands) and M. Ribas (IUNICS). 


\title{
ESTIMATION OF THE ECOLOGICAL NICHE OF THE MURICEA GENUS (OCTOCORAL) IN THE GULF OF CALIFORNIA, B.C.S (MEXICO)
}

\author{
A. Aldrich*1, C. Sanchez ${ }^{2}$, M. González ${ }^{1}$, A. Beylán² and O. García ${ }^{2}$ \\ ${ }^{1}$ IOCAG-QUIMA, Universidad de Las Palmas de Gran Canaria, Las Palmas, SPAIN. \\ ariadna.aldrich101@alu.ulpgc.es,melchor.gonzalez@ulpgc.es \\ ${ }^{2}$ Marine and Coastal Sciences, Universidad Autónoma Baja California Sur, La Paz, MÉXICO. \\ csabchez@uabcs.mx,a.beylan@hotmail.com,b.m.omargc@gmail.com
}

\begin{abstract}
The Gulf of California (GC) is categorized into three regions (upper, central and lower) that differ in their physical, chemical, topographical and biological conditions, counting with different abundances of species (Santamaría et al., 1994). The Upper Gulf (UG) is characterized by a greater variety of species and primary productivity compared to the other two regions. The Muricea genus, for instance, shows a larger distribution in the UG and near the Great Islands (Tiburón and Ángel de la Guarda), whereas its distribution decreases at lower latitudes (i.e. in the mouth of the gulf or lower gulf) (Ulate et al., 2016). It is important to determine the main environmental variables that affect the distribution of a species for its conservation and management. Hence, the objective of this research is to determine the environmental factors that affect the distribution of Muricea genus in the GC by indicating their presence-absence and abundance. 155 reefs were surveyed using $30 \times 1$ $\mathrm{m}$ visual transects parallel to the coast, during years 2009, 2010 and 2013. Ten selected regions of the GC were selected, dividing into each region shallow and deep zones. Species Distribution Models (SDMs) were developed to be able to study thirteen species of octocorals, all within the Muricea genus (Soberón and Nakamura, 2009). Generalized Linear Models (GLM) were used to estimate the significant variables that explain the SDMs (Nelder and Wedderburn, 1972). The main factors that influence the spatial distribution of Muricea species in the GC were determined, and therefore, this study can be used in further research to predict and infer their range distribution and inform the conservation and management decisions on the possible response of Muricea species to environmental changes.
\end{abstract}

Key words: Ecological Niche, Muricea, Generalized Linear Models, Species Distribution Models, Environmental variables

Acknowledgements: The authors thank University of Baja California Sur (UABCS), Mexico, and the University of Las Palmas de Gran Canaria (ULPGC), Spain, for making this research possible. 


\section{References:}

Nelder, J.A. and Wedderburn, R.W.M. (1972). Generalized Linear Models. Journal of the Royal Statistical Society. Series A (General), 135 (3), 370.

Santamaría, E., Alvarez Borrego, S. and Müller Karger, F.E. (1994). Gulf of California biogeographic regions based on coastal zone color scanner imagery. Journal of Geophysical Research, 99 (C4), 7411.

Soberón, J. and Nakamura, M. (2009). Niches and distributional areas: Concepts, methods, and assumptions. Proceedings of the National Academy of Sciences, 106 (Suppl. 2), 19644-19650.

Ulate, K., Sánchez, C., Sánchez-Rodríguez, A., Alonso, D., Aburto-Oropeza, O. and Huato-Soberanis, L. (2016). Latitudinal regionalization of epibenthic macroinvertebrate communities on rocky reefs in the Gulf of California. Marine Biology Research, 12 (4), 389-401. 


\title{
STABLE OXYGEN ISOTOPES REVEAL THE HABITAT USE OF MARINE MAMMALS IN THE AREA OF INFLUENCE OF THE RÍO DE LA PLATA ESTUARY
}

\author{
M. Drago*1, M. Valdivia², D. Bragg1, E.M. González ${ }^{2}$, A. Aguilar $^{1}$ and L. \\ Cardona ${ }^{1}$ \\ ${ }^{1}$ Department of Evolutionary Biology, Ecology and Environmental Sciences and Institute of \\ Biodiversity Research (IRBio), University of Barcelona, Barcelona, SPAIN. \\ m.drago@ub.edu,danielbraggmarmol@gmail.com,aaguilar@ub.edu,luis.cardona@ub.edu \\ ${ }^{2}$ National Museum of Natural History, Montevideo, URUGUAY. \\ meicavaldivia@gmail.com,emgonzalezuy@gmail.com
}

\begin{abstract}
Knowledge about habitat use by marine mammals is of great importance for understanding and defining their ecological role in the ecosystem and for adequate management (Franklin, 1993; Roman and Estes, 2018). Here, we assess the habitat use patterns of thirteen marine mammal species along the salinity gradient of the Rio de la Plata estuary and adjoining south-western Atlantic Ocean using the ratios of oxygen stable isotopes in bone carbonate (apatite) as a proxy for salinity. Furthermore, we compare the results with those emerging from the distance of the stranding site to the innermost point within the estuary. The overall evidence indicates that stable oxygen isotopes can be good tracers of habitat use, allowing us to discern whether the species make a regular use of inshore estuarine-coastal or offshore pelagic-oceanic waters. On the contrary, sampling location does not provide a good characterization of the species habitat since other factors can be involved in the transport of the animals to stranding sites far from their normal habitat. In conclusion, the results are consistent with habitat use patterns previously described for the species considered in this study and demonstrate that stable isotopes of oxygen represent a useful and inexpensive approach to study habitat use in marine mammals.
\end{abstract}

Key words: Marine mammals, Stable oxygen isotopes, Habitat preferences, Stranding sites.

Acknowledgments: The study was funded by the Fundació Barcelona Zoo (Spain) through the Research and Conservation Programme - PRIC (309998). We also thank the Secretaria d'Universitats i Recerca del Departament d'Empresa i Coneixement de la Generalitat de Catalunya (Spain) for supporting M. Drago with a Beatriu de Pinós postdoctoral fellowship (2016 BP 00151). 


\section{References:}

Franklin, J.F. (1993). Preserving biodiversity: species, ecosystems, or landscapes? Ecological Applications, 3, 202-205

Roman, J. and Estes, J.A. (2018). Ecology. In: Würsig, B., Thewissen, J.G.M. and Kovacs, K.M. (Eds.), Encyclopedia of Marine Mammals, Third Edition. Academic Press, San Diego, 299-303. 


\title{
SEASONAL PATTERNS OF BODY CONDITION AND STABLE ISOTOPES OF TWO SMALL PELAGIC FISH ALONG A LATITUDINAL GRADIENT OF THE NORTHWESTERN MEDITERRANEAN SEA
}

\author{
E. Lloret-Lloret*1, M. Albo-Puigserver ${ }^{1}$, J. Giménez ${ }^{1,2}$, J. Navarro ${ }^{1}$, M.G. Pennino³ \\ J.M. Bellido ${ }^{4}$ and M. Coll ${ }^{1}$ \\ ${ }^{1}$ Department of Renewable Marine Resources, Institute of Marine Science (ICM-CSIC), Barcelona, \\ SPAIN. \\ elloret@icm.csic.es,albo@icm.csic.es,joan.gimenez@csic.es,joan@icm.csic.es,mcoll@icm.csic.es \\ ${ }^{2}$ Centre for Marine and Renewable Energy (MaREI), Marine Ecology Group, Environmental \\ Research Institute, University College Cork, Ringaskiddy, Co. Cork, IRELAND. \\ joan.gimenez@csic.es \\ ${ }^{3}$ Instituto Español de Oceanografía, Centro Oceanográfico de Vigo, 36202 Vigo, SPAIN. \\ grazia.pennino@ieo.es \\ ${ }^{4}$ Instituto Español de Oeanografía (IEO), Centro Oceanográfico de Murcia, 30740 San Pedro del \\ Pinatar, Murcia, SPAIN. \\ josem.bellido@ieo.es
}

\begin{abstract}
Small pelagic fish are key elements for the functioning of the marine food webs. In recent decades, these species have shown important changes in terms of biomass, landings, growth and body condition in the Northwestern Mediterranean Sea (Saraux et al., 2019). Despite recent studies, seasonal and spatial information about changes in biological and ecological traits of these species is still missing. In this study, we analyse the temporal patterns of body condition, reproduction period and trophic ecology of two important Mediterranean small pelagic fish, the European anchovy (Engraulis encrasicolus) and the European sardine (Sardina pilchardus), along a latitudinal gradient in the Northwestern Mediterranean Sea. Individuals of both species were sampled monthly in three areas along the Catalan coast (Roses, Barcelona and Tarragona harbours) during a complete year. Fatmeter values (measure of lipid content) were recorded and Kn (relative condition index) and GSI (gonadosomatic index) were calculated. We also measured the stable isotope composition $\left(\delta^{13} \mathrm{C}\right.$ and $\left.\delta^{15} \mathrm{~N}\right)$ to assess the trophic ecology at spatial and seasonal scales. Results revealed spatial and temporal variations for both species in terms of body condition. Kn and fatmeter peaked during the months of March to August for sardines, with a high accumulation of reserves before the reproduction period due to the capital breeding behaviour of this species. GSI values of sardines were high from September to February with higher GSI values in Barcelona and Roses than in Tarragona. Instead, anchovies, being income breeders (Albo-Puigserver et al., 2017), presented lower seasonal variability on fat reserves and $\mathrm{Kn}$ and maximum GSI values from May to September, with a peak of reproduction in July and a shorter reproduction period in Roses. Isotopic values also showed seasonal variations for both species with differences between areas. In general, we observed better body condition for both species when compared to studies from 2013 (Albo-Puigserver et al., 2019), probably related to food availability. This
\end{abstract}


multidisciplinary approach provides insights into the interplay of the energetic distribution and feeding behaviour of two highly commercial small pelagic fish in the Mediterranean Sea, along a latitudinal gradient and can be of use to understand the fluctuations on their population dynamics and recent trends.

Key words: Small pelagic fish, Trophic ecology, Body condition, Fatmeter, Stable isotopes

Acknowledgments: E.L.-L.was supported by a FPU grant (FPU1704395, Spanish Ministry of Education associated). J.N. was supported by the Spanish National Program Ramon y Cajal (RYC-2015-17809). This study is a contribution to the project PELWEB (CTM2017-88939R, Ministry of Science and Innovation, Spain).

\section{References:}

Albo-Puigserver, M., Muñoz, A., Navarro, J., Coll, M., Pethybridge, H., Sánchez, S. and Palomera, I. (2017). Ecological energetics of forage fish from the Mediterranean Sea: seasonal dynamics and interspecific differences. Deep-Sea Resarch II: Topical Studies in Oceanography 140: 74-82.

Albo-Puigserver, M. (2019). Ecological and functional role of small and medium pelagic fish in the northwestern Mediterranean Sea. Ph. D. Thesis, Polytechnic University of Catalonia, 209 p.

Saraux, C., Van Beveren, E., Brosset, P., Queiros, Q., Bourdeix, J.H., Dutto, G., ... and Fromentin, J.M. (2019). Small pelagic fish dynamics: A review of mechanisms in the Gulf of Lions. Deep Sea Research Part II: Topical Studies in Oceanography 159, 52-61. 


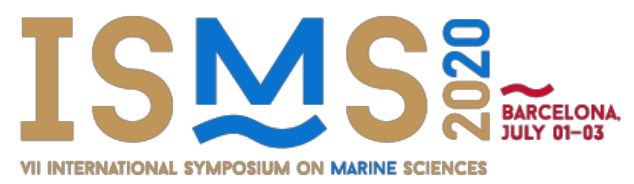

VII International Symposium on Marine Sciences

ISMS 2020

Barcelona (Spain), $1^{\text {st }-3^{\text {rd }} \text { July } 2020}$

\title{
VARIATIONS IN WATER MASSES OF THE EASTERN \\ MEDITERRANEAN SEA DURING THE LAST SAPROPEL (S1) INFERRED FROM NEODYMIUM ISOTOPIC COMPOSITION IN FORAMINIFERA
}

\author{
H. Checa*1,2, G. Margaritelli ${ }^{3}$, L.D. Pena ${ }^{1}$, J.N. Pérez-Asensio ${ }^{4}$, A. Català ${ }^{1}$, E.

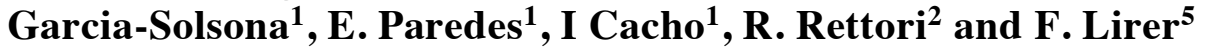 \\ ${ }^{1}$ GRC Geociències Marines, Departament de Dinàmica de la Terra i de l'Oceà, Universitat de \\ Barcelona, Barcelona, SPAIN. \\ helena.checa@ub.edu,lpena@ub.edu,al_catala@ub.edu,e.garcia@ub.edu, \\ eduardo.paredes@ub.edu,icacho@ub.edu \\ ${ }^{2}$ Facoltà di Geologia, Università degli Studi di Perugia, Perugia, ITALY. \\ helena.checasanchez@studenti.unipg.it,roberto.rettori@unipg.it \\ ${ }^{3}$ Istituto di Ricerca per la Protezione Idrogeologica (IRPI-CNR), Consiglio Nazionale delle \\ Ricerche, Perugia, ITALY. \\ giulia.margaritelli@irpi.cnr.it \\ ${ }^{4}$ Centre Européen de Recherche et d'Enseignement des Géosciences de l'Environnement \\ (CEREGE), Aix-en-Provence cedex 4, FRANCE. \\ perez@cerege.fr \\ ${ }^{5}$ Istituto di Scienze Marine (ISMAR)-CNR - Sede di Napoli, Consiglio Nazionale delle Ricerche, \\ Napoli, ITALY. \\ fabrizio.lirer@cnr.it
}

\begin{abstract}
Sapropels are organic-rich sedimentary layers. They occur in the Eastern Mediterranean Sea as a response to deep-sea anoxic events. Sapropel deposition has been attributed to increased biological production and/or deep water stagnation. Recent studies documented changes of the Mediterranean thermohaline circulation (MedTHC) during these anoxic events. However, there is a knowledge gap on the Adriatic and Ionian seas, which extend over a key area for the formation of the Eastern Mediterranean Deep Water (EMDW). Here we present a reconstruction of the changes of the MedTHC circulation system during Sapropel 1 (S1; 10.8-6.1 kyrs BP) as recorded in sediment core ND14Mbis, from $665 \mathrm{~m}$ depth on the North Ionian Sea, by using $\mathrm{Nd}$ isotope $(\varepsilon \mathrm{Nd})$ as a paleocirculation tracer. The intermediate depth waters present in our study area results from the mixing of two main end-member water masses, the Adriatic Deep water (ADW) and the Levantine Intermediate Water (LIW). The measured $\varepsilon N d$ reflects changes on the mixing percentages of these end-members during the different phases of the sapropel. $\varepsilon N d$ data allows defining $\mathrm{S} 1 \mathrm{a}$ and $\mathrm{S} 1 \mathrm{~b}$ as periods with reduced contribution of ADW to the intermediate water mass. Further support to the $\varepsilon N d$ data comes from U/Mn ratios in foraminifera authigenic coatings, as well as from changes in benthic foraminifera assemblages. The comparison of U/Mn and benthic foraminifera assemblage's data with
\end{abstract}


$\varepsilon N d$ data indicates that changes in the intensity of deep water convection preceded the establishment of dysoxic conditions in bottom waters and also the pulses of organic matter export. We conclude that a change in the circulation pattern of the Eastern Mediterranean Basin took place during S1, which was characterized by a weakening of the formation cell of ADW allowed an enhanced arrival of LIW to the northern Ionian Sea.

Key words: Sapropel S1, Mediterranean thermohaline circulation, Benthic foraminiferal assemblages, $\varepsilon \mathrm{Nd}$

Acknowledgments: Core ND14Mbis was collected by ISMAR-CNR (Napoli) aboard of the CNR-Urania research vessel during the NEXTDATA-2014 oceanographic cruise. Therefore, we are grateful to ISMAR-CNR for collecting the studied core. This research has been financially supported by the ERC-Consolidator TIMED project (REP-683237) and the Project of Strategic Interest NextData PNR 2011-2013 (http://www.nextdataproject.it/). 


\title{
VULNERABILITY OF POSIDONIA OCEANICA DEEP MEADOW LIMITS TO REMOTE WASTE DISCHARGES
}

\author{
Jiménez-Casero, $\mathrm{J}^{* 1}$, Conde-Caño, $\mathbf{M}^{2}$, Bernardeau-Esteller, $\mathbf{J}^{2}$, Marín-Guirao, $\mathbf{L}^{2}$ \\ Ruiz, $\mathbf{J M}^{2}$. \\ ${ }^{1,}$ Department of Marine Sciences and Applied Biology, University of Alicante, Alicante, SPAIN. \\ judit.jimenez@ua.es \\ ${ }^{2}$ Seagrass Ecology Group, Oceanographic Center of Murcia, Spanish Institute of Oceanography, \\ San Pedro del Pinatar, SPAIN. \\ mrcc0008@red.ujaen.es,jaime.bernardeau@ieo.es,lazaro.marin@ieo.es,juanm.ruiz@ieo.es
}

\begin{abstract}
:
Waste discharges into coastal waters have the potential to trigger direct and indirect interactions in seagrass communities, impacting plant fitness and survival, and altering the structure and functioning of the whole ecosystem (Burkholder et al., 2007). Slow growing species, such as Posidonia oceanica, are extremely sensitive to water quality deterioration, especially at the deep meadow margins where plants are close to their minimum light requirements.

In recent decades, organic wastes discharges from human activities have been reallocated away from $P$. oceanica meadows to protect and conserve these valuable habitats. Nonetheless, the influence of remote organic discharges on deep meadow limits has evidenced the need to establish "safety distances" for these offshore discharges (Ruiz et al. 2010).
\end{abstract}


We aimed at determining the remote influence of wastes discharges from sewage treatment plants and aquaculture facilities on the deep limit of a large $P$. oceanica meadow (26-28 $\mathrm{m}$ depth). To that end, the spatial variation of a wide set of plant and meadow descriptors was studied along a gradient of pressure determined by the distance to discharge points.

Results showed the influence of wastes discharges on deep meadow limits, as well as signs of impact at different levels of biological organization depending on the distance of the limit to discharge points. The nitrogen content and isotopic signatures $\left(\delta^{15} \mathrm{~N}\right)$ of epiphytes, leaves and rhizomes integrated the influence of organic wastes at different time scale evidencing their utility for monitoring purposes. On the other hand, some plant descriptors (nutrient content and plant size) suggest a negative effect of metals accumulation and plant performance. Our findings evidenced that wastes discharge relocation offshore from $P$. oceanica meadows may not be sufficient to conserve deep meadow areas, stressing the importance of monitoring these vulnerable meadow limits for their adequate management and conservation.

Key words: Posidonia oceanica, lower limit, eutrophication, aquaculture facilities, urban wastes

\section{Acknowledgments:}

This research was funded by the POSINET2 project of the Spanish Institute of Oceanography and the Department of Fishery and Aquaculture of the Regional Ministry of Agriculture and Water of the Murcia Region: Monitoring network of Posidonia oceanica meadow and climate change of the Murcia Region.

\section{References:}

Burkholder, J.M., Tomasko, D.A. and Touchette, B.W. (2007). Seagrasses and eutrophication. Journal of Experimental Marine Biology and Ecology, 350 (1), 46-72. 
Ruiz, J.M., Marco-Méndez, C., and Sánchez-Lizaso, J.L. (2010). Remote influence of off-shore fish farm waste on Mediterranean seagrass (Posidonia oceanica) meadows. Marine environmental research, 69 (3), 118-126. 


\title{
FEEDING ECOLOGY OF BLACKMOUTH CATSHARK GALEUS MELASTOMUS RAFINESQUE, 1810 IN THE PORCUPINE BANK (NE ATLANTIC)
}

\author{
Lola Riesgo*1, Francisco Baldó ${ }^{2}$ and José L. Varela ${ }^{3}$ \\ ${ }^{1,2}$ Instituto Español de Oceanografía, C.O. de Cádiz, SPAIN. \\ lola.riesgo@hotmail.es,francisco.baldo@ieo.es \\ ${ }^{3}$ Departamento de Biología, Universidad de Cádiz, SPAIN. \\ joseluis.varela@uca.es
}

\begin{abstract}
Trophic ecology studies of top predator species, such as elasmobranchs, is crucial to understand their ecological role. Here, we present preliminary results on the feeding habits of the blackmouth catshark, Galeus melastomus, a small bottom-dwelling shark widely distributed in the northeast Atlantic. This species is the most abundant shark of the Porcupine Bank (west of Ireland), where it is caught as by-catch in fisheries targeting Merlucius merlucius, Lophius spp and Lepidorhombus spp. Being an important predator, it may play a fundamental role in the regulation of organisms located at low trophic in the Porcupine Bank ecosystem. In order to characterize its feeding habits, stomach contents of 118 individuals, ranging between 25 and $77 \mathrm{~cm}$ in total length, were analysed. These specimens were caught in a research trawl survey conducted on the bank in September 2019 at depth ranging from 200 to $800 \mathrm{~m}$. The diet was analysed considering size and depth variations. Prey mainly belonged to three groups categories: krill (mainly composed by Meganyctiphanes norvegica and Nematoscelis megalops), decapod crustaceans and ommastrephid squids. It is worth to note that similar results were found in the Mediterranean, southern Bay of Biscay, and northeastern Atlantic Ocean. Although crustaceans were the most abundant prey species of the blackmouth catshark, their importance decreased with size. This is probably related to the fact that this shark shows bathymetric segregation. Thus, younger specimens inhabit shallower waters $(<450 \mathrm{~m})$, whereas older ones occur deeper waters $(>450 \mathrm{~m})$, allowing them to reduce intraspecific competition.
\end{abstract}

Key words: Sharks, Blackmouth catshark, Porcupine Bank, Feeding ecology, Stomach contents.

Acknowledgments: The authors would like to thank the staff involved in the Spanish Bottom Trawl Survey on the Porcupine Bank (SP-PORC-Q3), which has been part funded by the EU through the European Maritime and Fisheries Fund (EMFF). Also, thanks to Dr. J.A. Cuesta for contributing to the taxonomic identification of crustacean species. 


\title{
THE VARIED DIET OF THE SEA SLUG DORIS KERGUELENENSIS IN DECEPTION ISLAND (SOUTH SHETLAND IS., ANTARCTICA)
}

\author{
P. de Castro-Fernández*1, J. Giménez ${ }^{2}$, C. Avila ${ }^{3}$ and L. Cardona ${ }^{4}$ \\ ${ }^{1,3,4}$ Department of Evolutionary Biology, Ecology and Environmental Sciences \& Institute of \\ Research in Biodiversity (IRBio), Faculty of Biology, University of Barcelona, Barcelona, \\ CATALONIA, SPAIN. \\ p.decastro@ub.edu,conxita.avila@ub.edu,luis.cardona@ub.edu \\ ${ }^{2}$ MaREI Centre for Marine and Renewable Energy, Environmental Research Institute, University \\ College Cork, Ringaskiddy, Cork, IRELAND. \\ gimenez.verdugo@gmail.com \\ ${ }^{2}$ Department of Renewable Marine Resources, Institut de Ciències del Mar (ICM-CSIC), \\ Barcelona, SPAIN. \\ gimenez.verdugo@gmail.com
}

\begin{abstract}
Doris kerguelenensis is an Antarctic heterobranch mollusc feeding on several demosponges and hexactinellid sponges. To assess the contribution of several sponge species to its diet at Deception Island we used stable isotopes of $\mathrm{C}$ and $\mathrm{N}$, as well as fatty acids. We examined the demosponges Axinella crinita, Dendrilla antarctica, Hemigellius pilosus, Kirkpatrickia variolosa, Mycale acerata, Sphaerotylus antarcticus, and Haliclona sp. We also analyzed the macroalgae Desmarestia anceps and Himantothallus grandifolius, and phytoplankton. D. anceps was the most ${ }^{13} \mathrm{C}$ depleted one and phytoplankton the most enriched. The $\delta^{13} \mathrm{C}$ values of sponges and D. kerguelenensis laid in between. The $\delta^{15} \mathrm{~N}$ values of $A$. crinita, D. antarctica, M. acerata and Haliclona sp. suggested a trophic position between 2-3, and for H. pilosus and S. antarcticus between 34. Kirkpatrickia variolosa was in between the two groups. The $\delta^{15} \mathrm{~N}$ values of $D$. kerguelenensis revealed a trophic position from 3-4. All sponges and D. kerguelenensis had high levels of 15:0 and EPA and low levels of arachidonic acid, largely differing from macroalgae. Fatty acid profiles of $A$. crinita, D. antarctica, $K$. variolosa, $M$. acerata, $S$. antarcticus, and Haliclona sp. were similar to phytoplankton, but D. kerguelenensis and $H$. pilosus were enriched in 17:0, 20:1n9 and 20:2. D. kerguelenensis, A. crinita, D. antarctica, K. variolosa, Haliclona sp. and S. antarcticus shared a long chain fatty acid absent in phytoplankton and macroalgae. The overall evidence suggests that $A$. crinita, $D$. antarctica, $K$. variolosa and Haliclona sp. are the most likely prey of D. kerguelenensis at Deception Island.
\end{abstract}

Key words: Stable isotopes, Fatty acids, Gastropod molluscs, Porifera, Southern Ocean 


\title{
TEMPORAL DYNAMICS OF AMPHIPOD POPULATIONS ASSOCIATED WITH BIOFOULING IN COASTAL AQUACULTURE FACILITIES
}

\author{
S. Navarro-Mayoral*1, P. Sánchez-Jérez ${ }^{2}$ and V. Fernández-González² \\ ${ }^{1}$ Grupo en Biodiversidad y Conservación, IU-ECOAQUA, Universidad de Las Palmas de Gran \\ Canaria, SPAIN. \\ sandraanm16@gmail.com \\ ${ }^{2}$ Department of Marine Sciences and Applied Biology, University of Alicante, SPAIN. \\ victoria.fernandez@ua.es,psanchez@ua.es
}

\begin{abstract}
The expansion of marine aquaculture in the last decades involves an anthropogenic transformation of coastal areas, also influencing the ecosystems surrounding the facilities. The introduction of artificial structures results in an increase of available hard substrate prone to colonization by a diversity of marine organisms subsequently leading to biofouling. In the Mediterranean Sea the main sessile colonizing organisms are bivalves (mussels), algae and hydrozoans giving rise to new habitats providing refuge and food to the associated epifauna. It is very common finding free-living organisms such as crustaceans, within which amphipods have been described as one of the most abundant groups given their ability to colonize new substrata. However, the study of amphipods in aquaculture facilities and their relationship with the species that make up biofouling communities is very scarce. The work here presented focuses in the temporal variability of the total abundance of amphipods associated to biofouling created by the mussel Mytilus galloprovincialis in order to determine population fluctuations of the two most abundant species, Elasmopus rapax and Caprella equilibra. Two aquaculture facilities in the southwestern Mediterranean Sea were sampled bi-monthly from 2010 to 2011 by scuba diving. In each sampling, the mooring ropes of the mussels' cages were scraped and the released organisms collected using an airlift device. Both investigated species were present throughout the year, with population fluctuations marked by environmental factors such as temperature or habitat heterogeneity. Similar temporal dynamics were obtained in the two facilities with regard to abundance of amphipods. The highest amphipod densities were found in the cold season, whereas the lowest ones occurred in the warmer months.
\end{abstract}

Key words: Aquaculture, Amphipods, Temporal dynamics, Biofouling, Mytilus galloprovincialis. 


\title{
Pinna rudis Linnaeus, 1758: THE FASTEST GROWTH REPORTED FOR A BIVALVE
}

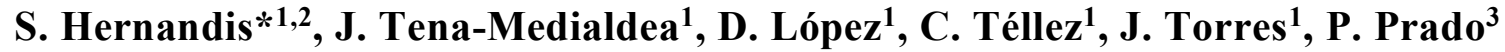 \\ and J.R. García-March ${ }^{1}$
}

${ }^{1}$ Instituto de Investigación en Medio Ambiente y Ciencia Marina (IMEDMAR-UCV), Universidad Católica de Valencia SVM, 03710 Calpe, Alicante, SPAIN. sebastia.hernandis@ucv.es,josetena@ucv.es,diana.lopez@ucv.es, clara.tellez@ucv.es, javier.torres@ucv.es,jr.garcia@ucv.es

${ }^{2}$ Escuela de Doctorado, Universidad Católica de Valencia San Vicente Mártir, SPAIN.

${ }^{3}$ IRTA-Aquatic Ecosystems, Sant Carles de la Ràpita, Tarragona, SPAIN. patricia.prado@irta.cat

\begin{abstract}
The growth of Pinna rudis was studied in cages suspended in the water column during a period of 2 years in the marine area adjacent to the Natural Park of Penyal d'Ifac in Calpe, Spain. In order to avoid predation, self-burial and possible interference by fishermen a total of 40 juveniles of $P$. rudis were placed within individual plastic mesh boxes at $15 \mathrm{~m}$ depth, and $5 \mathrm{~m}$ above the bottom. The length and width of all individuals was periodically measured to the nearest millimetre (every 3-5 weeks depending on sea conditions), using Vernier callipers. Oceanographic parameters (Dissolved Oxygen, pH, Chlorophyll $a$, turbidity, salinity and temperature) from water column profiles were measured bimonthly in the immediacy of the cages. Individuals showed the fastest monthly and annual growth ever reported for a bivalve. The maximum length growth registered for a single juvenile (individual A1.2) over a period of 26 days was $34.31 \mathrm{~mm}$ $\left(1.32 \mathrm{~mm} \mathrm{~d}^{-1}\right)$ and occurred in July 2018. Similarly, the maximum average growth was recorded in July 2018 (26 days) with shells increases of $20.83 \pm 5.45 \mathrm{~mm}$ and $13.83 \pm 4.19$ $\mathrm{mm}$, respectively for length and width. In contrast, the maximum width growth (individual A3.2) attained over a period of 22 days (a total of $31.00 \mathrm{~mm}, 1.41 \mathrm{~mm} \mathrm{~d}^{-1}$ ) occurred in December 2018. At the annual level, the maximum growth detected was $209.00 \mathrm{~mm}$ in length $\left(0.57 \mathrm{~mm} \mathrm{~d}^{-1}\right)$ and $132.2 \mathrm{~mm}$ in width $\left(0.36 \mathrm{~mm} \mathrm{~d}^{-1}\right)$, respectively for individuals A1.1. and C5.2. On average, the maximum annual growth was $166.59 \pm 19.99 \mathrm{~mm}$ length and $106.14 \pm 15.55 \mathrm{~mm}$ width. Until now, the maximum monthly and annual growth rates ever reported for a bivalve were $1 \mathrm{~mm} \mathrm{~d}^{-1}$ (Richardson et al., 1999) and $0.32 \mathrm{~mm} \mathrm{~d}^{-1}$ (Kersting and Garcia-March, 2017) in Pinna nobilis.
\end{abstract}

Key words: Aquaculture, bivalve, growth rate

Acknowledgments: This research was partially funded by the Prince Albert II of Monaco Foundation under the project BF/HEM 15-1662 "The study, protection and possible 
breeding of pen shell (Pinna nobilis) in the Boka Kotorska Bay". We are grateful to Andromeda group who enabled the collection of the $P$. rudis juveniles and the "Conselleria d'Agricultura, Medi Ambient, Canvi Climatic i Desenvolupament Rural" for their permission to collect the juveniles.

\section{References:}

Kersting, D.K. and Garcia-March, J.R. (2017). Long-term assessment of recruitment, early stages and population dynamics of the endangered Mediterranean fan mussel Pinna nobilis in the Columbretes Islands (NW Mediterranean). Mar. Environ. Res. 130, 282-292.

Richardson, C.A., Kennedy, H., Duarte, C.M., Kennedy, D.P. and Proud, S.V. (1999). Age and growth of the fan mussel Pinna nobilis from south-east Spanish Mediterranean seagrass (Posidonia oceanica) meadows. Marine Biology 133 (2), 205-212. 


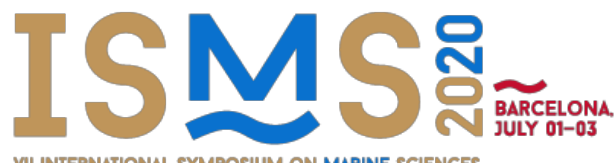 \\ VII INTERNATIONAL SYMPOSIUM ON MARINE SCIENCES
}

\section{INFLUENCE OF THE WATER'S PHYSICOCHEMICAL CHARACTERISTICS ON THE FORAMINIFERA BIOCENOSIS IN THE SPANISH CONTINENTAL SHELF}

\author{
U. Muñoz Berruezo, A.J. Molera Arribas, A.M Blázquez Morilla \\ Environmental and Marine Sciences Research Institute (IMEDMAR), Catholic University of \\ Valencia. Valencia, C/Guillem de Castro 94, 46003 Valencia, Spain. \\ uxuemube@mail.ucv.es,ale.mole@mail.ucv.es,ana.blazquez@ucv.es
}

\begin{abstract}
This study was carried out on board the R/V Sarmiento de Gamboa, during a journey between the ports of Tarragona and Vigo, in early December 2019. During the transit, sampling was performed in both Mediterranean and Atlantic waters with a Multisampler Multicorer (KC Denmark). The first centimeter of the corer was stained with rosa bengal in order to determine the live assemblages of benthic foraminifera. Samples were sifted and ordered taxonomically according to Loeblich \& Tappan's classification (1987) and Hayward et al. (2017). A minimum of 100 benthic-stained shells (live foraminifera) were obtained, and so the statistical tests were representative (Fatella \& Taborda, 2002). The physicochemical measurements were obtained from CTD profiles. These parameters were correlated with the foraminifera associations obtained.
\end{abstract}

The benthic-dyed (live) species included Hanzawaia boueana (d'Orbigny), Globocassidulina crassa (d'Orbigny), Uvigerina peregrina Cushman, Globobulimina pyrula (d'Orbigny) and Hyalinea balthica (Schröter in Gmelin), which are common in deep waters and in muddy and sandy bottoms (Murray, 1991). The presence of this assemblage is associated with the physicochemical measurements recorded in the CTD profiles. Planktonic species included Globoconella inflata (d'Orbigny), Globorotalia truncatulinoides (d'Orbigny), Globigerina bulloides d'Orbigny, Globigerinoides ruber (d'Orbigny) and Orbulina universa d'Orbigny. The ratio between stained (live) and unstained (dead) foraminifera was similar to that recorded in other studies carried out on the valencian continental shelf (Usera \& Blázquez, 1997). The results also corroborate the ratio of planktonic and benthic foraminifera depending on depth determined by Murray (1991).

Key words: Foraminifera, Biocenosis, Shelf, Physicochemical measurements.

Acknowledgments: This study was carried out as part of a campaign promoted and funded by the Commission for the Coordination and Monitoring of Oceanographic Vessel Activities (COCSABO), the Ministry of Science and Innovation, and the Maritime Technical Unit (UTM). We thank these institutions for the opportunity to join the expedition and obtain samples for our studies. We also thank the crew of the R/V Sarmiento de Gamboa and the technical staff of the UTM for all the support provided during the campaign, and all the scientists involved in the collection of samples, both at the Catholic University of Valencia and at the University of Cádiz. 


\section{References:}

Loebich. A.R.Jr. \& Tappan, H. (1987). Foraminiferal Genera and their Classification. Van Nostrand Reinhold Company, New York, 970 pp.

Fatela, F. \& Laborda, R. (2002). Confidence limits of species proportions in microfossil assemblages. Marine Micropaleontology, 45, 169-174.

Hayward B.W., Cedhagen T., Kaminski M. (2017). World Foraminifera Database. Accessed on 2017-03-24 at http://www.marinespecies.org/foraminifera.

Murray, J. W. (1991). Ecology and Paleoecology of Benthic Foraminifera. Longman Scientific and Technical. $397 \mathrm{p}$.

Usera J. \& Blázquez, A.M. (1997). Influencia del sustrato en la distribución y ecología de los foraminíferos bentónicos de la plataforma continental interna entre Valencia y Alicante (España). Revista Española de Micropaleontología. Vol. XXIX, 2: 85-104 


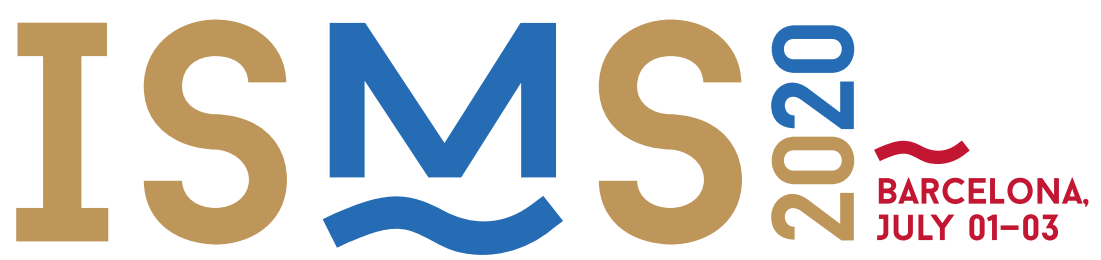

VII INTERNATIONAL SYMPOSIUM ON MARINE SCIENCES

\section{POSTER \\ COMMUNICATIONS}

\section{MARINE \\ GEOSCIENCES}




\title{
THE HOLOCENE RECORD OF THE ALMENARA MARSH, CASTELLON, SPAIN
}

\author{
M. Nieto-Pérez ${ }^{* 1}$ and A.M. Blázquez-Morilla ${ }^{1}$ \\ ${ }^{1}$ Environmental and Marine Sciences Research Institute, Catholic University of Valencia, 46003 \\ Valencia, SPAIN. \\ mar.nieto@mail.ucv.es,ana.blazquez@ucv.es
}

\begin{abstract}
The study area is the Almenara marsh, south of the province of Castellón, located on a tectonically stable segment (Mediato, 2016) of the Spanish Mediterranean coast. The original extension of the marsh has been reduced because of siltation caused by natural processes and anthropogenic activities, and is today about 1,500 ha (Rodríguez Pérez et al., 2018). This wetland has recently been included in the RAMSAR Convention (the Convention on Wetlands) due to its noticeable biodiversity.
\end{abstract}

Here we present the results of the analysis of a $9.3 \mathrm{~m}$ long sediment core (S-6) obtained at $39^{\circ} 45^{\prime} 51^{\prime \prime} \mathrm{N} 0^{\circ} 9^{\prime} 47^{\prime} \mathrm{O}$. The sediments were ${ }^{14} \mathrm{C}$ dated and their micropaleontological record (benthic forams) and sedimentological properties (grain size, organic matter and carbonate content) examined in order to investigate climate variations, sea level oscillations and other paleoenvironmental changes in the area during the Holocene.

The most abundant foraminifera species are Ammonia beccarii (Linnaeus), Ammonia tepida (Cushman), Rosalina globularis d'Orbigny, Elphidium crispum (Linnaeus) and Elphidium excavatum (Terquem). Foraminifera assemblages allowed identifying three paleoenvironmental units. At the bottom of the core, the record shows a shallow coastal environment from the Holocene marine transgression, which reached its maximum level around 5,455 yr BP according to ${ }^{14} \mathrm{C}$ dating of remains of Posidonia oceanica. Subsequently, the progressive relative sea level lowering led to the formation of a peat deposit in a marsh. The uppermost unit corresponds to the modern soil.

Key words: Holocene, Paleoenvironmental record, Foraminifera, Almenara marsh

Acknowledgments: This study was supported by UCV/2017-153-001, UCV/2018153002, from Catholic University of Valencia.

\section{References:}

Mediato, J. (2016) Oscilaciones del nivel del mar desde el Pleistoceno superior en el sector costero SaguntoBenicasim (Valencia-Castellón): registro sedimentario, geoquímico e histórico. Universidad Complutense de Madrid.

Rodríguez-Pérez, A. (2017) Evolución Holocena del marjal de Almenara: cambios eustáticos y climáticos. PhD Thesis, Universidad Católica de Valencia 'San Vicente Mártir'. 


\title{
PHYSICO-CHEMICAL CHARACTERIZATION OF A SUBMARINE MINE TAILINGS DEPOSIT OFF PORTMÁN BAY (SE SPAIN) BY USING NON-DESTRUCTIVE TECHNIQUES
}

\author{
Andrea Baza-Varas* ${ }^{* 1}$, Jaime Frigola ${ }^{1}$, Marc Cerdà-Domènech ${ }^{1}$, Anna Sànchez ${ }^{1}$ \\ and Miquel Canals ${ }^{1}$ \\ ${ }^{1}$ Dept. of Earth and Ocean Dynamics, Faculty of Earth Sciences, Barcelona, SPAIN. \\ a.baza@ub.edu,jfrigola@ub.edu,cerda.domenech@ub.edu,anna.sanchez@ub.edu, \\ miquelcanals@ub.edu
}

\begin{abstract}
Direct dumping into the sea of mine tailings from an open pit exploitation of $\mathrm{Pb}-\mathrm{Zn}$ ores in Sierra de Cartagena during $33 \mathrm{yr}$ led to the infilling of Portmán Bay and subsequent seaward shoreline advance. Whereas several investigations have contributed to the characterization of the subaerial portion of the mine tailings deposit, little information is available from the submerged part. With this purpose 27 gravity cores were obtained during the 2018 NUREIEVA-MAR1 research cruise. The materials in these cores have been analysed by means of non-destructive techniques, such as Multi Sensor Core Logging (MSCL) and XRF Core Scanner for physical and geochemical properties, respectively. Together with high-resolution images, those measurements allowed identifying four main sedimentary units. From bottom to top, Unit 1 consists of light-colored, bioclast-rich finemedium sands indicative of pre-dumping inner shelf sedimentation. Unit 2, which only appears in some cores, is composed of brown-dark grey silty clays with abundant black patches. All measured physical properties in this unit display homogeneous values, jointly with a relative increase of metals. Unit 2 would represent the first stages of mine tailings accumulation on the seabed, mostly made of fine grained particles. Unit 3 is made of highly laminated clayey silts punctuated by dark sand layers, with physical properties showing generally high and oscillating values. This unit also presents high quantities of metals like $\mathrm{Fe}, \mathrm{As}, \mathrm{Pb}$ and $\mathrm{Zn}$ together with $\mathrm{S}$. Unit 3 corresponds to the mine tailings in stricto senso. Finally, the uppermost Unit 4 is composed of bioturbated homogeneous sandy silts with values for most of the measured physical properties generally diminishing upwards. This unit results from the reworking of materials from the top of the tailings deposit mixed with post-dumping sedimentary particles. The integrated analysis of the measured parameters also allows identifying the distribution of the main units in the mine tailings and, therefore, to reconstruct the history of the entire waste deposit.
\end{abstract}

Key words: Portman Bay, mine tailings, coastal contamination

Acknowledgments: this work has been carried out in the framework of the Spanish RTD project NUREIEVA (ref. CTM2016-75953-C2-1-R). CRG on Marine Geosciences is recognized by Gen. de Catalunya in its program for excellence research groups (ref. 2017 SGR 315). Andrea Baza-Varas acknowledges financial support from a PhD fellowship by 
Universitat de Barcelona (UB). 


\title{
THE ALMANZORA-ALÍAS-GARRUCHA CANYON SYSTEM: SEISMIC PROCESSING AND SEDIMENTARY FEATURES
}

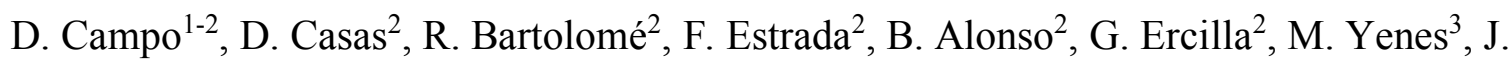
Nespereira $^{3}$, N. López-González ${ }^{4}$, D. Casalbore ${ }^{5} \&$ Fauces cruises teams.

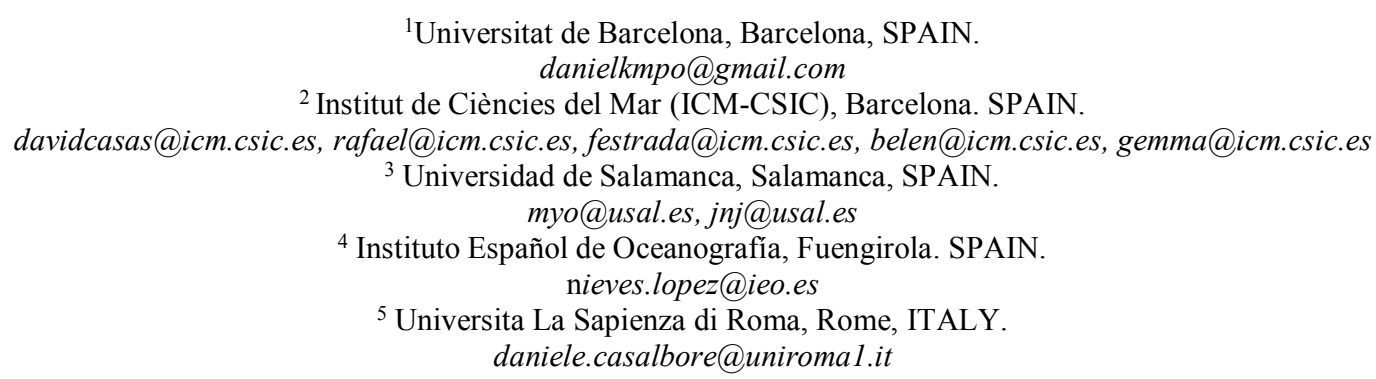

\begin{abstract}
The $74 \mathrm{~km}$ long Almanzora-Alías-Garrucha canyon system is one of the most important submarine canyons located in the Palomares continental margin (SW Mediterranean Sea). The canyon head and upper course are constituted by several tributaries such as Almanzora, Garrucha, Cabrera and Alias canyons from $\mathrm{N}$ to $\mathrm{S}$.

During 3 recent oceanographic cruises, different multibeam echosounder datasets were merged and also an extensive network of parametric profiles was recorded to study the canyon. A total of 1519 nautical miles of parametric profiles (TOPAS and Parasound P-35, penetration $<150 \mathrm{~m}$ ) were acquired in order to characterize the main morphological features and to map the eco-facies defining the deposits and sedimentary processes along the different canyon domains, included its margins. The parametric profiles have been processed after the deconvolution of the continuous $4 \mathrm{kHz}$ Carrier wave pulse acquired using a source wavelet extracted from the data itself. Processing steps include automatically picking of the seafloor, burst noise removing, time-frequency noise attenuation, spherical divergence correction, butterworth and 2D spatial filtering. Finally, reflection strength (envelope of the signal) has been calculated and time-variant amplitude corrected for displaying and interpretation.

Different sedimentary features such as bedforms, mass-movement deposits, erosive surfaces, fluid dynamic features and contourites have been defined. Most of tributaries show a progressive indentation and features observed in the upper courses are related to the erosive processes e.g. a dense network of dendritic gullies and minor scars and falls affecting the canyon walls. The seafloor of the southern margin is highly irregular defining an area that extends from 600 to 2240 mwd affected by a mass flows deposits composite. In contrast, the northern margin presents a set of nested concave-downward scars, with a W-E trend, and lengths of 2 to $8 \mathrm{~km}$.
\end{abstract}

Key words: Submarine canyon, eco-facies, seismic processing.

Acknowledgments: FAUCES Project (CTM2015-65461-C2-1-R/ C2-2-R) is acknowledged by the data provided and support for this work. 


\title{
GEOMORPHOLOGICAL SUBMARINE FEATURES IN THE MENORCA CHANNEL (WESTERN MEDITERRANEAN)
}

\author{
D. Palomino ${ }^{1}$, N. Martinez-Carreño ${ }^{1}$, D. Díaz ${ }^{2}$, S. Ramírez-Amaro², \\ M. T. Farriols², E. Marco-Herrero², U. Fernández-Arcaya ${ }^{2}$, A. Muñoz $^{2}$, S. Mallol $^{2}$, \\ J. A. Díaz ${ }^{2}$, F. Ordines ${ }^{2}$, N.R. de la Ballina ${ }^{2}$, J. T. Vázquez ${ }^{1}$ and E. Massutí*2 \\ ${ }^{1}$ Instituto Español de Oceanografía, Centro Oceanográfico de Málaga, Fuengirola, SPAIN. \\ desiree.palomino@ieo.es,natalia.martinez@ieo.es, juantomas.vazquez@ieo.es \\ ${ }^{2}$ Instituto Español de Oceanografía, Centre Oceanogràfic de les Balears, Palma, SPAIN. \\ david.diaz@ieo.es,sergio.ramirez@ieo.es,mt.farriols@ieo.es,elena.marco@ieo.es, \\ ulla.fernandez@ieo.es,anabel.mcaballero@ieo.es,sandra.mallol@ieo.es,julio.diaz@ieo.es, \\ xisco.ordinas@ieo.es,nuria.rodriguez@ieo.es,enric.massuti@ieo.es
}

\begin{abstract}
:
Based on geophysical (multibeam echosounder and very high resolution parametric profiles) and sedimentological (Shipek dredge) data acquired during the INTEMARESCANAL0419 expedition, different geomorphologic features have been identified. The study area is located in the continental shelf of the Menorca Channel between 37 and 116 $\mathrm{m}$ water depth (mwd). Shallower zones are dominated by lense shaped bedforms, up to 1 $\mathrm{m}$ high. They are characterized by very low backscatter values. Also small circular -or slightly elongated- mounds are very frequent morphologies occurring up to $100 \mathrm{mwd}$. Their sizes range from 1 to $5 \mathrm{~m}$ high and 20 to $80 \mathrm{~m}$ of diameter with high backscatter values. The most prominent morphological features at intermediate depths are a set of channels that dig in the shelf from 60 to $90 \mathrm{mwd}$. They show vertical walls and extend up to several $\mathrm{km}$. In the parametric profiles, paleochannels filled by a sedimentary layer approximately $30 \mathrm{~ms}$ (two-way time) thick can be observed. The deepest zones are characterized by an erosive surface covered by a thin layer of no consolidated sediments. A visual analysis of the samples shows that sediments are characterized by coarse sand and gravel mainly composed of biogenic particles (carbonated fragmented bioclasts). Higher values of backscatter correspond to samples with a variable abundance of rhodoliths whereas lower values correspond to sands. The variety of morphological features can be mainly related to erosive and depositional Quaternary processes in the continental. Benthic communities strongly influence sediment composition, which was found to be characterized by a high carbonate content.
\end{abstract}

Key words: geomorphology, carbonated sediments, sedimentary processes, Menorca Channel, Balearic Island

Acknowledgments: We thank the captain and the crew of the R/V Ángeles Alvariño for their assistance during the expedition. This study is a contribution to LIFE IP INTEMARES (LIFE15/IPE/ES/000012). S.R.A. and J.A.D activities are co-funded by the Regional Government of the Balearic Islands and the European Social Fund. 


\title{
NOVEL ISOTOPIC TRACERS IN MARINE SCIENCES: NEODYMIUM AND BORON ANALYSIS AT NANOGRAM LEVELS
}

\author{
E. Paredes*1,2, L.D. Pena ${ }^{1}$, E. Garcia-Solsona ${ }^{1}$, E. Calvo ${ }^{3}$, C. Pelejero ${ }^{3,4}$ \& I. \\ Cacho $^{1}$ \\ ${ }^{1}$ GRC Geociències Marines, Departament de Dinàmica de la Terra i de l'Oceà, Facultat de \\ Ciències de la Terra, Universitat de Barcelona, Spain. \\ ${ }^{2}$ Centres Científics i Tecnològics de la Universitat de Barcelona, Carrer de Lluís Solé i Sabarís, 1, \\ 08028 Barcelona, Spain. \\ ${ }^{3}$ Institut de Ciències del Mar, CSIC, Passeig Marítim de la Barceloneta, 37-49, E-08003 Barcelona, \\ Catalonia, Spain \\ ${ }^{4}$ Institució Catalana de Recerca i Estudis Avançats, Barcelona, Catalonia, Spain \\ eduardo.paredes@ub.edu,lpena@ub.edu,e.garcia@ub.edu,ecalvo@icm.csic.es, \\ carles.pelejero@icrea.cat,icacho@ub.edu
}

\begin{abstract}
Recent advancements in mass spectrometry allow the possibility to measure precise and accurate isotopic ratios of different elements present in the ocean with very low natural abundances (nanograms). This opens a new realm of possibilities in the Marine Sciences. In this regard, neodymium and boron isotopes are becoming nowadays solid tools to study the ocean both during present day and past times.

Neodymium isotopes in seawater are used as tracers of modern ocean circulation, whereas the analysis of marine sedimentary substrates (foraminifera, corals and fish teeth) provides information about the effect of past climate changes on ocean circulation. Boron speciation in seawater is determined by the $\mathrm{pH}$, leading to a modification of the $\mathrm{B}(\mathrm{OH}) 4$ - isotopic signature as a result of ocean acidification processes. Since $B(\mathrm{OH}) 4-$ is incorporated into carbonates, boron isotopes in foraminifers and corals are used to reconstruct past changes in ocean acidification and the associated atmospheric pCO2 levels.

Owing to the small size of some of these samples and the high precision of isotope ratio results required for these applications, special care must be taken during sample preparation and analysis in order to obtain high quality results. This is now possible at the University of Barcelona thanks to two newly available facilities (LIRA and PANTHALASSA). LIRA (Laboratori d'Isòtops Radiogènics i Ambientals) is a metal-free clean laboratory with certified ISO 5 air quality, whereas PANTHALASSA is the last generation Plasma 3 MultiCollector Inductively Coupled Plasma Mass Spectrometer. With these two facilities we have setup methods for the high-precision isotopic analysis of neodymium and boron in samples containing only a few nanograms of these elements.
\end{abstract}

Key words: Radiogenic Isotopes, Ocean circulation, Acidification, Isotopic tracers.

Acknowledgments: This work has received funding from the European Research Council (ERC) under the European Union's Horizon 2020 research and innovation programme (ERC-Consolidator project TIMED, Grant agreement No. 683237). The authors also thank 
the financial support from the MINECO (CHIMERA project, CTM2016-75411-R). 


\title{
STUDY OF THE SUBMARINE CANYONS ON THE INSULAR MARGIN OF GRAN CANARIA
}

\author{
Gómez-Molina A. ${ }^{1}$, Montoya-Montes I. ${ }^{2,3}$, Sánchez-García M.J. ${ }^{3}$ and Alonso I. ${ }^{* 4}$ \\ ${ }^{1}$ Universidad de Las Palmas de Gran Canaria, Las Palmas de Gran Canaria, SPAIN. \\ alberto.gomez106@alu.ulpgc.es \\ ${ }^{2}$ Instituto Geológico y Minero de España, Unidad de Canarias. Las Palmas de Gran Canaria, \\ SPAIN. \\ i.montoya@igme.es \\ ${ }^{3,4}$ Instituto de Oceanografía y Cambio Global IOCAG, Universidad de Las Palmas de Gran \\ Canaria, Las Palmas de Gran Canaria, SPAIN. \\ mariajose.sanchez@ulpgc.es,ignacio.alonso.bilbao@ulpgc.es
}

\begin{abstract}
Submarine canyons are the most common type of underwater valleys on the continental and island margins. Such geomorphic features are of the utmost relevance because of the high biodiversity and the valuable living resources they host. Also, infill deposits of ancient submarine canyons are a classical target as hydrocarbon reservoirs. Here we present the results of a GIS-based morphometric analysis and classification of the submarine canyons incised on the margins of Gran Canaria Island. In total, 190 submarine canyons have been identified, 139 of which are blind (slope-confined) canyons whereas the remaining 51 are shelf-incising canyons. Two qualitative variables (location of the canyon head and channel section shape) and nine quantitative ones (number of branches, length, sinuosity, head depth, mouth depth, depth difference between head and mouth, head slope, mouth slope and general slope of the canyon) have been calculated for each canyon in order to characterize the entire set. There is some degree of correlation between the calculated parameters and the overall slope of the insular margin. We conclude that the origin and development of the investigated submarine canyons have been controlled by multiple geological and oceanographic processes, such as tectonics, volcamism and mass-wasting.
\end{abstract}

Key words: Gran Canaria, submarine canyons, multibeam bathymetry, geomorphic analysis 


\title{
BEDFORM MAPPING WITH SIDE SCAN SONAR: A TOOL FOR STUDYING SEDIMENT DYNAMIC STUDIES IN CÍES ISLANDS, GALÍCIA
}

\author{
Joel Calviño ${ }^{* 1}$, Irene Alejo ${ }^{1}$ and José González ${ }^{2}$ \\ ${ }^{1}$ Department of Marine Geosciences, Marine Science Faculty, University of Vigo, SPAIN. \\ jcalvino@alumnos.uvigo.es,ialejo@uvigo.es \\ ${ }^{2}$ Oceanography Unit, ECIMAT-CIM, University of Vigo, SPAIN. \\ josegonzalez@uvigo.es
}

\begin{abstract}
The main objective of this work is studying the bedforms patterns developed over the subtidal sand banks of the eastern side of Cíes Islands (Ría de Vigo, NW Iberian Peninsula) in order to characterise the sedimentary bodies and to achieve information on currents and wave dynamics over this area. The study focuses in four areas: 1) the subtidal area of San Martiño Beach, 2) an area south of Faro Island, 3) the central segment of Rodas Beach, and 4) the northern segment of Rodas Beach. Two surveys were carried out to analyse the variability of bedform patterns in November 2018, after the summer period, and in April 2019 , following the winter period, which is characterised by highly energetic events. 21 Startfish side scan sonar (SSS) transects were recorded and processed with Hypack Marine Search and YellowFin 2.015 software allowing us producing SSS mosaics where to identify and classify bedforms. Bathymetric profiles were recorded with a Sonarmite echosounder along the same transects. A GoPro camera, a Trident ROV and scuba diving at selected points, where sediment samples were collected, provided a wealth of seabed images. Generally speaking, we identified two main groups of bedforms: a) large sandbars and mega-ripples normal to the coastline associated to tidal currents, and b) smaller mega-ripples and ripples parallel to the coastline associated to incident waves. Whereas bedforms are more defined and larger after more energetic periods, our results show an essentially constant general pattern for subtidal bedforms in all investigated areas, either following summer or winter conditions.
\end{abstract}

Key words: Subtidal bedforms, Sediment dynamics, Side scan sonar, Cíes Islands, Galícia

Acknowledgments: this study was partially founded by the XM1 research group GRC ED431 C 2017/55 (Xunta de Galicia) and the survey support of the technicians from the marine Unit of ECIMAT. 


\title{
OCEAN-ATMOSPHERE INTERCONNECTIONS FROM THE LAST INTERGLACIAL TO THE EARLY GLACIAL: AN INTEGRATION OF MARINE AND CAVE RECORDS IN THE IBERIAN REGION
}

\author{
J. Torner ${ }^{1}$, I. Cacho' ${ }^{1}$, A. Moreno ${ }^{2}$, F. J. Sierro ${ }^{3}$, B. Martrat ${ }^{4}$, J. Rodriguez- \\ Lazaro $^{5}$, J. Frigola 1 , P. Arnau ${ }^{6}$, Á. Belmonte ${ }^{7}$, J. Hellstrom ${ }^{8}$, H. Cheng', R.L. \\ Edwards ${ }^{9}$ and H. Stoll ${ }^{10}$ \\ ${ }^{1}$ Grup de Recerca Consolidat en Geociéncies Marines, Dept. de Dinàmica de la Terra i de l'Oceà, \\ Universitat de Barcelona, Barcelona, SPAIN. \\ j.torner@ub.edu,i.cacho@ub.edu,j.frigola@ub.edu \\ ${ }^{2}$ Pyrenean Institute of Ecology, CSIC, Zaragoza, SPAIN. \\ amoreno@ipe.csic.es \\ ${ }^{3}$ RG Oceanic Geosciences, Dept. of Geology, University of Salamanca, Salamanca, SPAIN. \\ sierro@usal.es \\ ${ }^{4}$ Dept. of Env. Chemistry, Inst. of Env. Assessment and Water Research (IDAEA-CSIC), \\ Barcelona, SPAIN. \\ belen.martrat@idaea.csic.es \\ ${ }^{5}$ Dept. of Stratigraphy and Paleontology, University of Basque Country UPV/EHU, Leioa, SPAIN. \\ julio.rodriguez@ehu.eus \\ ${ }^{6}$ Municipal Museum of Ciutadella, Menorca, SPAIN. \\ p.arnau@ajciutadella.org \\ ${ }^{7}$ Dept. of Geosciences, University of Zaragoza, Zaragoza, SPAIN. \\ ajbelmonte@educa.aragon.es \\ ${ }^{8}$ School of Earth Science, University of Melbourne, Melbourne VIC 3010, AUSTRALIA. \\ j.hellstrom@unimelb.edu.au \\ ${ }^{9}$ Dept. of Geology and Geophysics, University of Minnesota, MN 55455, USA. \\ edwar001@umn.edu,cheng021@umn.edu \\ ${ }^{10}$ Earth Science Department, ETH Zürich, Zurich, SWITZERLAND. \\ heather.stoll@erdw.ethz.ch
}

\begin{abstract}
This study explores the climatic variability in the Iberian Peninsula (IP) and its surrounding seas from 140 to $65 \mathrm{kyr}$ BP. Marine sediment cores and cave speleothems are used to reconstruct changes in sea surface water conditions, deep sea current intensities and atmospheric moisture availability based on stable isotopes, trace elements, grain size and XRF-elemental analyses. In terms of millennial-scale variability, the records trace the sequence of events defined for the North Atlantic region. The marine records show an intense sea-surface freshening and cooling related to Heinrich Event 11. During the Last Interglacial (LIG), the sea surface temperature evolution was heterogeneous around the IP with gradients larger than those from today. The LIG was coincident with an accelerated aridification phase that marked the glacial inception in a Minorca speleothem at $116.5 \mathrm{kyr}$
\end{abstract}


BP. This was the first of a series of stadial periods that punctuated the early glaciation and where the sea thermal gradient almost disappeared around the IP. These intense coolings during stadials led the development of drier and intense westerlies over southern European latitudes, reflected in a Pyrenees speleothem record, and favouring enhanced deep convection in the Western Mediterranean Sea. In contrast to this stadial regional homogeneity among the studied records, interstadial periods show rather heterogeneous patterns around the IP pointing to much complex ocean-atmosphere interconnections during warm intervals.

Key words: Interglacials, Western Europe, Speleothems, Marine sediment cores

Acknowledgments: This research was financially supported by CHIMERA (CTM201675411-R) and OPERA (CTM2013-48639-C2-1-R). We thank Generalitat de Catalunya Grups de Recerca Consolidats for grant 2017 SGR 315 to GRC Geociències Marines. We are grateful to M. Guart (Dept. de Dinàmica de la Terra i de l'Oceà, Universitat de Barcelona), M. Romero, T. Padró, B. Baena, J. Perona (Serveis Cientifico-Tècnics, Universitat de Barcelona) and A. Pascual (Dept. of Stratigraphy and Paleontology, University of the Basque Country UPV/EHU) for their help with the laboratory work. IC thanks the ICREA-Academia programme from the Generalitat de Catalunya. BM acknowledges support from the CSIC - Ramón y Cajal postdoctoral programme RYC2013-14073. JT benefited from an FPI-fellowship by MINECO. 


\title{
DEEP WATER MASS GEOMETRY IN THE SOUTH EAST ATLANTIC BASIN ACROSS THE MID-PLEISTOCENE TRANSITION
}

\author{
L.D. Pena ${ }^{1}$ and M. Jaume-Seguí ${ }^{1}$ \\ ${ }^{1}$ GRC Geociències Marines, Departament de Dinàmica de la Terra i de l'Oceà, Facultat de \\ Ciències de la Terra, Universitat de Barcelona, Barcelona, SPAIN. \\ lpena@ub.edu,mariajaume@ub.edu
}

\begin{abstract}
The Mid-Pleistocene Transition (MPT) stands as the largest reorganization of the Earth's climate system in the recent geological past. MPT refers to the interval 1.25$0.75 \mathrm{Ma}$ when the length of climate cycles shifted from 41,000 to 100,000 years. A simultaneous decrease in atmospheric CO2 (Honisch et al., 2009; Chalk et al., 2017) and in the intensity of the Atlantic Meridional Overturning Circulation (AMOC) across the MPT at $\sim 900$ ka (Pena and Goldstein, 2014) suggests that weakened deep-ocean circulation facilitates the capture of $\mathrm{CO} 2$ in the deep ocean (Farmer et al., 2019). Here we present new deep-ocean circulation proxies from site 668B in the deep eastern equatorial Atlantic. We present new benthic foraminiferal stable isotopes, trace elements $(\mathrm{B} / \mathrm{Ca}$, $\mathrm{Mg} / \mathrm{Ca}, \mathrm{Cd} / \mathrm{Ca})$, and $\mathrm{Nd}$ isotopes $(\varepsilon \mathrm{Nd})$ in foraminiferal coatings, extending to $\sim 2 \mathrm{Ma}$. At site $668 \mathrm{~B}, \varepsilon N d$ covaries with carbonate ion saturation index $\left(\Delta \mathrm{CO}_{3}{ }^{2-}\right)$ as derived from $\mathrm{B} / \mathrm{Ca}$ data, Bottom Water Temperatures (BWT, $\mathrm{Mg} / \mathrm{Ca}$ ) and deep ocean nutrient content $\left(\mathrm{PO}^{3-}\right.$ from $\left.\mathrm{Cd} / \mathrm{Ca}\right)$. Results show a higher fraction of warmer, less corrosive and nutrientpoor northern-sourced waters reaching the deep-equatorial Atlantic during interglacial periods compared to glacial periods. $\varepsilon \mathrm{Nd}$ and BWT data suggest an increased contribution of southern-sourced waters to the site during glacial periods after $0.9 \mathrm{Ma}$, as shown by a gradual decrease in glacial BWT and increasing glacial $\varepsilon N d$ values $(\sim 1 \varepsilon)$. Both $\mathrm{B} / \mathrm{Ca}$ and $\mathrm{Cd} / \mathrm{Ca}$ show distinctive low frequency variability superimposed to the glacial-interglacial variability. These oscillations can be interpreted as infiltrations of southern-sourced waters across the mid-ocean ridge into the SE Atlantic Basin, which do not completely follow glacial-interglacial periodicity. We propose that bathymetrical constrains exert a control on the chemistry of the deep waters in the eastern equatorial Atlantic with potential impacts on global climate. Partially isolated sub-basins such as the SE Atlantic could have effectively acted as carbon reservoirs over longer time scales than glacial-interglacial changes.
\end{abstract}

Key words: Mid-Pleistocene Transition, Nd isotopes, Trace elements, AMOC 
References: please follow the examples below

Chalk, T.B., Hain, M.P., Foster, G.L., Rohling, E.J., Sexton, P.F. et al. (2017). Causes of ice age intensification across the Mid-Pleistocene Transition. Proceedings of the National Academy of Sciences, 114 (50), 13114-13119.

Farmer, J.R., Hönisch, B., Haynes, L.L., Kroon, D., Jung, S. et al. (2019). Deep Atlantic Ocean carbon storage and the rise of 100,000-year glacial cycles. Nature Geoscience, 12 (5), 355-360.

Honisch, B., Hemming, N.G., Archer, D., Siddall, M. and cManus, J.F. (2009). Atmospheric carbón dioxide concentration across the Mid-Pleistocene Transition. Science, 324 (5934), 1551-1554.

Pena, L.D. and Goldstein, S.L. (2014). Thermohaline circulation crisis and impacts during the MidPleistocene Transition. Science, 345 (6194), 318-322. 


\title{
IMPACT OF THE EASTERN MEDITERRANEAN STAGNATION DURING THE LAST SAPROPEL IN THE DEEP SOUTH TYRRHENIAN BASIN
}

\author{
S. Trias-Navarro ${ }^{1,2}$, I. Cacho ${ }^{1}$, L.D. Pena ${ }^{1}$, M. De la fuente ${ }^{1}$, A. Català ${ }^{1}$, J. \\ Frigola $^{1}$, E. Paredes ${ }^{1}$, E. Garcia-Solsona ${ }^{1}$, A. Caruso ${ }^{2}$ and F. Lirer ${ }^{3}$ \\ ${ }^{1}$ Departament de Dinàmica de la Terra i de l'Oceà, Facultat de Ciències de la Terra, Universitat. de \\ Barcelona, 08028 Barcelona, SPAIN. \\ sergildt@gmail.com,icacho@ub.edu,lpena@ub.edu,mdelafuente@ub.edu,al_catala@ub.edu, \\ jfrigola@ub.edu,eduardo.paredes@ub.edu,e.garcia@ub.edu, \\ ${ }^{2}$ Dipartimento di Scienze della Terra e del Mare, Università degli studi di Palermo, 90123 \\ Palermo, ITALY. \\ antonio.caruso@unipa.it \\ ${ }^{3}$ Istituto di Scienze Marine-CNR, Sede Napoli, 80133, Napoli, ITALY. \\ fabrizio.lirer@cnr.it
}

\begin{abstract}
The Mediterranean Sea is a semi-enclosed sea formed by two sub-basins connected through the Strait of Sicily. Four main interconnected convection cells fuel the Mediterranean Thermohaline Circulation (Med-THC), which behaviour during past climate changes is not fully understood. The present study focuses on the analysis of sediment core NDT-6-2016 from the South Tyrrhenian Basin, which covers the last $14 \mathrm{kyr}$ cal. BP, and therefore, allows exploring two key events in the Med-THC: the last organic rich layer (ORL) and the last sapropel (S1), which took place diachronically in the Western and Eastern Mediterranean basins, respectively. NDT-6-2016 was recovered at $1066 \mathrm{~m}$ of water depth, which at present corresponds to the depth of the interphase layer in the region between water masses originating in both sub-basins. Therefore, this core was potentially suitable to evaluate changes in the properties of water masses transferred from the Eastern Basin to the Western sub-basin.
\end{abstract}

Changes in deep-water properties are reconstructed using a wide array of geochemical and sedimentological proxies. Elemental analyses in bulk sediment, as well as U/Mn measurements in planktonic foraminifera coatings, suggest the dominance of stable welloxygenated conditions over the last $14 \mathrm{kyr}$ cal. BP with some minor oscillations. However, $\delta^{18} \mathrm{O}$ and $\mathrm{Mg} / \mathrm{Ca}$ analyses in benthic foraminifera reveal significant changes in the physical properties of the deep waters, such as temperature and salinity, in agreement with the formation phases of the ORL and the S1, which are consistent with variations in the intensity of deep-water currents as suggested by grain-size analyses. $\mathrm{Nd}$ isotopes measured in planktonic foraminifera coatings indicate that the observed oceanographic changes might be related to changes in the export rates of Eastern Mediterranean sourced water masses into the South Tyrrhenian Sea. 
Key words: South Tyrrhenian Sea, Med-THC, sapropel S1, ORL, Nd isotopes

Acknowledgments: This research has been financially supported by ERC-TIMED project 525 (683237) and by NEXTDATA project (www.nextdataproject.it). 

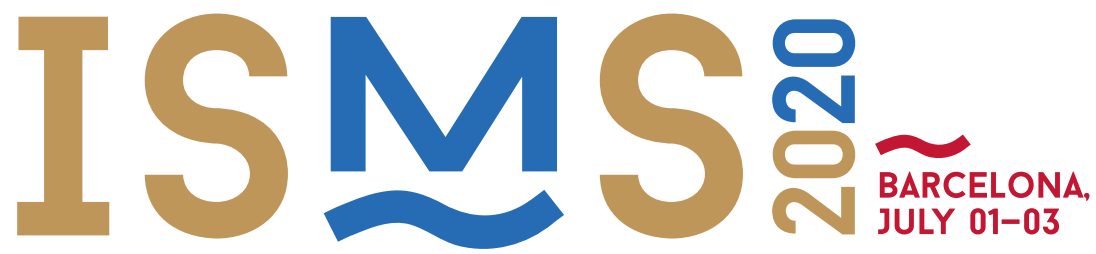

VII INTERNATIONAL SYMPOSIUM ON MARINE SCIENCES

\section{POSTER \\ COMMUNICATIONS}

\section{MICROBIOLOGY,}

GENETICS,

BIOTECHNOLOGY

AND MOLECULAR

BIOLOGY 


\title{
ABUNDANCE OF HYDROCARBONOCLASTIC BACTERIA IN THE TROPICAL AND SUBTROPICAL OCEAN
}

\author{
A. Salgado ${ }^{1}$, A. Martínez-Varela ${ }^{1}$, G. Cases-Papell ${ }^{1}$, J. Dachs ${ }^{1}$ and M. Vila-Costa $^{* 1}$ \\ ${ }^{1}$ Department of Environmental Chemistry, IDAEA-CSIC, Barcelona, Catalonia, SPAIN. \\ ana.salgado@idaea.csic.es,amvqam@cid.csic.es,gcpqam@cid.csic.es, \\ jordi.dachs@idaea.csic.es,mvcqam@cid.csic.es
}

\begin{abstract}
Polycyclic aromatic hydrocarbon (PAH) emissions, derived from fossil fuel combustion, have been exponentially released to the environment during the Anthropocene. Diffuse pollution of PAH to the global ocean by atmospheric deposition can account for large carbon fluxes (400 TgC y-1), exceeding the amounts released by any marine accidental spill (Gonzalez-Gaya et al., 2016).

Acute hydrocarbon marine pollution events have shown how the presence of high concentrations of PAHs can promote the growth of hydrocarbon-degrading specialists, known as hydrocarbonoclastic bacteria (HCB). HCB include members of the rare biosphere, indicating the presence of a seed bank of bacteria that can bloom under hydrocarbon-rich conditions (Kleindienst et al., 2016). However, it is yet unknown whether or not the yearly entrance of PAH by atmospheric deposition promotes changes in marine microbiomes, such as HCB enrichments under specific situations. In order to know if PAH biodegradation and the presence of HCB in the oceans is relevant at global scale, we performed qPCR amplifications of hydrocarbon degrading $\gamma$-Proteobacteria (Alcanivorax, Colwellia, Oleispira and Cycloclasticus) and the PAH ring-hydroxylating dioxygenase functional gene of the large data set generated during the Malaspina circumnavigation expedition. These observations emphasize the relevance of microbial degradation depleting surface background $\mathrm{PAH}$ concentrations. Our results highlight the potential linkage between in situ PAH concentrations and the presence of HCB as potential key players driving the fate of PAH in the ocean.
\end{abstract}

Key words: Polycyclic aromatic hydrocarbons, Hydrocarbonoclastic bacteria, Malaspina expedition, qPCR, Tropical ocean

Acknowledgments: The authors thank the support of RV Hespérides crew and UTM technicians during the cruise. This work was funded by the Spanish Government through the Malaspina 2010 Consolider-Ingenio 2010 program (ref. CSD2008-00077) and project ISOMICS (CTM2015-65691-R). The research group of Global Change and Genomic Biogeochemistry is supported by the Catalan Government (ref. 2017SGR800). 


\section{References:}

González-Gaya, B. et al. (2016). High atmosphere-ocean exchange of semivolatile aromatic hydrocarbons. Nature Geoscience, 9, 438-442.

Kleindienst, S. et al. (2016). Diverse, rare microbial taxa responded to the Deepwater Horizon deep-sea hydrocarbon plume. The ISME Journal, 10 (2), 400-415. 


\title{
EFFECT OF UV DISINFECTION ON WATER MICROBIOLOGY AND QUALITY OF A MEDITERRANEAN RECIRCULATED AQUACULTURE SYSTEM
}

\author{
E. Schoina* ${ }^{1}$, H. Miliou ${ }^{2}$ and G.-J. Nychas ${ }^{1}$ \\ ${ }^{1}$ Department of Food Science and Human Nutrition, Agricultural University of Athens, Athens, \\ GREECE. \\ eschoina@aua.gr,gjn@aua.gr \\ ${ }^{2}$ Department of Animal Science and Aquaculture, Agricultural University of Athens, Athens, \\ GREECE. \\ elenmi@aua.gr
}

\begin{abstract}
The microbial communities developed in Recirculated Aquaculture Systems (RAS) are of great importance for the function of the system and production stability. The aim of this study was to assess the effect of UV disinfection on the population of planktonic heterotrophic bacteria and general water quality in a marine RAS.

Experiments took place in a mature experimental marine RAS, where gilthead seabream and seabass were reared. Fish were fed 3 times per week. In the first experiment, UV disinfection system was constantly operating. After a $40 \%$ water renewal, daily microbiological samplings and water monitoring $\left(\mathrm{T}\right.$, salinity, $\mathrm{pH}, \mathrm{O}_{2}$, nitrite and total ammonia) were conducted in 9 compartments of the RAS for one week. Marine heterotrophic bacteria were enumerated with Marine Agar medium. The experiment was repeated disabling the UV disinfection system, keeping identical all other conditions.
\end{abstract}

The bacterial load was comparable in every sampling point in the RAS in both cases. When UV was operating, bacterial population $\left(\mathrm{CFU} \mathrm{mL} \mathrm{m}^{-1}\right)$ increased by $377 \%$ after $24 \mathrm{~h}$ of water renewal, decreased to initial level in $48 \mathrm{~h}$, and by the end of the week, it decreased further than the initial level. Disabling the UV system, a $1773 \%$ increase was observed in the first $24 \mathrm{~h}$. In $48 \mathrm{~h}$ the bacterial population had recovered but slightly augmented comparing to initial level, remaining relatively stable until the end. Also, $\mathrm{pH}$ value was steadily decreasing and loss of appetite and hyperventilation were observed in fish. In both treatments, a fluctuation of bacterial population and nitrogen waste products were observed to follow the feeding regime.. Overall, the utilization of UV disinfection denoted better fish rearing conditions.

Key words: Recirculated Aquaculture System, water microbiology, water disinfection

Acknowledgments: This project (IMPAQT) has received funding from the EU H2020 research and innovation programme under Grant Agreement No 774109. 


\title{
THE CONNECTIVITY BETWEEN POPULATIONS OF THE MARINE CRAB LIOCARCINUS DEPURATOR IN THE ATLANTO- MEDITERRANEAN TRANSITION: A FIVE YEAR SERIES
}

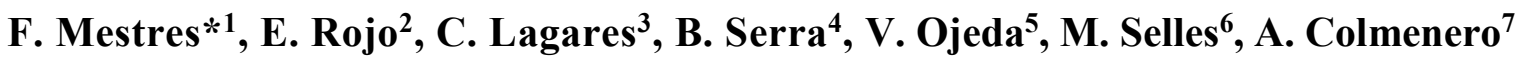 \\ Y. Vila ${ }^{8}$ and P. Abelló 9 \\ 1, 2,3,4,5,6,7 Department of Genetics, Microbiology and Statistics, Universitat de Barcelona, \\ Barcelona, SPAIN. \\ fmestres@ub.edu,evarojofrancas@gmail.com,claudia.lagares.m@gmail.com, \\ brunaserraelias@gmail.com,victor.ojma@gmail.com,mariaselles98@gmail.com, \\ ariadnacolmeneroc@gmail.com, \\ ${ }^{5}$ Centro Oceanográfico de Cádiz (IEO), Cádiz, SPAIN. \\ yolanda.vila@ieo.es \\ ${ }^{6}$ Institut de Ciències del Mar (ICM-CSIC), Barcelona, SPAIN. \\ pabello@icm.cisc.es
}

\begin{abstract}
We carried out a spatial and temporal genetic differentiation analysis using seven populations of the marine crab Liocarcinus depurator to elucidate the effect of three oceanographic discontinuities in the Atlanto-Mediterranean coast: Gibraltar Strait, Almeria-Oran Front and Ibiza Channel. To conduct this study, a 527 bp fragment of the mitochondrial COI gene was sequenced in individuals captured in the period 2014-2018 from the following Iberian coast populations: Cádiz, West Alboran, East Alboran, Alacant, Valencia, Ebro Delta and North Catalonia. Two haplogroups were detected; one characteristic of Atlantic waters and the other of Mediterranean, and their distribution allowed understanding the connectivity between populations. The effect of the oceanographic fronts on gene flow varied over time. Their effects were significant for the Gibraltar Strait (2014 and 2017), Almeria Oran Front (2013, 2014, 2015, 2016 and 2017) and Ibiza Channel (2015). Interestingly, the joint analysis of West Alboran, East Alboran and Alacant populations allowed detecting in a more precise scale the spatial location of the Almeria Oran Front. Finally, significant differences were observed in connectivity between Valencia and Ebro Delta in 2015, although there is not an oceanographic discontinuity between them. The main conclusion is that the gene flow is mediated by oceanographic fronts, but their intensity and effects change over time.
\end{abstract}

Key words: Liocarcinus depurator, connectivity, oceanographic fronts, COI

Acknowledgments: Ministerio de Economía y Competitividad, Spain (CTM2017-88080

AEI/FEDER, UE) (CTM2015-66400-C3-3-R MINECO/FEDER) and the Generalitat de Catalunya, Spain (2017 SGR 1120). 


\title{
SPATIAL GENETIC STUDY IN WESTERN MEDITERRANEAN POPULATIONS OF THE BATHYAL CRAB GERYON LONGIPES: VARIABILITY OF COI GENE
}

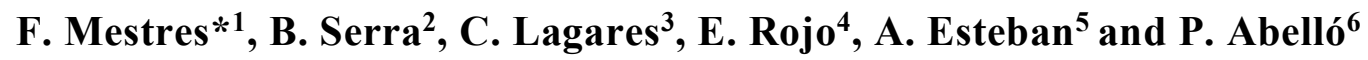 \\ 1, 2,3,4 Department of Genetics, Microbiology and Statistics, Universitat de Barcelona, Barcelona, \\ SPAIN. \\ fmestres@ub.edu,brunaserraelias@gmail.com,claudia.lagares.m@gmail.com, \\ evarojofrancas@gmail.com \\ ${ }^{5}$ Centro Oceanográfico de Murcia (IEO), San Pedro del Pinatar (Murcia), SPAIN. \\ antonio.esteban@ieo.es \\ ${ }^{6}$ Institut de Ciències del Mar (ICM-CSIC), Barcelona, SPAIN. \\ pabello@icm.cisc.es
}

\begin{abstract}
A fragment of $572 \mathrm{bp}$ of the cytochrome oxidase subunit I (COI) mitochondrial gene was analyzed to estimate the molecular variability in the bathyal crab Geryon longipes. From four Mediterranean locations (Barcelona, València, Alacant and Ibiza channel), twenty individuals were sequenced. Additionally, thirteen sequences from other geographic origins (Israel, Malta, Portugal and Scotland) were obtained from DNA databases for their use in this study. Only three polymorphic sites were observed, and interestingly one of them showed heteroplasmy. Haplotype (Hd) and nucleotide $(\pi)$ diversities were estimated as $0.487 \pm 0.091$ and $0.00124 \pm 0.00029$, respectively. Only four haplotypes were obtained: one main haplotype, a secondary one and two haplotypes found in few individuals only. A haplotype network was constructed showing that both main haplotypes were connected by only one substitution, whereas to reach any of the two remaining haplotypes, an intermediate one was needed. However, this intermediate haplotype was not detected in this research. Finally, the COI fragment studied would indicate that the samples from Scotland most likely belong to G. longipes.
\end{abstract}

Key words: Geryon longipes, COI, nucleotide diversity, haplotype distribution.

Acknowledgments: Ministerio de Economía y Competitividad, Spain (CTM2017-88080 AEI/FEDER, UE) (CTM2015-66400-C3-3-R MINECO/FEDER) and the Generalitat de Catalunya, Spain (2017 SGR 1120). 


\title{
AN OVERVIEW OF THE ENERGY METABOLISM DURING Aurelia aurita's LIFE CYCLE (FROM EPHYRA TO MEDUSA)
}

\author{
Martínez I.*, Bondyale-Juez D. R., Romero-Kutzner V., Herrera A., Packard \\ T.T., Gómez M. \\ Marine Ecophysiology Group (EOMAR). IU-ECOAQUA, Universidad de Las Palmas de Gran \\ Canaria, Canary Islands, Spain \\ ico.martinez@ulpgc.es,daniel.bondyale101@alu.ulpgc.es,vanesa.romero.kutzner@gmail.com, \\ alicia.herrera@ulpgc.es, theodore.packard@ulpgc.es,may.gomez@ulpgc.es
}

\begin{abstract}
:
The biochemical composition and energy metabolism of the organisms are important keys to reach a better understanding about the transfer of energy within an ecological community. In addition to that, during years gelatinous zooplankton such as jellyfish has been underestimated for the plankton community or trophic ecosystem models.

In this study, we explore the energy metabolism of cultured Aurelia aurita by means of cellular energy allocation approach (CEA index), the respiratory electron transport system activity (ETS), and organic analysis of lipids (Lip), carbohydrates (Carb) and proteins (Prot). We analysed these parameters during 66 days from ephyra to medusa. Individuals were fed with non-enriched Artemia 48h-nauplii once a day during all the culture time, measuring thus their 'basic metabolism'. CEA index is calculated as the ratio between energy available and energy consumption allowing us to evaluate the net energy budget during the different life stages of $A$. aurita. Carb was non-detected in most of the samples so the energy available $(\mathrm{Ea})$ was determined from Lip and Prot content $(\mathrm{Ea}=\mathrm{Lip}+$ Prot $)$. Energy consumption (Ec) was calculated from the activity of ETS. All the parameters were transformed into energy equivalents using their respective energy of combustion.

Protein and lipid content as well as ETS activity (J/mg DM and $\mathrm{J} / \mathrm{h} / \mathrm{mg}$ DM respectively) show a decreasing tendency with the age, and about day 40 of culture, all parameters seem to be stabilizing, maybe because they reach the adult stage. As for the CEA index, the Ea:Ec ratio was significantly higher during the first 10 days of culture, and also seems to stabilize from day 40 indicating a regulation of their energy metabolism when the organisms become an adult. On the other hand, from day 13 the main source of energy changes from lipids to protein, coinciding with the start of the process of transformation from ephyra to medusa.

Results obtained represent a first evaluation about the $A$. aurita metabolism during its life cycle. For a better understanding more studies are needed with a food regime closer to their natural environment.
\end{abstract}

Key words: Aurelia aurita, energy budget, CEA index, biochemical composition, ETS activity

Acknowledgments: The PERSEO project (ProID201710051) of the Canary Island government and ERDF funds granted to M.G. supported this study. 


\title{
MICROBIOME CHARACTERIZATION OF $M$. GALLOPROVINCIALIS ALONG A SPATIAL AND TEMPORAL ENVIRONMENTAL STRESS GRADIENT. \\ Margherita Musella*1, Elena Biagi ${ }^{1}$, Silvia Franzellitti ${ }^{2}$, Mauro Marini ${ }^{3}$, Gian Marco Luna ${ }^{3}$, Giorgia Palladino ${ }^{1}$ and Marco Candela ${ }^{1}$
}

\author{
${ }^{1}$ Unit of Holobiont Microbiome and Microbiome Engineering (HolobioME), Department of \\ Pharmacy and Biotechnology, Alma Mater Studiorum - University of Bologna, Bologna, Italy. \\ ${ }^{2}$ Animal and Environmental Physiology Laboratory, Department of Biological, Geological and \\ Environmental Sciences (BiGeA) - University of Bologna, Ravenna, Italy. \\ ${ }^{3}$ National Research Council - CNR-IRBIM, Ancona, Italy. \\ margherita.musella2@unibo.it,elena.biagi@unibo.it,silvia.franzellitti@unibo.it, \\ mauro.marini@cnr.it,gianmarco.luna@cnr.it,giorgia.palladino2@unibo.it, \\ marco.candela@unibo.it
}

\begin{abstract}
:
Mediterranean mussels (Mytilus galloprovincialis) have a relevant economic value as a species of interest in worldwide aquaculture. Particularly, North-Western Adriatic Sea is characterized by prominent mussel farming activity [1]. The combination of shallow waters, restricted circulation and high riverine inputs [2] make its coastal areas as one of the most eutrophic and productive in the Mediterranean. This environment is also affected by strong anthropogenic activities (river emission from agricultural sites, maritime transport, fishing and tourism). Such conditions make mussel farms excellent field laboratories to explore the connection between the health and productivity of farmed mussels and the environmental quality. Hence, given the increasing perception of the importance of mussel microbiomes for host health and productivity [3,4], the aim of this study is to find patterns of adaptive/maladaptive response to anthropogenic and environmental stress, along a spatial and temporal stress gradient. To characterize the symbiont microbial ecosystems of farmed mussels, a 16S rRNA gene sequencing approach was adopted. 450 samples, separated in digestive gland and gill tissues, were collected in winter, spring and summer (December April - August 2019) from 3 commercial farms located in Goro (near the Po delta: high nutrient load and pollution), Cattolica (160 Km from the Po delta) and Senigallia (200 Km from the Po delta: low nutrient load and pollution). Our preliminary results indicate a relevant degree of microbiome plasticity in the different mussel tissues. Indeed, in each tissue, we have been successful in describing characteristic microbiome variations in response to seasonality and for a given season to the proximity to the Po river. Even if results need to be confirmed on a larger sample set, our preliminary results highlight the potential of mussel-associated microbiomes to act as an adaptive player, allowing the host to optimize is immunological and metabolic layout in response to the environmental conditions.
\end{abstract}

Key words: Mediterranean mussel microbiome, 16s rDNA amplicon sequencing, 
microbiome-environment interactions

\section{Acknowledgments:}

This work was supported by the "Controlling Microbiomes Circulations for Better Food Systems" (CIRCLES) project, funded by the European Union's Horizon 2020 research and innovation program under grant agreement no. 818290. We would like to thank Associazione Mediterranea Acquacoltori (AMA) for their support in the collection of the mussel samples.

\section{References:}

[1] Brigolin, D., Porporato, E.M.D., Prioli, G., Pastres, R., 2017. Making space for shellfish farming along the adriatic coast. ICES J. Mar. Sci. 74, 1540-1551. https://doi.org/10.1093/icesjms/fsx018.

[2] Marini, M., Jones, B.H., Campanelli, A., Grilli, F., Lee, C.M., 2008. Seasonal variability and Po 519 River plume influence on biochemical properties along western Adriatic coast. J. Geophys. 520 Res. Oceans 113, C05S90. https://doi.org/10.1029/2007JC004370.

[3] O'Brien, P.A., Webster, N.S., Miller, D.J., Bourne, D.G., 2019. Host-microbe coevolution: applying 541 evidence from model systems to complex marine invertebrate holobionts. MBio 10. pii: 542 e02241-18. https://doi.org/10.1128/mBio.02241-18.

[4] Rausch, P., Rühlemann, M., Hermes, B.M., Doms, S., Dagan, T., Dierking, K., et al., 2019. 564 Comparative analysis of amplicon and metagenomic sequencing methods reveals key features 565 in the evolution of animal metaorganisms. Microbiome 7, 133. https://doi.org/10.1186/s40168- 566 019-0743-1. 


\title{
POPULATION GENOMICS AND HIERARCHICAL ANALYSES REVEAL GENETIC STRUCTURE AND ADAPTATION IN PARACENTROTUS LIVIDUS (ECHINOIDEA)
}

\author{
M. Pascual ${ }^{1}$, C. Carreras ${ }^{1}$, A. García-Cisneros ${ }^{1,2}$, O.S. Wangensteen ${ }^{3}$, V. \\ Ordóñez ${ }^{1}$, C. Palacín ${ }^{1}$ and X. Turon ${ }^{2}$ \\ ${ }^{1}$ Facultat de Biologia-IRBio, Universitat de Barcelona, 08028 Barcelona, SPAIN. \\ martapascual@ub.edu,carreras@ub.edu,alexgarcia.cis@gmail.com, \\ vosanchez@gmail.com,cpalacin@ub.edu \\ ${ }^{2}$ Centre d'Estudis Avançats de Blanes (CEAB, CSIC), 17300 Blanes, SPAIN. \\ xturon@ceab.csic.es \\ ${ }^{3}$ Norwegian College of Fishery Science, University of Tromsø, Tromsø, NORWAY. \\ owenwangensteen@gmail.com
}

\begin{abstract}
The Atlanto-Mediterranean edible purple sea urchin Paracentrotus lividus is a commercially exploited keystone species in benthic communities. Its browsing activity can deeply modify the littoral landscape and changes in its abundance are of major conservation concern. Nowadays, this species is facing contrasting anthropogenic pressures and its management requires knowledge of its genetic structure, connectivity, and local adaptation. We used genotyping by sequencing (GBS) of 241 individuals belonging to 11 populations spanning the known range of distribution of this species across the Atlantic-Mediterranean transition, from Morocco and France to Turkey. We obtained 3,348 loci for population genomics and outlier analyses. We identified significant genetic structure and a gradient matching the longitudinal position of the localities. Two main clusters (Atlantic and Mediterranean) were detected, and a hierarchical analysis revealed subtler patterns of differentiation within them. Candidate markers for selection identified between and within these two main clusters were mostly different, likely indicating different selective pressures. Adaptation to maximum salinity and maximum temperature appeared as an important driver of the transition between Atlantic and Mediterranean basins. Other stressors, such as minimum temperature or range of temperature, seem to define the structuring within the Mediterranean. Our study shows the potential of hierarchical analyses on population genomics to detect fine scale genetic structure and adaptation signatures of marine species with long dispersal capabilities (Carreras et al., 2020). Although genetic interchange occurs widely in P. lividus, the species is sensitive to dispersal barriers, displays isolation by distance and faces local selective pressures associated to environmental conditions, all of which can render it more vulnerable than previously thought.
\end{abstract}

Key words: Engineer species, Genotyping by sequencing, Oceanographic discontinuities, Outlier analysis, Sea urchin 
Acknowledgments: This work was supported by project PopCOmics (CTM2017-88080 MCIU, AEI/FEDER, UE). This is a contribution from SGR2017-1120.

\section{References:}

Carreras, C, García-Cisneros, A, Wangensteen, OS, et al. (2020). East is East and West is West: Population genomics and hierarchical analyses reveal genetic structure and adaptation footprints in the keystone species Paracentrotus lividus (Echinoidea). Diversity and Distributions 26, 382- 398. 


\title{
PHYSIOLOGICAL ROLES OF VERY LONG-CHAIN (>C24) FATTY ACIDS DURING EARLY DEVELOPMENT OF FISH: MOLECULAR AND FUNCTIONAL CHARACTERIZATION OF ELOVL4 GENES IN SPARUS AURATA AND SOLEA SENEGALENSIS
}

\author{
M. Torres ${ }^{1}$, S. Morais ${ }^{2}$, F. Hontoria ${ }^{1}$, Ó. Monroig ${ }^{1}$, I. Varó1 ${ }^{1}$ M.J. Agulleiro² and J.C. \\ Navarro ${ }^{1}$ \\ ${ }^{1}$ Instituto de Acuicultura de Torre de la Sal (IATS-CSIC), Ribera de Cabanes (Castellón), SPAIN. \\ miguel.torres.rodriguez@csic.es,hontoria@iats.csic.es,oscar.monroig@csic.es, \\ inma@iats.csic.es,jcnavarro@iats.csic.es. \\ ${ }^{2}$ Instituto de Investigación y Tecnología Agroalimentaria (IRTA), Sant Carles de la Rápita, \\ (Tarragona), SPAIN. \\ sofia.morais@lucta.com,mjagulleiro@gmail.com
}

\begin{abstract}
Very long-chain $\left(>\mathrm{C}_{24}\right)$ fatty acids (VLC-FA) play critical roles during early development of vertebrates, since these compounds are accumulated in the rapidly forming neural tissues, ensuring their normal function. However, despite their putative importance, the study of VLC-FA in fish is scarce. Biosynthesis of VLC-FA is carried out by the socalled elongation of very long-chain fatty acid 4 (Elov14) proteins and, consequently, the complement and function of these enzymes determine the capacity that a given species has for satisfying the physiological demands for VLC-FA, especially during its early development $[1,2]$. The present study aimed to characterize elovl4 genes from the marine teleosts Sparus aurata and Solea senegalensis, and determine the function of the corresponding encoded proteins. Moreover, the tissue expression pattern of elovl4 genes was determined. The results confirmed that both fish species possess two distinct Elovl4 proteins termed as Elovl4a and Elovl4b based on their homology to the zebrafish orthologs [3]. Functional assays in yeast denoted that both Elovl4a and Elovl4b from both species had the capability to elongate $\mathrm{C}_{20-24}$ fatty acid precursors to VLC-FA products. However, Elovl4b appeared to have a higher activity than Elovl4a elongating all the polyunsaturated fatty acid substrates assayed to longer chain polyunsaturated products, especially on the n3 series. Gene expression results indicated that, although elovl4 transcripts were detected in most tissues analyzed, elovl4 genes were more strongly expressed in both species neural tissues such as brain and eyes, which showed the highest expression levels of elovl4a and elovl $4 b$, respectively. These results are consistent with the functions of Elovl4 from other vertebrates. Importantly, these findings contribute to a better understanding of the VLCFA biosynthetic pathway in marine teleosts, highlighting the crucial role that Elovl4 products carry out for the correct development and maintenance of neurophysiologic functions during early stages of the fish development.
\end{abstract}


Key words: Sparus aurata, Solea senegalensis, very long-chain fatty acids, Elovl4, functional characterization.

Acknowledgments: This research was funded by the projects AGL 2013-40986-R (Spanish Government, Ministry of Economy and Competitiveness), and PROMETEO II / 2014/085 (Generalitat Valenciana). Miguel Torres was supported by a $\mathrm{PhD}$ funding program from Diputación de Castellón.

\section{References:}

[1] Deák, F., Anderson, R.E., Fessler, J.L. and Sherry, D.M. (2019). Novel cellular functions of very long chain-fatty acids : Insight from ELOVL4 mutations. Frontiers in Cellular Neuroscience, 13, 428.

[2] Torres, M., Navarro, J.C., Varó, I., Agulleiro, M.J., Morais, S., Monroig, Ó. and Hontoria, F. (2020). Expression of genes related to long-chain (C 18-22) and very long-chain ( $>\mathrm{C} 24)$ fatty acid biosynthesis in gilthead seabream (Sparus aurata) and Senegalese sole (Solea senegalensis) larvae: investigating early ontogeny and nutritional regulation. Aquaculture, 520, 734949.

[3] Monroig, Ó., Rotllant, J., Cerdá-Reverter, J.M., Dick, J.R., Figueras, A. and Tocher, D.R. (2010). Expression and role of Elovl4 elongases in biosynthesis of very long-chain fatty acids during zebrafish Danio rerio early embryonic development. Biochimica et Biophysica Acta (BBA)-Molecular and Cell Biology of Lipids, 1801(10), 1145-1154 


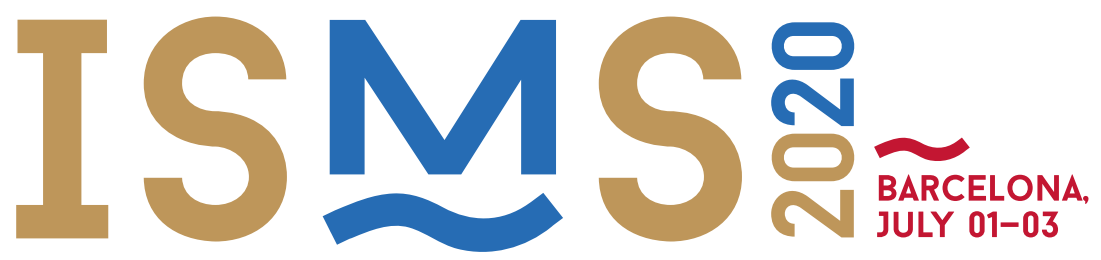

VII INTERNATIONAL SYMPOSIUM ON MARINE SCIENCES

\section{POSTER \\ COMMUNICATIONS}

\section{MODELLING IN MARINE SCIENCES}




\title{
PREDICTIVE MAPPING OF SEAGRASS COMMUNITIES ON THE MARESME INNER SHELF, BARCELONA
}

\author{
M. Canals ${ }^{1}$, D. Amblas ${ }^{1}$ X. Rayo ${ }^{1}$, J. Romero ${ }^{2}$ and J. Ylla ${ }^{3}$ \\ ${ }^{1}$ CRG Marine Geosciences, Dept. of Earth and Ocean Dynamics, Faculty of Earth Sciences, \\ University of Barcelona, 08029 Barcelona, SPAIN \\ miquelcanals@ub.edu,damblas@ub.edu,xrayos@ub.edu \\ ${ }^{2}$ RG Benthic Biology and Ecology, Department of Evolutionary \\ Biology, Ecology and Environmental Sciences, Faculty of Biology, University of Barcelona, \\ Barcelona, SPAIN \\ jromero@ub.edu \\ ${ }^{3}$ Directorate General for Fisheries and Maritime Affairs, Ministry of Agriculture, Livestock, \\ Fisheries and Food, Generalitat de Catalunya, Barcelona, SPAIN \\ joan.ylla@gencat.cat
}

\begin{abstract}
Seagrass communities occur on many inner shelves of the Mediterranean Sea, where they form meadows down to 40-45 m depth under optimal conditions. These communities play a key ecosystemic role and yield a number of services including water quality improvement, $\mathrm{CO}_{2}$ absorption, substrate fixation and production of sedimentary particles for beach nourishment. We report here the results of an investigation on the presence and distribution of seagrasses on the Maresme shelf, which extends along $50 \mathrm{~km}$ north of the city of Barcelona. Fieldwork mainly consisted of high-resolution multibeam bathymetry mapping during several years and in situ ground truthing by means of ROV video inspection in 2013 and 2014 and a GoPo drop-camera in summer 2017. Predictive maximum entropy modelling with the Maxent software has been carried out considering environmental predictors to produce habitat maps of seagrasses. We found that at present seagrasses mainly occur in the 10-20 m depth range of the central segment of the Maresme inner shelf, on a substrate made up of coarse sediments atop a relict morphology. Recurrent seafloor dredging for beach nourishment and other coastal interventions, together with event-driven river discharge, appear to be the main causative factors for a significant reduction of the potential depths and extension of seagrasses on the Maresme shelf. It would be worth investigating how the GLORIA major sea storm from 19 to 23 of January 2020 has impacted seagrass meadows along the Spanish Mediterranean shelf including the Maresme shelf.
\end{abstract}

Key words: Seagrasses, Posidonia oceanica, predictive habitat modelling, Maresme inner continental shelf, Mediterranean Sea 


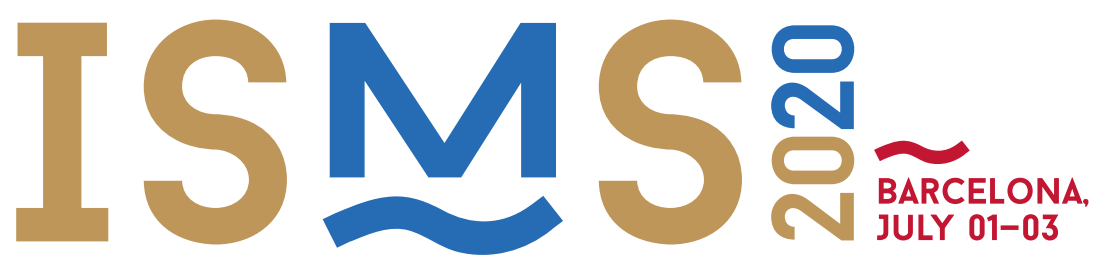

VII INTERNATIONAL SYMPOSIUM ON MARINE SCIENCES

\section{POSTER}

COMMUNICATIONS

\section{POLAR MARINE RESEARCH}




\title{
Key Environmental monitoring for Polar Latitudes and European Readiness (KEPLER)
}

\author{
C. Gabarro ${ }^{1 *}$, N. Huges ${ }^{3}$, J. Wilkinson ${ }^{2}$ and Kepler team \\ ${ }^{1}$ Institut de ciencies del Mar, ICM-CSIC, Barcelona Spain \\ ${ }^{2}$ MetNo, Norway \\ ${ }^{3}$ British Antartic Survey, URKI
}

\begin{abstract}
The large changes in Arctic and Antarctic climate, on land, in the ocean and in the atmosphere, are contributing to an 'opening up' of the Polar Regions that has important socio-economic, environmental and security implications. The Arctic Ocean will be increasingly accessible and more broadly used by those seeking its abundant resources and trade routes. Polar Regions remain a challenging operating environment with a harsh climate with sea ice and icebergs as a significant natural hazard that requires the need to; improve domain awareness, through EO services and products, to ensure the safe and efficient operations, including Search-and-Rescue, strong development of the predictive and monitoring capability for key climate indicators such sea ice extent and thickness, and further integration of the European Union's policy for the Arctic.
\end{abstract}

KEPLER is a multi-partner initiative, built around the operational European Ice Services and Copernicus information providers, to prepare a roadmap for Copernicus to deliver an improved European capacity for monitoring and forecasting the Polar Regions. Following the recommendations of the 'Copernicus User Uptake' review, KEPLER has 6 themes: 1) raising awareness for the Copernicus programme, 2) informing and educating Copernicus users, 3) engaging Copernicus users in public and private sector, 4) enabling access to Copernicus data and information, 5) identification of research gaps regarding integration/assimilation, and 6) improved sea-ice mapping and forecasting.

KEPLER aims to release the full potential of Polar Regions Earth Observation, including from ESA and EUMETSAT. Our objective with KEPLER is to enable the broad range of Polar Regions stakeholders to be equipped with the most accurate and relevant, environmental information so that they can seize the many benefits that Copernicus products generate for society and economy.

Key words: Polar regions, Copernicus, H2020 project

Acknowledgments: Thanks to EU and H2020 program 


\title{
CLIMATE CHANGE AND CHEMICAL ECOLOGY: DETERMINATION OF NATURAL PRODUCTS IN TWO SPECIES OF BRYOZOANS, HIMANTOZOUM (HIMANTOZOUM) ANTARCTICUM (CALVET, 1909) AND CHARTELLA TENELLA (HINCKS, 1887)
}

\author{
Sílvia Borrull* and Conxita Avila \\ BEECA Department (Invertebrates), Faculty of Biology and IrBIO, Barcelona, CATALONIA. \\ silvia.borrull.riera@gmail.com, conxita.avila@ub.edu
}

\begin{abstract}
The marine environment is exposed to global change and one of its effects is the increase of the water temperature, affecting all marine living species, even changing their metabolism. Many benthic organisms produce secondary metabolites (natural compounds) which are used as a defensive system against predation, competitors, microorganisms, pathogens, fouling, etc. In our study, our goal is to determine if there are variations in the natural product composition of two species of bryozoans when temperature is higher than usual. Therefore, two species of bryozoans were selected, representative of two different environments, Himantozoum (Himantozoum) antarcticum (Calvet, 1909) from Antarctica, and Chartella tenella (Hincks, 1887), from the Mediterranean Sea. The experiments consisted in keeping the animals at three different temperatures, $15^{\circ} \mathrm{C}, 20^{\circ} \mathrm{C}$, and $25^{\circ} \mathrm{C}$ for the species $C$. tenella, and $0^{\circ} \mathrm{C}, 5^{\circ} \mathrm{C}$, and $10^{\circ} \mathrm{C}$ for the species $H$. antarcticum. The experiments were done in filtered seawater aquaria, with a total of 40 organisms, 20 of each species for a total of two weeks for the Mediterranean samples and four weeks for the Antarctic samples. After organic extraction and clean-up of the samples, the determination of the different compounds was done using chromatography techniques coupled to ultraviolet-visible and a mass spectrometry detector (HPLC-MS). Chromatogram profiles show different composition between bryozoan extracts coming from the two environments, and samples kept at different temperatures present different chemical pattern, and therefore an effect of temperature on bryozoan natural products is observed.
\end{abstract}

Key words: Marine benthos, Natural products, Antarctica, Mediterranean Sea.

Acknowledgments: This study has been developed within the frame of the BLUEBIO project (CTM2016-78901/ANT). Thanks are also due to C. Angulo-Preckler and P. De Castro for their support along this research. This is an AntEco (SCAR) contribution. 


\title{
SIGNS OF VOLCANIC ERUPTIONS IN AN ANTARCTIC MARINE BENTHIC INVERTEBRATE Montserrat Cruz*1, Adelina Geyer ${ }^{2}$, Carlos Angulo-Preckler ${ }^{1}$, and Conxita Avila ${ }^{1}$ \\ ${ }^{1}$ BEECA Department (Invertebrates), Faculty of Biology and IrBIO, Barcelona, CATALONIA. mcruzfra13@alumnes.ub.edu, carlospreckler@hotmail.com,conxita.avila@ub.edu \\ ${ }^{2}$ Institute of Earth Sciences "Jaume Almera”, ICTJA-CSIC, Barcelona, CATALONIA. ageyer@ictja.csic.es
}

\begin{abstract}
The ability of some aquatic invertebrates to take up and accumulate trace elements has recently provided interesting results. The analysis of accumulated metal concentrations has numerous applications in the fields of biomonitoring programmes, but they can also be interesting for monitoring active volcanic areas and reconstructing past eruptive events. In this study, we analyzed the Antarctic limpet Nacella concinna (Strebel 1908), the most conspicuous benthic macroinvertebrate of the intertidal zone of the Antarctic Peninsula and adjacent islands. Samples were collected in Port Foster, a sea-flooded bay located in the interior of Deception Island, one of the most active volcanoes in Antarctica. The historical volcanic activity and the recent eruptions (1967, 1969, and 1970), together with the unrest episodes of 1992, 1999, and 2014-2015, categorize Deception Island as a very active volcano. The objective of this study is to evaluate whether $\mathrm{Mg} / \mathrm{Ca}$ and $\mathrm{Sr} / \mathrm{Ca}$ ratios measured in the shell's annual bands of the limpet $N$. concinna are reliable proxies for environmental variations, especially for those caused by volcanic activity. The combination of images obtained with optical and electronic microscope, including cathodoluminescence, allowed us to visualize and count the growth bands of the shell, and thus to determine, together with their size, the age of the limpets. We conclude that the $\mathrm{Mg} / \mathrm{Ca}$ and $\mathrm{Sr} / \mathrm{Ca}$ elemental ratios are not temperature-dependent, but other variables may instead influence them, and the shells do not register the volcanic activity on Deception Island.
\end{abstract}

Key words: Marine benthos, Deception Island, Nacella concinna, cathodoluminescence, growth bands.

Acknowledgments: This study has been developed within the frame of the BLUEBIO (CTM2016-78901/ANT) and VOLGASDEC (PGC2018-095693-B-I00) projects. Thanks are also due to the ICTJA-CSIC and CCiT-UB technical staff, particularly Dr. Xavier Llovet for his help along this research. This is an AntEco and AntVolc (SCAR) contribution. 

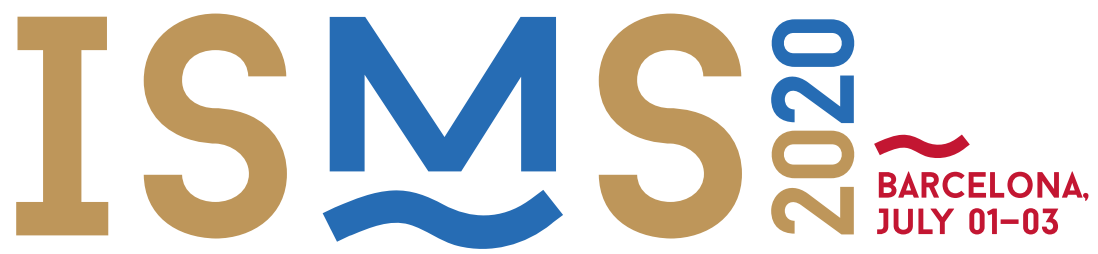

VII INTERNATIONAL SYMPOSIUM ON MARINE SCIENCES

\section{POSTER \\ COMMUNICATIONS}

\section{TECHNOLOGIES AND DATA MANAGEMENT}




\title{
EFFICIENT COMPRESSION OF MULTIBEAM ECHOSOUNDERS WATER COLUMN DATA
}

\author{
David Amblas*1, Jordi Portell ${ }^{2}$ and Galderic Lastras ${ }^{1}$ \\ ${ }^{1}$ CRG Marine Geosciences, Dept. of Earth and Ocean Dynamics, University of Barcelona, \\ Barcelona, SPAIN.damblas@ub.edu,glastras@ub.edu \\ ${ }^{2}$ Dept. FQA, Institute of Cosmos Sciences (ICCUB), University of Barcelona (IEEC-UB), \\ Barcelona, SPAIN and DAPCOM Data Services, Castelldefels, SPAIN.jordi.portell@dapcom.es
}

\begin{abstract}
:
Multibeam echosounders allow to collect water column acoustic images (Colbo et al., 2014), which leads to vast amounts of data. Existing compression algorithms provide poor ratios at high computing costs. Here we present a new data compression solution (Portell et al., 2019) inherited from the Gaia space astrometry mission. FAPEC is a highly optimized, application-specific and versatile data compression system (Portell et al., 2018). We have adapted it to Kongsberg MBES water column data, providing lossless and lossy compression with different quality levels. The lossy mode uses a non-biased quantization of backscatter data samples, reducing the number of grey shades in the reconstructed image but keeping the full image resolution. It allows detecting fish shoals, gas seeps or sunken structures, for example. This is a fully operational solution providing block-based operation, multi-threading and encryption. Its ANSI C implementation makes it portable, including ARM-based computing platforms such as those present in AUVs. Its tiny code footprint and memory requirements makes it compatible with microcontrollers. We have tested FAPEC on Kongsberg EM302, EM710 and EM2040 water column files, collected inside the harbour of Barcelona (with structural elements and shoaling fish) and in the Gulf of Mexico (at depths around $1000 \mathrm{~m}$, presenting gas seeps). We compare the results with those from gzip, bzip2, 7-zip and Zstandard. Lossy FAPEC compression has been tested with 128 to 8 shades of grey. We achieve the best lossless compression ratios on all cases. Lossy compression can lead to data volumes even smaller than raw bathymetry files. Besides, FAPEC is fast, exceeding $60 \mathrm{MB} / \mathrm{s}$ (three times faster than gzip) even in single-thread mode on a typical desktop computer. Continuous water column acquisition is now feasible with FAPEC, even on slow processors.
\end{abstract}

Key words: Multibeam echosounders, water column, data compression, lossless, lossy.

Acknowledgments: This project has received funding from the European Union's Horizon 2020 research and innovation programme under the Marie Sklodowska-Curie grant agreement No 658358 (D. Amblas) and MICINU (Spain) through RTI2018-095076-B-C21.

\section{References:}

Colbo, K., Ross, T., Brown, C., Weber, T. (2014). A review of oceanographic applications of water column data from multibeam echosounders. Estuarine, Coastal Shelf Science 145, 41-56.

Portell, J., Amblas, D., Mitchell, G., Morales, M., Villafranca, A.G., Iudica, R., Lastras, G. (2019). HighPerformance Compression of Multibeam Echosounders Water Column Data. IEEE Journal of Selected Topics in Applied Earth Observations and Remote Sensing 12(6), 1771-1783. 
Portell, J., Iudica, R., García-Berro, E., Villafranca, A.G. and Artigues, G. (2018). FAPEC, a versatile and efficient data compressor for space missions. International Journal of Remote Sensing 39(7), 2022-2042. 


\title{
CORRELATION STUDY BETWEEN WAVE BUOYS AND SIMAR DATA IN THE CANARY ISLANDS
}

\author{
Itziar Rubio-Astorga ${ }^{1}$, Mariona Casamayor ${ }^{2}$ and Ignacio Alonso*3 \\ ${ }^{1}$ Facultad de Ciencias del Mar, Universidad de Las Palmas de Gran Canaria, Las Palmas de Gran \\ Canaria, Spain. \\ itziar.rubio101@alu.ulpgc.es \\ ${ }^{2,3}$ Instituto de Oceanografía y Cambio Global, Universidad de Las Palmas de Gran Canaria, Las \\ Palmas de Gran Canaria, Spain. \\ marionacasamayor@gmail.com; ignacio.alonso.bilbao@ulpgc.es
}

\begin{abstract}
A large amount of data is currently available to study the waves conditions in a wide part of the world. In Spain, both wave data recorded at buoys and wave data from hindcast SIMAR model can be obtained from Puertos del Estado. The aim of this study is to analyse the correlation between both wave data sources. Four buoys have been selected in Tenerife and Gran Canaria, two in each island, exposed to different wave conditions. Data from each buoy have been correlated with the closest SIMAR point, located, in any case, within $2 \mathrm{~km}$ of distance. Correlation period ranges from 10 to 28 years at the different locations. However, only the valid values recorded in both data sets have been used. The wave parameters analysed are significant wave height (Hs), peak period and direction.

Results show that Hs values from SIMAR data are lower than their corresponding buoy data in Tenerife, while at Gran Canaria the agreement is better. These differences are $22 \mathrm{~cm}$ and $39 \mathrm{~cm}$ at Santa Cruz and Tenerife Sur respectively. Nevertheless, Hs is the parameter that shows the best correlations, ranging from 0.92 at Las Palmas Este to 0.66 at Tenerife Sur. Same pattern takes place when referring to peak period, since values in Gran Canaria are much better correlated than those in Tenerife, ranging from 0.12 at Tenerife Sur to 0.62 at Gran Canaria Norte. Regarding directions, correlation coefficients are always higher than 0.56. Las Palmas Este is the location which shows the best result, with a value of 0.79 . The southern boundary of the WAM model in which SIMAR data are based is very close to the south of the islands. Since both buoys in Tenerife are mostly exposed to southern waves, data obtained there are less reliable (Puertos del Estado, 2020). In conclusion buoys in Gran Canaria are better correlated to SIMAR data than those in Tenerife.
\end{abstract}

Key words: SIMAR, wave data, statistical analysis.

Acknowledgments: We want to acknowledge to Puertos del Estado for providing the data used in this study.

\section{References:}

Puertos del Estado (2020). Conjunto de datos SIMAR. Technical report. 


\title{
ANNUAL TO DECADAL VARIABILITY PATTERNS OF HIGH NUTRIENT LOW CHLOROPHYLL REGIONS: A REMOTE SENSING PERSPECTIVE
}

\author{
Font-Muñoz J.S. *1 Basterretxea G. ${ }^{2}$, Hernandez-Carrasco $I^{2}$. and S. Sañudo- \\ Wilhelmy ${ }^{3}$
}

${ }^{1}$ Université de Brest - UBO/CNRS/IFREMER/IRD, 29238, Brest, France jsfontmu@ifremer.fr

${ }^{2}$ Instituto Mediterráneo de Estudios Avanzados, IMEDEA (UIB-CSIC), Miquel Marqués 21, 07190 Esporles, Illes Balears, Spain.

${ }^{3}$ Department of Biological Sciences and Department of Earth Sciences, University of Southern California, Marine Biology and Biological Oceanography, Los Angeles, California 90089-0371, United States

\begin{abstract}
:
The spatial and temporal dynamics of ocean biomes are affected by the dynamics of Earth's climate system and understanding their response to ongoing change is of primary importance. We use 20-years of monthly global ocean color data and modelling outputs of nutrients to identify characteristic spatial and temporal patterns of High Nutrient Low Chlorophyll regions (HNLC). A neural network classification, based on the Self-Organizing Maps (SOM) analysis in the time and spatial domain, is used to reveal regions of similar temporal and spatial variability of the global nitrate to chlorophyll ratio (NO3:Chl). Analyzing the statistical behavior in the probability distribution function of the global nitrate to chlorophyll ratio (NO3:Chl), we estimate that $\mathrm{NO} 3: \mathrm{Chl}>17(\mu \mathrm{mol} \mathrm{NO} 3 / \mu \mathrm{g} \mathrm{Chl})$ is a good indicator of the distribution limit of this biome that extends over $\sim 25 \%$ of the ocean comprising three well known regions or subsystems; the Subarctic North Pacific (SNP), the Eastern Equatorial Pacific (EEP) and the Southern Ocean (SO). Trends in chlorophyll indicate that HNLC regions in polar and subpolar areas have experienced an increase in the surface chlorophyll over the last decades $\left(0.6\right.$ to $\left.2 \% \mathrm{yr}^{-1}\right)$. The relationship of these variations with that of three major climate variability signals (Sea Surface Temperature, SST; El Niño Southern Oscillation, ENSO; and Meridional Overturning Circulation, MOC) reveals strong annual and semiannual variability that is coherent with seasonal temperature variations. However, on larger time - scales, ENSO driven variability and decadal scale processes of heat uptake and redistribution, as revealed by MOC variations, influence HNLC extension. Our results are indicative of the long-term changes occurring in the ecological functioning of the marine ecosystem suggesting a narrow global scale atmosphere-ocean coupling with impact on ocean productivity.
\end{abstract}


Key words: chlorophyll, nitrate, HNLC, long-term variations, remote sensing, selforganizing maps

Acknowledgments: This work was partially founded by MINECO SIFOMED grant (CTM2017-83774-P). G. Basterretxea was supported by Salvador de Madariaga PRX18/00056 scholarship. J.S. Font-Muñoz was supported by the French National Research Agency under the ISblue program (ANR-17-EURE-0015). We are grateful to GlobColour, NOAA, CARINA, GEOTRACES, COPERNICUS and NERC for freely available data. 


\title{
IMPACTS OF OFFSHORE WIND FARMS ON COASTAL TOURISM ACTIVITIES IN IRELAND
}

\author{
J. Terra Miranda*1, M. de Andrés ${ }^{2}$ and C. Valerie ${ }^{3}$ \\ ${ }^{1}$ Marine and Environmental Sciences, Universidad de Cádiz, Cádiz, Spain. \\ juliatmachado@gmail.com \\ ${ }^{2}$ History, Geography and Philosophy Department, Universidad de Cádiz, Cádiz, Spain \\ maria.deandres@uca.es \\ ${ }^{3}$ School of Biological, Earth and Environmental Sciences, University College Cork, Cork, Ireland. \\ v.cummins@ucc.ie
}

\begin{abstract}
:
Offshore wind sector installed $4.5 \mathrm{GW}$ in 2018, reaching cumulative $23 \mathrm{GW}$ globally. Ireland, a country famous for its natural sites, has been called as an Offshore wind upcoming market, fuelled by the introduction of new technologies and the declining cost. However, along with this expansion, concerns about related visual impacts and marine spatial use grow, especially when other important coastal-marine sectors, as Tourism and Recreation, compete for the area occupied by the wind farms. Because of the importance of both sectors in Ireland's economy and development, their interaction needs to be analysed in detail, aiming a better understanding on how the tourism sector benefits or jeopardizes from offshore wind operations. Therefore, a thorough literature review with international papers from the past 5 years and a landscape analysis on the chosen windfarm area, Wicklow park, based on European and Irish governmental GIS data, about both sectors have been done. As a result, analysed literature shows that a big knowledge gap exists and most papers suggest that, overall, there is no evidence to suggest a serious negative economic impact of wind farms on tourism. Nevertheless, changes are observed, but most produced reports target general perceptions and tourists per accommodation data, not focusing on the sensibility to turbines in the landscape or on the local inhabitants' perceptions or in the tourists' response to existing or potential turbines presence. In addition, the GIS analysis builds an impact zone and reveals possible impacts with their relative weight, according to distance from the beach and type of interaction between the landscape with the turbines and the studied coastal-marine activities Tourism and Recreation activities. In conclusion, the interaction between these sectors should be deeper evaluated and a more specific regulation should be implemented as part of the Implementation Environmental Assessment for Offshore wind farm developments.
\end{abstract}

Key words: Offshore wind energy, Coastal Tourism, Renewable energy, MSP, SDGoal 7

Acknowledgments: European Union through the Erasmus Mundus Programme for giving me the opportunity of developing my master studies in Water and Coastal Management and my thesis supported by their scholarship, granted after the 2018-2020 call selection process. 


\section{References:}

The Department of the Environment Heritage and Local Government, Ireland, S. E., Pleanála, A. B.,

Council., C. C., Ireland., G. S. of, Authority, I. A., \& Farrell, D. E. R. (2017). National Renewable Energy Action Plan - Fourth Progress Report. December, 1-67. https://www.dccae.gov.ie/documents/NREAP Fourth Progress Report.pdf

Wind, G., \& Council, E. (2019). Global wind report 2018. 

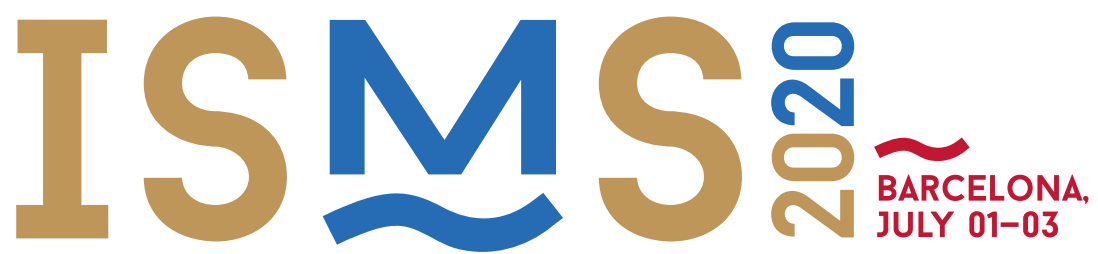

VII INTERNATIONAL SYMPOSIUM ON MARINE SCIENCES

\section{POSTER COMMUNICATIONS}

\section{THE PHYSICAL BASES OF MARINE SCIENCES}




\title{
ECCO: A NEW APPROACH TO ESTIMATE THE TIME VARIABILITY OF THE MERIDIONAL OVERTURNING CIRCULATION IN THE SOUTH ATLANTIC AT 30 -S
}

\author{
C. Arumí-Planas ${ }^{1}$, M. Casanova-Masjoan ${ }^{1}$ and A. Hernández-Guerra ${ }^{1}$ \\ ${ }^{1}$ Unidad Océano y Clima, Instituto de Oceanografía y Cambio Global, IOCAG, Universidad de Las \\ Palmas de Gran Canaria, ULPGC, Unidad Asociada ULPGC-CSIC, Canary Islands, Spain.
}

\begin{abstract}
Time series of mass transport for the upper, deep and abyssal layers in the Atlantic Ocean at $30^{\circ} \mathrm{S}$ have been estimated using data obtained from the ECCOv4r3, a model developed by the Jet Propulsion Laboratory under a contract with the NASA. These estimations have been compared with analogous data obtained from the GO-SHIP hydrographic transoceanic sections at 305 from 1993, 2003 and 2011. Results show that the ECCOv4r3 solution for the upper layers $\left(\gamma^{n}<27.58 \mathrm{~kg} / \mathrm{m}^{3}\right)$ is not significantly different from the mass transports estimated by the hydrographic data. This is not the case, however, for the deep and abyssal layers $\left(\gamma^{n}>27.58 \mathrm{~kg} / \mathrm{m}^{3}\right)$, where noticeable differences are found. The ECCOv4r3 points out that the Brazil Current shows a seasonal variability with higher mass transport from August to March (-15.8 $\pm 0.7 \mathrm{~Sv}$ ) than from April to July ($13.3 \pm 0.4 \mathrm{~Sv})$. Furthermore, the ECCOv4r3 indicates that the Benguela Current shows a seasonal variability with higher mass transport from June to November $(13.8 \pm 0.3 \mathrm{~Sv})$ than from December to May (13.1 $\pm 0.2 \mathrm{~Sv})$. The comparison of heat transport and freshwater flux estimated with ECCOv4r3 to those obtained from hydrographic data show no significant differences. Nevertheless, the freshwater flux estimated by hydrographic data suggest that it has been decreasing during the study period, while the same estimation with ECCOv4r3 data do not show any decrease. The overturning stream-function estimated with ECCOv4r3 is not significantly different than the AMOC estimated by hydrographic data for the thermocline and intermediate layers. The ECCOv4r3 reveals that the AMOC shows a seasonal variability with stronger mass transport from April to September (16.6 $\pm 0.9 \mathrm{~Sv}$ ) than from October to March (14.5 $\pm 0.2 \mathrm{~Sv}$ ).
\end{abstract}

Key words: ECCO, AMOC, South-Atlantic. 


\title{
The Canary Eddy Corridor: Lagrangian Evolution of two Anticyclonic Eddies based on Altimetry and Model Data
}

\author{
José Luis García-García *1,2, Borja Aguiar-González ${ }^{1}$ and Ángel Rodríguez- \\ Santana ${ }^{1}$ \\ ${ }^{1}$ OFYGA. Departamento de Física, Universidad de Las Palmas de Gran Canaria, Las Palmas de \\ Gran Canaria, SPAIN. \\ ${ }^{2}$ Facultad de Ciencias del Mar y Ambientales, Universidad de Cádiz, Cádiz, SPAIN. \\ joseluis.garciagarcia@alum.uca.es,borja.aguiar@ulpgc.es,angel.santana@ulpgc.es
}

Abstract: The Canary Eddy Corridor $\left(22.1^{\circ}-29.1^{\circ} \mathrm{N}\right)$ is a zonally long-lived mesoscale eddy pathway of the Northeastern subtropical Atlantic Ocean. The Canary Eddy corridor was firstly described in Sangrà et al (2009), where the authors report this corridor constitutes a direct zonal pathway of westward transport for water mass and biogeochemical properties, from the Canary Islands/Northwest Africa upwelling system to the oligotrophic ocean interior.

In this study we investigate the Lagrangian evolution of two anticyclonic eddies of the Canary Eddy Corridor (Sangrà et al, 2009) combining altimeter-derived eddy tracking properties and model data. Based on these combined datasets, we provide first estimates of eddy-driven ocean properties and associated fluxes. Lastly, we test further our results against in situ hydrographic measurements from two interdisciplinary surveys sampling the same anticyclonic eddies. Preliminary results show good agreement of the time-evolving geometric properties and associated fluxes derived from observations and model data.

Key words: Northeastern Subtropical Atlantic, Canary Eddy Corridor, Eddy Tracking, Lagrangian Evolution

Acknowledgments: This work has been supported by the Spanish government (Ministerio de Economía y Competitividad) through project FLUXES (CTM2015-69392- C3-3- R)

\section{References:}

Sangrà P., Pascual A., Rodríguez-Santana A., Machín F., Mason E., McWiliams J. C., Pelegrí J. L., Dong C., Rubio A., Arístegui J., Marrero-Díaz A., Hernández-Guerra A., Martínez-Marrero A., Auladell M. (2009). The Canary Eddy Corridor: A major pathway for long-lived eddies in the subtropical North Atlantic. Deep Sea Research I, 56, 2100-2114. 


\title{
SPATIO-TEMPORAL VARIABILITY OF THE BRANSFIELD CURRENT SYSTEM (ANTARCTICA) BASED ON DIRECT VELOCITY MEASUREMENTS
}

\author{
Marta Veny*1, Borja Aguiar-González ${ }^{1}$ and Ángeles Marrero-Díaz ${ }^{1}$ \\ ${ }^{1}$ Grupo de Investigación en Oceanografía Física y Geofísica Aplicada (OFYGA), Departamento de \\ Física, Universidad de Las Palmas de Gran Canaria, Las Palmas de GC, SPAIN. \\ marta.veny101@alu.ulpgc.es*, borja.aguiar@ulpgc.es, angeles.marrero@ulpgc.es
}

\begin{abstract}
The Bransfield Strait is a semi enclosed region located between the Antarctic Peninsula and the South Shetland Islands (SSI), where the most distinctive feature of the circulation is a baroclinic jet flowing north-eastward along the southern slope of the SSI, the Bransfield Current (BC; Niller et al., 1991). Recent studies have shown that the BC propagates as a buoyant gravity current, recirculating around the north-eastern tip of the islands while shedding an anticyclonic eddy (Sangrà et al., 2011, 2017). However, most previous works are based on summertime measurements and a more comprehensive spatio-temporal view of the regional circulation is still lacking to further understand the governing shelf dynamics.

In this study we provide the first year-round description of the Bransfield Current System around the SSI based on an extensive dataset of direct velocity measurements. These measurements were routinely collected along ship tracks from 275 cruises between 1999 and 2014. Preliminary results suggest as a main finding that the $\mathrm{BC}$ is a permanent feature of the current system, which persists through winter.
\end{abstract}

Key words: South Shetland Islands, Bransfield Current System, Spatio-Temporal Variability, Direct Velocity Measurements

Acknowledgments: This work has been supported by the Spanish government (Ministerio de Economía y Competitividad) through project FLUXES (CTM2015-69392- C3-3- R).

\section{References:}

Niller, P. P., Amos, A., \& Hu, J. H. (1991). Water masses and $200 \mathrm{~m}$ relative geostrophic circulation in the western Bransfield Strait region. Deep Sea Research Part A. Oceanographic Research Papers, 38(8-9), 943959.

Sangrà, P., Gordo, C., Hernández-Arencibia, M., Marrero-Díaz, A., Rodríguez-Santana, A., Stegner, A., ... \& Pichon, T. (2011). The Bransfield current system. Deep Sea Research Part I: Oceanographic Research Papers, 58(4), 390-402.

Sangrà, P., Stegner, A., Hernández-Arencibia, M., Marrero-Díaz, Á., Salinas, C., Aguiar-González, B., ... \& Mouriño-Carballido, B. (2017). The Bransfield gravity current. Deep Sea Research Part I: Oceanographic 


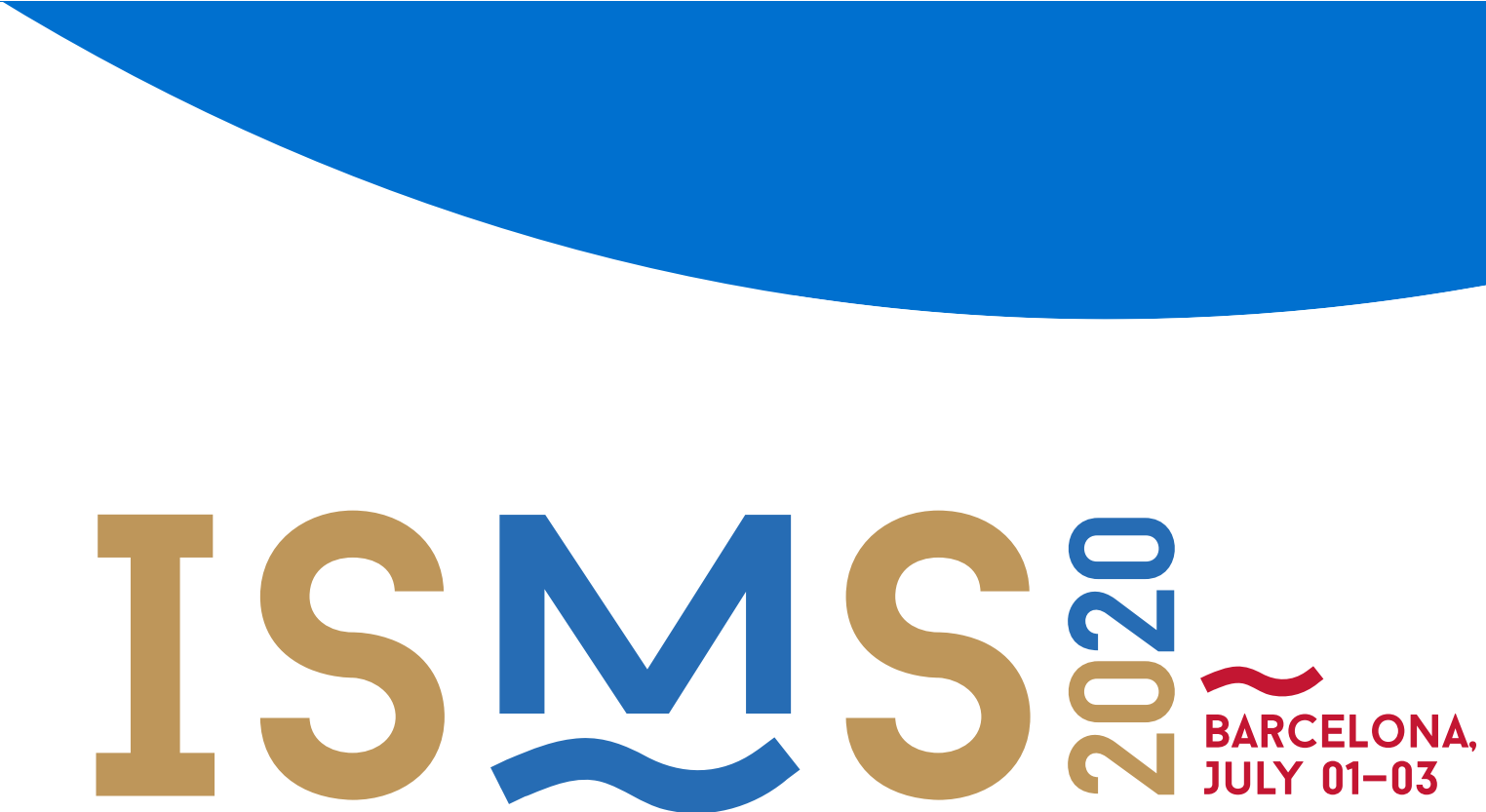

VII INTERNATIONAL SYMPOSIUM ON MARINE SCIENCES

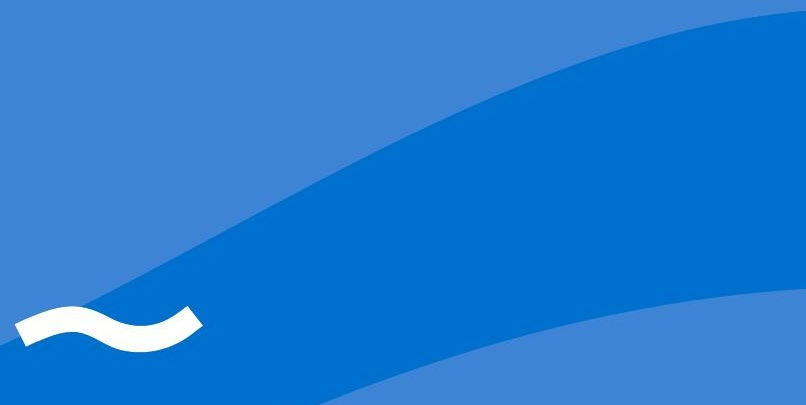

WWW.ISMS.CAT

ORGANIZERS

\section{UNIVERSTAT IIIIIII BARCELONA}

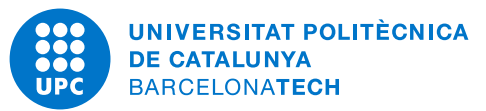

Universida $\mathrm{de}^{\text {Vigo }}$

$\triangleq \begin{aligned} & \text { Universitat d'Alacant } \\ & \text { Universidad de Alicante }\end{aligned}$

Universidad de

Las Palmas de Gran Canaria
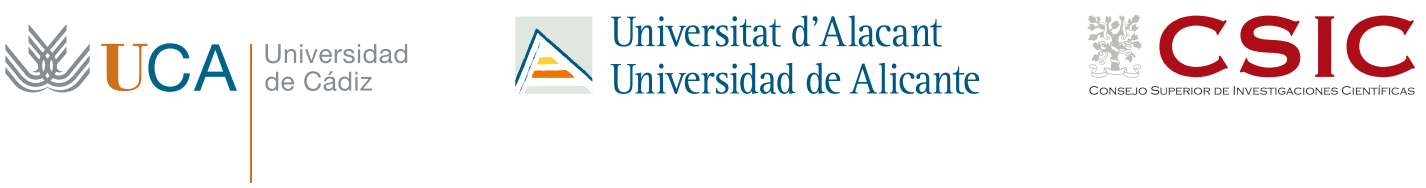

WITH THE ENDORSEMENT OF

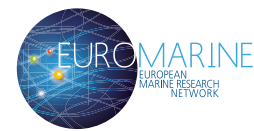

nat museu de ciències naturals

de Barcelona
COLLABORATE

SIBECOL

Sociedad Ibérica Ecología 